


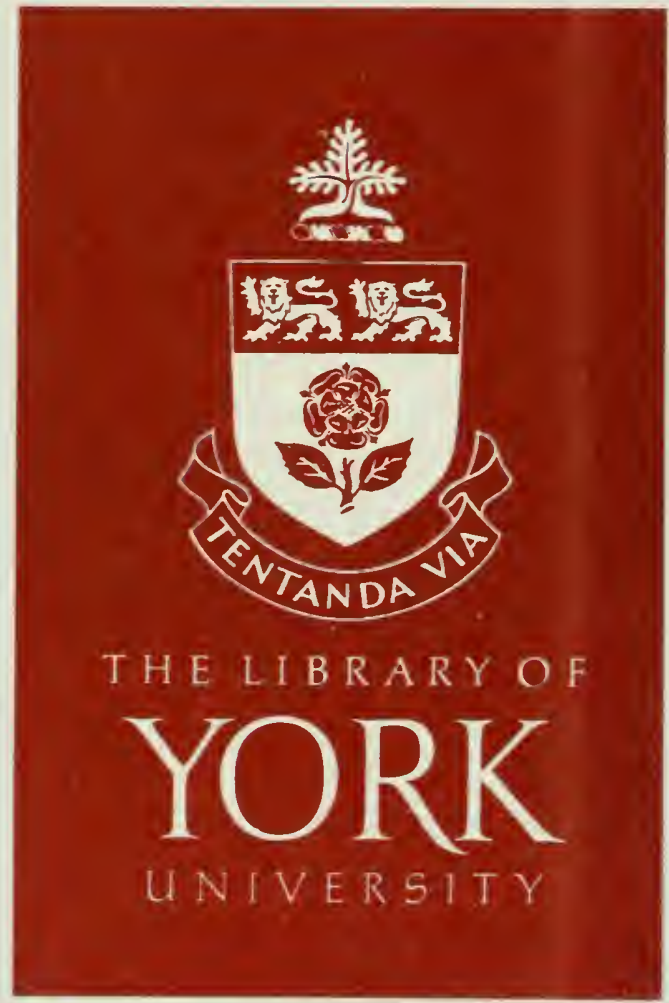





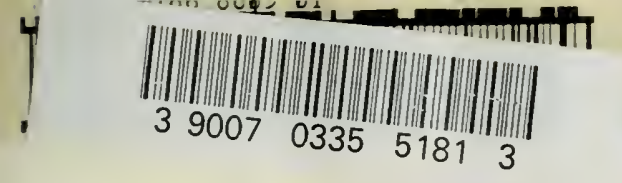

\section{Date Due}

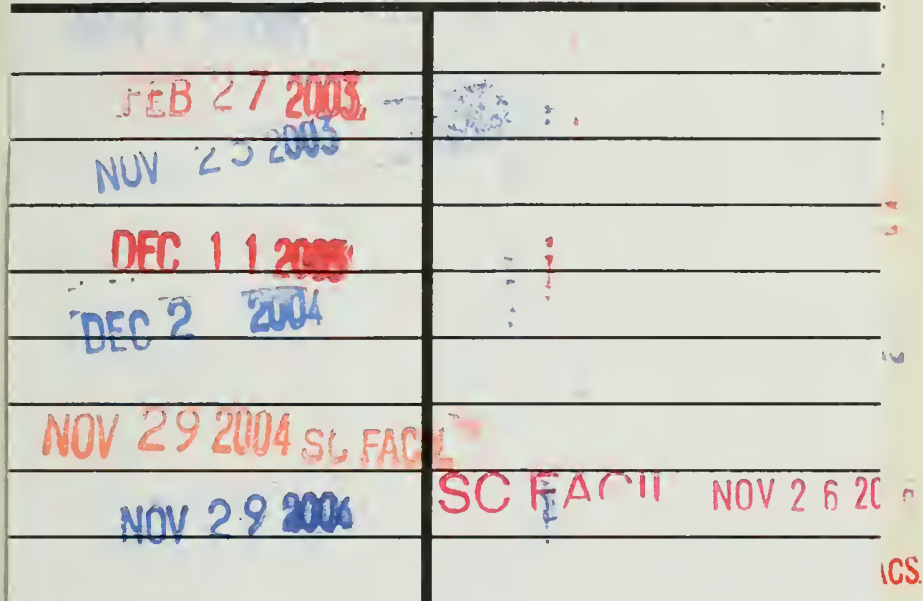



Digitized by the Internet Archive in 2009 with funding from Ontario Council of University Libraries 



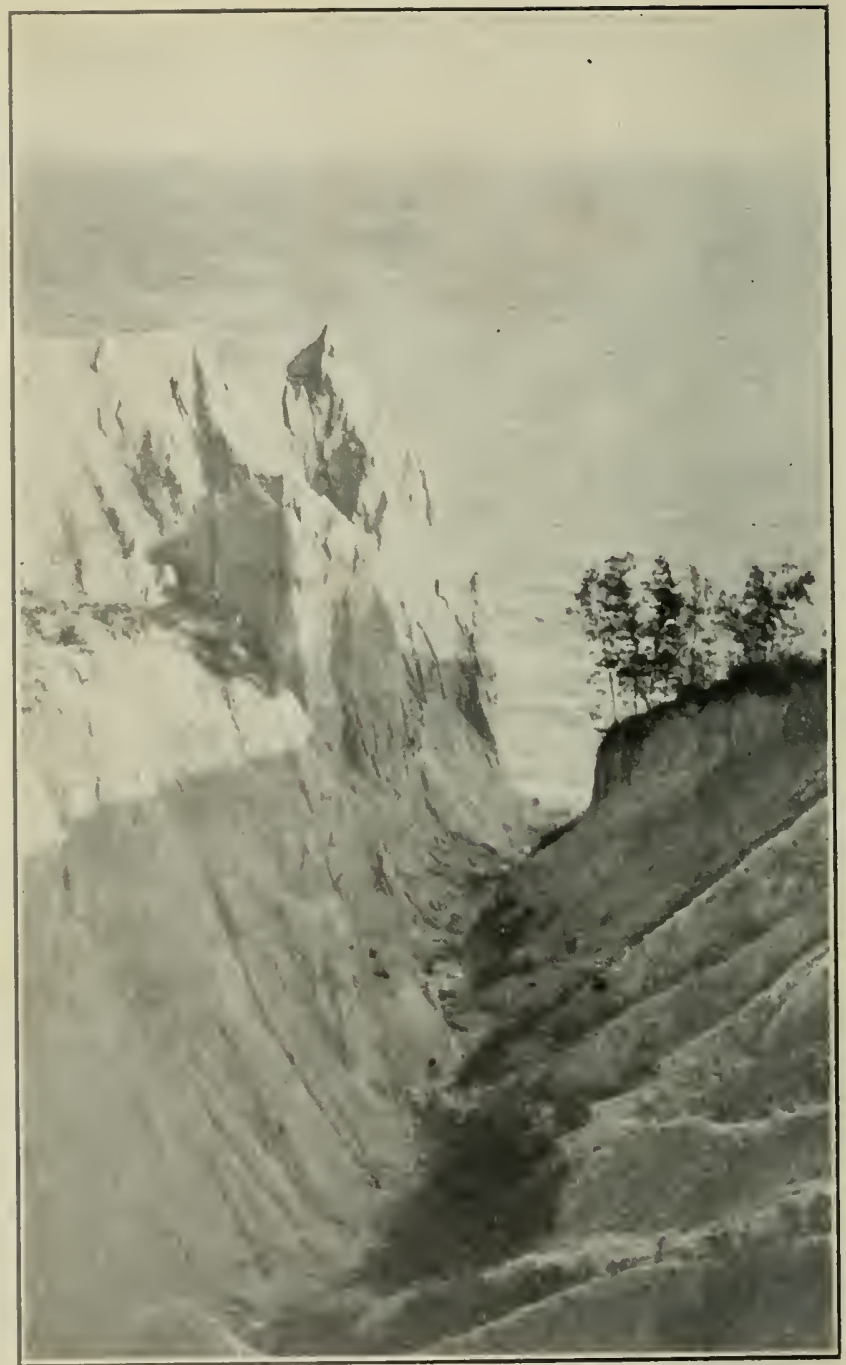

"DUTCH CHURCH," SCARBOROUGH HEIGHTS.

l'hoto by $\Lambda$, l'. Coleman. 


\title{
The Natural History of
} the Toronto Region

ONTARIO, CANADA

\author{
EDITED BY \\ J H. FAULL, B.A., Рн.D.
}

Associate Professor of Botany, University of Toronto

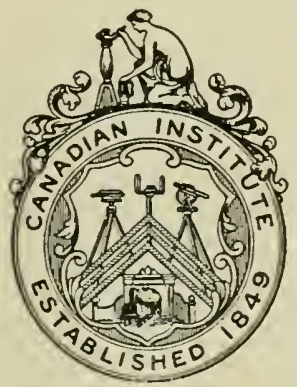

TORONTO

PUBLISHED BY THE CANADIAN INSTITUTE 1913 
Copyright, Canada, 1913, by

J. H. FAULL

PRINTED BY

WILLIAM BRIGGS

TORONTO 


\section{THE GANADIAN INSTITUTE.}

\section{Officers for 1913-1914.}

President - - - Frank ArNoldi, K.C.

1st Vice-President - - Professor J. C. McLennan, Ph.D.

2nd Vice-President - J. M. Clark, K.C.

Hon. Secretary - - J. Patterson, M.A.

Hon. Treasurer - - Williair Scott, M.A.

Hon. Librarian - - Professok D. R. Kers, M.A.

Hon. Curator - - - J. B. Willialis, Esq.

Editor, - - - - George Kennedy, M.A., LL.D.

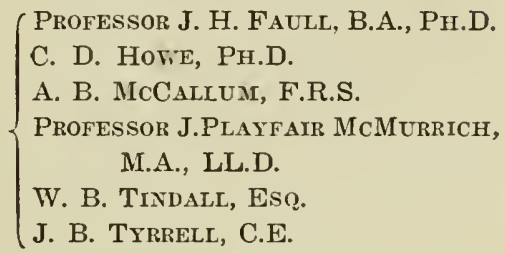

Committee for Publication of this Book.

A. P. Coleman, Ph.D., F.R.S.

J. H. Faull, B.A., Ph.D.

A. B. McCallum, F.R.S.

Williain Scott, M.A.

R. F. Stupart, F.R.S.C.

J. B. Tyrrell, C.E.

E. M. WALKER, B.A., M.B.

J. B. Willianis, EsQ.

The Aims and Objects of the Canadian Institute.

1. The dissemination of useful knowledge by means of a course of popular lectures free to the public.

2. The fostering of public interest in science, art and discovery.

3. The publication of original scientific contributions in the form of the Transactions of the Canadian Institute.

4. The maintenance of a valuable research library of the transactions of learned societies through the medium of the exchange of publications. 



\section{PREFA CE}

THIs work has been prepared by the Canadian Institute for the members of the Twelfth Geological Congress and for all who may have an interest in the history and natural history of the city and vicinity. The articles have been generously contributed by specialists in their respective fields, and represent more than mere compilations. The maps and illustrations have either been prepared for this book or are reproduced here from original sources by permission. Credit is given in connection with each. To the contributors, the publishers, and to the many friends who have so freely aided with information or advice, the members of the publication committee desire to express their sincere indebtedness.

$$
\begin{aligned}
& \text { J. B. Tyrrell, President. } \\
& \text { J. H. Faull, Editor. }
\end{aligned}
$$





\section{CONTENTS}

CHAPTER

PAGE

I. Toronto : An Historical and Descriptive Sкетсн. By David Reid Keys, M.A. - 11

II. The Indians who formerly Inhabited or Visited the Site of Toronto. By Alexander Francis Chamberlain, M.A., Ph.D. - - - - - - - 44

III. Geology of the Toronto Region. By A. P. Coleman, Ph.D., F.R.S. - - 51

IV. The Climate of Toronto. By R. F. Stupart, F.R.S.C. - - - - - 82

V. Life Zones, By C. D. Howe, Ph.D. - 91

VI. The Seed Plants of Toronto and Vicinity. By Principal William Scott - - $\quad 100$

VII. Ferns and Fern Allies. By T. J. Ivey, M.A. - $\quad$ - $\quad$ - $\quad$ - $\quad$ - $\quad$ - $\quad$ - 141

VIII. Mosses and Liverworts. By G.H. Graham, M.A. - $\quad$ - $\quad$ - $\quad-\quad$ - $\quad$ - $\quad$ - 150

IX. Mushrooms and Other Fungi. By Thomas Langton, M.A., LL.B. - - 158

X. The Algae. By J. H. Faull, Ph.D. - 174 XI. Lichens. By J. H. Faull, Ph.D. - - 180 


\section{CONTENTS}

CHAPTER

XiI. Mrcetozoa, or Slise Moulds. By J. H. Faull, Ph.D. - $\quad$ - $\quad$ - $\quad$ - $\quad$ - $\quad$ - 188

XIII. Ixsect Galls of the Vicinity of Toronto.

By A. Cosens, M.A., Ph.D. - - - 193

XIV. Zoology. Edited by J. Playfair McMurrich 205

XV. Mammals. By James H. Fleming - . 206

XVI. Birds. By James H. Fleming - - - 212

XVII. Reptiles. By J. B. Williams, F.Z.S. - 238

XVIII. Amphibia. By W. H. Piersol, B.A., M.B. 242

XIX. Fishes. By C. W. Nash - - - - 249

XX. Invertebrates other than Insects aNd

Mollusks. By A. G. Huntsman, B.A.,

M.B. - - - - - - - 272

XXI. Mollusca. By A. D. Robertson, B.A. - 288

XXII. Insects and their Allies. By E. M.

Walker, B.A., M.B. - $\quad$ - $\quad$ - $\quad$ - 295

XXIII. Excursions 


\section{ILLUSTRATIONS AND MAPS.}

PAGE

"Dutch Church," Scarborough Heights Frontispiece

Map of Toronto and Vicinity - $\quad$ - $\quad$ - $\quad$ - $\quad$ - 51

Edge of Escarpment at Hamilton - - - 61

Fossil Leaves (Interglacial), Don Valley _ - 71

Typical Southern Ontario Hardwoods _ _ $\quad$ - 91

Map-Life Zones of Eastern North America - $\quad$ - 97

Fern Colony, Osmunda Claytoniana _ _ $\quad$ - 141

Sphagnum Bog Vegetation, Wilcox Lake _ $\quad$ - 152

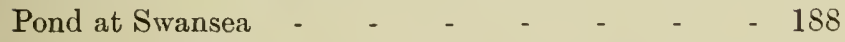

Detail Map of the County of York and portions of adjacent Counties of Peel, Halton, Simcoe and Ontario - $\quad$ - $\quad$ - $\quad$ - $\quad$ - $\quad$ - $\quad$ - Pocket

Detail Map of the Counties of Lincoln and Welland, with portions of Halton, Wentworth and Haldimand - - - - - - - Pocket

Road Map, Toronto and Environs - _ _ - Pocket 



\title{
The Natural History of the Toronto Region
}

\section{CHAPTER I.}

\section{TORONTO: AN HISTORICAL AND DESCRIPTIVE SKETCH}

\author{
By \\ DAVID REID KEYS, M.A., \\ University College, University of Toronto
}

WHEx that genial and rersatile geologist, the late N. S. Shaler, wrote the history of his native State, Kentucky, he drew attention to the peculiar position it held among the American commonwealths. Kentucky alone, he said, is the child of another commonwealth, Virginia, and owes the majority of her early inhabitants to the soldiers disbanded at the close of the American revolutionary war. In the same manner, and almost to the same extent, the first settlers in Upper Canada, as it was then called, were the loyalist soldiers of the British army, and the other $\mathrm{U}$. E. Loyalists whose devotion to a lost cause led them to prefer expatriation to life under a new flag. To make the parallel still more exact, not a few of these sturdy loyalists came from Virginia and founded some of the first families of our prorince. 


\section{NATURAL HISTORY, TORONTO REGION}

The early history of the Jesuit settlements in Ontario, which might find a Kentuckian parallel in tales of "the dark and bloody ground," lie outside our subject, being dealt with by Professor A. F. Chamberlain, the best authority on the Indians of this region, in a special paper. The geological basis for the history of Toronto has also been made the subject of an article by Professor Coleman. In that article it appears that from far distant ages the neighbourhood of Toronto was distinguished as the embouchure of a great rirer from the Northland, discharging the waters of the vast inland seas of that early era into a lake which was much larger than the present Ontario. Had this river remained to our time Toronto might have been already a second Chicago. But the oldest. records sar that the site was a well-known Indian trading-post and centre of exchange, one of the most popular etymologies for the name being " a place of meeting:" and a place of meetings Toronto has certainly been. Two great trails crossed here, one from the north, the other from the west: and danger and honour hare met more than once at the crossing."

The first reference to Torouto quoted by Dr. Scadding in his delightful rolume of "Collections and Recollections," is found in a Memoir on the state of affairs in Canada, transmitted to France in 1656 by the Gorernor of the dar, the Marquis de Denonrille.

Referring to preparations for meeting a hostile ad-

* "Send danger from the east unto the west,

So honour cross it from the north to south,

And let them grapple."-Shakespeare, I Hen. IV, I: iii. 


\section{TORONTO: AN HISTORICAL SKETCH}

rance of the English, he writes to the minister de Seignelay: " M. de la Durantaye is collecting people to entrench himself at Michilimaquina and to occupy the other pass which the English may take by Toronto, the other entrance to Lake Huron. In this way our Englishmen will have somebody to speak to. All this cannot be accomplished without considerable expense, but still we must maintain our honour and our prosperity." By the middle of the next century (A.D. 1749) a stockade was erected and a trading post established at Toronto. This measure was intended to cut off the Indian trade from the English post which had been established at Oswego, or Choueguen, as it was then called. The new French fort was named Fort Rouille, after the Colonial minister, and was visited soon after its foundation by the famous "apostle of the Iroquois," the Abbé Picquet. He found the bread and wine good, an opinion which subsequent French visitors have not always shared, but doubted the wisdom of establishing a rival to the trading posts at Forts Frontenac and Niagara. The 1756 destruction of Oswego at the beginning of the Seren Years' War seems to hare led to the abandoning of the new trading post, although the name continues to appear occasionally in dispatches. "The Journals of Major Robert Rogers," which were published in London, A.D. 1765, gire an account of the visit he paid to Toronto in September, 1760, in the course of an expedition to take possession of Detroit. After describing the joyful reception and the impor- 


\section{NATURAL HISTORY, TORONTO REGION}

tant information which the Indians gave him, he continues: "I think Toronto a most convenient place for a factory, and that from thence we may rery easily settle the north side of Lake Erie."

It is interesting to note an observation of Sir Wm. Johnson made in 1767: "I have heard traders of long experience and good circumstances aftirm that for the exclusice trade of that place (Toronto), for one season, they would willingly pay $£ 1,000$ - so certain were they of a quiet market-from the cheapness at which they could afford their goods there." In its early acceptation the name Toronto was applied to all the district lring north as far as Lake Simcoe, and it was also used for that lake on eighteenth century maps.

During the rerolutionary war it was happy in haring no histors, but at the conclusion of the conflict the influx of U. E. Loyalists began. MajorGeneral Simcoe, who had fought under Lord Cornwallis, was appointed Lieutenant-Governor of the new prorince of Lipper Canada, created under the constitutional act of 1791 .

Under his administration Toronto was first laid out on its present site by Surveyor-General Bouchette. At this date also, Yonge Street was planned as a road to the Georgian Bay and named after Sir George Yonge, then Secretary of War. The town itself was christened York in honour of the soldier-son of George III. 


\section{TORONTO: AN HISTORICAL SKETCH}

The plan of the future capital was drawn in that rectangular form which the military engineers of the Romans impressed on the conquered prorinces of Europe, and of which the city of Chester is an interesting survival. However suitable for the camp of a Roman legion, or for the compact walled cities which grew out of such camps, this rectangular mode of laying out streets has proved far from practical for the widely extended cities on the American continent, where land is plenty and wars are rare. Professor Shaler had a theory that the Roman empire fell because of the economic waste due to the rast cost of the Roman roads. It is highly probable that the yearly loss due to the Roman system of laying out cities would build any road in the Roman empire. Few cities show this fault in so marked a degree as Toronto. In its growth from the tiny rectangle enclosed by George, Duke, Berkeley and Palace (now Front) Streets, about an eighth of a square mile in extent, to its present area of over thirty-two square miles, there has been hardly any variation in the rigid angularity of its outlines. Neither hill nor dale, creek nor river, bluff nor rarine has been allowed to deflect the monotonous straight lines of its streets. This is the more surprising since the few exceptions which help to prove the rule are so striking. The fine rista effects of the City Hall at the head of Bay Street, Osgoode Hall at the head of York, and the Parliament Buildings facing the Queen's Arenue were as barren of influence on the 


\section{NATLRAL HISTORY, TORONTO REGION}

minds of our town-planners as the meandering ways of Rosedale.

Te cannot blame the first builders of the city for neglecting the aesthetic. Ample provision was made for the parks and squares of the future city. The original Parliament Buildings were constructed on the shore to the south-east of the little capital, and the road along the shore to the Old Fort at the western entrance to the harbour, while as straight as Appius or Agrippa could have desired, was bordered by grores of oak, and in the early prints suggests a scene of sylran beauty. By some the name Toronto is said to mean "oaks by the water." If so it ceased to be appropriate with the coming of the railways in the "fifties."

Long before that date York had receired its baptism of fire and blood. The war of 1812 was due in great part to the bad feeling that had remained in the South and West, particularly Kentucky, since the Indian wars. This feeling was intensified by the massacre of Frenchtown, or Raisin River, in January, 1813, when several hundred Kentuckian prisoners were killed by the Indian allies of General Proctor. In the following April a large force, under General Pike, of New Jersey, attacked York, which then contained about fire hundred inhabitants and a somewhat larger garrison. In the defence of the fort a terrible accident occurred which has been described as follows by an eyewitness: "A gun was aimed at one of the vessels, and the officers, desirous 


\section{TORONTO: AN HISTORICAL SKETCH}

of seeing if the ball would take effect, ascended the bastion. In the meantime the artilleryman, waiting the word of command to fire, held the match behind him, as is usual in such circumstances; and the travelling magazine, a large wooden chest, containing cartridges for the great guns, being open just at his back, he unfortunately put his match into it, and the consequence was dreadful indeed. Every man in the battery was blown into the air. The officers were thrown from the bastion by the shock, but escaped with a few bruises; the cannon were dismounted, and the battery was rendered completely useless. I was standing at the gate of the garrison when the poor soldiers who escaped the explosion with a little life remaining were brought into the hospital, and a more afflicting sight could scarcely be witnessed."

The American general, Pike, was killed by the explosion, as well as a large number of his men, and on the capture of the town the Parliament Buildings were burned. It was partly in reprisal for this act that the British forces destroyed the Government Buildings at Washington some months later, when General Ross captured that city. That New England was opposed to the war the Hartford Convention clearly showed. While thus tending to separate the Union it did much to consolidate the Provinces, for the French were quite as vigorous in their defence. as the Loyalists of the Upper Province. There can be no doubt that the success with which the Canadians repelled the invader was mainly owing to the 


\section{NATURAL HISTORY, TORONTO REGION}

military character of the early settlers, to which reference has already been made.

Among the first inhabitants of York were many half-pay officers of both the army and navy, including several surgeons. The social predominance which naturally fell to their share led to a political leadership that culminated in the "family compact." By one of the little ironies of history the seat of this cabal was the "Grange," afterwards the home of Professor Goldwin Smith. It was built by Mr. D'Arcy Boulton, in the outskirts of the town. Dr. Smith was fond of telling how Justice Boulton's two carriage horses, Bonaparte and Jefferson, had once attacked a bear in their pasture before the "Grange." The house stands in beautiful grounds at the head of John Street and was bequeathed with Professor Smith's collection of historical portraits to the city.

The military governors-Sir Peregrine Maitland, who had eloped with the daughter of the Duke of Richmond after the famous Waterloo ball, and Sir John Colborne, who founded Upper Canada College in 1829-were both supporters of the oligarchy. But it was Sir Francis Head, " the tried reformer," under whose rule the discontent of the reformers led by 1837 William Lyon Mackenzie came to an outbreak. Toronto, which had resumed its old name on its 1834 incorporation as a city three years before, again approved its loyalty, and the rising was put down. 1839 But the defeat of the reformers was to result in the triumph of reform. The Earl of Durham, who suc- 


\section{TORONTO: AN HISTORICAL SKETCH}

ceeded Head, sent in his famous report, which is said to have been written by Charles Buller, his secretary, the friend of Tennyson and the pupil of Carlyle. To this we owe the establishment of responsible 1846 government and the abolition of abuses. As a result Toronto, now one of the capitals of a united Canada, made rapid advances, and though its prosperity was temporarily checked by the adoption of free trade in England, it received an added impetus by Lord Elgin's Reciprocity Treaty with the United States.

During these years the growth of both city and province had been slow but steady. The early settlers came mostly from the south, including the "Pennsylvania Dutch," of whom a number took up land to the north and east of Toronto, in the neighbourhood of Markham. After the war of 1812-13 this influx ceased, and the new settlers came from the British Isles, especially Scotland and the north of Ireland. To this day Toronto is the greatest Orange centre except Belfast. After the famine the Irish came in great numbers and suffered terribly from the ravages of the fever and the cholera epidemics which raged in 1847 and 1854. The Roman Catholic Bishop Power, after whom Power Street is named, sacrificed his life in the former year while ministering to these unfortunates.

The first Toronto "boom" broke after the Crimean War in 1857. The opening of the Northern, Grand Trunk and Great Western Railways had facilitated transportation, stimulated commerce and en- 
couraged immigration. The war had raised the value of all agricultural products, and the price of land on Yonge Street advanced to figures that would seem small now but were thought extravagant by the prudent of that day. The gold fever in Australia and British Columbia had fired the imagination and helped to bring about this era of speculation. It was not long before the Civil War in the United States once more gave an impulse to trade in Canada, soon lessened, however, by the abrogation of the Reciprocity Treaty. During the war a number of Southerners took up their abode here, making their rendezvous in the Caer Howell Hotel on the Queen's Avenue. The excellent schools and colleges had already begun to attract students from both North and South.

The provincial school system had been modelled after those of Ireland and of Prussia by the Superintendent of Education, Dr. Ryerson. Upper Canada College, the Eton of Canada, had been brought to a high state of efficiency under Principal George R. R. Cockburn. The University, founded as King's College in 1842, had been freed from the control of the Church of England in 1850, and was in other ways keeping pace with the spirit of the age. Bishop Strachan, who had been President of the University, although now over seventy, had collected the endowment of a new Anglican institution, Trinity College. The Presbyterians had also their theological school, Knox College, which after many moves and more than a half-century in affiliation with the Uni- 


\section{TORONTO: AN HISTORICAL SKETCH}

versity of Toronto, is now (1913) erecting what will probably be its permanent home on the west side of the University lawn. St. Michael's College was founded by the Basilian Fathers from Annenay, France, in 1852, and affliated with the University of Toronto in 1881. It occupies a pleasant site to the east of the Queen's Park, on St. Joseph Street. Another Anglican school of divinity, now called Wycliffe College, was established in 1377 and is located on Hoskin Avenue, north-west of University College.

The rise of the historical method and the growth of modern science rendered an increase in libraries and laboratories an imperative necessity if higher education in Ontario was to keep abreast of the age. Confederation was the result, and the University now includes four Arts colleges within its system, in addition to a number of affliated institutions less closely connected with it. University College represents the original foundation and is still maintained by the state, $\nabla$ ictoria (Methodist) federated and removed from Cobourg to Toronto in 1892, Trinity followed in 1904, and St. Michael's in 1910. This wise policy, aided by the enlightened support of the government, the upward trend of the school system, and the desire for learning characteristic of the Canadians has made the University one of the largest on the continent and the best attended in the British Empire.* Its various faculties of Arts, Law, Medicine

* Exclusive of India. 


\section{NATURAL HISTORY, TORONTO REGION}

and Applied Science had last Jear 4,136 students and 432 members on its teaching staff.

This wonderful advance in the field of higher education, appealing as it will to the scientific reader, may be taken as typical of the material growth of the city. That growth has been largely the result of the policy of protection brought in under Sir John A. Macdonald in 1878, which gave an immense impetus to manufacturing in Toronto. In 1881 the population was 82,000 , and in 1891 it had grown to 181,000. Germany itself could scarcely show more rapid progress. Would that Toronto had followed the German system of extension and town planning! With the wastefulness characteristic of the American continent, an area almost as large as that of Paris was paved and drained. The natural result followed, and during the next ten years the city only grew to 208,000 , the boom haring burst early in the decade.

With the turn of the century came a change. Sir Wilfrid Laurier's epigram that the twentieth century was to be Canada's seems to have won farour "there where the will and the power are one." A series of events brought Canada into the public eye. The British preference did as much for the increase of British immigration as it did for British trade. At the same time the tide of American immigrants flowed across from the Western States in constantly increasing volume. From the European continent, too, a flood of foreigners entered the Dominion, which has thus become the scene of a new "Wandering of 
the Nations," of a more peaceful character than that which helped to destroy the Roman empire. This morement has come not to destroy but to fulfil the destiny of Canada as the melting-pot of nations and the solvent of Anglo-Saxondom. At the May Day 1913 meeting of United Workers of Toronto speeches were giren in Polish, Bulgarian, Finnish, Yiddish, and Italian, as well as English, adrocating education and favouring peace. It is reassuring to know that the dominating proportion of the population of the Dominion, 54 per cent. in 1911, is still of British origin. The English gained 562,000, or 44.5 per cent., from 1901 to 1911, the French 406,000, or 24.5 per cent., the Germans 82,000 , or 26 per cent. The Irish population increased 62,000 to $1,050,000$, and the Scottish 198,000 to 998,000. The only other Europeans making six-figure records in Canada are Austro-Hungarians, 129,000, and Scandinavians, 107,000. Both the Indian and Negro records are decreasing. The total population was $5,371,315$ in 1901 , and $7,206,634$ in 1911, a gain of $1,835,328$, or 34 per cent.

In this advance Toronto more than held its own. According to the census of 1911 the population was 376,240 , and the official estimate (June 5th, 1913) is 488,000 . Territorially the city extends about ten miles from east to west along the lake front, and by the recent addition of North Toronto its northern and southern limits lie equally far apart. 


\section{NATURAL HISTORY, TORONTO REGION}

During the first decade of the new century Toronto's progress has been phenomenal. It has also been all-embracing. Millionaire manufacturers, successful merchants, retired farmers, half-pay officers, English gentlemen, Italian navries, Polish push-cart rendors, Greek bootblacks, and such a polyglot horde from the Balkans that three thousand are said to have left for the seat of war last year-all these and many more have come to spend or gain a fortune in Toronto. After having been for a generation a miniature Belfast, with a tincture of Edinburgh and a tinge of Glasgow, Toronto bids fair to become a Canadian Chicago with an unassimilated foreign element that is both a burden and an incentive to the charitable organizations of the city.

Nowhere is this change so apparent as in the district known for half a century as the "ward," and bounded by Queen, Yonge, College, and the Avenue. In the early days of Queen Victoria's reign the late Chief Justice Macaulay used to walk across the fields from his residence near the present site of the Bishop Strachan School to the Court in Osgoode Hall. Fifty years ago it was quite built up and peopled almost entirely by North of Ireland immigrants, mostly members of the Orange order, and well represented in the City Council by the late Mayor Warring Kennedy and on the School Board by Mr. Frank Somers. At the present time the "ward" still retains at its diagonally opposite angles, N.E. and S.W., the relics of the munificence of the earliest landorners in the 
open spaces of Osgoode Hall, presented as a gift to the Law Society by Sir John Robinson, and Wykham Hall, formerly the residence of Sir James Macaulay, and now the seat of the Bishop Strachan School. At the opposite corners of the other diagonal, S.E. and N.W., the energy and generosity of the North of Ireland still find fitting representatives. The one contains the immense establishment-stores, factories, stables and garages-of the T. Eaton Company, unsurpassed as an example of rapid commercial success. The firm in its building operations seems to be executing an echelon morement by squares to reach the opposite north-western angle of the "ward." Here the splendidly-equipped surgical wing of the new General Hospital bears witness to the generosity of Mr. J. C. Eaton, the present head of the Company.

Within the central space between these points lies closely congested the greater part of Toronto's foreigu population. Six synagogues and half a dozen foreign missions indicate the cosmopolitan character which the "ward" has now assumed and the efforts which are being made to assimilate and Canadianize its new denizens. To the lover of the picturesque and the cosmopolitan a walk through this region is an unfailing source of delight. The eye of the pessimist sees "slums" writ large over the district. The optimist rejoices in the sight of this teeming life, so eager to reproduce itself, so hopeful of the outlook in this land of magnificent opportunities, so confident of gaining, not only a comfortable livelihood, but an 


\section{NATURAL HISTORY, TORONTO REGION}

assured competence by the growth of the nation's: wealth. One hears of push-cart men becoming semimillionaires within a ferw years, and the stimulus of such tales is not lost in the telling. In Toronto, as in New York (Borough of Manhattan), the downtown landowners are mostly corporations or Jews.

But, typical as it is in many respects, the "ward" is not all of Toronto. The backbone of the city's population, its pith and marrow, are still Canadian. And as Canadians their interests are chiefly in the home life. A drive in a tally-ho, a view from the tower of the University or of the City Hall will convince the visitor of this fact. Ferw, if any, of the cities of America, certainly none in Europe, can show so many miles of comfortable and even commodious dwelling-houses in proportion to the population. But. here, too, conditions are changing. Seven years ago there were only three apartment houses in the city. Now they number 300 . With the great increase in land values, the decrease in the supply of domestics, and the lowness of the Ontario birthrate, such substitutes for the true home are sure to be multiplied. Hitherto they seem to have had no effect in diminishing the rapidity of the city's territorial growth.

That growth has been guided to some extent by the geological conditions. The successive hill-plateaus which mark the earlier shore-lines of Lake Ontario formed boundaries to the north, and so the city till quite recently expanded east and west along the lake front till it extended from the Humber Bay 


\section{TORONTO: AN HISTORICAL SKETCH}

and River on the west to Scarborough Beach on the east, taking in the Harbour and Ashbridge's Bay, and thus having nearly twenty miles of coast-line within the city limits, owing to the semicircular form of the Island and the double coast at Simcoe Park. But when the electric trolley climbed the bluff known to geologists as the "Iroquois shore," less than three miles north of the bay, the development of this lofty and healthy district began, and within three years it has become the most fashionable part of the city. Land which cost eighteen dollars a foot ten years ago is now held at $\$ 175$, and hundreds of acres have changed hands at even greater advances than this. The average value of the houses on the Avenue Road hill ranges from $\$ 12,000$ to $\$ 15,000$. This is without taking into account the mansions which line the hill and dominate the city with an unsurpassed distinction of site and variety of type. The old English hall, the Norman-French chateau, the Italianate mansion, and the mediaeval castle are all to be found, and so spacious are the grounds surrounding them that there is no sense of incongruity produced by the different styles. The castle of Sir Henry Pellatt, at the head of Walmer Road, with its adjacent stables and gardens, will form when completed one of the most magnificent residences on the continent.

Proud as Torontonians may well be to see such splendid dwellings rising in the city, and to know that they represent in concrete form the result of the business energy, acumen and executive skill of some of 
their fellow-citizens, there is even greater cause for pride in the general diffusion of a comfortable competence that is evident in every quarter and along every car line in the city.

Nowhere is it more in evidence than on Toronto's unique summer resort, "the Island." Years ago Charles Dudley Warner called it our Lido, but both the Lido and the Island have been altered much since then. The former shows by its vast caravanserais and monotonous rows of wooden bathing-houses that it has become a summer resort for thousands of European and American tourists; the latter has become the holiday home of the multitude of citizens whose business or whose tastes keep them in town during the summer. Families of all degrees of wealth and social standing pass their vacations here, and in consequence there is much greater diversity of character in the residences than on the Lido. There is no tramway, however, as at Venice, but the geologist is sure to be a walker and will find much to interest him in a visit to this silting spit of land which by creating its future harbour determined the site of Toronto. Hanlan's Point, on the west, is the popular resort, with its baseball grounds, its outdoor entertainments, its aquatic sports and its air of a perpetual kermesse. A few minutes' walk to the south and we come to the older cottages dating from the eighties, when the "mania for summer-outings" first struck Toronto. Goldoni called it a mania; to us of the twentieth century it is the highest wisdom. 


\section{TORONTO: AN HISTORICAL SKETCH}

It was a professor of mathematics who led the way, and certainly there is no better place to study hydrodynamics in its relation to geography. At the southern extremity of this row of cottages stands the Lakeside Summer Home for Sick Children, the gift of Mr. John Ross Robertson, who also built the Hospital for Sick Children on College Street, the most appealing of Toronto's many charitable institutions. Few sights are so touching as the annual moving in May of the little patients and their nurses from the city to the Lakeside Home. Turning to the left, we pass the lighthouse which for years has guarded this point and is the one building that knew the Island as a peninsula. For it was not till 1853 that the Eastern Gap, now the ordinary entrance for vessels from the south and east, was broken through in a violent storm. Beyond the lighthouse are the pumping station and filtering basin of the water-works, and in the offing we see the bell-buoy which marks the end of the intake pipe and whose mournful note suggests recollections of water famines and disinfected microbes, now happily matters of ancient history. A pretty little church hard by is used by different denominations in turn, recalling the fact that Church Union has made more progress in Canada than elsewhere and that there is a good prospect of the Congregational, Methodist and Presbyterian Churches uniting within the coming decade. On May 22, 1913, an Anglican Church Unity Society was organized in Toronto. As we go east little road- 


\section{NATURAL HISTORY, TORONTO REGION}

ways run north from the main plank walk. towards the inner lagoon, giving charming glimpses of a truly Venetian combination of canals and streets. One of these cross roads leads to Centre Island Park, famed for family picnics and amateur baseball matches. East of this, on the northern or harbour shore of the Island, are the grounds and clubhouse of the Royal Canadian Yacht Club, the scene of many delightful social functions.

Toronto first became celebrated as the home of the world's champion rower, E. J. Hanlan, and its supremacy in aquatic sports has been well maintained. O'Connor and Lou Scholes were also world champions, the latter winning the Diamond Sculls at Henley in 1904. His brother John had previously won the amateur light-weight boxing championship of England and America, a combination of honours not likely to be repeated in one family. Goulding, the champion walker of the world, and G. S. Lyon, the champion amateur golfer of America at the St. Louis Exhibition, are also Torontonians. Athletics are extremely popular. Thousands take part in both summer and winter sports, for which the climate usually gives ample opportunity. Although lacrosse is the national game, hockey is the favourite in winter and baseball in summer. The cool and beautiful location of the ball grounds at Hanlan's Point helps to swell the attendance, which sometimes reaches twenty thousand. Toronto has seldom experienced more dramatic moments than when the Upper 


\section{TORONTO: AN HISTORICAL SKETCH}

Canada College hockey team won the junior cham- 1902 pionship of Ontario in the last minute of the second extra ten, or when the Toronto team won the baseball pennant from Newark in the tenth inning of the last match of the season.

Clean, manly sport in Toronto owes much to the Young Men's Christian Association. This body showed its hold on the citizens by collecting orer $\$ 600,000$ in a two weeks' whirlwind campaign in 1910. The new main building is on College Street, near Yonge, and deserves the inspection of all who are interested in the training of young men. There are several branches throughout the city and a separate organization for young women, as well as a number of settlements, one of which is under the special charge of the University students.

The above forms of Christian activity may be called the resultant moraines of the churches for which Toronto is famous. It is the seat of a Roman Catholic archbishop and of an Anglican bishop, and the Canadian centre of the other chief Protestant denominations. One picturesque local society, which would have interested such travellers as Hepworth Dixon or Bayard Taylor, and which we read of in Dr. Scadding's " Toronto of Old," seems not to have survived its founder, David Wilson, of Sharon, after whom the members were called "Davidites," "Wilsonites," or "Sharonites." Their Temple, built in 1825, twenty years before the first Mrormon one at Nauvoo, Ill., was of quaint construction and curious 


\section{NATURAL HISTORY, TORONTO REGION}

rites, and "resembled a high-piled house of cards." Sharon was some distance north of the city, but the leader used to drive into town periodically with his seraphic band, and treat the citizens to a procession of the "Children of Peace," followed by a sermon on the depravity of public affairs. By virtue of their name let them live in David's record "one day more," recalling, like the tufa hills in the Hackensack Valles, an outburst of long-forgotten ferrour.

The archiepiscopal church of St. Michael has been compared to York Minster, and has stained glass windows that came from Munich, although they do not equal those in the Frauenkirche. Among the Anglican places of worship the most notable are the mother church of St. James, whose spire (316 feet) was for years the highest on the continent, the cathedral of St. Albans in process of erection, and Archdeacon Cody's beautiful new Gothic church of St. Paul's, the third enlargement (a definitive edition, let us hope) of that "house of prajer" since 1900 . The Metropolitan Methodist Church is beautifully placed in Magill Square on Queen Street East, and has one of the largest organs in America. This imposing pile has the distinction of having set the fashion for large and handsome churches in Toronto, and is itself due to the good taste of the late Rer. William Morley Punshon, afterwards President of the Wesleyan body in England. Many other beautiful and 


\section{TORONTO: AN HISTORICAL SKETCH}

spacious church edifices adorn the city, which is as renowned for its congregations and preachers as for its churches.

To the archaeologist and the lover of local history the most interesting fane in Toronto is the "Holy Trinity," overshadowed, like its namesake in New York, by the stupendous erections of modern commercialism. For here, in the parish rectory on the little square, lived and wrought and wrote the late Dr. Henry Scadding, author of "Toronto of Old," and one of the most reverend figures in the early history of the city. In this place, too, worshipped the Earl of Elgin, coming from his governmental residence in Elmsley Villa, afterwards the seat of Knox College, and now the site of the Central Presbyterian Church. Another name connected with Holy Trinity is that of Bishop Selwyn, of New Zealand, the famous missionary, whose preaching in the church, as well as that of Scoresby, the Arctic navigator, Dr. Scadding duly records.* Its own perpetuation as a down-town mission is ensured by the bequest of its founders, two English sisters. Little 1846 did these ladies, or the rector who chronicled their pious gift, imagine that before another generation had passed the sylvan parish church which they remembered would be surrounded, like a boulder at

* Half a century before, General Simcoe, the founder of Toronto, had set up the tent of Captain Cook, the circumnavigator and explorer of Polynesia, near the foot of Jobn Street as his summer residence. 


\section{NATURAL HISTORY, TORONTO REGION}

the bottom of a pothole, by the adrancing icecap of a new commercial age.*

The Peabody of "Little York" was Jesse Ketchum, a Buffalo tanner whose memory should serve as a bond between these sister cities so nearly akin in all but nationality. He owned the land between Yonge, Adelaide (then Newgate), Bay and Queen (then Lot) Streets, and supplied sites for eight or ten churches and other religious edifices within this district. All are now gone-the last to be remored being Knox Church from Queen Street West to its present beautiful building on Spadina Arenue. The failure to secure the former site and the rest of the block as a Court Square was one of the most extraordinary oversights in town-planning that even Toronto can show. Opposite to St. Andrew's Presbyterian Church on King Street West another opportunity was lost. Here three squares were public property and were largely free from buildings. A site for a Court of Honour like that which Cleveland is spending millions to acquire lay ready to hand and might have been secured for a few hundred thousands. But Jesse Ketchum died in 1867 and his example has been followed by few of Toronto's wealthy citizens. A Guild of Civic Art exists, and, with the aid of one public-spirited alderman, has made a start in restoring the old lake-side

* A boulder of the drift, lifting itself up through the natural turf, served as a desk for the recording clerk of the first Parliament of Upper Canada.-Scadding, " Toronto of Old," p. 29. 


\section{TORONTO: AN HISTORICAL SKETCH}

drive and promenade which was planned by Simcoe and which might be made as beautiful as the English garden at Geneva. When the plans of the Harbour Commission have been carried out Toronto will have achieved its destiny and secured the most beautiful and most valuable lakefront in America. And as the Duke of Brunswick gave a model theatre to the Swiss city of his adoption, so a native Torontonian has built the Alexandra Theatre in addition to starting the subscription for the new hospital. The Carnegie Library on St. George and College Streets is as perfect a model in its way as St. Andrew in partibus himself. The reading-room is unexcelled. The collection of paintings and sketches and photographs to illustrate the early history of Toronto is in the eastern gallery of the building, and is a permanent monument to the historic fair, the civic patriotism and publicspirited munificence of Mr. John Ross Robertson. It is also the best appendix to the present article, every page of which is indebted to Robertson's "Landmarks of Toronto" (5 vols. Toronto, 18941908).

The Public Library is also the centre for the exhibitions of the Canadian Academy of Art, the Ontario Society of Artists, and the Art Club. Literature is united with art in the work of the Arts and Letters Club, the Round Table, and the Strolling Players, the last being rather social than scientific. Among purely social clubs the old-established downtown Toronto Club, on the corner of York and Wel- 


\section{NATURAL HISTORY, TORONTO REGION}

lington, and the new up-town York Club, on the corner of Bloor and St. George, are recognized as preeminent. The Albany, the Reform and the National have political leanings, although the last has lost much of its original significance. The Canadian and Empire are luncheon clubs, meeting weekly and listening to addresses from distinguished men, usually strangers, on topies of the hour. They indicate the growing intellectual interests of the community and the rising tide of Canadian sentiment. The most interesting historically of these luncheon clubs is the U. E. L. Association, the descendants of the United Empire Loyalists, who meet annually to celebrate the coming of their ancestors to Canada. Scientific subjects are dealt with by the Royal Astronomical Society, the Folklore Society, the Canadian Historical Society, and the Canadian Institute. The Institute has a home of its own on College Street, south of the University Chemistry building, with a good scientific reading-room and the best collection of Transactions of learned societies in Canada. It was founded as an engineering and scientific club in the year 1851, and its own publications illustrate in a very interesting manner the changes and developments in the methods of research during the last two generations.

But though often called the city of colleges, the interests of Toronto are essentially commercial and manufacturing. Even here, however, the printing and publishing trade holds a record. Toronto is said to be the fifth city on the continent in this line, being surpassed only by New York, Boston, Chicago and 


\section{TORONTO: AN HISTORICAL SKETCH}

Philadelphia. Leading English firms like the Macmillans print Toronto on their title pages in addition to London and New York. The largest manufactured output is in agricultural implements, liquors, hardware, musical instruments and ready-made clothing. The Hydro-Electric and Niagara Power companies supply the motive force for hundreds of factories, and new inventions are constantly adding to the number. There are more than 20,000 automobiles licensed in Ontario, and three-fifths of them are said to be in Toronto, giving an average of one to every sixth or seventh family. The retail trade is not less flourishing, and while a couple of great departmental stores would seem to the onlookers to get the bulk of this business, there is evidence in the tasteful and even luxurious appointments of many shops that large profits are being made elsewhere. The jewellers in particular are noted for their beautiful stores, and, as in the case of the churches, the taste of one man set the fashion for the rest. Diamonds are imported free, but other goods paid a duty of $\$ 775,000$ last year, which probably indicates a business of $\$ 10,000,000$, wholesale and retail.

From the macrocosm of the city we pass to the microcosm of the university. Here the meetings of the International Geological Congress will be held, so a brief account of the buildings will be of interest. The original King's College was on the site of the present Parliament Buildings in the Queen's Park. But in 1850 the institution was secularized, the name changed, and the system of administration altered to 


\section{NATURAL HISTORY, TORONTO REGION}

that of the University of London. The University thus became merely an examining body. The teaching of the Arts faculty was handed over to a new foundation known as "Unirersity. College," which became "the vital centre of the University." For this new college the beautiful Norman-Gothic building was constructed which is still its pride and its home. On St. Valentine's Day in 1890 a fire destroyed the eastern half of the stately pile, which contained the Library and the Convocation Hall. As in the case of the rare Arabian bird, this loss, apparently irreparable at the time, proved ultimately a gain, and the opening of a new era of expansion in the history of the University. Toronto for once sympathized, Quebec sent ten thousand dollars, and the Ontario Legislature passed an Act the next day providing for the restoration of the building in a manner more suitable to the enlarged classes which had begun to crowd its halls. The generosity of individual citizens supplied funds for a new library, to which came contributions in books from all parts of the world. Germany alone sent seven thousand volumes. The building is on the east side of the lawn. To the south-west rises the new Convocation Hall, due in part to the gifts of the alumni. The inner hall has admirable acoustic properties, and contains an organ, made by Casavant, of Quebec, in perfect keeping with its surroundings. Other University buildings around the lawn are the Medical, with its Palladian

* Chancellor Burwash, "The University of Toronto and its Colleges," p. 39. 


\section{TORONTO: AN HISTORICAL SKETCH}

towers, and the Biological, to the south of the Library; the School of Practical Science built of red brick, and the Thermo-dynamic building with its tall double chimney, to the south of the lawn; and the splendidly equipped Physics and Chemistry buildings, south of the Convocation Hall. On the corner of College Street is the department of Mineralogy and Geology in a building worthy of the important part which these sciences have borne, and are destined to bear in the development of Toronto, Ontario and the Dominion. Between the Mineralogy and the Thermo-dynamics buildings is the practical laboratory for mining and assaying. Farther east is the bureau of the Students' Y.M.C.A., soon to be removed to the magnificent Hart Hall now in course of erection to the north-east of University College at a cost of $\$ 1,100,000$, the gift of the Hart Massey family. This vast structure will house with unparalleled completeness the various non-academic activities of student life: physical, literary, histrionic, and religious. Still more opulent in its appointments is the department of Household Science, situated on the corner of Avenue Road and Bloor Street, in a building as beautiful in its external architecture as it is complete in its internal arrangements. Mrs. Massey-Treble, who has fitted this golden slipper on the Cinderella of the sciences, is likewise endowing the department in a manner consistent with its home and the new dignity she has conferred upon it. To the south of this building lies the complex of Victoria College, the Methodist member of Confederation. The newest of 


\section{NATURAL HISTORY, TORONTO REGION}

the buildings might have been remored bodily from Oxford. Its name, "Burwash Hall," commemorates the first chancellor under the new régime, to whose influence and statesmanship the federation movement owed much of its success. This hall is also the gift of the Hart Massey family. It is to be a residence for Victoria male students, the women being already provided for in Annesley Hall.

The University residences for men are north of Hoskin Avenue, and are also the gift, in part, of generous friends. North of this, on the corner of Bloor and Deronshire Place, is the stadium. On the opposite corner is the Meteorological Office, the first established in the British Empire outside the United Kingdom (1840). East of the stadium, on Bloor Street, is McMlaster Hall, the Baptist University of Ontario, which, after years of affliation with the state institution, got an independent charter about twenty years ago and has been doing steady and successful work in its own field ever since. It has secured twenty-fire acres north of the city and is preparing to more to the new site.

Trinity College, the Anglican representative which entered federation a few years ago, has already sold its grounds on Queen Street West and will presently build on its destined site south of Mcllaster Hall. Ten years ago these grounds, now almost completely corered with buildings, were used by the faculty as a golf-course, so rapid has been the development of the Lnirersitr. 


\section{TORONTO: AN HISTORICAL SKETCH}

But one building remains to be mentioned, the most interesting of them all. This is the University Museum, of which at present only the west wing is finished, on Bloor Street, east of MIclIaster Hall. It is to be completed ultimately by adding the front on Bloor Street and an eastern wing on Avenue Road, opposite the Department of Household Science and Annesley Hall. The museum owes much to private benefactions and is partly supported by the Province. It contains a great variety of collections and is admirably arranged to show the evolution in the progress of civilization. Egyptian and American antiquities are especially well represented. Lovers of the red man should not fail to see the Paul Peel collection of paintings in the west hall of the main building. To members of the Congress the main interest, of course, will be in the mineralogical and geological or paleontological specimens, of which detailed accounts will be found elsewhere in this handbook.

Members who take an interest in the flora of Toronto and its vicinity will find an article on that subject also. It may be added here for their benefit that the Department of Botany and the Faculty of Forestry have their home together on the east side of the Queen's park, on the south corner of Grosvenor Street. The park itself has very beautiful flowerbeds, but the most charming sights of this kind are to be seen in some of the private gardens of Rosedale, on the slopes in the neighbourhood of the new Government House. 


\section{NATURAL HISTORY, TORONTO REGION}

If the flowers of Toronto have grown more beautiful, the trees have degenerated sadly. Umbrageous groves of oak, beech and maple, diversified by occasional clumps of towering pine, seem to have characterized the scene-

"When wild in woods the noble savage ran."

Many noble elm-trees were scattered through the city. fifty years ago, and a few still survive. One splendid specimen is to be seen east of the Queen's Park, and just north of Wellesley Street. The pines do not seem to be able to endure civilization any better than the noble savage himself. The new tree surgery, or rather dentistry, is being applied to a number of the survivors of the forest, with what success remains to be seen. The favourite imported tree for shading purposes was the horse-chestnut, which, had it been planted regularly, as in Bushy Park, near Richmond, would have made the University Avenue one of the sights of America. But the effort was made to imitate nature, for the avenue was laid out in the days of the romantic movement, which in this case had a far from romantic result. The hatred of trees which was a heritage of the early settlers survived in Toronto till quite recently. In the University grounds the trees are labelled with their scientific names, as in Boston. May the fragrance of flowers and the beauty of trees combine with other pleasant memories in the minds of our visitors, as typical of Toronto, the "place of meetings"? 


\section{TORONTO: AN HISTORICAL SKETCH}

\section{SOME TORONTO STATISTICS.}

Area of city, 1913, 33.75 square miles. Total park area, $1912,1,605$ acres; $1913,1,743$ acres.

Population, 488,000 (estimate of city statistician). Death-rate, 12.8 per 1,000 (estimate of city statistician).

Number of buildings erected in 1913, 10,217; estimated value, $\$ 27,400,000$. mills.

Assessment of city, 1913, $\$ 436,000,000 ;$ tax-rate, $19 \frac{1}{2}$

Net debt of city, 1913, $\$ 33,000,000$. Revenue, 1912, $\$ 8,500,000$.

Miles of streets, 1912,$413 ; 1913,509$. Miles of sidewalks, 1912,$561 ; 1913,610$. Miles of sewers, 1912, 336; 1913,360 . Miles of water mains, 1912, 434; 1913, 458. Miles of gas mains, 1912,$456 ; 1913,473$.

Miles of street railway, 1912,$107 ; 1913,114$. Total revenue from street railway since 1891 (to 1911), $\$ 6,339,000$. Revenue from street railway (exclusive of taxes), 1912, $\$ 890,000$. Passengers carried, 1911, 121,000,000; 1912, 135,786,000 .

Attendance at Exhibition, 1912, 962,000.

Hydro-Electric meters in use, 1913, 18,000, with 15,500 horse-power.

Clearing House returns, 1911, $\$ 1,852,000,000 ; 1912$, $\$ 2,170,000,000$.

Custom House returns, 1911: Imports, $\$ 100,000,000$; Duty, $\$ 17,800,000$. 1912: Imports, $\$ 120,000,000$; Duty, $\$ 20,261,000$.

Total number of police, 588 .

Total number of firemen, 336 . Total loss on fires, 1912, $\$ 1,113,000$.

Number of tavern licenses limited to 110 ; fee, $\$ 1,600$; shop licenses, 50 ; fee, $\$ 1,600$.

Number of volumes in city libraries, 180,000; in University and Law libraries, 250,000.

Number of automobiles in Ontario (Provincial fee, \$4), 21,500 .

Number of births, 1912, 11,100; marriages, 6,153; deaths, 6,313 . 
CHAPTER II.

\section{THE INDIANS WHO FORMERLY INHABITED OR VISITED THE SITE OF TORONTO.}

By

\section{ALEXANDER FRANCIS CHAMBERLAIN, M.A., Ph.D.,}

Professor of Anthropology, Clark University, Worcester, Mass., Sometime Fellow in Modern Languages, University College, Toronto.

THe region which is now occupied by the capital of the Province of Ontario was familiar to two of the great Indian peoples of northeastern North America. The city's name, Toronto, although its exact derivation has not yet been satisfactorily determined, comes from one of the dialects of the Iroquoian stock; and the natives who inhabited the western end of Lake Ontario, at the close of the eighteenth century, were the Algonkian Mississagas, or Mississangas, whose tribal appellation still survives in Mississauga Avenue, in what was formerly the village of Parkdale, now a part of the city itself. The name is likewise preserved in Old Fort Mississauga, at the mouth of the Niagara River; Mississauga River, in the District of Algoma; and Mississauga Strait, between Manitoulin and Cockburn 
Island, in Lake Huron. Appearing, with a certain kind of normality, as Messissaga, Mississaga, Mississauga, or Mississagua, this word is spelt in the old records in more than a score of different fashions, running all the way from Messagues to Michesaking and Missinasagues. The Mississagas are the same people termed in some of the early French documents Cheveux levés (or Cheveux relevés), Nation du Bois, etc. Among the names given them by the various tribes of the Iroquoian stock were the following: Assisagigrone, Awighsaghroone, Achsisaghek, Nuakahn (Tuscarora name), Tisagechroone, etc. The word Missisaga, more correctly Missisagi, is derived from Missisaking, which in the language of these people, whose dialect is practically Ojibwa (or Chippewa), or very close to it, signifies " at the place of many river-mouths" (missi, saking), an appellation belonging properly to the River Mississauga, in the District of Algoma, the home of these Indians, when first heard of, in the early years of the seventeenth century-they are then described as "living around the mouth of the River Mississague," where the French met them in 1634. After the destruction of the Huron settlements by the Iroquois, the Mississagas began, early in the next century, to migrate into that part of what is now the Province of Ontario, lying between Lakes Huron, Erie and Ontario, and, about 1720 , the French established a post for trading with them at the western end of Lake Ontario. Some fifteen years later, they are 


\section{NATURAL HISTORY, TORONTO REGION}

reported as having villages or settlements at Missisauga River, Manitoulin Island, Kenté, Toronto River, Matcitaen, and the west end of Lake Ontario, besides at Lake St. Clair (and Detroit). In 1746 the Mississagas were admitted as the "seventh tribe" into the Iroquois League, having sided with the latter people against the French-the MS. in the Toronto Public Library (date $c$. 1801) still classes the "Mississagui," or "tribu de l'aigle," as an Iroquois tribe (i.e., "tribu des sauvages hurons"). For a time, some of the Mississagas even lived within the borders of what is now the State of New York. Their eastward progress in Ontario was barred by the Ottawas and the French,-they had a conflict with the latter near Cataraqui in 1705; and Charlevoix (1720) describes a "fire-dance" executed by the Mississagas of that region some years later. They figure prominently in the New York Colonial Documents of the eighteenth century. The descendants of these Mississagas, who migrated from the region north of Lake Huron, are to be found in the Mississaga Indians, numbering between eight hundred and nine hundred, who live to-day at Rice Lake and Alnwick, Mud (Chemung) Lake, Scugog Island (Lake Scugog), and in the settlement of the New Credit (Brantford). Some dwelt formerly on Grape Island, etc., in the Bay of Quinté.

The Indians at the New Credit are the most progressive of all the Mississagas, and they are the ones who formerly lived on the River Credit (given 


\section{INDIANS WHO INHABITED TORONTO}

this name because here the Indians obtained goods "on credit" from the whites) not far from Toronto, whence they moved in 1847. They have been largely successful in the assimilation of the culture of the whites and now compete with them in several ways on an equal basis. The Mississagas are practically all Christians, having been converted before the middle of the nineteenth century through the efforts of the Wesleyan Methodist Church in Canada, aided by Rev. Peter Jones, a half-blood Mississaga, chief and historian of his people, who translated in 1835 The First Book of Moses called Genesis into "the idiom of the Mississaga form of the Chippewa," as Schoolcraft phrased it.

In language, customs, habits, religious practices, etc., the Mississagas did not differ seriously from the Ojibwa or Chippewa,-Peter Jones described himself, e.g., as belonging to "the Messissauga or Eagle tribe of the Ojebway Nation," this bird serving as the "totem" or ensign of his people. The Mississagas buried their dead in the ground and blackened their faces as a sign of mourning. They had the custom of keeping alive the memory of the dead by conferring his name on some one else or adopting some one of the same name,-a number of white men and women have been named for this purpose by them, from Dr. Ryerson, in 1826 by the Indians of the Credit, to the writer of these lines, in 1888 by those of Scugog. The Mississagas were a fishing and hunting people; the mouth of the River Credit was 


\section{NATURAL HISTORY, TORONTO REGION}

then a celebrated place for spearing salmon, and the Indians annually camped at that spot for the purpose. When indisposed, the Indians of the Credit, in the early days, are said to have resorted to what is now "The Island," fronting the city of Toronto, to take advantage of its health-giving atmosphere. The Credit Indians made sacrifices to the lake as well as. to the river, the forest, etc. When overtaken by storm on Lake Ontario, they were accustomed to appease the angry spirit of the waters by the sacrifice of a black dog, around whose neck they tied a stone and cast him into the lake. Caves in the hills around Burlington Bay and the head of Lake Ontario were thought to be the abodes of spirits, - one of these was called Manitoa wigwam, "the devil's house." A spirit, who used often to sing and beat his drum, was said to live in a deep hole in the water, at the foot of a hill near the Credit village, but, soon after the coming of the white man, the spirit raised a great flood, and went down the river into Lake Ontario. The east bank of the Credit, about a mile from its mouth, was reputed to be the dwelling-place of the "Mamagwasewug," or "fairies," who used to paddle a stone canoe, disappearing into the solid rock on the shore when closely pursued. These "fairies" were the good genii of the huntsman, and to them were made offerings of bits of cloth, tobacco, etc. They often used to steal fish out of the Indians' nets. "Fairies" were to be met with also all over Burlington Bay. 


\section{INDIANS WHO INHABITED TORONTO}

The Mississagas had many feasts and festivals, especially in the old heathen days: the dog-feast, the deer, salmon, sturgeon, wild goose and sacred bear-oil feasts, etc. Some of the legends of the Mississagas have been recorded by Dr. A. F. Chamberlain, who has likewise studied their language. An interesting story is told of a Mississaga woman of the Credit, who had been to the city of Toronto to sell baskets. She returned by train. It was her first experience of railway travel, and, on getting off, she threw herself flat on the ground, declaring that she was "waiting for her soul to come." Mrs. Moodie, in her "Roughing it in the Bush," has some interesting anecdotes about the Mississagas of the region about Peterborough, Ont. Archaeological specimens from all parts of the country inhabited by the Mississagas are to be found in the Provincial Archaeological Museum, some from the site of the city of Toronto itself.

Further information concerning the Mississaga Indians will be found in the following works:

1. Anon. (date 1801-1805). MS., pp. 52, 8 vo. French and Indian. In the Public Library of the City of Toronto. Contains some 500 Mississaga words, some 400 phrases and sentences, about a dozen proper names and half-a-dozen short songs. The dialect represented is that of the Mississagas between York and Lake Simcoe. This MS. is important as giving one of the earliest known extensive vocabu- 


\section{NATURAL HISTORY, TORONTO REGION}

laries in the languages of the western Algonkian peoples of Canada.

2. Chamberlain, A. F. Notes on the History, Customs and Beliefs of the Mississaugas. Journal of American Folk-Lore, 1888, Vol. I, pp. 150-160. See also other papers by same author in this Journal.

3. Chamberlain, A. F. The Language of the Mississaga Indians of Skugog. Philadelphia, 1892. Pp. 84. The Bibliography lists practically all the literature reiating to these Indians. The text contains historical notes, myths and songs, vocabulary, etymological discussions, etc.

4. Jones, Rev. P. History of the Ojebway Indians. London, 1861. Pp. vi, 278. 


\section{CHAPTER III.}

\section{GEOLOGY OF THE TORONTO REGION.}

By

A. P. COLEMAN, Ph.D., F.R.S.

\section{INTRODUCTION.}

Toronto, which lies on the north shore of Lake Ontario near its western end, is a convenient centre from which excursions may be made by land or water to various points of geological interest in the region of the Great Lakes. Railroads radiate east, west and north, and steamers ply to the east, west and south, giving easy access to lake ports, especially Niagara. Toronto itself and its suburbs include some of the most important Pleistocene sections in North America, and within a radius of one hundred miles the main geological formations from the Archaean to the Devonian may be studied. Though the region has undergone no faulting or folding since the Archaean it has experienced important elevations and depressions and has preserved the record of a very complex and extraordinary series of events in the latest geological periods, including the action of ice sheets, of great lakes of different ages and levels, and of important rivers and waterfalls. 
The region is not one of high relief, the most elevated points to the south not exceeding 850 feet and to the east or north within 100 miles probably not going beyond 1,200. The highest point in the peninsula between the Great Lakes rises to something over 1,700 feet near Dundalk, 76 miles northwest of Toronto. Lake Ontario is 246 feet above the sea, Lake Erie 572 feet and Lake Huron 581.

Although the variations in elevation are moderate there is great variety of surface features, including gently sloping lacustrine plains, rolling uplands, and an escarpment which crosses the region from south to north with a sudden rise of 300 or 400 feet. It has adjoining it some of the greatest lakes in the world, as well as many smaller bodies of water, and it is well watered with streams of every dimension up to Niagara River, some, like the Thames or Grand River, with gentle, meandering flow, and others with rapids or waterfalls having a sheer leap of 160 feet.

Except in the Archaean portion to the north the rocky structure is uniform and undisturbed, the beds of sedimentary rocks dipping very gently to the southwest without folds or faults or interruptions by eruptive rocks.

From middle Palaeozoic times to the present, so far as known, the region has been dry land except where lakes have covered it owing to Pleistocene shiftings of level or to the damming of valleys by ice masses. The most dramatic episodes in its history are the advances and retreats of the continental ice 
sheets during the Glacial Period. The palaeontologist will find a variety of Ordovician, Silurian and Devonian fossils in the bed rocks of the region, the Pleistocene geologist may study a complex and important series of later depasits, the physiographer will observe a more interesting set of surface phenomena than could have been expected in a district without mountains, and the dynamic geologist may study the effects of glacier ice, of rivers, waterfalls and waves, and also see the evidences of important changes of level within post-glacial ages.

Within one hundred miles of Toronto the following geological formations are displayed:

Recent ...... Shore cliffs and wave-built bars.

Pleistocene .. Glacial, Interglacial and Post-glacial beds.

Palaeozoic.. $\left\{\begin{array}{c}\text { Devonian-Onondaga and Hamilton } \\ \text { beds. } \\ \text { Silurian-Cataract, Medina, Clinton, } \\ \text { Niagara and Guelph } \\ \text { beds. } \\ \text { Ordovician-Trenton limestone, Utica } \\ \text { and Collingwood shale, } \\ \text { Lorraine shale and } \\ \text { Queenston shale. }\end{array}\right.$

Archaean ...Granites, gneisses, greenstones and greenschists.

The vast interval between the lower part of the Archaean and the Palaeozoic is unfilled, and the 


\section{NATURAL HISTORY, TORONTO REGION}

perhaps equally vast gap between the middle of the Palaeozoic and the end of the Pliocene is likewise without a record. It is probable that during both great intervals the region was a land surface undergoing denudation. What took place during these times can only be inferred from the general geological history of North America.

The different formations within easy reach of Toronto will be taken up briefly as given above, beginning with the oldest and advancing to the most recent.

\section{ARCHAEAN.}

Archaean rocks are exposed ninety miles to the north of Toronto, and may be reached by any of the four northward-running railways, the nearest point by rail being Washago. After passing the boundary of the Archaean the traveller is struck by the change of scenery, rounded hills of reddish gneiss rising irregularly above valleys generally occupied by a lake; for the region stretching two thousand miles to the north of the Palaeozoic border is typical "rocky lake" country, with thousands of rock-rimmed bodies of water, summer playgrounds for the city dweller and tourist. They include the Muskoka lakes and dozens of others less known, as well as the eastern shore of Georgian Bay.

At the nearest points to Toronto the Archaean consists mainly of Laurentian granite and gneiss, with masses and bands of greenstone or greenschist, 
all crystalline rocks of eruptive origin, the dark green diorite or gabbro or hornblende schist being earlier than the flesh-colored granite and gneiss. The schistose cleavage generally to be observed in these rocks has a steep dip in most cases, and when traced for a distance tends to sweep as wide curves. The mapping of a considerable area usually shows that the granite masses are oval in shape and pass outwards into gneiss, the quartz and feldspar and mica taking on a parallel arrangement; while the greenschists and other rocks are apt to be squeezed into synclinal bands between the oval gneissoid masses. This is the arrangement characteristic of the batholithic type of mountain structure, and the present surface of hummocky hills displays a cross section through the base of former batholithic domes; long ago carved down to mere stumps.

Near Parry Sound rocks of the Grenville series, mica schists and fine-grained gneisses with crystalline limestone or marble, have been caught in the mountain-building process and are found in long bands between the elongated domes of granite and gneiss. In all cases the metamorphosed sediments just mentioned, and the green eruptives which have been upheaved by the ascending granite of the domes, are the oldest rocks. They formed the cold and solid crust which was invaded by the molten granite.

The later members of the Archaean, such as the Huronian, have not been found in the region within 100 or 150 miles of Lake Ontario, and the next for- 
mation, the Ordovician, follows after an interval long enough to destroy the Laurentian mountains, which were carved down to low hills, the region having been reduced to a peneplain.

Though the Archaean rocks are not found in place within ninety miles of Toronto, specimens of all their varieties, including marble, may be collected from the drift boulders in the neighborhood of the city.

The old Archiean surface sinks gently beneath the next sheet of rock and advancing southwards may be found by drilling at greater and greater depths below the surface. At Thornhill, fourteen miles north of Toronto, it has been found in a well at 1,200 feet below the surface and 600 feet below the level of Lake Ontario. At Toronto granite and gneiss and sometimes crystalline limestone are found at depths of 1,100 to 1,300 feet below Lake Ontario, showing a slope of about forty feet to the mile in the old land surface. It is nearly 1,000 feet below sea level at Toronto, and 2,500 on the north shore of Lake Erie.

As the ancient surface must have been leveled to a peneplain by denuding forces which can only act above the level of the sea, it is evident that vast areas of the old continental mass were warped down to form sea bottom before the Palaeozoic history of the region began. 


\section{PALAEOZOIC.}

Ordotician.

The rocks of the Archaean are usually well exposed on the flanks of hills, while the valleys are more or less drift-covered; but the Palaeozoic rocks seldom rise as hills and their beds have only a slight dip, so that they are commonly buried under boulder clay or old lake deposits. Their outcrops are to be looked for mainly along lake shores or river valleys and there are hundreds of square miles of southern Ontario where no exposures of solid rock have been found.

The Ordovician (Lower Silurian or CambroSilurian) forms the bed rock in most of the Toronto region, occurring at many points on the shore of Lake Ontario and less often at a distance from it. The subdivisions usually recognized are as follows:

$$
\text { Ordovician }\left\{\begin{array}{l}
\text { Queenston. } \\
\text { Lorraine. } \\
\text { Utica. } \\
\text { Collingwood. } \\
\text { Trenton. } \\
\text { Black River. }
\end{array}\right.
$$

Feathering out toward the north upon the uneven surface of the Archaean peneplain south of Bala, Washago and other points between Georgian Bay and the Thousand Islands one finds solid beds of Black River limestone. They are well exposed in quarries 


\section{NATURAL HISTORY, TORONTO REGION}

at Longford, south of Washago, near the northern branch of the Grand Trunk Railway on Lake Couchiching, and also at Kingston, at the east end of Lake Ontario.

The limestone may rest immediately on the steeply tilted gneiss, or there may be a thin sheet of coarse sandstone or conglomerate at the bottom. There is no doubt that the Black River beds once extended farther north and are now being stripped from the older crystalline rocks, exposing once more the Pre-Cambrian continental surface.

The Black River limestone is used for building stone and for lime-burning. It is not highly fossiliferous, the commonest fossils being Columnaria halli, Calapoccia canadensis, Maclurea logani and Gonioceras anceps.

Immediately above the solid limestones mentioned above there is often a limestone formed in thinner sheets with partings of shale, the Trenton limestone. This occurs on the east side of Lake Simcoe, along Trent River, and at several points on the shore of Lake Ontario, such as Cobourg, Port Hope and Trenton. It is much thicker than the Black River and is richer in fossils. The beds are so gently tilted that they appear horizontal to the eye, but by comparing the same horizon at different points a dip toward the southwest of thirty or thirty-five feet to the mile has been found.

The following fossils are frequently found in the Trenton rocks : 
Prasopora selwyni.

Dalmanella testudinaria.

Rhynchotrema inequivalve.

Orthis tricenaria.

Rafinesquina alternata.

Hormotoma trentonensis.

Protowarthia cancellata.

Isotelus gigas.

Bumastus milleri.

Ceraurus pleurexanthemus.

Resting conformably on the grey shaly limestones there are 150 to 250 feet of black bituminous shales belonging to the Utica and Collingwood formations, easily attacked by the weather, so that they are generally buried under the drift; but low exposures of them may be found near Lake Ontario at Bowmanville, Oshawa and Whitby, and also near Collingwood, at the south end of Georgian Bay. The shale has a distinctly bituminous odor when broken, and fragments put on a fire burn for a time, though the mass that is left still retains its shape. Oil was distilled from the shale at Collingwood in early days, but the discovery of petroleum put an end to the industry. At several points the black and partly combustible shale has roused false hopes of the finding of coal.

The shale is often very fossiliferous, iron pyrites being a frequent fossilizing material. Graptolites and certain trilobites, such as Triarthrus beckii and Ogygites canadensis (formerly called Asaphus) are 


\section{NATURAL HISTORY, TORONTO REGION}

very common. The following list gives the commoner fossils :

Ogygites canadensis.

Triarthrus beckii.

"

spinosus.

Lingula cobourgensis.

Lingula progne.

Rafinesquina alternata.

Diplograptus bicornis.

The Lorraine (Hudson River) shale follows the last formation without a break and extends, as low outcrops, along the shore of Lake Ontario from Toronto to Port Credit. Its best exposures are in the Don Valley brickyard, east of Rosedale, Toronto, along the Humber River south of Lambton Mills, and at a brickyard on the shore of Lake Ontario just west of Port Credit.

The shale is grey and non-bituminous, and at intervals of a foot or two there is a layer of impure limestone, which must be selected out before the shale is ground for brick-making. The limy layers are very fossiliferous, and Professor Parks gives a list of more than sixty species found along the Don and Humber Rivers. The commonest forms are as folTows:

Diplograptus pristis.

Bythopora delicatula.

Dekayella ulrichi.

Rafinesquina alternata. 


$$
\text { - }
$$

-

- 


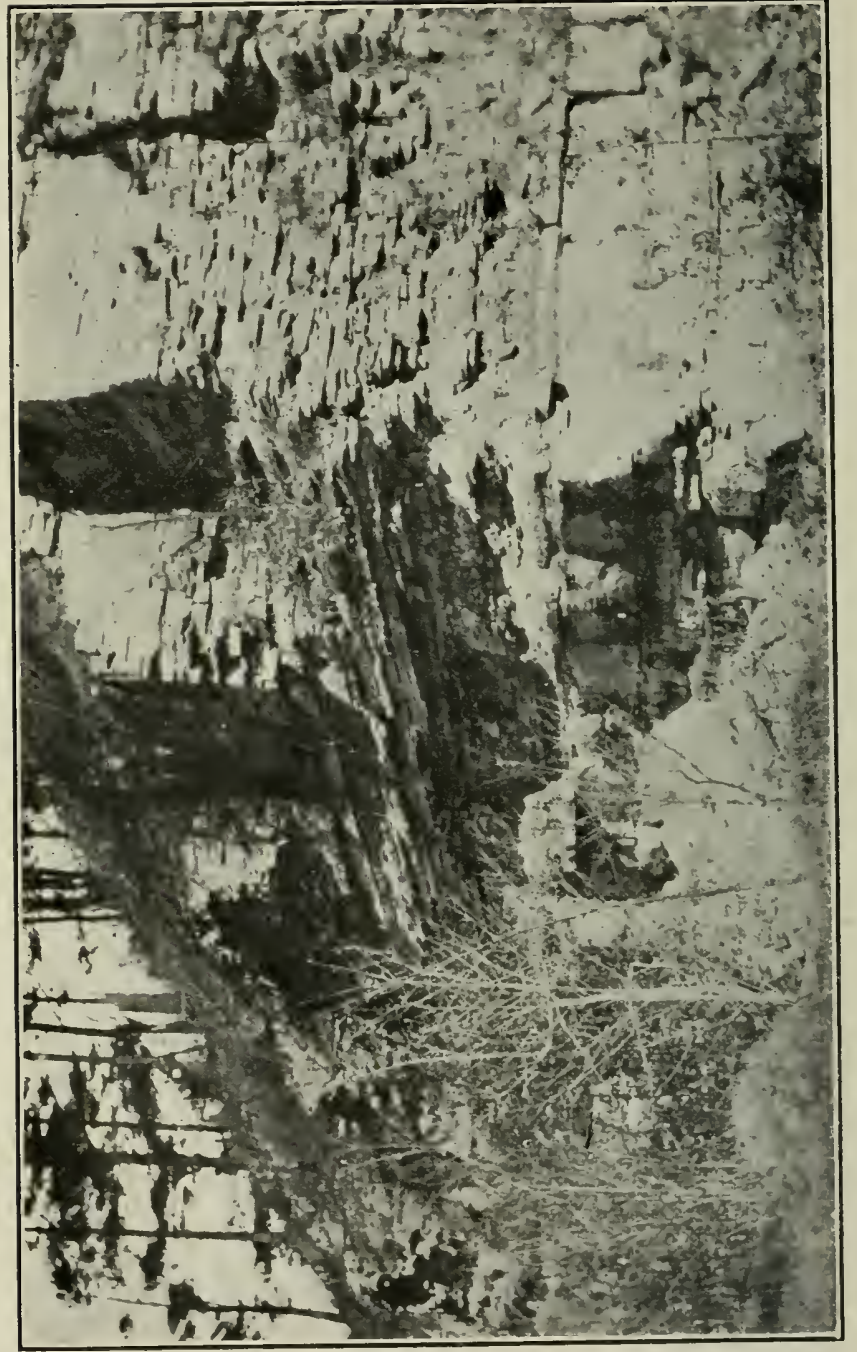

 
GEOLOGY OF THE TORONTO REGION

Plectambonites sericeus.

Catazyga erratica.

Cyrtolites ornatus.

Byssonychia radiata.

Whiteavesia pholadiformis.

Modiolopsis modiolaris.

" concentrica.

Orthoceras crebriseptum.

Isotelus maximus.

Calymene callicephala.

Richmond marine beds overlie the Lorraine toward the north and come as far south as Streetsville, but are not found along the shore of Lake Ontario. Going westward from Port Credit, Queenston red shale soon shows itself in river valleys and reddens the soil of the fields. It follows the Lorraine shale conformably and has the usual slight dip southwestwards. Continuing toward the west it forms the lowest part of the escarpment which runs from Queenston to Hamilton and then bends northwards to Georgian Bay. It is well seen at Queenston and in the lower part of the Niagara gorge, and may be followed along the foot of "the mountain," as the escarpment is called locally. At Waterdown and Milton it is manufactured into bricks.

The Queenston shale is very sparsely fossiliferous and in most places seems entirely barren, in this respect resembling many other red sedimentary rocks. The Richmond beds farther to the north contain many fossils of an Ordovician type. 


\section{NATURAL HISTORY, TORONTO REGION}

\section{SILURIAT.}

The Silurian (Upper Silurian) of southwestern Ontario includes a number of fairly distinct subdivisions which have been classed in various ways, the Niagara Limestone standing out most prominently at the crest of the escarpment before mentioned.

Professor Parks gives the following classification of the Silurian:

Salina .... Impure limestone and shale with gypsum and rock salt.

Guelph .... Dolomite.

Niagara .. $\begin{aligned} & \text { Lockport-Dolomitic limestone. } \\ & \text { Rochester-Shale. }\end{aligned}$

Clinton .... Limestone and shale.

Medina .... Sandstone and shale.

Cataract ... Sandstone, etc.

All of these subdivisions except the Guelph and Salina are $\pi$ ell exposed in the Niagara gorge, the Cataract red or grey sandstone and shale resting upon the red Queenston shale at the mouth of the gorge. As one follows up the gorge the Cataract beds disappear beneath the rapids, and afterwards the Medina is lost, so that at the falls the lowest rock visible is the Clinton limestone.

The Niagara (Lockport) limestone is thin at Queenston Heights, at the mouth of the gorge, but grows thicker as one approaches the falls, owing to the gentle southward dip of the beds.

Dr. Parks mentions the following fossils as common in the Niagara and lower formations of the Silurian. 


\section{GEOLOGY OF THE TORONTO REGION}

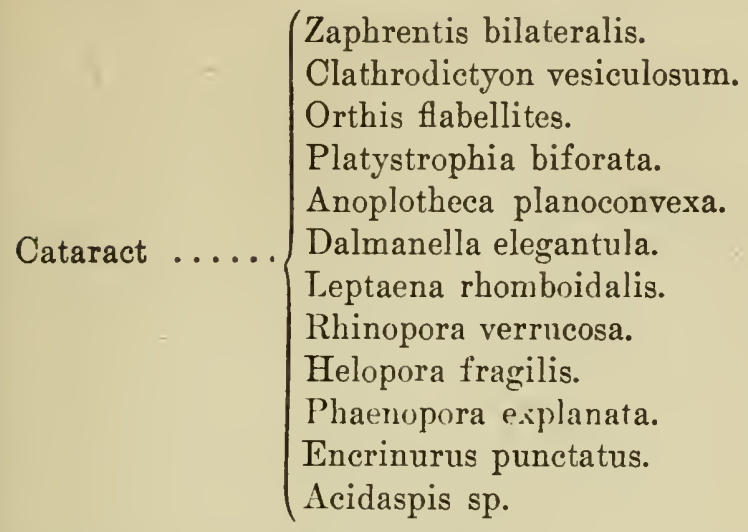

Medina ...... $\left\{\begin{array}{l}\text { Arthrophycus alleghaniensis. } \\ \text { Lingula cuneata. }\end{array}\right.$

Favosites niagarensis.

Halysites catenulatus.

Dictyonema retiforme.

Aulocopina granti.

Fenestella elegans.

Pachydictya crassa.

Clinton,

Rochester and

Spirifera niagarensis.

Lockport .....

Pentamerus oblongus.

Spirifera crispus.

Atrypa reticularis.

Whitfieldella (several species).

Rhynchotreta cuneata americana.

Caryocrinus ornatus.

Stephanocrinus angulatus.

Dawsonoceras annulatum americanum.

Bumastus ioxus.

Dalmanites limulurus. 
The lower sandstones and shales at Niagara are poor in fossils, but the Clinton, Rochester and Lockport beds contain a considerable fauna, the commonest species near the Falls being Spirifera niagarensis and Atrypa reticularis.

The Guelph dolomite should in reality be separated from the Niagara, since it differs so greatly in petrographic characters and in fauna from the lower members of the series. It nowhere appears in the escarpment, but may be seen in quarries near Guelph, Galt, Elora and other places on the tableland. The rock is yellowish and porous from the weathering out of fossils, which are numerous. The commonest forms are Megalomus canadensis and species of Murchisonia and Pleurotomaria. The fossils are generally large species as compared with the Niagara fossils in the beds below.

Coelocaulus (Murchisonia) macrospira.

Poleumita sulcata.

Conchidium (Pentamerus) occidentale.

Eotomaria galtensis.

Megalomus canadensis.

Pycnostylus galtensis.

Halysites catenulatus.

Trimerella grandis.

Whitfieldella hyale.

Calymene niagarensis.

The Salina, lying farther to the southwest, is not well displayed in Ontario, but is of importance 


\section{GEOLOGY OF THE TORONTO REGION}

because of its gypsum deposits near Paris and of its salt beds, which in a moist climate like that of Ontario cannot exist at the surface but are found beneath the Devonian rocks along Lake Huron and to the southwest at depths of several hundred feet below the surface. These beds furnish most of the salt used in the central provinces of Canada. In the State of New York an interesting fauna, including large examples of Eurypterus and Pterygotus, occurs in impure limestones of this age from which cement is manufactured, but the similar beds in Ontario have been little exploited.

Of the Devonian only the lower portion, the Onondaga (Corniferous), occurs in the region here described. It is found on the north shore of Lake Erie not far from Niagara Falls, as low outcrops of limestone with many thin layers of chert concretions. It is highly fossiliferous, many parts being practically coral reefs; and several species of coral may be collected in stone heaps in the fields or by the roadside. The commonest fossils are:

Cystiphyllum vesiculosum.

Favosites emmonsi.

Heliophyllum halli.

Syringopora hisingeri.

Streptelasma prolificum.

Michelinea convexa.

Atrypa reticularis.

Chonetes mucronatus.

Rhipidomella vanuxemi. 


\title{
NATURAL HISTORY, TORONTO REGION
}

\author{
Spirifera duodenarius. \\ Stropheodonta demissa. \\ Conocardium cuneus. \\ Paracyclas elliptica. \\ Platyceras carinatum. \\ Proetus rowi.
}

\section{PLEISTOCENE. \\ General Features.}

As previously mentioned, the greater part of the region under consideration is covered with drift deposits of the Pleistocene, sometimes to the thickness of 600 or 700 feet; and a very complex history has been worked out from them. Between the Deronian and the end of the Pliocene no record has been preserved, but it is certain that superficial erosion went on to a great extent in the long period of dry land conditions after the middle Palaeozoic. There was time to strip much of the Palaeozoic beds from the Archaean floor and to cut back for many miles toward the west and south the Silurian shales under their protective capping of Niagara limestone, thus producing the striking escarpment which crosses the province. Great river valleys were carved below the present level of the sea, showing that the land stood higher than now, the most important being the "Laurentian River," as it has been named by Dr. Spencer, which drained the Upper Lakes region through what is now Georgian Bay to the Ontario 


\section{GEOLOGY OF THE TORONTO REGION}

valley, which it entered near Toronto. Probably the Ontario basin did not then exist and the valley sloped eastwards toward the sea.

When the first record begins the surface possessed a higher relief than now, the escarpment rising as cliffs of 300 or 400 feet, and the old river valley at Toronto having a depth of at least 200 feet below the general level.

\section{Glacial Deposits.}

The greater part of the region is covered with glacial deposits, especially boulder clay, and moraines are frequent, sometimes rising as tumultuous hills as in the Oak Ridges north of Toronto, at others having low and inconspicuous forms. They have been worked out in much of the region by Mr. F. B. Taylor, but no general map of the glacial deposits has yet been published. With the moraines in various places there are kame deposits of coarse gravel and sand where sub-glacial rivers emptied, and in some cases narrow esker ridges of sand indicate the course of such rivers beneath the ice. The general surface of the boulder clay is apt to be gently rolling, as north of Toronto, but in some places there are drumlin hills of a more striking kind.

The boulder clay is charged with a great variety of stones, including Archaean rocks, such as granite, gneiss, diorite and crystalline limestone, and Palaeozoic rocks, such as limestones, shales and sandstones of the Ordovician. The matrix is commonly bluish 
grey clay, due to the grinding up of grey shales; but it becomes red or brown where the underlying rock is of that colour, e.g., over the Queenston shale, showing how local the source of the clay has been.

There are at least five sheets of boulder clay of different ages exposed in the vicinity of Toronto, but in most other parts of the lake region only one or two are to be found. The oldest tills are harder and more resistant to weathering than the later ones. The latest sheet is considered to have been formed by the Wisconsin ice sheet of American geologists. The oldest may be Pre-Kansan. It has not been possible to separate these till sheets with any certainty up to the present, except at Scarborough Heights, where almost the whole series is displayed.

The ice which covered the region came from the Labrador centre, but did not pass, as might have been expected, southwards or southwestwards across the country, since the valleys of the present Great Lakes deflected it into more westward directions. The ice followed these wide and deep depressions as great lobes, which were confluent when the glaciation was at its maximum, but which separated again when the ice sheets began to wane.

The ice sheets, after passing through the Ontario valley, spread out towards its western end and then climbed the escarpment, leaving polished and striated surfaces on the Niagara limestone beyond the cliffs. Striae and even deep gouges and grooves were left on the Devonian limestones around Lake Erie. 


\section{GEOLOGY OF THE TORONTO REGION}

The hills of Archaean rocks to the north of the Palaeozoic beds were powerfully scoured on the northeastern (stoss) side, showing roches moutonnées forms, but the lee side is often rugged and more or less covered with boulder clay or loose erratic blocks.

Some have supposed that the basins of the lakes were largely hollowed by the continental ice sheets, but it is improbable that any important amount of excavation was accomplished in this way. The damming of valleys by morainic materials was far more important and no doubt gave rise to the innumerable rocky lakes of the Archaean region to the north.

The heaping up of a great interlobate morainic mass between the valleys of Lake Ontario and Lake Huron blocked the channel of the ancient Laurentian River and deflected the waters round the southwestern peninsula of Ontario into Lake Erie and the Niagara River, thus changing the whole arrangement of land and water.

This land of irregular morainic ridges may be followed from a point near Trenton to Aurora, north of Toronto, and then to the top of the escarpment toward the west; while less conspicuous loops surround the southwestern end of the Ontario basin.

\section{Interglactal Periods.}

Between the sheets of boulder clay there are beds of stratified sand and clay evidently formed by water, and hence interglacial. The earliest of these inter- 


\section{NATURAL HISTORY, TORONTO REGION}

glacial episodes was long, and that it included great changes of climate and of physical conditions is proved by the extent and character of the deposits and by their fossils. This set of interglacial beds, which has been called the Toronto Formation, includes a thickness of 185 feet of sand and clay deposited as a delta by a great river flowing from the north into an interglacial Lake Ontario.

Three outcrops are of special interest, one at the Don Valley brickyard, another at Scarborough Heights, and a third near Christie and Shaw Streets. At the brickyard, which is just east of Rosedale, the lowest boulder clay is seen resting upon the Lorraine shale, followed by 25 feet of stratified clay and sand containing many shells and leaves of trees as well as logs of wood. Above this there are 21 feet of stratified clay with a little peaty matter, but no other organic remains. This is followed by a second sheet of boulder clay and then by 80 feet of stratified clay from which no fossils of any kind are known. Boulders on the Iroquois terrace above imply a third boulder clay removed by wave action.

The fossils from the Don valley interglacial section include a dozen species of the Unionidae, four of which now live in Lake Ontario, three others in Lake Erie, while the other five do not occur in Canada but are found in the Mississippi waters. There are in addition twenty-nine species of smaller shells. 


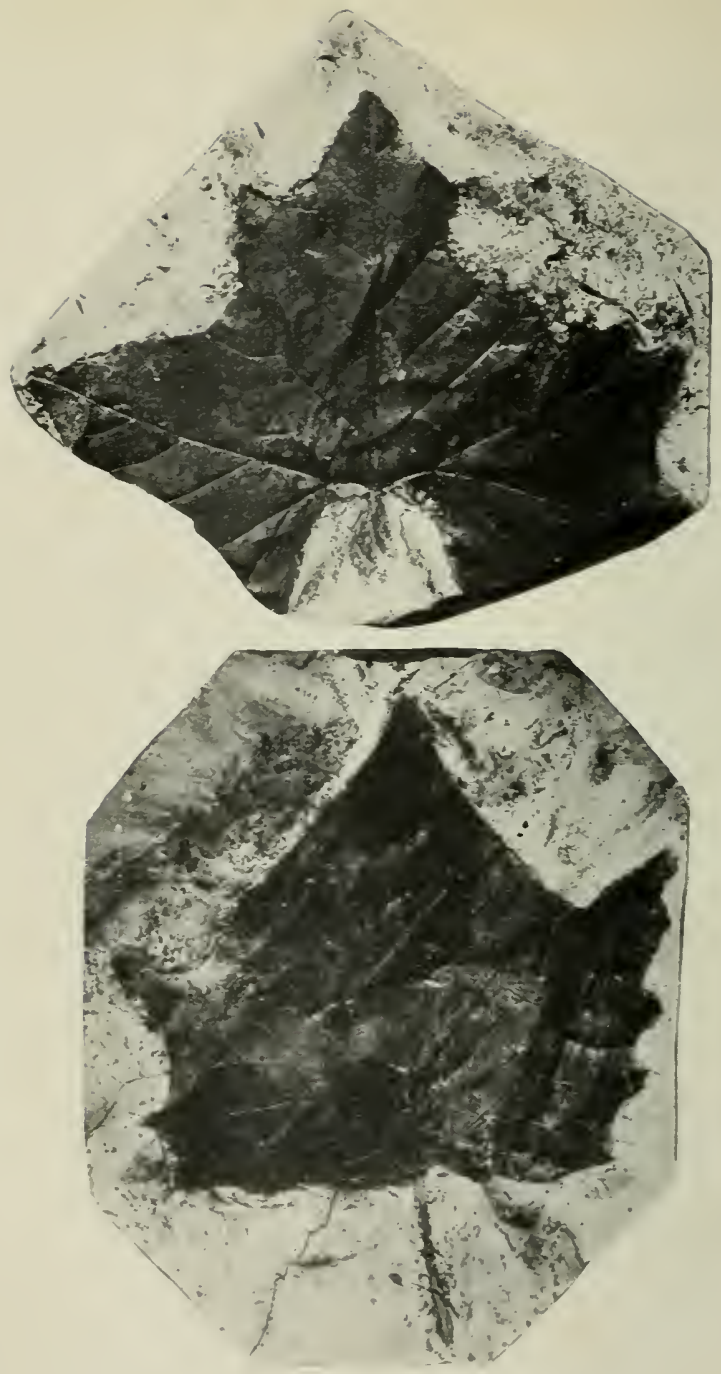

FOSSIL LEAVES (Interglacial), DON VALLEY.

A. P. Coleman.

l'hoto by J. II. W'lute. 


\section{GEOLOGY OF THE TORONTO REGION}

The leaves and wood belong to more than thirty species, which include Asimina triloba, Carya alba, Chamaecyparis sphaeroidea, Crataegus punctata, Juniperus virginiana, Maclura aurantiaca, Platanus occidentalis, Prunus, Robinia pseudo-acacia, Taxus canadensis, Thuja occidentalis, Tilia americana, and several species of ash, poplar, oak and elm, and two extinct species of maple. The whole assemblage of trees indicates a climate decidedly warmer than Toronto at present, about like that of Ohio or Pennsylvania.

The section at Scarborough Heights, some miles east of Toronto on the shore of Lake Ontario, includes 36 feet of sandy beds with unios and wood beneath the water level, 90 feet of peaty stratified clay, and 55 or 60 feet of stratified sand. The peaty clay encloses a little wood, fragments of leaves, mosses and seventy-two species of beetles, of which only two still live. The stratified sand contains wood and a few small shells. The fossils are considered to indicate a climate somewhat cooler than the present, like that of Lake Superior, for example. The Scarborough beds are evidently delta deposits laid down in a lake rising 150 feet higher than Lake Ontario. Later the lake was drained and valleys were cut in the delta by rivers, as may be seen at a striking bit of cliff architecture called the "Dutch Church." This is carved by rain and stream erosion from boulder clay which filled the old valley during the second ice advance. 
Above this sheet of boulder clay resting on the eroded surface of the delta there are three other layers of till with stratified sand or clay between, the whole reaching a thickness of two hundred feet. None of the upper interglacial beds seem of much importance compared with the earliest, the Torunto Formation.

At certain sand pits in western Toronto near Christie and Shaw Streets, a little north of Bloor Street, there are interglacial deposits of a quite different character, cross-bedded sand and gravel laid down by powerful currents. In these beds bones of bison, Cervalces borealis, and of mammoth or mastodon have been found, as well as ivory and a few shells. The relations of these sands to the other beds are uncertain, but they are undoubtedly interglacial.

Interglacial beds have been found at the Whirlpool, Niagara, near Dundas, at the head of Lake Ontario, and at some other points; but few or no fossils have been obtained from them, and it is not known whether they should be correlated with the Toronto Formation or not. There is some reason to believe that the Aftonian interglacial beds of Iowa, which have yielded Cervalces, as well as a number of other mammals, may be of the same age as the Toronto Formation.

Glacial Lakes.

Each advance of the ice must have ponded back the water before it in the present lake basins, but 


\section{GEOLOGY OF THE TORONTO REGION}

thus far no deposits formed in these interglacial lakes, except perhaps near Toronto, have been identified. Each retreat of the ice must also have been followed up by bodies of water whose outlet was blocked toward the east. The last ice retreat, that of the Wisconsin sheet, has left unmistakable evidence of a succession of glacial lakes which covered much of the region. Of these lakes two are of greatest importance-Lake Iroquois, which occupied the basin of Lake Ontario, but at a higher level; and Lake Algonquin, which covered most of the great upper lakes with a single vast sheet of water.

These ancient lakes have been somewhat carefully mapped, and their shores are as mature and often almost as well preserved as those of the present Great Lakes, though now, of course, covered with vegetation.

\section{LAKE Iroquois.}

The shores of Lake Iroquois, with their wave-cut cliffs and well-defined gravel bars, have been traced almost all round Lake Ontario, by Gilbert and Fairchild in New York, and by Spencer and Coleman in Ontario; but there is a wide gap at the north-east end of the basin, where no shore has been found. The shore in that quarter was of ice. Since the St. Lawrence outlet was blocked, Lake Iroquois emptied through the Mohawk Valley in New York into the Hudson. The beach is continuous except where cut by river valleys and at Scarborough 


\section{NATURAL HISTORY, TORONTO REGION}

Heights, where the waves of Lake Ontario have removed it for half a mile.

The old shore is deformed, rising 116 feet above Lake Ontario at Hamilton, 176 feet at Toronto, 385 feet at Trenton, and 495 feet on an island to the northeast of Trenton. It gives convenient routes for high roads and railroads, and sites for three cities, St. Catharines, Hamilton and Toronto. The last named city is, however, expanding beyond the old shore cliffs, spreading out on the upland of boulder clay to the morth. Fine gravel bars extend across the ancient river valleys, enclosing bays which are readily observed. The most striking of these bars runs like a wall northeast of Hamilton, cutting off a Dundas Bay of Lake Iroquois, as well marked as the modern Hamilton Bay, separated by a sand bar from Lake Ontario.

Two long bars occur at Toronto, one projecting westward from West Toronto, cutting off an old Humber Bay, the other extending two or three miles southwest from Scarborough Heights, forming an old Don Bay. The latter bar in shape and the arrangement of its lagoons resembles the present Toronto Island.

The belt of gently sloping shallow water deposits between the Iroquois beach and the shore of Lake Ontario is gencrally from two to five miles wide and provides some of the most valuable fruit lands in Canada, where apples, grapes and peaches are cultivated on a large scale. 


\section{GEOLOGY OF THE TORONTO REGION}

The shore deposits of Lake Iroquois at Hamilton and Toronto have a thickness of more than one hundred feet, and in the gravel bars remains of mammoth, caribou and other mammals, as well as frestwater shells, have been found. As the lake had one shore of ice the water must have been cooler, and probably the climate also, than that of the present Ontario valley.

Lake Algonguix.

Lake Algonquin, as worked out by Spencer, Taylor, Goldthwaite and others, was probably the greatest of the glacial lakes, including the basins of Lake Superior, Lake Nipigon, Lake Michigan, Lake Huron and Georgian Bay, and a large amount of the lowlands adjacent. Its outlet appears to have been first by Niagara River over Niagara Falls into Lake Iroquois, but later by the Trent Valley. Its beaches occur near London, Barrie and other points west and north of Toronto. They are even more strongly developed than those of Lake Iroquois, since the lake was larger and perhaps somewhat longer lived than the one in the Ontario basin.

\section{Niagara Falls.}

The history of Niagara Falls begins with the outflow of the Algonquin waters through the Erie valley and then northward over the Niagara escarpment into the basin of Lake Iroquois. The history of the falls has interested geologists ever since the 
visit of Sir Charles Lyell in 1842, and many papers have been written on the subject. The most important contributions to the literature have been made by Gilbert, Spencer and Taylor, who do not entirely agree as to the succession of events.

All agree that the falls began at the Niagara escarpment near Queenston on the Canadian side and Lewiston on the American when the ice of the Ontario lobe had so far withdrawn as to set free a large part of the basin. It is probable that the falls began as three separate plunges over the three harder rock layers of the escarpment, the Cataract sandstone, the Clinton limestone and the Niagara (Lockport) limestone. The upper limestone is the thickest and most resistant of the three beds, so that ultimately the two lower falls worked their way back to the upper fall, probably at Niagara Glen; since then there has been only one fall.

The Niagara gorge is 300 feet deep at Queenston Heights, but diminishes to 158 feet at the Canadian or Horseshoe Fall. Dr. Spencer has sounded below the falls, finding a depth of water of 192 feet, making a total depth of 340 feet for the chasm.

The width of the gorge varies to an important degree, having two stretches which are narrower than the rest, at Niagara Glen and just below the railway bridges, both accompanied by powerful rapids. These narrower portions may be accounted for by supposing the greater part of the drainage of the Upper Lakes to be diverted to the Trent Valley 


\section{GEOLOGY OF THE TORONTO REGION}

outlet or to the Mattawa-Ottawa outlet, leaving only the supply from the Erie basin to continue the work of cutting back, which then progressed much more slowly.

It has been determined by Dr. Spencer that, since accurate surveys have been made, the rate of recession of the Horseshoe Fall is 4.2 feet per annum, and that the shape of the rim has been greatly changed. The American Fall has a much smaller flow of water, about 7 per cent. of the whole, and ean scarcely handle the great blocks of rock which have tumbled from the cliff. Dr. Spencer estimates its recession at only 0.6 of a foot per annum.

If the falls have receded at the uniform rate of 4.2 feet per annum for a distance of $61 / 2$ miles, the time required would be about 8,000 years; but the times of much slower recession suggested above may greatly increase this estimate, and Dr. Spencer's figure, 39,000 years, is perhaps not excessive.

One of the most interesting points along the Niagara gorge is the Whirlpool, a mile below the railway bridges, where the river makes a complete loop, the entering current plunging under the escaping current. The cause of the sudden bend in the river channel and of its westward bulge is to be found in an old drift-filled channel which the falls discovered in the course of its recession and partially cleared out. The ancient stream was much smaller than the Niagara. 
The geological history of the region in Postglacial times begins with the removal of the remnants of ice which blocked the St. Lawrence outlet, when the water sank from the Iroquois stage to sea level for a time, though the great inflow of fresh water prevented the basin from becoming salt. Meantime, the region to the northeast was slowly rising and at length cut off the basin of Ontario from the Gulf of St. Lawrence, when Lake Ontario came into being. It probably fell far short of its present westward extension at first, but the differential elevation of its outlet at the Thousand Islands has backed up the water, which now stands 246 feet above the sea.

\section{THE SOILS OF THE TORONTO REGION.}

There are many rarieties of soil in the district surrounding Toronto, resulting from the events of Pleistocene times just detailed. Residual soils due to the decay of ancient rocks in place scarcely exist in the region, which is almost wholly covered with glacial drift or with old lake deposits. The glacial materials include certain moraines to the north so thickly strewn with stones as to be almost valueless to the farmer, a few kames of barren gravel, and some wide stretches of hopeless outwash sand, all practically useless when stripped of their forest growth; but they also supply the strong clay soils of the broad rolling surface of till covering much of the province, sometimes rather stony, but rich in lime, potash and phosphorus derived from the ground- 
up shale, limestone and Archaean rocks. These rich but somewhat heavy soils make the basis of the agriculture of southern Ontario, which is still the most productive province of Canada. The old lake bottoms of Iroquois and Algonquin origin afford also a great variety of soils of a somewhat different kind, mostly derived from the glacial deposits of their shores either by the action of waves or of rivers entering and forming deltas. Where the waves have eaten into promontories of boulder clay the enclosed boulders are sometimes left in the fields in hopeless numbers, but usually the lake-formed soils are free from stones. They range from the gravels of ancient bars, where the soil is thin and too well drained, into sandy slopes of very light soil, which merge lower down into sandy loam, and finally in the flatter parts form wide stretches of rich silty alluvium. The soils due to lake action have proved themselves excellently adapted for fruit growing, especially the sandy loams, so that the band of Iroquois deposits round Lake Ontario is largely covered with orchards and vineyards. There is probably no part of North America more favorable to mixed farming and fruit growing than the part of Ontario south of the Archaean region.

\section{GEOLOGICAL EXCURSIONS NEAR TORONTO.}

A number of excursions have been planned for the members of the Geological Congress in and near 


\section{NATURAL HISTORY, TORONTO REGION}

Toronto. For details in regard to them the special guide books prepared for the purpose should be consulted. Here it will merely be necessary to outline the possibilities.

One may visit several geologically interesting localities in Toronto or its vicinity by street-car combined with short walks, as follows:

The Don Valley Brickyard, showing Lorraine shales and glacial and interglacial beds with many fossils, may be reached by taking a Church Street car to Rosedale, and walking a mile, first north along Glen Road, then east on Binscarth Road, where a path leads down to the Don Valley and the brickyard.

The Sand and Gravel Pit on Shaw Street, showing crossbedded river deposits of interglacial age with manmoth, etc., may be reached by taking a Bloor car northwest to that street. A few minutes' walk to the north brings one to the pit, which is on the west side of the street.

Toronto Island, showing a modern sand and gravel bar built of materials transported from Scarborough Heights to the east, may be reached by taking a Yonge Street car to the waterfront on Toronto Bay. Ferries ply to the island a block to the west of Yonge Street.

Scarborough Heights, showing the finest Pleistocene section in Canada, ineluding 355 feet of glacial and interglacial beds, may be visited in two ways: first, by taking a King Street car as far east as pos- 
sible, turning south to the beach and walking east along the foot of the cliffs; or, second, by taking a King Street car to the Woodbine, and then a suburban car on Kingston Road to Stop 32. A lane leads two-thirds of a mile south to the cliffs.

Lambton Mills, to the northwest of Toronto, may be reached by taking a Dundas Street car to West Toronto and then a suburban car to Lambton Mills. An old gravel bar, belonging to the Iroquois beach, runs westwards almost to the Humber. South of Lambton Mills along the Humber River there are good exposures of Lorraine shale, and also for two miles up stream on the west side.

Excursions out of town may be made by C. P. R. northwards to Forks of the Credit, where there is an excellent Silurian and Ordovician section on the escarpment; and to Longford and Washago, or Parry Sound; or by G. T. R., C. P. R. or C. N. R. to Muskoka, where Archaean rocks are displayed.

One can go by rail or steamer to Hamilton, forty miles west of Toronto, where the Iroquois beach is finely displayed, and the escarpment exposes a Silurian section; and one can go east by C. N. R. or G. T. R. along the old Iroquois shore, with the hills of an interlobate moraine rising to the north.

One can cross Lake Ontario to the Niagara River and go by electric railway to the Niagara Gorge and Falls.

For details in regard to these excursions one is referred to the special guide books. 


\title{
CHAPTER IV.
}

\section{THE GLIMATE OF TORONTO.}

By

\author{
R. F. STUPART, F.R.S.C.,
}

Director Dominion Meteorological Service.

Toronto is situated on the north shore of Lake Ontario on a peninsula formed by the Great Lakes (Huron, including the Georgian Bay, Erie and Ontario). The land in this peninsula reaches an approximate height of 700 feet above the lake in a ridge which parallels the Ontario shore line at a distance of about twenty miles and then trends away to the northwestward, increasing to a height of 1500 feet just south of the Georgian Bay. These geographical features play an important rôle among factors affecting the climate of. Toronto.

An Observatory was established at Toronto in 1840, and meteorological observations have been taken continuously ever since. Up to 1907 there was practically no change in the location of the instruments, although as time went on the city grew up around the University property, within the boundaries of which the Observatory was placed. It was not, however, until 1906, that any building was erected near enough to impair the Observatory 


\section{THE CLIMATE OF TORONTO}

records, and shortly after this, in the spring of 1907 , the instruments were removed to a somewhat confined area half a mile distant, where they remained for eighteen months, until removed to the present Observatory in September, 1909. During two years prior to removal from the old site, comparisons were made with thermometers placed at the site now occupied, and very close agreement was found. In addition to this long series of observations at the Government Observatory, there was an almost unbroken series of observations by the Rev. Charles Dade, between 1830 and 1839 .

The Toronto Observatory, in addition to being the local meteorological observing station, is the central office of the Dominion Meteorological Service, whence are issued all weather forecasts and storm warnings and also all Government bulletins and reports, concerning the climatology of Canada.

The mean annual temperature, as determined from readings of the maximum and minimum thermometers during 71 years' observations, is $44^{\circ} .4$. The highest annual mean was $47^{\circ} .2$ in 1898 , and the lowest was $40^{\circ} .8$ in 1895 - a difference of $6^{\circ} .4$. The greatest difference between any two successive years was $3^{\circ} .8$ in 1882-3, and the least was $0^{\circ}$, in 1841-2.

The seasonal mean temperatures are: Winter, $23^{\circ} .4$; Spring, $41^{\circ} .0$; Summer, $65^{\circ} .8$; Autumn, $47^{\circ} .5$.

There are some indications that the climate has changed slightly with the gradual clearing away of 


\section{NATURAL HISTORY, TORONTO REGION}

the vast American forests. It would appear that both Summer and Autumn are a little warmer, and that Winter is colder than in the earlier days of settlement, while the Spring average temperature shows little or no change.

Considering the seasons from a popular standpoint, the writer believes that their duration might be stated as follows:

Spring-March 10th to May 20th. Summer-May 21st to September 10th.

Autumn-September 11th to November 25th.

Winter-November 26th to March 9 th.

The first part of March is usually rather cold, but days of bright sunshine and swelling buds, together with the rapid disappearance of the snow, which now lies only in patches in sheltered places, give omen of spring, which soon comes on apace. The maple tree has bloomed as early as March 20th, and a few hardy plants may occasionally be found in bloom ten days later. A few migrating birds will also appear after the middle of the month, and by the 31 st, when the ground exposed to the sun is usually free of frost, ploughing is frequently possible.

The months of March 1903 and 1910 showed the largest positive departures from average for months of that name, the latter especially being characterized by an extraordinary warm spell during the last week, when temperatures of over $70^{\circ}$ were recorded. 


\section{THE CLIMATE OF TORONTO}

The coldest March was that of 1885 , with a mean temperature of $18^{\circ}$, this following one of the coldest winters on record.

April is a month of much bright sunshine, which averages 193 hours, and the rainfall is less than in any other month of the year. Owing, however, to the position of Toronto upon the shores of Lake Ontario, winds off the lake, which in winter somewhat temper the climate, now ratard the upward trend of temperature, and vegetation makes rather slow progress. Up to the 20th light falls of snow may also occur, but this snow is quickly melted. After the 20th there is usually a marked improvement in the weather conditions, vegetation then making more rapid strides, and the swallows and insects become numerous. The date of seeding varies with the drying of the ground and will often be quite early in the month, but it is seldom general until the 20th. At this date, also, violets and a few other wild flowers are found in the woods, and elm and poplar are usually in bloom.

The three warmest Aprils were those of 1844, 1878 , and 1895 -that of 1878 was exceptionally warm, with a mean temperature of $49^{\circ} .2$, but $3^{\circ} .2$ lower than the temperature of a normal May. Occasionally very high thermometer readings are recorded towards the end of this month, the highest record being $89^{\circ} .9$ on the $22 \mathrm{nd}, 1842$.

May.-By the first of May the somewhat frequent cool periods, which retard growth in plant life 
during April, are now practically over, and with leaps and bounds regetation goes forward. By the 15th day most of the spring wild flowers are in bloom and many trees are in full leaf. About ten days later horse ehestnut, lilac and apple are in bloom, and incubation by migratory birds is well on the way. The average date of the last spring frost is May 4th. The warmest May on record was that of 1911, with a mean temperature of $61^{\circ} .2$, and the coldest that of 1867 , with a mean of $46^{\circ} .5$. It is not uncommon in this month for the daily maxima temperatures to exceed $70^{\circ}$ for spells of a week or ten days.

One of the outstanding features of the Toronto summer is the fact that wholly overcast and rainy days are of rare occurrence, the rainfall occurring in showers and thunderstorms, while days of bright sunshine are numerous; in fact, from the middle of June until the end of August one may almost count on days of at least part sunshine. There is an average of 791 hours of sunshine in the three months.

By May 20th the normal daily temperature has risen to $53^{\circ} .5$, with an average daily maximum of $64^{\circ}$ and occasional days of $80^{\circ}$. June has an average daily maximum of $72^{\circ}$, July $78^{\circ}$, and August $76^{\circ}$, and during the first ten days of September it is still above $70^{\circ}$. Spells of great heat occasionally occur, but temperatures of $90^{\circ}$ are not of frequent nccurrence. Up to 1911 the highest temperature ever recorded was $98^{\circ} .6$, but a period of heat during the first few days of July, 1911, broke all records, and 


\section{THE CLIMATE OF TORONTO}

on six consecutive days the following temperatures were registered: $98^{\circ}, 101^{\circ}, 103^{\circ}, 97^{\circ}, 95^{\circ}$ and $92^{\circ}$. The average warmest day of the year is July 15 th, but the normal changes very little between July 5 th and August 12th. The warmest summer on record was that of 1911 , with a mean of $68^{\circ} .8$; the warmest June was that of 1895 , with a mean of $67^{\circ} .9$; the warmest July that of 1868 , with mean of $75^{\circ} .8$, and the warmest August that of 1500 , with mean of $71^{\circ} .6$. The coolest summer was that of 1869 , with a mean of $62 .^{\circ} 2$, and in this summer the temperature was over $80^{\circ}$ on but five days.

The summer rainfall is quite evenly distributed, each month averaging a little under 3.00 inches. The greatest rainfall was 15.88 inches, in 1841, and the least was 1.95 inches, in 1899 . The heaviest monthly rainfall in summer was 8.15 inches, in July, 1841, and the least a trace in August, 1876. The heaviest falls ever recorded were 3.45 inches during a thunderstorm on the 4th August, 1878, and 3.88 inches during a 22-hour rain in July, 1897.

The downward trend of the temperature curve is not rapid during the autumn, and it is not until October 7 th that $50^{\circ}$ is reached, and November 26th is the average date on which mean temperature drops to the freezing point. The warmest autumn was that of 1908 , with a mean of $51^{\circ} .6$, and the next warmest, 1912 , with a mean of $51^{\circ} .2$, in each year the three months being above average. The warmest September was that of 1881 , with a mean of $67^{\circ} .8$; 
the warmest October that of 1900 , with a mean of $56^{\circ} .4$, and the warmest November that of 1902 , with a mean of $42^{\circ} .9$. The coldest autumn was that of 1873 , with a mean temperature of $43^{\circ} .5$.

On November 26th the normal mean temperature sinks below the freezing point and then gradually lowers until the minimum of the winter is reached, about February 4 th, of which the normal mean is $19^{\circ} .6$; from this onward the curve rises, at first slowly and then more rapidly, until on the 26th March it again crosses the $32^{\circ}$ mark. The normal Toronto winter is not then very severe, and extremely low temperatures are of infrequent occurrence, except in abnormal years.

The coldest winter was that of 1874-5, with a mean of $17^{\circ} .3$, and other exceptional winters were $1903-4$, with a mean of $17^{\circ} .4 ; 1904-5$, with a mean of $18^{\circ} .7 ; 1884-5$, with a mean of $18^{\circ} .3$. The mildest winter was that of $1889-90$, with a mean of $30^{\circ} .6$. Other very mild winters were $1877-8$, with a mean of $28.5 ; 1879-80$, with a mean of 28.8 ; 1881-2, with a mean of $29^{\circ} .3$, and 1905-6, with a mean of $28^{\circ} .2$.

The Decembers of 1881 and 1889, with a mean temperature of $34^{\circ} .3$, were the warmest on record, and that of 1911 , with a mean of $33^{\circ} .9$, was also unusually mild. The coldest Decembers were those of 1859,1872 and 1876 , with mean temperatures, respectively, $17^{\circ} .9,18^{\circ} .7$ and $17^{\circ} .2$. The highest temperature ever recorded in December was $56^{\circ} .2$ on 


\section{THE CLIMATE OF TORONTO}

the 14 th, 1901 , and the lowest $-21^{\circ}$ on the 21 st, 1871.

January and February have much the same mean temperature. February, 1875, was the coldest month on record, with a mean temperature of $10^{\circ} .2$. On fourteen consecutive days the temperature fell below zero, with an absolute minimum of 16 below; the mean minimum of the month was $-0^{\circ} .6$. Other notably cold months were Tanuary, 1866, with mean temperature of $16^{\circ}$; January, $1857,12^{\circ} .7$; January, $1875,16^{\circ} .1$; January, $1884,16^{\circ} .0$; February, $1885,11^{\circ} .1$; January, $1893,14^{\circ} .7$; January, $1904,16^{\circ} .0$, and January, $1912,13^{\circ} .9$.

The normal annual snowfall in Toronto is 65 inches. A few flurries usually occur in November, and occasionally several inches may fall, but it is not until December that the ground becomes snowcovered, and this, as a rule, not until well on in the month; there is not sleighing at Christmas in more than one year in five, and in many winters the ground is bare during Christmas week. During January and February there is usually sleighing, but towards the end of February the snow melts fast, and it is only occasionally that the surrounding country is snow-covered into March. Heary snowfalls have occurred in some years in March, but these are the exception rather than the rule, and an old and very prevalent idea that a heavy snowstorm usually occurs about March 17th is not borne out by the records. The heaviest snowfall on record is 16 inches, and this has occurred on several occasions. 


\section{NATURAL HISTORY, TORONTO REGION}

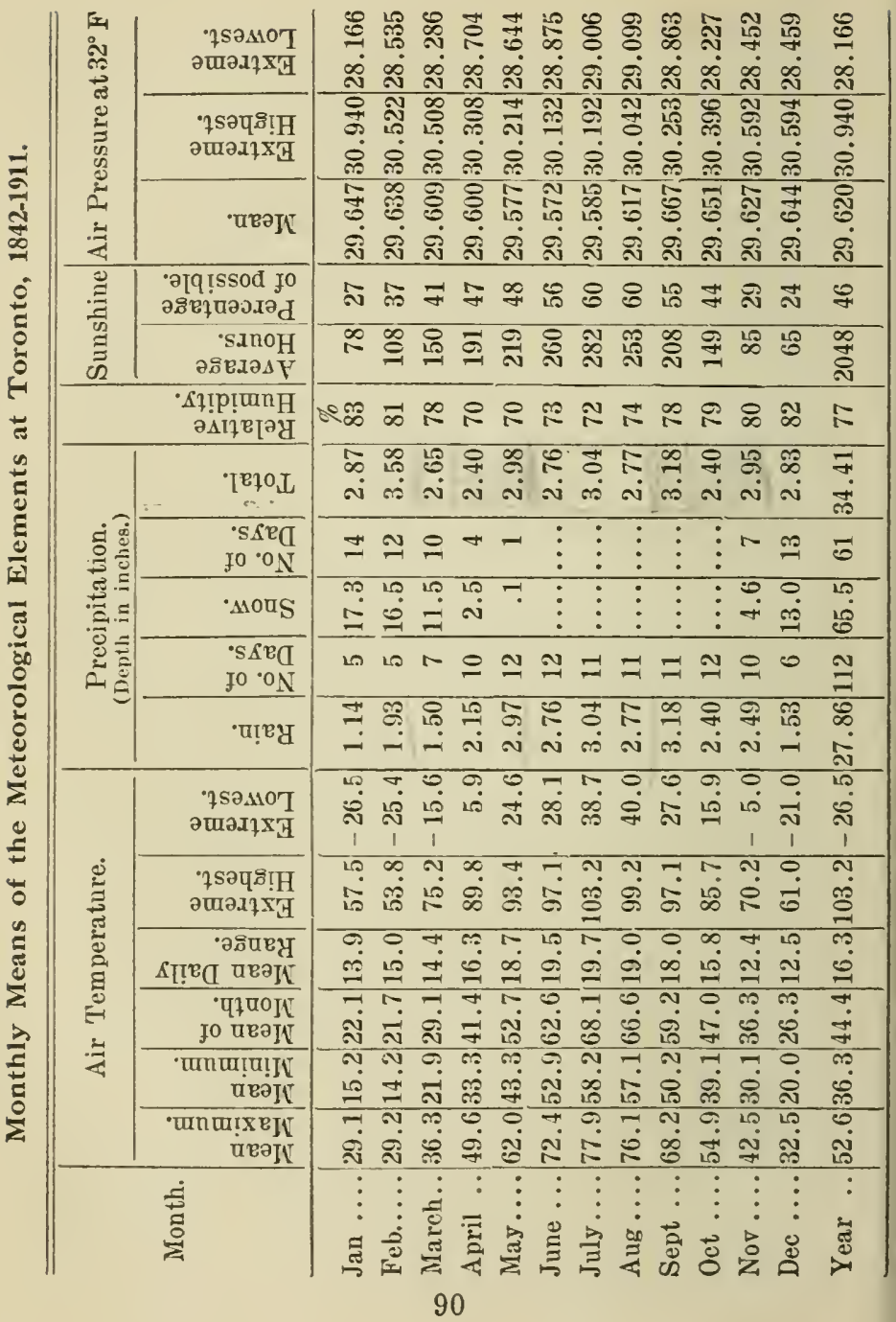




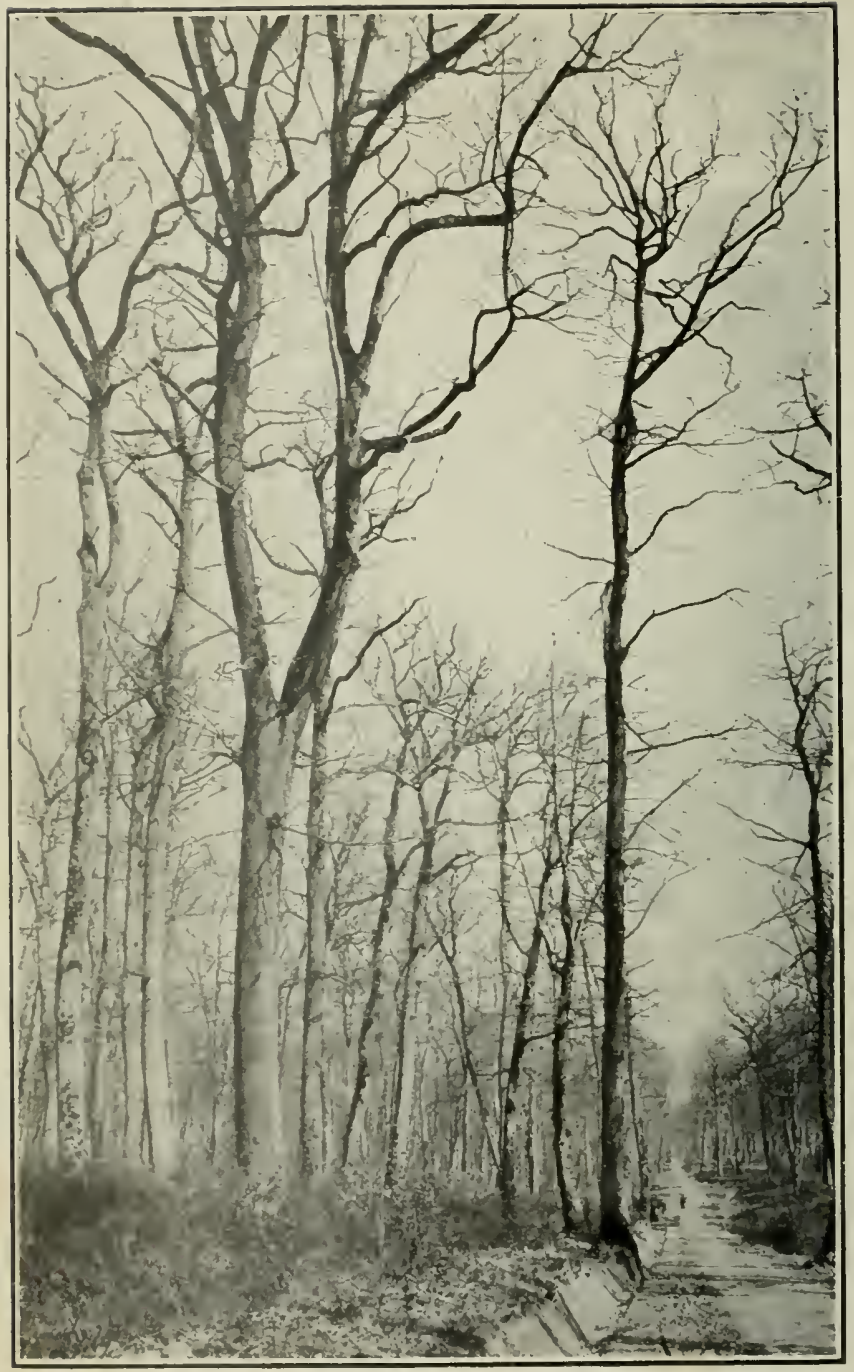

TYPICAL SOUTHERN ONTARIO HARDWOODS.

Courtesy of B. F, Fernow. 


\section{CHAPTER V.}

\section{LIFE ZONES.}

By

C. D. HOWE, Ph.D.

Is approaching Toronto from the United States either by the way of Buffalo or Detroit, one finds himself, immediately upon crossing the international boundary, in the Carolinian Area of the Upper Austral Zone of Merriam. The northern boundary of this area may be approximately made by drawing a line from the mouth of the St. Clair River through London to Hamilton, and thence along the lake shore to Toronto. Both the mean annual temperature and the average temperature of the four growing months are slightly higher than the average for the southern portion of the province. The rainfall is somewhat greater and the snowfall is considerably less than the average for the province.

The milder climate of the southwestern portion of Ontario has resulted in the projection of the flora of the lowland portions of the Southern States into Canada, as is disclosed by the presence of such trees as: the tulip-tree (Liriodendron tulipifera) ; chestnut (Castanea dentata); black walnut (Juglans nigra); sour gum (Nyssa sylvatica); mockernut hickory (Hicoria alba); Kentucky coffee-tree (Gym- 


\section{NATURAL HISTORY, TORONTO REGION}

nocladus dioicus); Judas-tree (Cercis canadensis); sassafras (Sassafras sassafras); honey locust (Gleditschia triacan'hos) ; papaw (Asimina triloba), and flowering dogwood (Cornus florida).

The original forest, however, was doubtless made up chiefly of oaks, hickories, maple, beech, basswood and elm, with the trees mentioned above as secondary species. Since the soil was of fine agricultural quality, the forest has almost entirely given way to farms. One is urged to visit Rondeau Park if he wishes to see a magnificent remnant of the forest type that originally covered the area.

The southern relationship of the flora is also strikingly shown by the herbaceous forms. Probably fifty species or more, many of them ranging as far south as Florida, are found in Canada only in the region described above. Among these may be mentioned: Rue anemone (Ranunculus thalictroides); corydalis (Corydalis flavula); mouse-ear cress (Sisymbrium thalianum); swamp saxifrage (Saxifraga pennsylvanica); Indian physic (Gillenia trifoliata); wild indigo (Baptisia tinctoria); wild lupine (Lupinus perennis); hoary pea (Tephrosia virginiana); tick trefoil (Desmodium pauciflorum); bush clover (Lespedeza virginica); Carolina vetch (Vicia caroliniana); flax (Linum virginianum); milkwort (Polygala sanguinea); flowering spurge (Euphorbia corollata); swamp rose mallow (Hibiscus moscheutos); great pinweed (Lechea villosa); loose-strife (Lythrum alatum); harbinger of spring 


\section{LIFE ZONES}

(Erigenia bulbosa); purple milkweed (Asclepias purpurascens); green milkweed (Acerates floridana); ground pink (Phlox subulata); waterleaf (Hydrophyllum appendiculatum); bluebells (Mertensia virginica); puccoon (Lithospernum gmelini) ; basil (Pycnanthemum flexuosum); ground cherry (Physalis virginiana); purple foxglove (Gerardia purpurea); tall bluebell (Campanula americana); blazing star (Liatris cylindracei $i$ ).

The Carolinian Area corresponds to the Lacustrine Area, Alleghanian-Ozark District of Die Vegetation der Erde of Engler and Drude. It lies within the Broad-leaved Summer Forest of Schimper; the Deciduous Dicotylous Forest of Warming; the Chestnut Zone of Mayr.

In approaching Toronto from Montreal one passes through the Alleghanian Area of the Transition Zone of Merriam. The northern boundary of the area is approximately formed by a line drawn from Ottawa to the southern portion of Georgian Bay. The area represents a transitional region from the prevailing needle-leaved forests of the north to the prevailing broad-leaved forests of the south, and its forests are consequently of mixed composition. Over the greater part of the area, however, the needle-leaved forests. and the broad-leaved forests occupy distinct sites. The needle-leaved forest, according to the situation in which it occurs, may be divided into two types; the white pine-red pine type and the coniferous swamp type. 
The white pine-red pine type within the area has been practically all removed by lumbering operations and its powers of reproduction greatly reduced by repeated fires, so that its sites are now chiefly occupied by poplar (mostly Populus grandidentata) and paper birch (Betula alba var. papyrifera). The original forest occupied the thin soils covering the granites and crystalline limestones and the deeper gravelly or sandy glacial and post-glacial deposits. The ground cover of the few stands of pine that remain is usually composed of the following species in order of their abundance: Trintergreen (Gaultheria procumbens) ; bracken fern (Pteris aquilina); blueberry (Vaccinium canadense and Vaccinium pennsylvanicum); bunch-berry (Cornus canadensis); bush honeysuckle (Diervilla lonicera); beaked hazelnut (Corylus rostrata) ; pipsissewa (Chimaphila umbellata); partridge-berry (Mitchella repens); wild sarsaparilla (Aralia nudicaulis); trailing arbutus (Epigaea repens).

The trees of the coniferous swamp type are: Balsam (Abies balsamea); arbor vitae (Thuja occidentalis); black spruce (Picea mariana) and larch (Larix laricina). They occur in various mixtures. Any of the first three mentioned may often predominate, and more rarely the last. Among the more characteristic subordinate plants of this type may be mentioned: Mountain holly (Nemopanthus mucronata); winterberry (Ilex verticillata); chokeberry (Pyrus arbutifolia); cotton grass (Eriophorum vir- 


\section{LIFE ZONES}

ginicum) ; cinnamon fern (Osmunda cinnamomea); small cranberry (Vaccinium oxycoccus); pitcher plant (Sarracenia purpurea); manna grass (Glyceria canadensis); orchid (Habenaria hyperborea); and sphagnum moss.

The broad-leaved forest occupies the deep glacial drift soils, which for the most part are gravelly or sandy loams. It is usually found on the higher slopes and ridges when these are well covered with soil, but it may occur on sandy flats when the water table is near the surface. At least one-half of the forest is composed of sugar maple (Acer saccharum), and about one-fourth consists of beech (Fagus grandiflora). The other species in order of their abundance are: Basswood (Tilia americana); yellow birch (Betula lutea); hemlock (Tsuga canadensis); hop hornbeam (Ostrya virginiana); elm (Ulmus americana); white ash (Fraxinus americana); balsam (Abies balsamea); black cherry (Prunus serotina); large-toothed aspen (Populus grandidentata).

The names of some of the characteristic plants which may be found beneath the broad-leaved forest are given below: Prickly gooseberry (Ribes cynosbati); witch hazel (Hamamelis virginiana); striped maple (Acer pennsylvanicum); round-leaved dogwood (Cornus circinata); witch hobble (Viburnum alnifolium); wood fern (Aspidium spinulosum); wood rush (Luzula vernalis) ; yellow clintonia (Clintonia borealis); false Solomon's seal (Smilacina racemosa); wild lily of the valley (Mianthemum 
canadense); large flowered trillium (Trillium grandiflorum); hepatica (Hepatica triloba); cohosh (Actaea rubra); false miterwort (Tiarella cordifolia); bishop's cap (Mitella diphylla); blue violet (Viola cucullata); black snakeroot (Sanicula marylandica).

A mixed broad-leaved-needle-leaved forest frequently occurs on the flats and bases of slopes along streams and lakes, and sometimes on low ridges rising above the pure broad-leaved forest. Hemlock is the principal needle-leaved tree in these situations, and while it may occur in greater proportion, it usually forms about one-third of such stands. Sugar maple and beech make up another third, while the remaining members are yellow birch, balsam, basswood, hop hornbeam, arbor vitae, black spruce and white ash, in order of their abundance. The herbaceous flora does not differ essentially from that of the pure broad-leaved forest.

Another mixed type is to be found in the drained swamps along the margins of slow-moving streams. In composition it is about one-third each of arbor vitae and black ash (Fraxinus nigra). The other third consists of balsam, hemlock, yellow birch, black spruce, maple, and elm. The herbaceous flora is a mixture of that of the broad-leaved forest and that of the coniferous swamp.

Along the railways from Montreal to Toronto forests of the types described above can be seen only in patches, for they have been chiefly supplanted by 


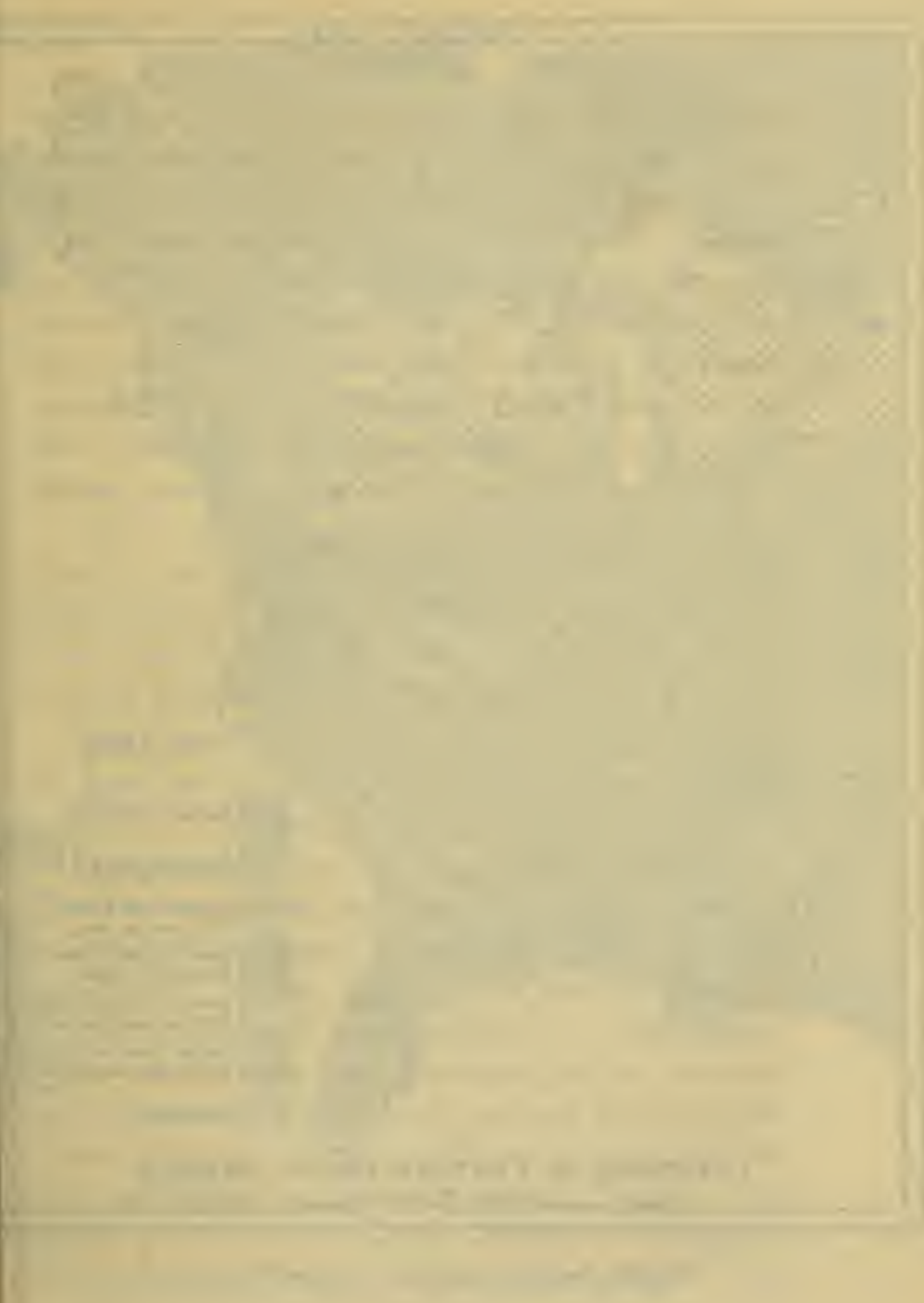




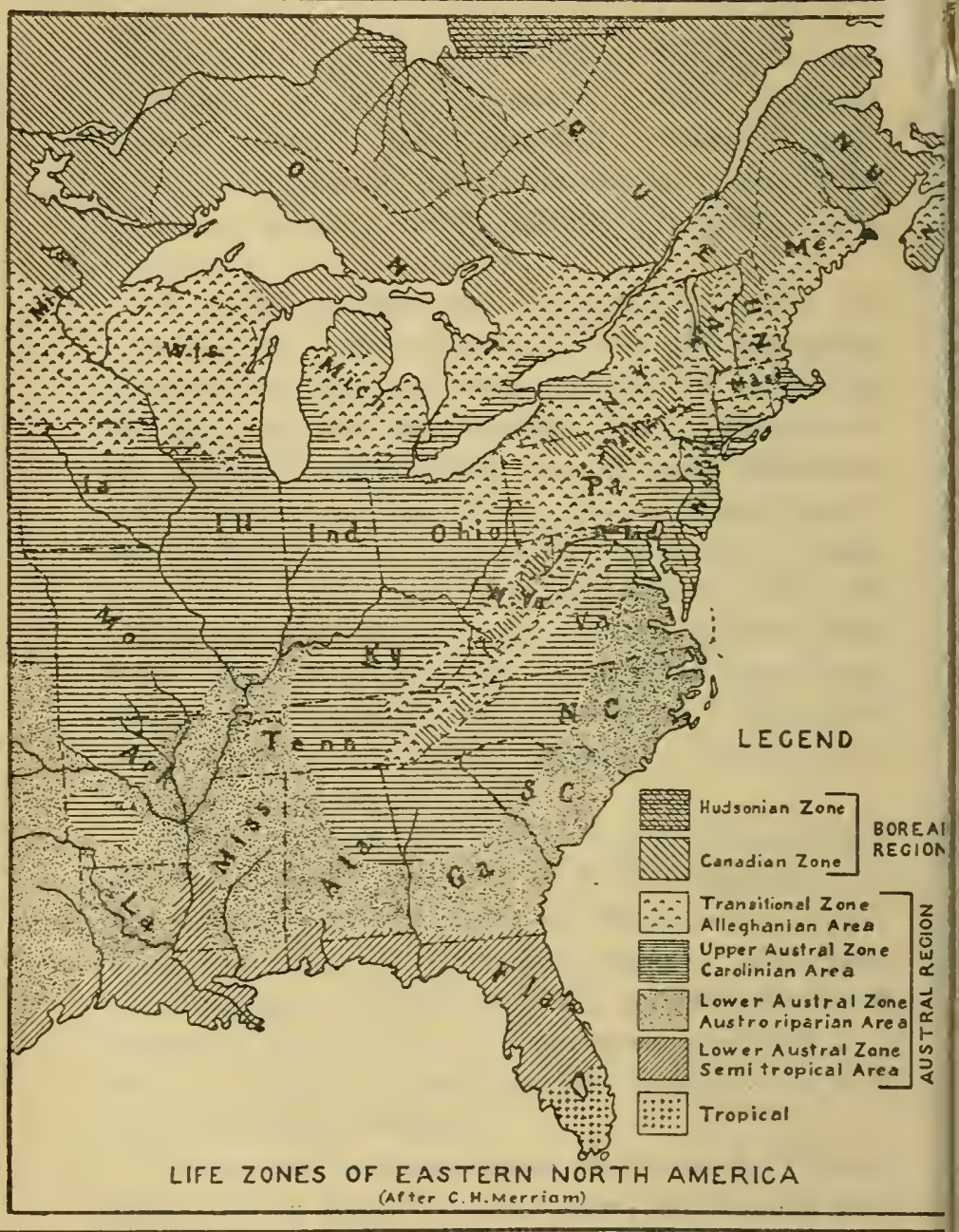

This Map has been prepared by J. Patterson, M.A. 


\section{LIFE ZONES}

farms, to a less extent, however, along the Canadian Pacific than along the Grand Trunk Railway. Along the former, especially between Montreal and Havelock, Ontario, one sees many illustrations of the poplar-birch type arising on burned areas, together with patches of the characteristic broad-leaf and coniferous forest types. Along the latter one sees only small remnants of the original maple-bcech forests in the farm wood-lots, with frequent cedar swamps on the heavier, poorly-drained soils.

The Alleghanian Area as described above corresponds to the Lake District of the St. Lawrence-Great Lakes Region of Engler and Drude. With reference to the other authors, they place it in the same classes as given above under the Carolinian Area.

The Canadian Zone lying north of the Alleghanian Area, as shown on the accompanying map, has a forest in its southern portion similar to that of the Alleghanian Area, but as one goes northward the broad-leaf component becomes smaller and the needleleaf component larger, as is shown by the greater abundance of balsam, white spruce, and black spruce. The white pine and red pine decrease in abundance. When the Hudson Bay drainage area is reached, sugar maple, beech, white ash, red oak will be found to have dropped out, and the forest becomes prevailingly coniferous, with black spruce forming the greater portion, sometimes two-thirds, of the stands. White spruce and balsam become minor species. The 


\section{NATURAL HISTORY, TORONTO REGION}

broad-leaf component is represented by poplars, and they often constitute one-fourth of the forest.

As has been shown in the article (p. 51) by Professor Coleman on the geology of the region, the city of Toronto for the most part stands on light sandy soils deposited in the Iroquois stage of Lake Ontario, and the regetation is characteristic of such soils. The trees are mostly oaks and pines. There are, however, patches of heavier soils, and where their forest remains it is composed of beech and hemlock, notably in Ashbridge's woods in the eastern part of the eity. North of the old Iroquois beach the soil gradually becomes heavier, with an increasing clay content, and the oak-pine forest is replaced by a maple-beech forest.

On the western edge of the city, in High Park and on the Humber plains, the regetation is distinctly Carolinian in its relationships, while on the eastern side it is Alleghanian, the city being the dividing line between the two types of flora. The transition between the two types is very abrupt in High Park, where one may pass in a few minutes from the Carolinian of the sand plains to the Alleghanian in the bottom of the deep ravines.

Toronto and vicinity offer excellent opportunities for the study of regetation in its various habitats; in fact there are few places where one can find on so small an area so many abrupt changes in the character of vegetation due to variations in soil and in the micro-climatic conditions. One interested in such 


\section{LIFE ZONES}

study is urged to visit the sand plains of the Humber River, the flood plains and ravines of the Humber and Don, the marshes near the mouth of the Humber and those along Ashbridge's Bay, the beach at Toronto Island, Scarborough Bluffs, the clay regions north and east of the Iroquois beach line, and the peat bog's at Bond Lake. 


\section{CHAPTER VI.}

\section{THE SEED PLANTS OF TORONTO AND VICINITY.}

By

PRINCIPAL WILLIAM SCOTT.

Toronto has a great variety of soil and surface. The soil varies from the purest of sand to the heaviest of clay. The Island, which faces the city, is composed of almost pure sand; the valleys of the Don and the Humber are almost pure clay. In the immediate vicinity of the city are to be found cold bogs and swamps.

The elevation of the land above the sea level varies from 250 feet at the lake front to 577 feet at the Forest Hill station on the Belt Line railway, and 817 feet at Richmond Hill. These conditions combine to produce a great variety of flowering plants. It is needless to say that man and the domestic animals have destroyed many plants that at one time were abundant here. Many rare and beautiful species that formerly flourished on the Island are, if not entirely extinct, rarely to be met with. "Ladies' tresses " conld always be found in abundance. The cxact locality where they were so common is now several feet under the sand which was purnped over the land to raise it. The only locality in which 
Scleria verticillata was known to grow has been "improved" so that this rare plant is now extinct. A few years ago both the valleys of the Humber and the Don were the homes of many varieties of Orchids and rare plants, as Ginseng and the Painted Cup. These have disappeared. May not unwise methods of teaching Nature Study have contributed to this unfortunate result to some extent?

In the flora of Toronto and its immediate neighborhood there are 104 families, 398 genera and 798 species enumerated in the accompanying list.

The following is a fairly complete list of the Phanerogamia found near Toronto.

\section{Taxaceae (Yew Family).}

Taxus canadensis, Marsh (Ground Hemlock). Rather rare. Don Valley. Also in interglacial Don Valley deposits.

\section{Pinacae (Pine Family).}

Pinus resinosa, Ait. (Red Pine).

" strobus, L. (White Pine).

" sylvestris, L. (Scotch Pine). Introduced.

" laricio austriaca, Endl. (Austrian Pine). Introduced.

Larix decidua, Mill. (European Larch). Introduced. " laricina, Koch. (American Larch or Tamarack). Infrequent in the immediate neighbourhood, but abundant in swamps within easy reach in every direction. 
Picea abies, Karst. (Norway Spruce). The most commonly planted ornamental spruce. Introduced.

" canadensis, BSP. (White Spruce).

" mariana, BSP. (Black Spruce).

Abies balsamea, Mill. (Balsam Fir). Almost absent within a ten-mile radius, but abundant to the north. Practically at its southern limit here in lowlands.

Tsuga canadensis, Carr. (Hemlock). Very common. Thuja occidentalis, L. (White Cedar). Abundant. Juniperus communis, L. (Common Juniper). Rare.

\section{Trphaceae (Cat-tail Family).}

Typha angustifolia, L. (Narrow-leaved Cat-tail). Grows plentifully on Toronto Island. " latifolia, L. (Common Cat-tail).

\section{Sparganiaceae (Bur-reed Family).}

Sparganium eurycarpum, Engelm. (Bur-reed). " simplex, Huds.

\section{Najadaceae (Pondweed Family).}

Potamogeton americanus, C. \& S.

" amplifolius, Tuckerm.

" crispus, L.

" filiformis, Pers.

" heterophyllus, Schreb.

"lucens, $\mathrm{L}$.

"natans, L. 


\section{THE SEED PLANTS OF TORONTO}

Potamogeton pectinatus, L.

$\begin{array}{ll}\text { “ } & \text { perfoliatus, L. } \\ \text { " } & \text { praelongus, Wulf. } \\ \text { " } & \text { pusillus, L. } \\ & \text { zosterifolius, Schumacher. }\end{array}$

Most of these species grow in Ashbridge's Bay; and several in Howard Lake.

Zannichellia palustris, L. (Horned Pondweed). Najas flexilis, Rostk. Found in abundance in still water.

\section{Joncagixaceae (Arrow Grass Family).}

Scheuchzeria palustris, L. Grows on the Island. Triglochin maritima, L. (Arrow Grass).

" palustris, L. Both species grow on the Island.

\section{Alismaceae (Water-plantain Family).}

Sagittaria arifolia, Nutt. Toronto Island and Bond Lake.

“ graminea, Michx.

" heterophylla, Pursh. Toronto Island.

“ latifolia, Willd. (Arrow-Head).

Alisma plantago-aquatica, L. (Water Plantain).

\section{Hydrocharitaceae (Frog's Bit Family).}

Elodea canadensis, Michx. (Water Weed). Howard Lake and Toronto Island. 


\section{NATURAL HISTORY, TORONTO REGION}

Vallisneria spiralis, L. (Tape Grass, Eel Grass). Both genera are common around the Island.

\section{Gramineae (Grass Family).}

Andropogon furcatus, Muhl.

" scoparius, Michx. (Beard Grass). Both

species are common in High Park.

Sorghastrum nutans, Nash. (Wood Grass). Found in

High Park.

Digitaria humifusa, Pers.

" sanguinalis, Scop. (Crab Grass).

Panicum capillare, L. (Old-witch Grass).

" depauperatum, Muhl.

" dichotomum, L.

" miliaceum, L. (European Millet). Introduced.

“ virgatum, L. (Switch Grass). Several clumps grow on the Island.

" xanthophysum, Gray.

Echinochloa crusgalli, Beauv. (Barnyard Grass).

Setaria glauca, Beauv. (Foxtail).

" italica, Beauv.

" verticillata, Beauv. In waste places in the city.

" viridis, Beauv.

Cenchrus tribuloides, L. (Bur Grass). At York on Grand Trunk Railway.

Zizania palustris, L. (Indian Rice, Water Oats). Leersia oryzoides, $\mathrm{Sw}$. (Rice Cut-grass). 


\section{THE SEED PLANTS OF TORONTO}

Leersia virginica, Willd. (White Grass).

Anthoxanthum odoratum, L.

Phalaris arundinacea, L. (Reed Grass). Introduced. " canariensis, L. (Canary Grass). Introduced.

Hierochloë odorata, Wahlenb.

Milium effusum, L.

Oryzopsis asperifolia, Michx.

" pungens, Hitchc.

Muhlenbergia mexicana, Trin.

66

66 racemosa, BSP.

sylvatica, Torr.

Brachyelytrum erectum, Beauv.

Phleum pratense, L. (Timothy). Introduced.

Alopecurus geniculatus, var. aristulatus, Torr.

Sporobolus cryptandrus, Gray. On Island.

" heterolepis, Gray.

" vaginiflorus, Wood.

Agrostis alba, L. (Red Top).

" alba var. vulgaris, Thurb.

" hyemalis, BSP.

" perennans, Tuckerm.

Calamagrostis canadensis, Beauv. (Blue-joint Grass). Ammophila arenaria, Link. (Beach Grass). Rare, but found on the Island.

Cinna arundinacea, L.

" latifolia, Griseb.

Holcus lanatus, L. (Velvet Grass).

Deschampsia flexuosa, Trin. (Common Hair Grass). Avena fatua, L.

" sativa, L. Introduced. 
Danthonia spicata, Beaur.

Arrhenatherum elatius, Beauv. (Oat Grass).

Phragmites communis, Trin. Plentiful on the Island.

Eragrostis hypnoides, BSP.

" minor, Host.

Dactylis glomerata, L. (Orchard Grass).

Poa annua, L. (Low Spear Grass).

“ compressa, L. (Canada Blue Grass).

" debilis, Torr.

" nemoralis, $\mathrm{L}$.

" pratensis, L. (June Grass).

" triflora, Gilib.

" trivialis, $\mathrm{L}$.

Glyceria fluitans, R. Br.

" nervata, Trin.

Festuca elatior, L. (Meadow Fescue).

" ovina, L. (Sheep's Fescue).

Bromus ciliatus, $\mathrm{L}$.

" kalmii, Gray.

" racemosus, $\mathrm{L}$.

“ secalinus, L. (Chess).

Lolium perenne, L. (Common Darnel).

Agropyron caninum, Beaur. (Awned Wheat Grass). repens, Beanv. (Couch Grass).

Hordeum jubatum, L. (Squirrel-tail Grass).

" sativum, L.

Elymus arenarius, $\mathrm{L}$.

“ canadensis, $\mathrm{L}$. 
Hystrix patula, Moench. (Bottle-brush Grass). Common in High Park.

\section{Cyperaceae (Sedge Family).}

Cyperus aristatus, Rottb. Found on the Island.

" diandrus, Torr. Found on the Island.

" esculentus, L. Found on the Island.

" schweinitzii, Torr. Found on the Island.

" strigosus, L. Found on the Island.

Dulichium arundinaceum, Britton.

Eleocharis acicularis, R. \& S.

6

obtusa, Schultes.

“ palustris, R. \& S.

" tenuis, Schultes.

Scirpus americanus, Pers.

atrovirens, Muhl.

“ debilis, Pursh.

" fluviatilis, Gray.

“ sylvaticus, L.

“ validus, Vahl.

Scleria verticillata, Muhl. Formerly common on the Island.

Carex aquatilis, Wahlenb.

" aurea, Nutt.

“ deweyana, Schwein.

" eburnea, Boott.

" flava, L.

" gracillima, Schwein. 


\section{NATURAL HISTORY, TORONTO REGION}

Carex granularis, Muhl.

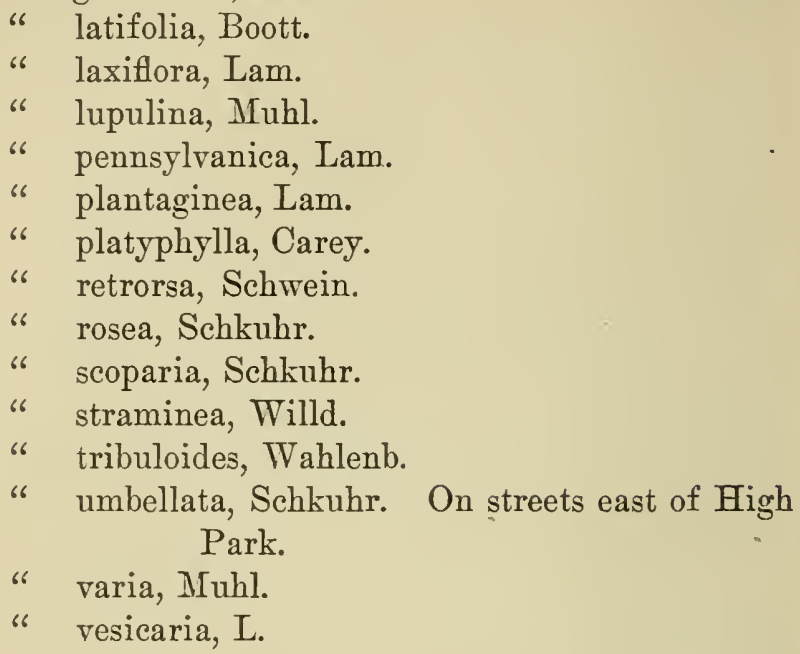

Araceae (Arum Family).

Arisaema triphyllum, Schott. (Indian Turnip). Calla palustris, L. (Water Arum). Grows near Grenadier Pond. Symplocarpus foetidus, Nutt. (Skunk Cabbage). Found in wet places around the city. Acorus calamus, L. (Sweet Flag).

\section{Lempaceae (Duckweed Family).}

Lemna minor, L. (Duckweed).

" trisulca, L. (Duckweed).

Wolffia punctata, Griseb. Grows in Grenadier Pond. 


\section{THE SEED PLANTS OF TORONTO}

\section{Ponteneriaceat (Pickerel-weed Family).}

Pontederia cordata, L. (Pickerel-weed). Grows near Grenadier Pond.

Heteranthera dubia, MracMr. Grows on the Island.

\section{Juncaceae (Rush Family).}

Juncus articulatus, L.

" balticus, Willd.

" bufonius, L.

" canadensis, J. Gay.

" effusus, L. (Common Rush).

" nodosus, L.

" tenuis, Willd.

Luzula campestris, DC. (Wood Rush).

" saltuensis, Fernald. Common on the steep banks of the Don.

\section{LiLiaceae (Lily Family).}

Tofieldia glutinosa, Pers.

Zygadenus chloranthus, Richards. Grows at Mt. Dennis.

Uvularia grandiflora, Sm.

" perfoliata, L. (Bellwort).

Allium tricoccum, Ait. (Wild Leek).

Lilium canadense, L. (Wild Yellow Lily).

“ philadelphicum, L. (Wild Orange-red L.)

" tigrinum, Ker. (Tiger L.) Introduced.

Erythronium albidum, Nutt. (White Dog's-tooth Violet). Grows in the Humber Valley. 


\section{NATURAL HISTORY, TORONTO REGION}

Erythronium americanum, Ker. (Yellow Adder'stongue).

Ornithogalum umbellatum, L. (Star of Bethlehem). Introduced.

Asparagus officinalis, L. Escaped from cultivation. Clintonia borealis, Raf. Common at Mount Dennis. Smilacina racemosa, Desf. (False Spikenard).

" stellata, Desf.

Maianthemum canadense, Desf.

Streptopus roseus, Michx. (Twisted Stalk).

Polygonatum biflorum, Ell. (Solomon's Seal).

Convallaria majalis, L. (Lily of the Valley). Introduced.

Medeola virginiana, L. (Indian Cucumber Root).

Common in woods west of city.

Trillium erectun, L.

" grandiflorum, Salisb.

" undulatum, Willd. (Painted Trillium).

Smilax herbacea, L. (Carrion-flower).

" hispida, Muhl. Both species grow in the Humber Valley.

\section{IrIdACEAE (Iris Family).}

Iris versicolor, L. (Blue Flag).

Sisyrinchium angustifolium, Mill. (Blue-eyed grass).

Orchidaceae (Orchid Family).

Cypripedium hirsutum, Mill. (Showy Lady's Slipper).

parviflorum, Salisb. (Smaller Yellow L.). 


\section{THE SEED PLANTS OF TORONTO}

Cypripedium parviflorum pubescens. (Larger Yellow L.).

Orchis spectabilis, L. (Showy Orchis).

Habenaria clavellata, Spreng.

" flava, Gray.

" hyperborea, R. Br.

" orbiculata, Torr.

“ psycodes, Sw.

Z Serapias helleborine, L. Plentiful in High Park and Don Valley.

Spiranthes cernua, Richard (Ladies' Tresses). Epipactis pubescens, A. A. Eaton.

" repens, Crantz.

Corallorrhiza maculata, Raf.

" odontorhiza, Nutt. Common in swamps.

“ trifida, Chatelain (Coral Root).

Microstylis monophyllos, Lindl.

Liparis loeselii, Richard.

Calypso bulbosa, Oakes. Found up the Don.

\section{Salicaceae (Willow Family).}

Salix alba, L. (White Willow). Introduced.

" babylonica, L. (Weeping Willow). Introduced.

" cordata, Muhl.

" discolor, Muhl.

" fragilis, L. (Crack Willow). Introduced.

" humilis, Mrarsh.

“ lucida, Muhl. (Shining Willow).

¿" nigra, Marsh. (Black Willow). 


\section{NATURAL HISTORY, TORONTO REGION}

Salix petiolaris, $\mathrm{Sm}$.

" purpurea, L. (Purple Willow). Introduced.

" sericea, Marsh.

Populus alba, L. (Silver-leaved Poplar). Introduced.

" balsamifera, L. (Balsam Poplar).

" candicans, Ait. (Balm of Gilead). Very rare.

“ deltoides, Marsh. (Cottonwood). Very rare.

“ grandidentata, Michx. (Large-toothed Aspen).

“ nigra, var. italica, Du Roi. (Lombardy P.)

Introduced.

“ tremuloides, Michx. (American Aspen).

\section{Mrricaceae (Sweet Gale Family).}

Myrica asplenifolia, L. (Sweet Fern). Common north of High Park.

\section{JUGLaNdaCeae (Walnut Family).}

Juglans cinerea, L. (Butternut).

" nigra, L. (Black Walnut). Infrequent. Almost its northern limit.

Carya cordiformis, K. Koch. (Bitternut Hickory). Fairly common.

. “ glabra, Spach. (Pignut). Very rare.

" ovata, K. Koch. (Shell-bark Hickory). Fairly common.

\section{Betulaceae (Birch Family).}

Corylus americana, Walt. (Hazelnut). Humber Valley. 


\section{THE SEED PLANTS OF TORONTO}

Corylus rostrata, Ait. The common species. Ostrya virginiana, K. Koch. (Ironwood). Common. Carpinus caroliniana, Walt. (Blue Beech). Betula alba, var. papyrifera, Spach. Common. “ lutea, Michx. (Gray Birch), Common. Alnus incana, Moench. (Alder). Abundant in low grounds.

\section{Fagaceae (Beech Family).}

Fagus grandifolia, Ehrb. (Beech). Very common. Quercus alba, L. (White Oak).

“ $\quad$ coccinea, Muench (Scarlet Oak).
" rubrocarpa, Michx. (Bur Oak).
"
$\quad$ velutina, Lam. (Black Oak).

\section{Urticaceae (Nettle Family).}

Ulmus americana, L. (White Elm). “ fulva, Michx. (Slippery Elm).

" racemosa, Thomas (Cork or Rock Elm).

Nearly exterminated.

Morus alba, L. (White Mulberry). An occasional escape.

Cannabis sativa, L. (Hemp). Humulus lupulus, L. (Common Hop). Escaped. Found in waste places.

Urtica gracilis, Ait. (Nettle). Laportea canadensis, Gaud. (Wood Nettle). Pilea pumila, Gray. (Clearweed). 


\section{NATURAL HISTORY, TORONTO REGION}

\section{Santalaceae (Sandalwood Family).}

Comandra umbellata, Nutt. (Bastard Toad-flax).

\section{Loranthaceae (Mistletoe Family).}

Arceuthobium pusillum, Peck (Dwarf Mistletoe). Abundant on Black Spruce at Wilcox L. and Snelgrove.

\section{Aristolochiaceae (Birthwort Family).}

Asarum canadense, L. (Wild Ginger). Common in rich woods.

\section{Polygonaceae. (Buckwheat Family).}

Rumex acetosella, L. (Sheep Sorrel).

“ britannica, L. (Great Water Dock).

" crispus, L. (Yellow Dock).

" pulcher, L.

" patientia, L.

" verticillatus, L. (Swamp Dock).

Polygonum acre, HBK. (Water Smartweed).

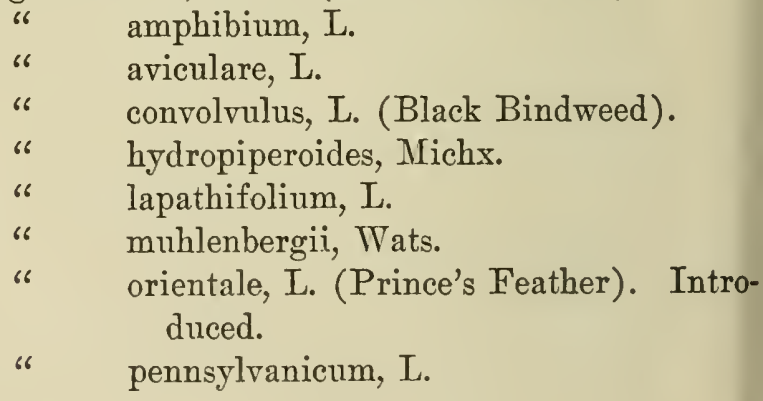




\section{THE SEED PLANTS OF TORONTO}

Polygonum persicaria, L. (Lady's Thumb).

Fagopyrum esculentum, Moench (Buckwheat). Persisting after cultivation.

\section{Chenopodiaceae (Goosefoot Family).}

- Chenopodium album, L. (Lamb's Quarters). “ botrys, L. (Jerusalem Oak).

“ glaucum, L. (Oak-leaved Geranium).

“ hybridum, L. (Maple-leaved G.)

" urbicum, L.

Atriplex patula, L.

Salsola kali, L. (Russian Thistle). Very rare.

\section{Amarantaceae (Amaranth Family).}

Amarantus blitoides, Wats.

" graecizans, L. (Tumble Weed).

" retroflexus, L. (Pigweed).

\section{Aizoaceae.}

Mollugo verticillata, L. (Carpet Weed).

\section{Caryophyllaceae (Pink Family).}

Stellaria longipes, Goldie.

" media, Cyrill. (Common Chickweed).

Cerastium viscosum, $\mathrm{L}$.

“ vulgatum, L. (Common Mouse-ear Chickweed).

Silene antirrhina, L. (Sleepy Catchfly).

" latifolia, B. \& R. A field pest. 


\section{NATURAL HISTORY, TORONTO REGION}

Silene noctiflora, L. (Night-flowering Catchfly). Saponaria officinalis, L. (Bouncing Bet). Escaped.

\section{Portulacaceae (Purslane Family).}

Portulaca oleracea, L. (Purslane).

Claytonia caroliniana, Michx. (Spring Beauty).

“ virginica, L. (Spring Beauty).

\section{Ceratophyllaceae (Hornwort Family).}

Ceratophyllum demersum, L. (Hornwort).

\section{Nymphaeaceae (Water Lily Family).}

Nymphaea advena, Ait. (Yellow Pond Lily).

Castalia odorata, Woodville and Wood (Water L.).

\section{Randnculaceae (Crowfoot Family).}

Ranunculus abortivus, L. (Small-flowered Crowfoot),

66

66

66

66

66

66

66

66 acris, L. (Buttercup).

aquatilis, var. capillaceus, DC. (Common White Water Crowfoot). fascicularis, Muhl. (Early Crowfoot). hispidus, Michx.

pennsylvanicus, L. (Bristly Crowfoot). recurvatus, Poir. repens, L. (Creeping Buttercup). rhomboideus, Goldie (Dwarf Buttercup).

sceleratus, L. (Cursed Crowfoot).

Thalictrum dioicum, L. (Early Meadow Rue). " 


\section{THE SEED PLANTS OF TORONTO}

Anemonella thalictroides, Spach. (Rue Anemone). Hepatica acutiloba, DC. (Hepatica). " triloba, Chaix. (Hepatica).

Anemone canadensis, L.

" cylindrica, Gray.

" quinquefolia, L. (Wood anemone).

" virginiana, Gray.

Clematis virginiana, $\mathrm{L}$.

Caltha palustris, L. (Marsh Marigold).

Coptis trifolia, Salisb. (Goldthread). Common at Mount Dennis.

Aquilegia canadensis, L. (Columbine). Actaea alba, Mill. (White Baneberry).

" rubra, Wild. (Red Baneberry).

\section{Magnoliaceae (Magnolia Family).}

Liriodendron tulipifera, L. (Tulip Tree). Planted. The Lake Erie district constitutes its northern limit.

\section{Menispermaceae (Moonseed Family).}

Menispermum canadense, L. (Moonseed). More common in Niagara area.

\section{Berberidaceae (Barberry Family).}

Podophyllum peltatum, L. (May Apple or Mandrake).

Jeffersonia diphylla, Pers. (Twinleaf). Caulophyllum thalictroides, Michx. (Blue Cohosh). 
NATURAL HISTORY, TORONTO REGION

\section{LAURACEAE (Laurel Family).}

Sassafras variifolium, Ktze. At its northern limit here.

Benzoin aestivale, Nees. (Wild Allspice). Especially in Niagara district.

\section{Papaveraceae (Poppy Family).}

Chelidonium majus, L. (Celandine). Sanguinaria canadense, I. (Bloodroot). Common up the Don.

Argemone mexicana, L. (Mexican Prickly Poppy).

\section{Fumariaceae (Fumitory Family).}

Adlumia fungosa, Greene (Climbing Fumitory). Dicentra canadensis, Walp. (Squirrel Corn).

" cucullaria, Bernh. (Dutchman's Breeches.)

\section{Cruciferae (Mustard Family).}

Thlaspi arvense, L. (Penny Cress).

Lepidium sativum, L. (Garden Cress). Introduced.

" virginicum, L. (Wild Peppergrass).

Coronopus procumbens, Gilibert. (Swine Cress). Capsella bursa-pastoris, Medic. (Shepherd's Purse). Camelina sativa, Crantz. (False Flax).

Cakile edentula, Hock. (American Sea Rocket). Brassica arvensis, Ktze. (Charlock).

Conringia orientalis, Dimort. 
Sisymbrium officinale, Scop.

“ sophia, L.

Erysimum cheiranthoides (Worm-seed Mustard).

" parviflorum, Nutt.

Radicula nasturtium-aquaticum, B. \& R.

“ palustris, Moench.

“ sylvestris, Druce.

Dentaria diphylla, Michx. (Toothwort).

Cardamine douglassii, Britton.

Arabis canadensis, L. (Sickle-pod).

\section{Resedaceae (Mignonette Family).}

Reseda alba, L. (Mignonette). Introduced.

\section{Sarraceniaceae (Pitcher-plant Family).}

Sarracenia purpurea, L. (Pitcher-plant).

Droseraceae (Sundew Family).

Drosera longifolia, L.

" rotundifolia, L. (Sundew).

\section{Crassulaceae (Orpine Family).}

Sedum acre, L. (Stone-crop). Introduced.

\section{Saxifragaceae (Saxifrage Family).}

Saxifraga virginiensis, Michx. (Early Saxifrage). Tiarella cordifolia, L. (False Miterwort).

Mitella diphylla, L. (Miterwort).

" nuda, $\mathrm{L}$. 


\section{NATURAL HISTORY, TORONTO REGION}

Chrysosplenium americanum, Schwein. (Golden Saxifrage).

Parnassia palustris, L. Grows in Humber Valley. Ribes cynosbati, L. (Prickly Gooseberry).

" floridum, I'Her. (Wild Black Currant).

\section{HaMaMeiddaceae (Witch-hazel Family).}

Hamamelis virginiana, L. (Witch Hazel). Common.

\section{Platanaceae (Plane Tree Family).}

Platanus occidentalis, L. (Buttonwood or Plane Tree). Near its northern limit here, but frequent in the interglacial deposits.

\section{Rosaceae (Rose Family).}

Spiraea salicifolia, L. (Meadow-Sweet).

Pyrus coronaria I. (American Crab). Humber plains.

Amelanchier canadensis, Medic. (Shad Bush).

"6 spicata, C. Koch.

Crataegus coccinea, L.

" crus-galli, L.

" oxyacantha, L. (English Hawthorn). Introduced, Sparingly escaped.

“ punctata, Jacq.

" tomentosa, $\mathrm{L}$.

Fragaria vesca, L. (Strawberry).

“ virginiana, Duchesne (Strawberry). 


\section{THE SEED PLANTS OF TORONTO}

Waldsteinia fragarioides, Trattinick (Barren Strawberry).

Potentilla anserina, L. (Silver Weed).

66
66
66
66
66
66 argentea, L. (Silvery Cinquefoil). canadensis, $\mathrm{L}$. intermedia, $\mathrm{L}$. monspeliensis, var. norvegica, Rybd. paradoxa, Nutt. recta, $\mathrm{L}$.

Geum canadense, Jacq.

" strictum, Ait.

Rubus allegheniensis, Porter (Blackberry).

" hispidus, $\mathrm{L}$.

" idaeus, var. aculeatissimus, Regel \& Tiling (Wild Red Raspberry).

" occidentalis, L. (Black Raspberry).

" odoratus, L. (Purple Flowering Raspberry).

" triflorus, Richards (Dwarf Raspberry).

"villosus, var. humifusus, T. \& G.(Dewberry).

Rosa blanda, Ait.

" carolina, L.

" humilis, Marsh.

" rubiginosa, L. (Sweetbrier).

Prunus americana, Marsh (Wild Plum). A northern record.

" pennsylvanica, L. (Bird Cherry).

" pumila, L. (Sand Cherry). Humber Valley near Lambton.

" serotina, Ehrh. (Black Cherry).

" virginiana, L. (Choke Cherry). 


\section{NATURAL HISTORY, TORONTO REGION}

\section{Leguminosae (Pulse Family).}

Gymnocladus dioica, Koch. (Kentucky Coffee-tree). Planted here, but found in Lake Erie district sparingly.

Lupinus perennis, L. (Wild Lupine). Trifolium agrarium, L. (Hop Clover).

66 arvense, L. (Rabbit-foot Clover).

“ hybridum, L. (Alsike Clover). Introduced.

“ pratense, L. (Red Clover).

" procumbens, L. (Low Hop Clover).

“ repens, L. (White Clover).

Melilotus alba, Desr. (White Melilot).

“ officinalis, Lam. (Yellow Melilot).

Medicago hispida, Gaertn. (Bur Clover). Introduced.

“ lupulina, L. (Black Medick).

“ sativa, L. (Alfalfa). Introduced.

Anthyllis vulneraria, L.

Robinia pseudo-acacia, L. (Common Locust). Escapes.

Desmodium canadense, DC.

" nudiflorum, D.C.

" paniculatum, DC.

Lespedeza capitata, Michx.

“ hirta, Hornem. Both species grow in High Park.

Vicia caroliniana, Walt. (Vetch).

" cracca, L. (Vetch). 
Lathyrus maritimus, Bigel. (Beach Pea).

“ palustris, $\mathrm{L}$.

Apios tuberosa, Moench. (Groundnut). Common in the Humber Valley.

Amphicarpa monoica, Ell. (Hog Peanut). Common.

\section{Linaceae (Flax Family).}

Linum striatum, Walt. Common on the Island.

" usitatissimum, L. (Flax). Introduced.

\section{Oxalidaceae (Wood Sorrel Family).}

Oxalis acetosella, L. (Common Wood Sorrel).

“ corniculata, L. (Lady's Sorrel).

" stricta, L.

\section{Geraitaceae (Geranium Family).}

Geranium carolinianum, L.

“ maculatum, L. (Wild Cranesbill).

" robertianum, L. (Herb Robert).

Erodium cicutarium, L'Her.

\section{Rutaceae (Rue Family).}

Ptelea trifoliata, L. (Hop Tree). In the Humber Valley. Its northern limit in the Niagara district.

Ailanthus glandulosa, Desf. (Tree of Heaven).

Planted.

\section{Polygalaceae (Milkwort Family).}

Polygala paucifolia, Willd. (Fringed Polygala). " polygama, Walt. 


\section{NATURAL HISTORY, TORONTO REGION}

Polygala senega, L.

" verticillata, $\mathrm{L}$.

\section{Euphorbiaceae (Spurge Family).}

Euphorbia helioscopia, L. (Sun Spurge).

" hirsuta, Wiegand.

“ lathyrus, $\mathrm{L}$.

“ maculata, $\mathrm{L}$.

“ platyphylla, L.

“ polygonifolia, $\mathrm{I}$.

Calitirichaceae (Water Starwort Family).

Callitriche palustris, $\mathrm{L}$.

\section{Avacardiaceae (Cashew Family).}

Rhus cotinus, L. (Smoke Tree). Planted.

" toxicodendron, L. (Poison Iry).

“ typhina, L. (Staghorn Sumach).

Celastraceae (Staff Tree Family).

Evonymus atropurpureus, Jacq. (Burning Bush). In the Humber Valley.

“ obovatus, Nutt. Plentiful up the Don. Celastrus scandens, L. (Bitter-sweet). Common.

Staphyleaceae (Bladder Nut Family).

Staphylea trifolia, L. (Bladder Nut). Northern. limit in the Niagara district. 


\section{THE SEED PLANTS OF TORONTO}

\section{Aceraceae (Maple Family).}

Acer negundo, L. (Manitoba Maple). Planted. " platanoides, L. (Norway Maple). Planted. “ pseudo-platanus, L. (Sycamore Maple). Planted.

" rubrum, L. (Red Maple).

" rubrum, var. tridens, Wood.

" saccharinum, L. (Silver Maple).

" saccharum, Marsh. (Sugar Maple).

" saccharum, var. nigrum, Britton. (Black Maple).

" spicatum, Lam. (Mountain Maple).

Sapindaceae (Soapberry Family).

Aesculus glabra, Willd. (Ohio Buckeye). Planted. " hippocastanum, L. (Horse Chestnut). Planted.

\section{Balsaminaceae (Touch-me-not Family).}

Impatiens biflora, Walt. (Spotted Touch-me-not). " pallida, Nutt. In Humber Valley.

\section{Rhamnaceae (Buckthorn Family).}

Rhamnus alnifolia, L'Her. (Buckthorn).

" cathartica, L. (Common Buckthorn).

Planted and escapes.

Ceanothus americanus, L. (New Jersey Tea).

\section{Vitaceae (Vine Family).}

Psedera quinquefolia, Greene (Virginia Creeper). Vitis vulpina, L. (Frost Grape.) 


\section{NATURAL HISTORY, TORONTO REGION}

\section{Tiliaceae (Linden Family).}

Tilia americana, L. (Basswood).

" europea, L. Planted.

\section{Malvaceae (Mallow Family).}

Malva rotundifolia, L.

" verticillata, $\mathrm{L}$.

Hibiscus trionum, L. (Flower-of-an-hour). Introduced. Common at York Mills.

\section{Hypericaceae (St. John's-wort Family).}

Hypericum ascyron, I. (Great St. John's Wort.) At Mount Dennis.

“ mutilum, L.

“ perforatum, L. (St. John's Wort).

\section{Cistaceae (Rockrose Family).}

Helianthemum canadense, Michx. (Frostweed). Lechea minor, L. Both species found on Humber plains.

\section{VIoLaceae (Violet Family).}

Viola blanda, Willd.

" canadensis, L. (Canada Violet).

" conspersa, Reichenb.

" cucullata, Ait.

" pubescens, Ait.

" renifolia, Gray.

" rostrata, Pursh. (Long-spurred Violet). 


\section{THE SEED PLANTS OF TORONTO}

Viola rotundifolia, Michx. (Early Yellow Violet).

" selkirkii, Pursh.

" sororia, Willd.

\section{Thymelaeaceae (Mezereum Family).}

Dirca palustris, L. (Leatherwood). Very rare here.

\section{Elaeagiaceae (Oleaster Family).}

Shepherdia canadensis, Nutt.

\section{Lythraceae (Loosestrife Family).}

Decodon verticillatus, Ell. (Swamp Loosestrife or Water Willow).

\section{Onagraceae (Evening Primrose Family).}

Ludvigia palustris, Ell. (Water Purslane).

Epilobium angustifolium, L. (Great Willow-herb or Fireweed).

“ coloratum, Muhl.

Oenothera biennis, L. (Evening Primrose).

Gaura biennis, L.

Circaea alpina, $\mathrm{L}$.

" lutetiana, L. (Enchanter's Night Shade).

\section{Haloragidaceae (Water Milfoil Family).}

Myriophyllum spicatum, L. (Water Milfoil). Proserpinaca palustris, L. (Mermaid Weed). Hippuris vulgaris, L. (Mare's Tail). All these genera grow in Ashbridge's Bay. 


\section{Aralitaceae (Ginseng Family).}

Aralia hispida, Vent. (Bristly Sarsaparilla).

" nudicaulis, L. Wild Sarsaparilla).

" racemosa, L. (Spikenard).

“ spinosa, L. (Hercules' Club). Planted.

Panax quinquefolium, L. (Ginseng).

" trifolium, L. (Dwarf Ginseng).

\section{Umbelliferae (Parsley Family).}

Sanicula marilandica, L.

Hydrocotyle americana, L.

Osmorhiza claytoni, Clarke.

" longistylis, DC.

Cicuta bulbifera, I.

" maculata, L. (Spotted Cowbane).

Carum carvi, L. (Caraway). Escaped.

Sium cicutaefolium, Schrank. (Water Parsnip).

Cryptotaenia canadensis, DC.

Taenidia integerrima, Drude.

Thaspium barbinode, Nutt. (Meadow Parsnip).

Heracleum lanatum Michx. (Cow Parsnip).

Daucus carota, L. (Wild Carrot).

\section{Cornaceae (Dogwood Family).}

Cornus alternifolia, L.

" amomum, L. (Silky Cornel or Kinnikinnik).

" canadensis, L. (Bunchberry).

“ circinata, L'Her. (Round-leaved Dogwood).

“ paniculata, L'Her.

“ stolonifera, Michx. (Red-osier Dogwood). 


\section{THE SEED PLANTS OF TORONTO}

\section{ERICACEAE (Heath Family).}

Chimaphila umbellata, Nutt. (Prince's Pine).

Moneses uniflora, Gray.

Pyrola americana, Sweet.

" elliptica, Nutt. (Skin Leaf).

" secunda, $L$.

Monotropa uniflora, L. (Indian Pipe).

Pterospora andromeda, Nutt. (Pine Drops).

Ledum groenlandicum, Oeder. (Labrador Tea).

Epigaea repens, L. (Mayflower or Trailing Arbu-

tus.) Is still to be found at High Park.

Gaultheria procumbens, L.

Chiogenes hispidula, T. \& G. Grows at Mount

Dennis.

Gaylussacia baccata, C. Koch. (Teaberry).

Vaccinium corymbosum, L. (Swamp Blueberry).

“ pennsylvanicum, Lam. (Low Sweet Blueberry).

“ vacillans, Kalm. (Late Low Blueberry).

These three species are common on the

Humber plains.

Primulaceae (Primrose Family).

Lysimachia nummularia, L. (Moneywort).

"

quadrifolia, L. (Loosestrife).

" terrestris, BSP.

“ thyrsiflora, L. (Tufted Loosestrife).

Steironema ciliatum, Raf.

Trientalis americana, Pursh. (Star Flower). Found in abundance west of the city. 


\section{NATURAL HISTORY, TORONTO REGION}

\section{Oleaceae (Olive Family).}

Fraxinus americana, L. (White Ash).

" excelsior, L. (European Ash). Planted.

" nigra, Marsh. (Black Ash).

" pennsylvanica, Marsh. (Red Ash). Not common.

Syringa vulgaris, L. (Lilac). Introduced. Ligustrum vulgare, L. (Privet). Introduced.

\section{Gentiataceae (Gentian Family).}

Gentiana andrewsii, Griseb. (Closed Gentian).

" crinita, Froel. (Fringed Gentian).

" quinquefolia, L.

" saponaria, L. (Soapwood Gentian).

Menyanthes trifoliata, L. (Water Buckbean).

\section{Apoctraceae (Dogbane Family).}

Vinca minor, L. (Common Periwinkle). A rare escape.

Apocynum androsaemifolium, L (Dogbane).

" cannabinum, L. (Indian Hemp). Both species grow on the Island.

\section{Asclepiadaceae (Milkweed Family).}

Asclepias incarnata, L. (Swamp milkweed).

" phytolaccoides, Pursh. (Poke milkweed).

" syriaca, L. (Common Milkweed).

“ tuberosa, L. (Pleurisy-root or Butterflyreed). 


\section{THE SEED PLANTS OF TORONTO}

Cynanchum nigrum, Pers. Introduced. Found in abundance in Don Valley.

\section{Convoluvelaceae (Convolvulus Family).}

Ipomoea purpurea, Roth. (Morning Glory). Convolvulus arvensis, L. (Field Bindweed). " sepium, L. (Hedge Bindweed). “ spithamaeus, L. Quite common in High Park.

Cuscuta gronovii, Willd. (Dodder).

\section{Polemoniaceae (Polemonium Family).}

Phlox divaricata, L. (Blue Phlox).

\section{Hydrophyllaceae (Waterleaf Family).}

Hydrophyllum canadense, L.

" virginianum, $\mathrm{L}$.

\section{Boraginaceae (Borage Family).}

Cynoglossum boreale, Fernald.

officinale, L. (Common Hound's
Tongue).

Lappula echinata, Gilibert.

“ redowskii, Greene, var. occidentalis, Rydb.

“ virginiana, Greene (Beggar's Lice).

Lycopsis arvensis, L. (Small Bugloss).

Myosotis arvensis, Hill (Forget-me-not).

" laxa, Lehm. (Forget-me-not).

Lithospermum arvense, L. (Corn Grommell). 


\section{NATURAL HISTORY, TORONTO REGION}

Lithospermum latifolium, Michx. Echium vulgare, L. (Blue-weed).

\section{Verbenaceae (Vervain Family).}

Verbena hastata, L. (Blue Vervain).

" urticaefolia, L. (White Vervain). Both species grow in the Don Valley.

\section{Labiatae (Mint Family).}

Teucrium canadense, L. (American Germander or Wood Sage.

Scutellaria galericulata, L. (Skulleap).

“ laterifolia, L. (Mad-dog Skullcap).

" parvula, Michx.

Agastache nepetoides, Ktze. (Giant Hyssop).

Nepeta cataria, L. (Catnip).

" hederacea, Trevisan. (Ground Ivy.)

Prunella vulgaris, L. (Heal-all).

Physostegia virginiana, Benth. Common on the Island.

Leonurus eardiaca, L. (Motherwort.)

Stachys palustris, L. (Plentiful on the Island.

Monarda didyma, L. (Oswego Tea).

" fistulosa, L. (Wild Bergamot).

Hyssopus officinalis, L. Introduced.

Origanum vulgare, L. (Wild Marjoram).

Pycnanthemum virginianum, Durand and Jackson.

Grows on the Island.

Lycopus americanus, Muhl.

“ virginicus, L. (Bugle Weed). 


\section{THE SEED PLANTS OF TORONTO}

Mentha arvensis, var. canadensis, Briquet.

“ piperita, L. (Peppermint). Grows on the Island.

" rotundifolia, Huds. Grows on the Island.

“ spicata, L. (Spearmint).

Collinsonia canadensis, L. (Rich-weed).

\section{Solanaceae (Nightshade Family).}

Solanum dulcamara, L. (Bittersweet).

" nigrum, L. (Common Nightshade).

" rostratum, Dunal. (Buffalo Bur.)

Physalis pruinosa, L. (Strawberry-Tornato).

Nicandra physalodes, Pers. (Apple of Peru).

Lycium halimifolium, Mill. (Common Matrimony

Vine).

Hyoscyamus niger, L. (Henbane).

Datura stramonium, L. (Thorn Apple).

\section{Scrophulariaceae (Figwort Family).}

Verbascum blattaria, L. (Moth Mullein).

" thaspus, L. (Common Mullein).

Linaria minor, Desf.

6

vulgaris, Hill. (Butter and Eggs). A form

of this species with white, spurless flowers grows at York Mills.

Scrophularia marilandica, L.

Pentstemon hirsutus, Willd. (Beard-tongue).

" laevigatus, Ait, Willd. (Beard-tongue).

Chelone glabra, L. (Turtlehead). At Mount Dennis. 


\section{NATURAL HISTORY, TORONTO REGION}

Mimulus moschatus, Dougl. (Musk Flower). Found in High Park.

“ ringens, L. (Monkey Flower).

Veronica anagallis-aquatica, L. (Water Speedwell).

" officinalis, L. (Common Speedwell).

“ serpyllifolia, L. (Common Speedwell).

Gerardia pedicularia, L. Humber plains.

“ purpurea, L. (Purple gerardia).

" virginica, BSP. (Smooth False Foxglove).

Castilleja coccinea, Spreng. (Painted Cup). Val-

ley of Humber.

Melampyrum lineare, Lam. (Cow Wheat).

Pedicularis canadensis, L. (Common Lousewort or

Wood Betony).

“ lanceolata, Michx. Grows near Grenadier Pond.

Levtibulartaceae (Bladderwort Family).

Utricularia vulgaris, var. americana, Gray (Greater Bladderwort).

Orobatchaceae (Broom-rape Family).

Epifagus virginiana, Bart. (Beech-drops).

Orobanche uniflora, L. (One-flowered Cancer-root).

\section{Bigmoniaceae (Bignonia Family).}

Tecoma radicans, Juss. (Trumpet Creeper). Cultivated.

Catalpa bignonioides, Walt. Planted.

" kaempferi. Planted. 


\section{THE SEED PLANTS OF TORONTO}

\section{Phrincaceae (Lopseed Family).}

Phryma leptostachya, L.

\section{Plattaginaceae (Plantain Family).}

Plantago lanceolata, L. (Rib Grass).

“ media, L. (Hoary Plantain).

“ major, L. (Common Plantain).

\section{RUdaceae (Madder Family).}

Galium aparine, L. (Cleavers).

“ asprellum, Michx. (Rough Bedstraw).

" boreale, I. (Northern Bedstraw).

" lanceolatum, Torr. (Wild Liquorice).

" trifidum, L.

" triflorum, Michx. (Sweet-scented Bedstraw).

“ verum, L. (Yellow Bedstraw).

Mitchella repens, L. (Partridge Berry).

\section{Caprifoliaceae (Honeysuckle Family).}

Diervilla lonicera, Mill. (Bush Honeysuckle).

Lonicera canadensis, Marsh (American Fly Honeysuckle).

" dioica, L.

" flava, Sims. (Yellow Honeysuckle).

“ tartarica, L. (Tartarian Honeysuckle). Escaped.

Symphoricarpos orbiculatus, Moench. (Indian Currant).

“

racemosus, Michx. (Snowberry). 


\section{NATURAL HISTORY, TORONTO REGION}

Linnaea borealis, var. americana, Rehder. (Twinflower).

Triosteum perfoliatum, L. (Tinker's Weed, or Wild

Coffee).

Viburnum acerifolium, L. (Arrow-wood).

“ dentatum, L. (Arrow-wood).

" lentago, L. (Sweet Viburnum).

" opulus, var. americanum, Ait. (High-bush cranberry).

" prunifolium, L. (Black Haw).

" pubescens, Pursh. (Downy Arrow-wood).

Sambucus canadensis, L. (Common Elder).

“ recemosa, L. (Red-berried Elder).

Dipsacaceae (Teasel Family).

Dipsacus sylvestris, Huds. (Teasel).

Cucurbitaceae (Gourd Family).

Sicyos angulatus, L. (One-seeded Bur Cucumber). Common in waste places about the city.

Echinocystis lobata T. \& G.

\section{Campanulaceae (Bluebell Family).}

Campanula aparinoides, Pursh. (Marsh Bellflower). " rotundifolia, L. (Harebell).

\section{Lobeliaceae (Lobelia Family).}

Lobelia inflata, L. (Indian Tobacco).

" kalmii, L. A white form, as well as the blue, occurs on the Island. 


\section{THE SEED PLANTS OF TORONTO}

Lobelia siphilitica, L. (Great Lobelia).

“ spicata, Lam.

\section{Compositae (Composite Family).}

Eupatorium perfoliatum, L. (Boneset).

"6

66

purpureum, L. (Joe-Pye Weed).

urticaefolium, Richard. (White Snake-

$$
\text { root). }
$$

Liatris cylindracea, Michx.

Grindelia squarrosa, Dunal. (Gum-plant). Introduced from the North-West.

Solidago caesia, L.

" canadensis, $\mathrm{I}$.

“ graminifolia, Salisb.

" hispida, Muhl.

“ juncea, Ait.

" latifolia, L.

" nemoralis, Ait.

“ patula, Muhl.

“ serotina, Ait.

“ squarrosa, Muhl.

" uliginosa, Nutt.

Aster azureus, Lindl.

" cordifolius, L.

" divaricatus, L.

" dumosus, L.

" ericoides, L.

" junceus, Ait.

" laevis, L.

" lateriflorus, Britton. 


\section{NATURAL HISTORY, TORONTO REGION}

Aster lindleyanus, T. \& G.

" macrophyllus, $\mathrm{L}$.

" norae-angliae, $\mathrm{L}$.

“ paniculatus, Lam.

" puniceus, L.

" tradescanti, $\mathrm{L}$.

" umbellatus, Mill.

Erigeron acris, var. asteroides, DC.

“ annuus, Pers.

“ philadelphicus, L.

“ pulchellus, Michx.

“ ramosus, BSP.

Antennaria plantaginifolia, Richards. (Plantainleaved Ererlasting).

Anaphalis margaritaceae, B. \& H. (Pearly Everlast-

$$
\text { ing). }
$$

Gnaphalium decurrens, Ires. (Everlasting).

" polycephalum, Michx. (Common Ever-

$$
\text { lasting). }
$$

Inula helenium, L. (Elecampane). Ambrosia artemisiifolia, L. (Ragweed).

" trifida, I. (Great Ragweed).

Xanthium echinatum, Murr. (Cocklebur).

Rudbeckia hirta, L. (Black-eyed Susan).

" laciniata, $\mathrm{L}$.

Helianthus annuus, L. (Common Sunflower).

"6 decapetalus, $\mathrm{L}$.

"divaricatus, $\mathrm{L}$.

" strumosus, L. 


\section{THE SEED PLANTS OF TORONTO}

Helianthus tuberosus, L. (Jerusalem Artichoke).

Escaped.

Bidens cernua, L. (Stick-tight).

" connata, Muhl. (Swamp Beggar-ticks).

“ frondosa, L. (Beggar-ticks).

Galinsoga parviflora, Cav. Grows on Ontario Street. Achillea millefolium, L. (Yarrow). Anthemis cotula, L. (May-weed).

Chrysanthemum leucanthemum, L. (Ox-eye Daisy).

Tanacetum vulgare, L. (Tansy).

Artemisia absinthium, L. (Wormwood).

"6 annua, $\mathrm{L}$.

“ canadensis, Michx.

" caudata, Michx.

" ludoviciana, Nutt.

" vulgaris, L. (Mugwort).

Tussilago farfara, (Coltsfoot). Common on Scarborough Cliffs.

Petasites palmatus, Gray.

Erechtites hieracifolia, Raf. (Fireweed).

Senecio balsamitae, Muhl.

" $\quad$ vulgaris, L. (Groundsel).

Arctium lappa, L. (Burdock).

Cirsium altissimum, Spreng.

" arvense, Scop. (Canada Thistle).

" lanceolatum, Hill. (Bull Thistle).

" muticum, Michx. (Swamp Thistle).

Centaurea cyanus, L. (Bachelor's Button). Introduced.

\$6 solstitialis, L. (Barnaby's Thistle). 


\section{NATURAL HISTORY, TORONTO REGION}

Cichorium intybus, L. (Chicory).

Leontodon autumnalis, L. (Fall Dandelion).

Tragopogon porrifolius, L. (Oyster Plant). Escaped.

$$
\text { “ pratensis, L. (Goat's Beard). }
$$

Taraxacum officinale, Weber. (Dandelion).

Sonchus arvensis, L. (Field Sow Thistle).

“ asper, Hill (Spiny-leaved Sow Thistle).

" oleraceus, L. (Common Sow Thistle).

Lactuca canadensis, L. (Wild Lettuce).

“ scariola, L. (Prickly Lettuce).

Prenanthes alba, L. (Rattlesnake-root).

“ altissima, $\mathrm{L}$.

Hieracium canadense, Michx. (Hawkweed).

" florentinum, All. (King Devil). Grows in Don Valley.

" scabrum, Michx.

\section{REFERENCES.}

Gray's New Manual of Botany (Robinson \& Fernald). 7th. Ed.

Britton and Brown-An Illustrated Flora of the Northern United States and Canada.

Scott, Wm.-Flora of Ontario (A Check-List of the

Plants in the Herbarium of the Education Department). 


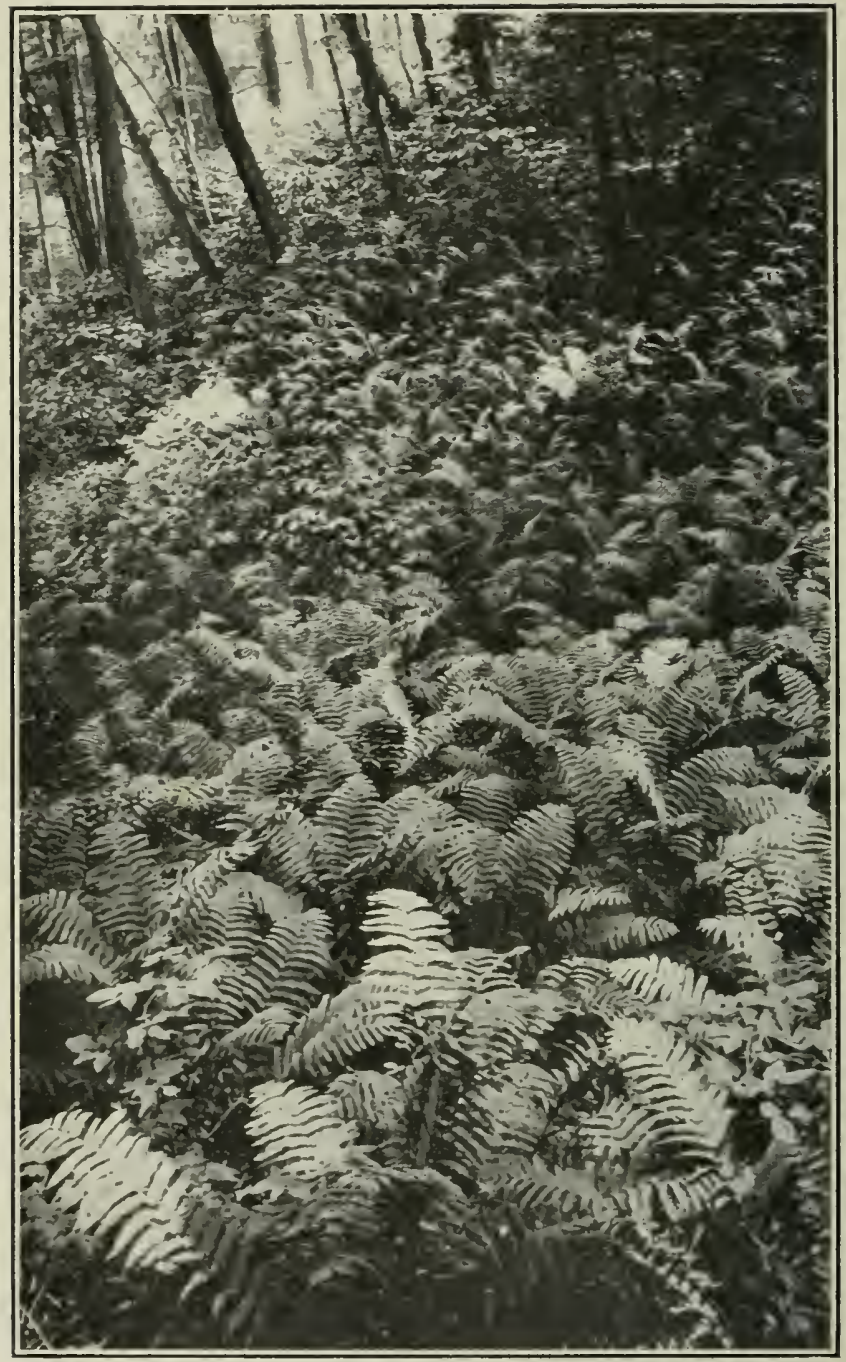

FERN COLONY, OSMUNDA CLAYTONIANA. 


\section{CHAPTER VII.}

\section{FERNS AND FERN ALLIES.}

By

T. J. IVEY, M.A.,

Science Master. Harbord Collegiate Institute.

Owing to the sandy or heavy nature of the soil in and about Toronto, and the comparatively dry atmosphere, the representatives of this group of plants are not numerous, and the individual species, on the whole, are rather medium-sized. In certain localities throughout the province, however, where conditions of soil and moisture are suitable, magnificent specimens are often found. In the northern part of the province specimens of the Bracken fern, for example, have been found to attain a height of six or seven feet, and in one locality in the eastern part of the province the Boulder fern, where protected by a shaded limestone cliff, has been observed to produce fronds five feet in length; the average size for both these being perhaps about two to three feet. There are many localities, too, throughout the province where typical rock-loving ferns are numerous, such as at Niagara and Credit Forks, where the rocks are chiefly calcareous. Here occur such species as Purple Pellaea, Narrow-leared Spleenwort, Maiden- 


\section{NATURAL HISTORY, TORONTO REGION}

hair Spleenwort, and Goldie's fern. There are also certain northérn forms characteristic of the igneous rocks of the northern part of the Province. Amongst these we have the New York fern, Woodsias, Fragrant Shield fern, and several Lycopodiums. Certain forms, again, which are quite common in other countries are quite local and rare in this, as is the case with the male fern, Hart's Tongue, and Wall Rue.

The following list includes the more commonly occurring Pteridophyta, as well as a few that are quite local and rare.

\section{Polypodiaceae.}

1 Adiantum pedatum, I. (Maidenhair). Fairly common in secluded parts of rich woods.

2. Polypodium vulgare, L. (Common Polypody). Common in the crevices of limestone rocks and at the foot of granite cliffs at Niagara Glen, Credit Forks, and throughout the province generally.

3. Phegopteris polypodioides, Fée (Long Beechfern). Rather rare on shaded bank at Highland Creek, but quite common in the northern part of the province, where Phegopteris hexagonoptera (Broad Beech-fern) is reported to occur with it occasionally (Shaw); also rare in rich woods at Inglewood, Ont. (IVhite).

4. Phegopteris dryopteris, Fée (Oak Fern). Universally common in rich roods. 


\section{FERNS AND FERN ALLIES}

5. Pteris aquilina, L. (Brake or Bracken). Common everywhere, mostly in open, sandy ground.

6. Pellaea atropurpurea, Link. (Purple-stemmed Cliff-brake). Occurs extensively at Niagara Glen and at Credit Forks and in many other Iocalities, usually high up in crevices of limestone cliffs.

7. Cryptogramma stelleri, Prantl. (Slender Cliffbrake). Reported rare at Credit Forks on the face of limestone cliffs (White).

8. Woodwardia virginica, Sm. (Virginia Chainfern.) Apparently very local. There is a large colony of it near Snelgrove, in Peel County (White). Farther north it occurs more commonly in sphagnum bogs and marshes near Port Sydney, Muskoka, and other localities.

9. Asplenium viride, Huds. (Green Spleenwort). Reported rare in crevices of limestone rocks at Credit. Forks (White).

10. Asplenium trichomanes, L. (Maidenhair Spleenwort). Common on moss-covered logs and limestone rocks at Niagara Glen and Credit Forks.

11. Asplenium angustifolium, Michx. (Narrowleaved Spleenwort). Very local. Occurs with Aspidium goldeanum and Asplenium acrostichoides at Niagara Glen and at Madoc in eastern Ontario, in rich, damp woods. Reported also rare in low woods at Credit Forks (White), and from the Don Valley, Toronto.

12. Asplenium acrostichoides, Sw. (Silvery Spleenwort). Although common in northern Ontario, near 


\section{NATURAL HISTORY, TORONTO REGION}

Toronto it appears to be quite rare. In southwestern and eastern Ontario it is also fairly common.

13. Asplenium filix-femina, Bernh. (Lady Fern). Very common and varied in form according to habitat and locality. Occurs in moist woods.

14. Camptosorus rhizophyllus, Link. (Walking Fern). On moist moss-covered limestone rocks at Niagara Glen. In similar habitat at Credit Forks (White). Also from several other localities in Ontario.

15. Polystichum acrostichoides, Schott. (Christmas Fern). Common generally in rich rocky woods.

16. Aspidium thelypteris, Sw. (Marsh Shield Fern). Common everywhere from south to north along the grassy borders of marshes.

17. Aspidium noveboracense, Sw. (New York Fern). Reported rare in low woods from Peel County (White). Common northward.

18. Aspidium marginale, Sw. (Evergreen Woodfern). One of the most common ferns, occurring in open rocky woods.

19. Aspidium goldianum, Hook. (Goldie's Fern). Occurs in the Niagara peninsula, at Niagara Glenn and in eastern Ontraio, in low rich woods in calcareous soil.

20. Aspidium boottii, Tuckerm. (Boott's Shieldfern). Several plants found at Madoc, Onto, at the foot of a limestone cliff in shaded situation. Here it occurred with Aspidium spinulosum intermedium and Aspidium marginale. 


\section{FERNS AND FERN ALLIES}

21. Aspidium cristatum, Sw. (Crested Shieldfern). Quite a common fern along the borders of swamps and marshes, in grass.

22. Aspidium cristatum, var. clintonianum, D. C. Eaton. Found quite commonly in several localities. At York Mills, Niagara Glen, in northern and eastern Ontario in more shaded habitat than the species.

\23. Aspidium spinulosum, var. intermedium, D. C. Eaton. This is perhaps our most common fern, occurring in rich woods everywhere.

24. Cystopteris bulbifera, Bernh. (Bladder Fern). One of the most common swamp ferns. It is very common in southern Ontario, but is rare locally northward.

25. Cystopteris fragilis, Bernh. (Brittle Fern). Widely distributed throughout Ontario, and varied in form and habitat; occurring in some places on exposed rocks, but mostly in shade.

26. Woodsia ilvensis, R. Br. (Rusty Woodsia). This is a typical northern fern, occurring on secluded rocks.

27. Dicksonia punctilobula, Gray (Hay-scented Fern). This is also a common northern species, growing around rocks in the open. Occurs also in shaded situations near Madoc. Reported from Inglewood in rocky woods (White).

28. Onoclea sensibilis, L. (Sensitive Fern), with he var. obtusilobata is very common in low, grassy ields and thickets throughout Ontario. 


\section{NATURAL HISTORY, TORONTO REGION}

29. Onoclea struthiopteris, Hoffm. (Ostrich Fern). This is one of our best known ferns, growing mostly in moist, open situations. Under favourable conditions it reaches a height of four or five feet.

\section{Osmundaceae.}

1. Osmunda regalis, L. (Royal Fern or Flowering Fern). Common northward along the borders of streams and ponds, also throughout Ontario locally.

2. Osmunda claytoniana, L. (Interrupted Fern). Near Toronto, in Ashbridge's "Wood," High Park, and along the Humber River. Distributed throughout Ontario.

3. Osmunda cinnamomea, L. (Cinnamon Fern). This species is often found in the same localities as the preceding, but usually in more moist and shaded localities.

\section{Ophioglossaceae.}

1. Ophioglossum vulgatum, L. (Adder's-tongue). Very rare near High Park, Toronto. Near Port Sydney, Muskoka, Ont., it occurs in long grass in damp ground, in shaded situation.

2. Botrychium lunaria, Sw. (Moonwort). This has been reported from Northern Ontario.

3. Botrychium simplex, Hitchcock (Little Grapefern). Found in one locality in open woods near High Park, Toronto. Also reported frequent on upland pastures in Peel County (White). 


\section{FERNS AND FERN ALLIES}

4. Botrychium lanceolatum, var. angustisegmentum, Pease and Moore (Lance-leaved Grape-fern). Found in one locality near Port Sydney, Muskoka, Ont. Also reported from Peel Co. (White).

5. Botrychium ramosum, Aschers. Occurs with Botrychium lanceolatum var. in rich woods.

6. Botrychium obliquum, Muhl. Common northward in open grassy fields. Also from Peel Co. (White).

7. Botrychium ternatum, var. intermedium, D. C. Eaton. Large specimens of this plant occur rarely in High Park, Toronto, in open sandy soil.

8. Botrychium virginianum, Sw. (Rattlesnake Fern). This is the most common of the Botrychiums in rich woods throughout Ontario.

\section{Equishtaceae.}

1. Equisetum arvense, L. (Field Horsetail). Common in wet sandy soil everywhere.

2. Equisetum sylvaticum, L. (Wood Horsetail). Common in damp woods, in light soil near Toronto; llso in many other localities throughout the province.

3. Equisetum hyemale, L. (Scouring-rush). Ocurs around Toronto on damp hillsides and ravines.

4. Equisetum fluviatile, L. (Pipes or Swamp Horsetail). Very common in muddy secluded itches, amongst grass or in shallow water. Found long the Humber River, Toronto. 
5. Equisetum variegatum, var. jesupi (?). This oceurs locally, but is quite common in certain localities-at Toronto Island, along Humber River, Toronto, and at one locality in Eastern Ontario near Madoc. Found in damp sand.

6. Equisetum scirpoides, Michx. Appears to be the second most common Equisetum around Toronto. It is to be found growing on moist mounds in low woods.

\section{LyCOPODIACEAE.}

1. Lycopodium selago, L. This species, as far as reported, has been found only in Northern Ontario in low rocky woods.

2. Lycopodium lucidulum, Michx. (Shining Clubmoss). Frequent in High Park, Toronto, but rapidly disappearing.

3. Lycopodium inundatum, L. (Bog Club-moss). Found mostly northward along the boggy shores of lakes and ponds.

4. Lycopodium annotinum, L. (Stiff Club-moss). Reported common in woods, Peel Co. (White); also common northward.

5. Lycopodium obscurum, var. dendroideum, D.C. Eaton (Ground Pine). Found occasionally in rich woods. Common northward.

6. Lycopodium complanatum, L. (Ground Pine or Trailing Christmas-green). One plant found at Credit Forks, Ont. (White). Common northward. 


\section{FERNS AND FERN ALLIES}

7. Lycopodium tristachyum, Pursh. A large bed in dry shallow soil found near Port Sydney, Muskoka, Ont.

8. Lycopodium clavatum, L. (Common Club-moss), also the variety monostachyon, Grev. and Hook, occurs in several localities northward. Species reported rare in one locality, Peel Co. (White).

\section{Selaginellaceal.}

1. Selaginella rupestris, Spring. Common in several localities throughout Ontario on dry rocks.

2. Selaginella apus, Spring. This species also occurs locally throughout Ontario, in damp grass, often along the borders of lakes.

\section{ISOETACEAE.}

1. Isoetes echinospora var. braunii, Engelm. (Braun's Quillwort). Found in one locality in sandy bottom of lake and river near Port Sydney, Muskoka, and very locally elsewhere in the Archaean district.

\section{REFERENCES.}

Gray's New Manual of Botany (Robinson \& Fernald), 7th ed.

Britton and Brown. An Illustrated Flora.

Clute. Our Ferns in their Haunts. 


\title{
GHAPTER VIII.
}

\section{MOSSES AND LIVERWORTS.}

B 8

\author{
G. H. GRAHAM, M.A.
}

The Geological Survey of Canada has published comprehensive lists of the Bryophyta-Part VI on the Mosses, VII including the Liverworts-and these contain a good representation of Southern Ontario forms, and especially of the Lake Erie and Eastern Lake Ontario Districts. As Toronto lies between the two it probably comprises in its flora a majority of the species found in both. If this be the case the following list contains little more than a third of the mosses and liverworts growing within easy collecting distance of the city.

The author is under special obligation to Professor Coleman for the list of interglacial mosses from Scarborough and the Don.

\section{Hepaticae-Liverworts.}

\section{Family Ricciaceae.}

Riccia fluitans, L. In ponds. Near High Park and in Rosedale Ravine, Toronto. 


\section{MOSSES AND LIVERWORTS}

Riccia natans, L. Abundant at Guelph and at Niagara Falls in stagnant pools.

\section{Family Marchantiaceae.}

Conocephalus conicus (L.), Dum. Abundant everywhere in woods.

Lunularia vulgaris. In greenhouses locally. Marchantia polymorpha, L. Rather common. Preissia quadrata (Scop.), Nees. (Preissia commutata, Nees). Found repeatedly at York Mills.

Family Metzgeriaceae. Aneura multifida, Dum. Rich woods. Common.

\section{Family Jungermanniaceae.}

Bazzania trilobata (L.), S. F. Gray. Ravines west of High Park.

Geocalyx graveolens (Schrad.), Nees. Ravines west of High Park.

Lophocolea heterophylla (Schrad.), Dum. Ravines west of High Park.

Porella platyphylla (L.), Lindb. Woods at Wilcox Lake, near Toronto.

Ptilidium ciliare (L.), Nees. Radula complanata (L.), Dum.

Family Anthocerotaceae.

Anthoceros sp. Common in lowlands in High Park and East Toronto. 


\section{NATURAL HISTORY, TORONTO REGION}

\section{Musci-Mosses.}

Family Sphagnaceae.

Sphagnum acutifolium, Ehrh. Common. cymbifolium, Ehrh. Common. “ squarrosum, Pers. Common.

There are sphagnum bogs at Wilcox Lake, Highland Creek, Snelgrove, and other places almost as accessible, and remains of a sphagnum vegetation just west of High Park. Up to about 1905 there was one at Swansea, and in it there was a typical and abundant bog flora, including pitcher plants, sundews, etc.

\section{Family Georgiaceae}

Georgia pellucida (L.), Rabenh. Everywhere common.

Family Polytrichaceae.

Catharinea undulata (L.), W. \& M. Abundant in woods.

Polytrichum commune, L.

" juniperinum, Willd.

\section{Family Dicranaceae.}

Ceratodon purpureus (L.), Brid. Common.

Dicranum flagellare, Hedw. In woods at Bond Lake, near Toronto.

Leucobryum glaucum (L.), Schimp. Woods in Long Branch Park, Toronto.

Dicranella varia, Schimp. Wet clay banks, Bloor Street West. 

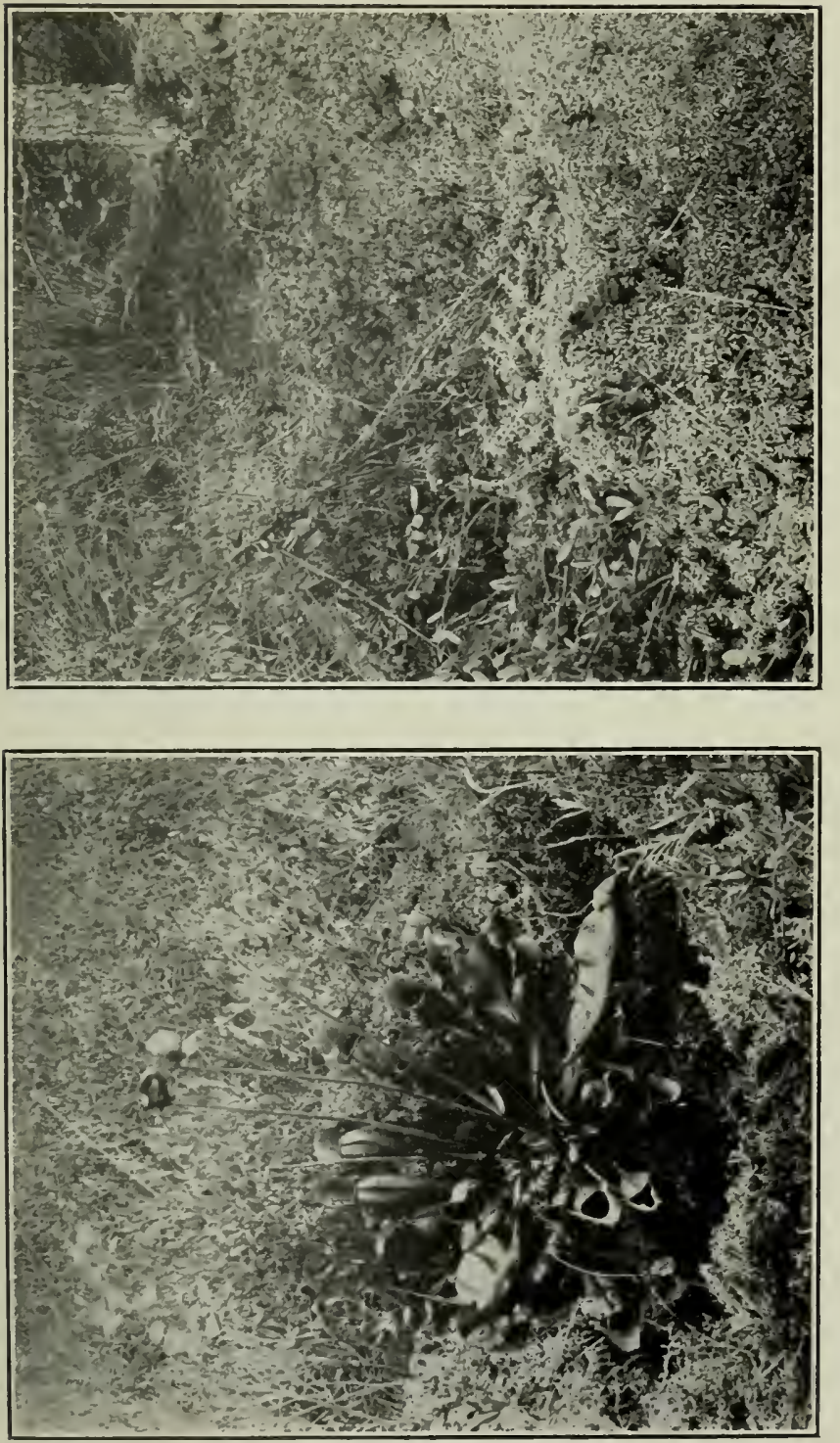

15

$\dot{\Xi}$
$\dot{\Xi}$
$\dot{0}$ 

Family Grimmiaceae.

Grimmia apocarpa (L.), Hedw., var. gracilis (Schleich.), W. \& M. Growing on stones in woods along the Humber River.

Hedwigia ciliata, Ehrh.

\section{Family Tortulaceae.}

Barbula unguiculata (Huds.), Hedw. Banks of the Humber River.

Weisia viridula, Brid. Dry clay banks in woods northeast of Taylor's brickyards.

\section{Family Funariaceae}

Physcomitrium turbinatum (Michx.), Brid. Wet, shady woods at York Mills.

Funaria hygrometrica (L.), Sibth. Common on waste ground.

\section{Family Timmiaceae.}

Timmia megapolitana, Hedw. Swamps at Jefferson, near Toronto.

Family Aulacomniaceae.

Aulacomnium heterostichum (Hedw.), B. \& S. " palustre, Schwaegr. Common in wet places.

Family Bartramiaceae.

Bartramia pomiformis (L), Hedw. Not uncommon. 153 
Family Bryaceae.

Pohlia nutans (Schreb.), Lindb. High Park. Rhodobryum roseum (Weis.), Limpr. Humber Valley.

Bryum caespiticium, L.

" intermedium, Brid.

" pendulum (Hornsch.), Schimp.

Mnium cuspidatum (L.), Leyss.

" medium, B. \& S.

\section{Family Leskeaceae.}

Thuidium delicatulum (L.), Mitt. Rather common. Pterigynandrum filiforme (Timm.), Hedw., var. minus L. \& J. On stones in woods, Humber River.

Family Hypnaceae.

Hylocomium proliferum (L.), Lindb. Woods at

Wilcox Lake.

" triquetrum (L.), B. \& S. Common.

" umbratum (Ehrh.); B. \& S. Swamp

at Mount Dennis.

Brachythecium acutum (Mitt.), Sulliv. Woods at York Mills.

“ salebrosum (Hoffm.), Br. \& Sch. Dry rotten stumps in woods, High Park.

Climacium americanum, Brid.

" dendroides (L.), Web. \& Mohr. Bond Lake. 


\section{MOSSES AND LIVERWORTS}

Calliergon schreberi (Willd.), Kindb. Wilcox Lake. Variable in habit of growth.

Campylium chrysophyllum (Brid.) Bryhn. Banks of Humber River.

“ hispidulum (Brod.), Mitt. Bond Lake. " stellatum (Schreb.), Bryhn. High Park.

Hypnum crista-castrensis, L.

" filicinum, L.

" imponens, Hedw. Woods at Jefferson.

" patientiae, Lindb. Bond Lake.

“ starkii, Brid.

Plagiothecium denticulatum (L.), B. \& S. Bond Lake.

66 pulchellum (Dicks.), B. \& S., var. nitidulum (Wahl.), Husn. High Park.

Mosses from the Interglacial Beds of Toronto.

(Scarborough and Don Valley.)

1. Hylocomium spec.

2. Drepanocladus capillifolius, Warnst.

3. " $"$ vernicosus (Lindb.).

4. " " lycopodioides (Brid.).

5. " " aduncus (Hedw.).

6. " " fluitans (?) (Del.).

7. Hygrohypnum palustre (?) (Huds.).

8. " montanum (?) (Wils.).

1-3 and 7 det. by A. J. Grout, Ph.D.

4-8 det. by Mrs. E. G. Britton. 


\section{NATURAL HISTORY, TORONTO REGION}

The following notes refer to the occurrence of these species in the present-day flora.

Drepanocladus capillifolius has been collected near Montreal, but is probably rare in Eastern America. It is frequent on the Pacific coast.

Drepanocladus vernicosus is a rather rare species of swamps and bogs to the south, but is said to be common in similar habitats in Canada north of Lake Superior and to the west. It has also been found in Prince Edward Island and Anticosti.

Drepanocladus lycopodioides is certainly rare in our range. It grows in bogs and peat meadows and is found as far north as Greenland.

Drepanocladus aduncus occurs on wet earth, stones, pools, spring places, swamps, and is reported throughout Canada, including the Lake Ontario district.

Drepanocladus fluitans is a moss of swamps, pools and peat bogs. Its range extends from Labrador to British Columbia.

Hygrohypnum palustre is uncommon to the south, but is said to be frequent in Canada on rocks in rivers. It is reported from New Brunswick, Gaspé, Owen Sound, Lake Superior, and British Columbia.

Hygrohypnum montanum is regarded as an alpine or subalpine moss of New England, Canada and Newfoundland. It is common to several stations in Canada, and among others to Owen Sound. It grows in mats on wet or submerged rocks. 


\section{MOSSES AND LIVERWORTS}

\section{REFERENCES.}

Barnes and Heald-Keys to the Genera and Species of North American mosses (Univ. of Wiscon$\sin$ ).

Grout-Mosses with a Hand-Lens.

Grout-Mosses with Hand-Lens and Microscope (New York). 


\section{CHAPTER IX.}

\section{MUSHROOMS AND OTHER FUNGI.}

By

THOMAS LANGTON, M.A., LL.B.

For probably ifty years persons who have received scientific training have been studying the fungi of particular districts in the United States, and have from time to time published the results of their researches; but no persons so qualified have made much investigation into the fungi of Canada or even of Ontario, or, if investigations have been made, the results have not been published so as to be generally accessible. The Geological Survey, which has for many years been compiling a Catalogue of Canadian Plants, has not yet reached the fungi, and so far as I have been able to learn has made very little preparation for making a list of them. There have not been wanting, however, amateurs who have as a recreation collected the larger or more conspicuous fungi which they have met with, and have either endeavoured themselves to identify them or have sent them to experts in the United States for identification, and have experimented in them as delicacies for the table.

Of recent years there has been a considerable popular inclination towards the study of at least the 


\section{MUSHROOMS AND OTHER FUNGI}

edible fungi. Not many years ago there was scarcely any literature on the subject which was easily arailable, or was of much use, on this side of the Atlantic, but within the last ten or twelve years several popular handbooks have been published in the United States which are more or less useful in Canada; and there must be spread over the country quite a number of persons who are examining, and sometimes adding to the supplies of the domestic table, the edible fleshy fungi of their neighbourhood, without venturing to put forth to the public any account of them. It is to be hoped that before long some of these workers will publish in some way at least descriptions or lists of what they have found, so that others may be helped and a foundation may be laid for a general list of the fungi of Canada.

There are undoubtedly several of such persons within the district with which we are at present concerned, viz., the district within a radius of fifty miles from Toronto. A district so defined would include almost the whole of the counties of York, Peel, Halton, Wentworth, Lincoln, and Dufferin, as well as large parts of Welland, Wellington, Simcoe, Ontario and Durham. In these counties the neighbourhoods of Fergus, Elora, Guelph, Preston, Hamilton, Orangeville, Georgetown, Oshawa, Niagara Falls and the Niagara River Gorge, Caledon Mountain, and the shores of Lake Simcoe and Lake Scugog, have long been fruitful botanizing fields, and should be able to return a good account of the fungi. 


\section{NATURAL HISTORY, TORONTO REGION}

The only fungus student of Toronto that I am aware of who has made public anything of his researches is also one of the earliest. In 1871, Daniel Knode Winder published a pamphlet of twenty-four pages "to enable the reader to identify our best species of mushrooms." This little book contained descriptions, with figures, of seven of the principal edible species and a catalogue of 108 species collected by the author, of which he specified thirty-seven which he had himself eaten. He does not say in what district his collections were made. If the thirty-seren specially mentioned were found near Toronto, there are ten of them which I have not met with, viz. (adopting the author's nomenclature), Agaricus gambosus, Agaricus odorus, Agaricus rachodes, Agaricus prunulus, Agaricus villaticus, Agaricus excoriatus, Agaricus orcella, Hygrophorus pratensis, Hygrophorus niveus, and Hygrophorus virgineus; and of the others in his list there are forty which I have either not met with or not identified.

Any collecting that I have done has been largely confined to places within easy reach of Toronto, including, however, some places outside of the fiftymile radius from Toronto, such as the Muskoka Lakes and the shores of some parts of the Georgian Bay. In all, I have found probably about four hundred species, but of these I hare not been able to feel sure of the identification of more than 150. I have kept descriptions, and in most cases drawings or 


\section{MUSHROOMS AND OTHER FUNGI}

photographs of nearly three hundred specimens which I have not been able to identify with confidence. Besides these, there are many which I have not attempted to do anything with, and no doubt there are many which I have not fallen in with or have not noticed. It would seem, therefore, that there is an abundant field for study in this district.

\section{Edible Fungi near Toronto.}

In regard to the edibility of the species which $I$ have collected, I have not experimented much; but I have tried twenty-nine species, twenty of which have met with sufficient approval to be always gathered for the table, when found conveniently and in sufficient quantities at a time.

While there are to be found near Toronto many edible species, comparatively few species occur in sufficient numbers at a time to make them worth while gathering. Edible Russulae, for instance, in most places come up scarcely a dish at a time in any one place. The same may be said of the Boleti. There are, of course, exceptional places, such as De Grassi Point on Lake Simcoe, where, in the extensive groves of oaks, Russulae are extraordinarily plentiful in July and August. On the other hand, in about September any one who finds the Honey-coloured Mushroom (Armillaria mellea) and the Brick-top (Hypholoma sublateritium) good eating will have no difficulty in obtaining an ample supply. Large quantities also of the Fairy Ring Mushroom (Maras- 
mius oreades) may in their season be easily gathered. It is, indeed, surprising that this last species is not better known and more used. It is excellent and can be readily dried so as to be kept for winter use. A wide-awake mycophagist may also in our streets and parks find casual dishes of Coprinus micaceus, Hypholoma incertum, or Hypholoma appendiculatum, Collybia velutipes and some puffballs by seizing the right moment, before the lawn mower or the destroying foot of the small boy or the too rapid natural process of decay has removed them. So also considerable patches of the Inky Coprinus (Coprinus atramentarius) when once discovered may furnish a succession of crops.

Besides the above, however, not many species offer any very reliable supplies. It may almost be said that they are only made use of by those who are interested in them as a subject of study. By the curious, in good woods in summer, almost daily supplies may, in places frequented by summer holidaymakers, be obtained of certain woods-loving species, e.g., Clitocybe infundibuliformis, Collybia radicata, Collybia platyphylla, Pleurotus ostreatus and sapidus, Cantharellus cibarius and several Hydnums, Russulas and Boleti; but there would not seem to be any considerable use made anywhere in this country of wild-growing fungi. We may except perhaps the morels and large puffballs, such as Calvatia gigantea, and, of course, the common Field Mushroom (Agaricus campester); many country dwellers do know and 


\section{MUSHROOMS AND OTHER FUNGI}

look for these. Of recent years also our foreign immigrants may sometimes be seen searching for and gathering fungi which were familiar to them in their native land.

Of course, the chief cause of this general neglect of fungi as articles of food is the still pretty general notion that all toadstools are poisonous. Recent research has shown that mushrooms of all kinds have nutritive qualities much inferior to what was at one time supposed to be the case; but in this respect they probably stand as high, while they have at least as conspicuous gastronomic attractions, as the universal turnip. There seems to be no good reason why the general advance in nature study should not bring us to a sufficient knowledge of the fungi to enable us to use the good and to know and eschew the few poisonous or deleterious ones which grow amongst the good.

\section{Poisonods Species.}

Some really poisonous species, of course, there are, and, until the recognition of them forms part of ordinary rural lore, any general use of wild-growing fungi as articles of food need not be hoped for. Almost every year, about the month of September, the newspapers report a case or two of fatal mushroom poisoning. It would seem that Amanita phalloides is, in all cases, the culprit. In the district with which we are at present concerned, lying within a radius of fifty miles from Toronto, there would 


\section{NATURAL HISTORY, TORONTO REGION}

seem to be not more than two or three species which are likely to be taken for edible mushrooms but are poisonous. There are several more or less hurtful species which by their peculiar appearance or disagreeable taste warn off or offer no temptation to the experimenter. The Fly Agaric (Amanita muscaria) and Amanita phalloides (including all its varieties, and Amanita verna among them) are, so far as I bave discovered in the Toronto district, the only forms which are dangerous, and of these Amanita. muscaria raises a warning signal by its bright orange or yellow-orange colour, and is naturally avoided as a poisonous "toadstool." Both these species are extremely common in woody places near Toronto towards the end of August or during the first two weeks of September. The variety of Amanita phatloides, which has a brownish pileus, has probably been frequently mistaken by those who have no knowledge of the subject for the common field mushroom, with unfortunate and often fatal result; but any one who has eren a slight acquaintance with the botanical points of difference could soon without difficulty distinguish the one from the other. There is, however, some danger, it seems to me, that an inaccurate beginner in the study of fungi may from insufficiently careful examination mistake the white varieties of Amanita phalloides for Lepiota naucinoides, where they are together in the collection basket, or where from some accidental cause the one has trespassed on the domain of the other. Young specimens, too, 


\section{MUSHROOMS AND OTHER FUNGI}

of Agaricus silvicola or Agaricus silvaticus suffciently resemble some forms of Amanita phalloides as to make great care necessary in eating them.

\section{Mushroom Celtivation.}

Not long ago it was reported that in France a commercially successful experiment had been made in cultivating Pleurotus cornucopicides, a fungus normally growing on wood, but not, so far as I know, found in Canada. In this country, howerer, no progress seems to be made in the cultivation of edible fungi, other than the common field mushroom, which alone is extensirely grown for the market. I have, indeed, from time to time seen in our shops for sale morels and not a few specimens of the shaggy-maned mushroom (Coprinus comatus), which latter went by the name of "French morels"; but I was not able to learn whence they were procured. Most likely they had been gathered by an unusually enterprising person from some favoured place where they were particularly abundant without artificial aids. Some such places I have occasionally seen, where for several years in succession a crop springs up sufficiently large to make it worth while gathering for near-by: family use, though not for the market.

Appended is a list (of course, far from complete) of fungi to be found near Toronto. It has been confined to those the identification of which has seemed to me to be satisfactory. For the most part, these are fungi of common occurrence in temperate coun- 


\section{NATURAL HISTORY, TORONTO REGION}

tries. I have been informed, however, by persons in the United States to whom I have sent specimens that the following are rather rare plants there: Polyporus squamosus, Pleurotus dryinus, Tremella frondosa, and Gyrocephalus rufus.

On the other hand, from what is said in popular handbooks, I should judge that there are elsewhere quite a number which are considered common species, but which I have met with either rarely or not at all. For example, the Beef-steak fungus (Fistulina hepatica), the edible qualities of which are so enthusiastically and tantalizingly lauded in the books, Clitopilus prunulus, Agaricus gambosus, Agaricus rubescens, Lepiota rachodes, Hygrophorus virgineus, Clitocybe illudens, and Armillaria mucida I have never seen; and Pleurotus ulmarius, Lactarius volemus, Russula virescens, Clitocybe nebularis, Clito: cybe clavipes, Clitocybe media and most species of Tricholoma, Volvaria and Cortinarius are rarities.

\section{PARTIAL LIST OF FUNGI TO BE FOUND NEAR TORONTO.}

BASIDIOMYCETES.

HYMENOMYCETES.

I Agaricaceae.

Leucosporae.

Amanita muscaria, Linn.

" phalloides, Fr.

Lepiota gracilenta, Krombh. 


\section{MUSHROOMS AND OTHER FUNGI}

\section{AGARICACEAE-(Continued).}

Leucosporae-(Continued).

Lepiota naucina (Fr.), or naucinoides (Pk.).

Armillaria mellea, Fr., Vahl. " procera, Scop.

Tricholoma album, Schaeff.

66 personatum, Fr.

Clitocybe amethystina, Bolt.

" clavipes, Pers.

" decastes, Fr.

" gilva, Pers.

" infundibuliformis, Schaeff.

“ laccata, Swp.

" media, $\mathrm{Pk}$.

" nebularis, Batsch.

" ochropurpurea, Berk.

" robusta, $\mathrm{Pk}$.

Collybia confluens, Pers.

“ dryophila, Bull.

" longipes, Bull.

" platyphylla, Fr.

“ radicata, Relh.

" velutipes, Curt.

Mycena galericulata, Scop.

Omphalia campanella, Batsch.

“ epichysia, Pers.

“ umbellifera, Linn.

Pleurotus dryinus, Pers.

" ostreatus, Jacq. 


\section{NATURAL HISTORY, TORONTO REGION}

I Agaricaceae-(Continued).

Leucosporae-(Continued).

Pleurotus petaloides, Bull.

" sapidus, Kalchb.

" serotinus, Fr.

“ sulphureoides, Pk.

“ ulmarius, Bull.

Hygrophorus miniatus, Fr.

Lactarius deliciosus, Fr.

66

piperatus, Scop, Fr.

" theiogalus, Fr.

" torminosus, Fr.

Russula aurata, Fr.

“ atropurpurea, $\mathrm{Pk}$.

" cyanoxantha, Schaeff, Fr.

" emetica, Fr.

" foetens, Fr.

" heterophylla, Fr.

" roseipes, Secr., Bres.

" virescens, Schaeff., Fr.

Cantharellus cibarius, Fr.

"

floccosus, Schw.

" lutescens, Bull.

Marasmius oreades, Fr.

Lentinus lecomtei, Fr. (also called Panus rudis).

" lepidens, Fr.

Panus strigosus, B. \& C.

" stypticus, Fr. 


\section{MUSHROOMS AND OTHER FUNGI}

I AgaricaCeAE-(Continued).

Leucosporae-(Continued).

Schizophyllum commune, Fr.

Lenzites betulina, Fr.

\section{Rhodosporae.}

Volvaria bombycina, Schaeff.

Pluteus cervinus, Schaeff.

Clitopilus caespitosus, Pk.

Claudopus nidulans, Pers.

\section{Ochrosporae.}

Pholiota adiposa, Fr.

"6

$$
\text { praecox, Pers. }
$$

Naucoria semiorbicularis, Bull.

Galera tenera, Schaeff.

Crepidotus versutus, $\mathrm{Pk}$.

Cortinarius alboviolaceus, Pers.

"

collinitus, Fr.

66

squamulosus, $\mathrm{Pk}$.

Paxillus atromentosus (Batsch), Fr.

" involutus (Batsch), Fr.

\section{Porphyrosporae.}

Agaricus campester, Linn.

“ magnificus, $\mathrm{Pk}$.

" silvaticus, Schaeff.

" silvicola, Vett.

Stropharia semiglobata, Batsch.

Hypholoma appendiculatum, Bull.

" incertum, $\mathrm{Pk}$.

" sublateritium, Schaeff. 


\section{NATURAL HISTORY, TORONTO REGION}

I Agaricaceae-(Continued).

Melanosporae.

Coprinus atramentarius, Bull. (Fr.)

" comatus, Fr.

" fimetarius, Fr.

" micaceus (Bull.), Fr.

Panaeolus retirugis, Fr.

II Polyporeaceae.

Boletinus pictus, $\mathrm{Pk}$.

Boletus americanus, $\mathrm{Pk}$.

" edulis, Bull.

" felleus, Bull.

" ravenelii, B. \& C.

" scaber, Fr.

Polyporus adustus, Fr.

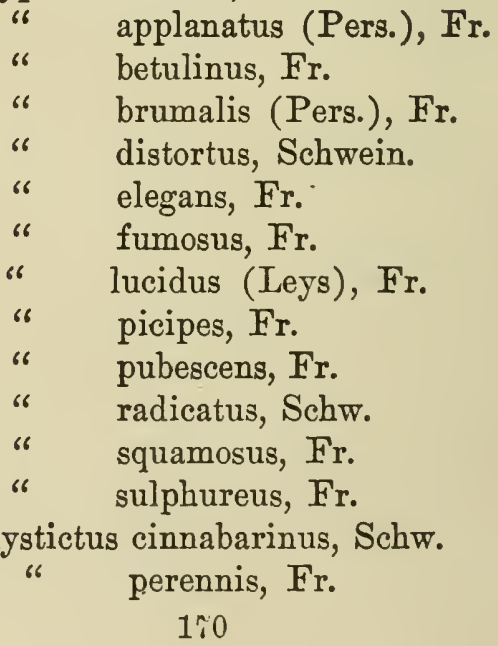

Polystictus cinnabarinus, Schw. 


\section{MUSHROOMS AND OTHER FUNGI}

II Polyporeaceae-(Continued).

Polystictus versicolor (L.), Fr.

Daedalea confragosa, Pers.

" unicolor, Fr.

" quercina, Pers.

Favolus europaeus, Fries.

Fomes fomentarius, Fr.

III HYDACEAE.

Hydnum albonigrum, $\mathrm{Pk}$.

" caput-ursi, Fr.

" coralloides, Scop.

" repandum, L.

Irpex lacteus, Fr.

Phlebia radiata, Fr.

iV Thelephoraceat.

Craterellus cornucopioides, Fr.

Thelephora schweinitzii.

Stereum hirsutum, Fr.

" frustulosum, Fr.

" rufum, Fr.

" sericeum, Schw.

" spadiceum, Fr.

" tabacinum, Fr.

" versicolor, Fr.

$\nabla$ Clatariaceae.

Clavaria aurea, Schaeff. " ligula, Fr.

Physalacria inflata, Schw. 
VI Tremellaceae.

Tremella frondosa, Fr.

" mycetophila, $\mathrm{Pk}$.

Tremellodon gelatinosum, Pers.

Gyrocephalus rufus (Jacq.) Bref.

\section{GASTEROMYCETES.}

I ITCOPERDACEAE.

Geaster limbatus, Fr.

" triplex, Jungh.

Calvatia cyathiformis, Batsch.

" gigantea, Batsch.

Lycoperdon gemmatum, Batsch.

iI Phalloideae.

Phallus impudicus, $\mathrm{L}$.

" ravenelli, B. \& C.

\section{ASCOMYCETES.}

I Sphertaceae.

Xylaria polymorpha, Grev.

Daldinia concentrica, Ces. et de Not.

Hypoxylum coccineum, Bull.

iI Helotiaceae.

Chlorosplenium versiforme, Pers.

III Pezizaceae.

Peziza scutellata, Linn. 


\section{MUSHROOMS AND OTHER FUNGI}

iv Geoglossaceae.

Microglossum rufum, Underw.

Gleoglossum difforme, Dur.

$$
\text { " } \quad \text { intermedium, Dur. }
$$

Trichoglossum hirsutum, Boud.

Spathularia clavata, Sacc.

Leotia chlorocephala, L. \& S.

" lubrica, Pers.

$\nabla$ Helvellaceae.

Morchella conica, Pers.

" esculenta, Pers.

Gyromitra esculenta, Fries.

" sphaerospora, Sacc.

Verpa bohemica, Schroet.

" conica, Swartz.

Helvella atra, Koenig.

" crispa, Fries.

“ elastica, Bull.

" infula, Shaef.

" lacunosa, Afz.

\section{REFERENCES.}

Atkinson-Mushrooms, Edible, Poisonous, etc. (Hy.

Holt \& Co., N.Y.).

McIlwaine \& Macadam-One Thousand American

Fungi (Bobbs, Merrill Co., Indianapolis). 


\section{CHAPTER X. \\ THE A L G A . \\ By \\ J. H. FAULL, Ph.D.}

THe following has been compiled mainly from Professor Mackenzie's list, which unfortunately has never been extended. Some few forms have been added; these are marked with an asterisk. It is quite needless to say that this list records but a small part of the algal flora in a district so favourably situated as is Toronto.

\section{CYANOPHYCEAE-The Blue-green Algae.}

Nearly all of the blue-greens mentioned have been taken from Howard Lake in High Park.

\section{Family Chroococcaceae.}

Chroococcus turgidus, Naeg. Merismopedium glaucum, Naeg.

Family Chamaesiphonaceae.

Chamaesiphon incrustans, Grunow.* Abundant on filaments of Cladophora, Toronto Island.

Family Oscillatoriaceae.

Oscillaria percursa, Kuetz.

" princeps, Vauch. 


\section{THE ALGAE}

Oscillaria limosa, Agardh.

Phormidium autumnale, Gomont.

\section{Family Nostocaceae.}

Nostoc ellipsosporum, Rab.* Toronto Island, on ground in marshy places.

" commune, Vauch.

" caeruleum, Lyng.

" pruniforme, Agardh.* Forming dark blue-

green or blackish-green floating balls, sometimes as large as a small hen's egg. Don Valley.

Anabaena flos-aquae, Bréb.

" azollae, Stras.* Greenhouse, in tissues of the little floating fern Azolla.

Cylindrospermum stagnale, B. \& F.

\section{Family Scytonemaceae.}

Tolypothrix lanata, Wart.

\section{Family Rivulariaceae.}

Calothrix fusca, B. \& F.

Rivularia dura, Roth.

"6 natans, Welwitsch.*

DIATOMIACEAE-Diatoms.

Species of the following genera of diatoms have been reported by W. B. Tindall, Esq. :

Stauroneis, Pinnularia, Navicula, Surirella, Meridion, Diatoma, Pleurosigma, Epithema, Gomphonema, Cocconeis, Bacillaria. 
NATURAL HISTORY, TORONTO REGION

\section{CHLOROPHYCEAE-Green Algae.}

Order Confervales (Heterocontae).

\section{Family Botrydiaceae.}

Botrydium granulatum, Grev.* Don Valley.

Order Conjugales.

\section{Family Desmidiaceae.}

Fifty-six species are listed by Mackenzie - all from Ashbridge's Bay, High Park, Don Valley and Humber Valley. The genera represented are:Hyalotheca (1 species), Desmidium (1), Penium (2), Closterium (12), Docidium (2), Calocylindrus (2), Cosmarium (19), Xanthidium (2), Arthrodesmus (1), Euastrum (2), Micrasterias (1), Staurastrum (11).

\section{Family Zygnemaceae.}

Zygnema pectinatum, var. anomalum, Kirch. Spirogyra flavescens, Cleve.

$\begin{array}{ll}\text { “ } & \text { longata, Kg. } \\ \text { " } & \text { jitida, Link. } \\ \text { " } & \text { ortholis, Kg. } \\ \text { " } & \text { quadrata, Petit. }\end{array}$

Family Mesocarpaceae.

Mongeotia genuflexa, Agardh.

Order Volvocales.

Family Chlamydomonadaceae.

Chlamydomonas-undetermined species. Haematococcus pluvialis, Agardh. 


\section{THE ALGAE}

\section{Family Volvocaceae.}

Gonium pectorale, Mueller.

Pandorina morum, Borg.

Eudorina elegans, Ehr.

Volvox globator, L.

Volvox aureus, Ehr.* In pools at Lorne Park.

\section{Order Protococcales.}

\section{Family Protococcaceae.}

Characium naegelii, A. Br.

\section{Family Scenedesmaceae.}

Zoochlorella parasitica, Brandt.* The cause of the green color of fresh-water sponges. Howard Lake and elsewhere.

Rhaphidium falcatum, Cooke. Often so abundant in aquarium jars as to color the water dark green.

Tetraedron gigas, Wittr.

Scenedesmus obliquus, Kutz.

" bijuga, Wittr.*

" quadricauda, Bréb.

\section{Family Hydrodictyaceae.}

Hydrodictyon reticulatum, Lager.* In a stream running from Don Brick Works. Abundant in creek at Acton West, northwest of railroad station.

Pediastrum boryanum, Menegh. 


\section{NATURAL HISTORY, TORONTO REGION}

\section{Order Ulotrichales.}

Family Ulotrichaceae.

Ulothrix zonata, Aresch.

\section{Family Oedogoniaceae.}

Oedogonium crassiusculum, Wittr. Bulbochaete intermedia, DeBary.

"6 gigantea, Pringsh.

Family Chaetophoraceae.

Chaetophora incrassata, Hazen. “ elegans, Agardh.* In pools at Lorne Park.

Stigeoclonium nanum, Kütz. (?)

Draparnaldia glomerata, Agardh.

Pleurococcus vulgaris, Men. Constitutes the green coating on tree trunks, damp walls, etc., everywhere.

Gloeocystis fenestralis, A. Braun.* In greenhouse. Chaetosphaeridium globosum, Klebahn.

Family Coleochaetaceae.

Coleochaete scutata, Bréb. On under surface of lily pads, etc.

Order Siphonales.

Family Vaucheriaceae.

Vaucheria dillwynii, Ag.

$\begin{array}{ll}\text { “ } & \text { ornithocephala, Ag. } \\ \text { “ } & \text { sessilis, D.C. } \\ \text { “ } & \text { geminata, D.C. } \\ & \text { terrestris, D.C.* }\end{array}$




\section{THE ALGAE}

Dichotomosiphon tuberosus, Ernst.* This comparatively rare plant was found by the writer in Wilcox Lake.

Order Siphonocladiales.

Family Cladophoraceae.

Cladophora fracta, $\mathrm{Kg}$. glomerata, $\mathrm{Kg}$.

Order Charales.

Family Characeae.

Chara foetans.* In great abundance in Howard Lake, Toronto Island, and elsewhere. Probably other species as well.

" spec.*

Nitella flexilis.*

" batrachospermum.* Found repeatedly in a small pond on Toronto Island, southwest of Lakeside Home.

\section{REFERENCES.}

Mackenzie, J. J. A Preliminary List of Algae Collected in the Neighbourhood of Toronto. Proc. of the Can. Inst., Toronto. 3rd Ser., vol. VII, p. 270.

Collins, F. S. The Green Algae of North America. Tufts College Studies, vol. II, No. 3. Tufts College, Mass.

Tilden, J. Minnesota Algae, vol. I (The Blue-green Algae of North America). 


\section{GHAPTER XI.}

\section{LICHENS.}

By

J. H. FAULL, Ph.D.

The lichens of Eastern and parts of Northern Ontario have received fairly complete treatment at the hands of Professor John Macoun in his "Catalogue of Canadian Plants, Part VII," to which acknowledgments are here made. Of the area covered by Professor Macoun the part of main interest to us lies in the territory bordering on the northeastern end of Lake Ontario. The southern portions of Northumberland and Hastings Counties, especially in the neighborhood of Belleville and Brighton, have been worked over very thoroughly. West of Toronto some information has been contributed by several collectors, but most of all by Mr. James White, who made his collections in Snelgrove, a rural district of cultivated, forest, swamp, and sphagnum bog land lying in the vicinity of Brampton. As Toronto lies between the two in practically uninterrupted continuity with both as regards soil, climate and topography, a departure has been made in this one group, in the absence of a list relating solely to Toronto, by going somewhat farther afield. Where the locality is not credited in the accompanying com- 


\section{LICHENS}

pilation the record is for the eastern Lake Ontario district already referred to. It is scarcely necessary to remark that as lichens are extremely sensitive to smoke and most gases it is necessary to go outside the city limits and beyond the influence of furnace smoke and factory fumes to find them.

\section{Family Graphidaceat.}

Graphis scripta var. limitata Schaer. Trees. Very common.

Arthonia astroidea Ach. On trees. Common. " lecideella Nyl. Trees.

" spectabilis Flot. On trees.

\section{Family Gyauectaceae.}

Conotrema urceolatum (Ach.) Tuckerm. Poplar.

\section{Family Lecideaceae.}

Biatora atropurpurea (Schaer.) Mass. Beech. " berengeriana Th. Fr. On earth. " cyrtella (Ach. Nyl.) Tuckerm. Trees.

" hypnophila (Turn.) Tuckerm. Bases of trees.

" laureri (Hepp.) Tuckerm. On beech at St. Catharines and Niagara Falls.

" rubella (Ehrh.) Rabenh. Trees.

" sanguineo-atra (Fr.) Tuckerm. Moss at bases of trees.

“ suffusa Fr. On trees throughout Ontario. 


\section{NATURAL HISTORY, TORONTO REGION}

Biatora schweinitzii Fr. Trees.

" varians (Ach.) Tuckerm. Trees.

Lecidea tessellina Tuckerm. On boulders.

Buellia parasema (Ach.) Th. Fr. Dead wood and old rails.

“ petraea (Flot.) Tuckerm. Granite boulders. “ schaereri De Not. Old rails.

Family Cladoniaceae.

Cladonia cariosa (Ach.) Spreng. Earth.

" cristatella Tuckerm. Dead wood. Very common.

“ fimbriata (Linn.) Fr. On earth at Snelgrove.

" fimbriata var. tubaeformis. Fr. Earth and rotten logs.

" furcata var. crispata Floerk. Earth in woods.

“ furcata var. pungens Fries. Earth.

" furcata var. racemosa Floerk. On earth in woods at Queenston Heights and Belleville.

" gracilis var. hybrida Schaer. On rotten logs at Snelgrove and Credit Forks. " mitrula, Tuckerm. On earth in pine woods. " pyxidata (Linn.) Fr. On rocks, logs, earth at Snelgrove and Credit Forks.

" rangiferina (Linn.) Hoffm. On ground at Snelgrove and Credit Forks. Exceedingly abundant farther to the north in Ontario. 


\section{LICHENS}

Cladonia sylvatica Linn. Earth.

“ turgida (Ehrh.) Hoffm. Earth in damp woods.

“ uncialis var. adunca Fr. Earth.

\section{Family Stereocaulaceae.}

Pilophorus cereolus var. fibula Tuckerm. Rocks.

\section{Family Collemaceae.}

Collema pulposum (Bernh.) Nyl. Earth. Leptogium chloromelum (Sw.) Nyl. Trees. " lacerum (Sw.) Fr. On rocks. " myochroum (Ehrh.) Tuckerm. Trees. “ pulchellum (Ach.) Nyl. On trees in woods.

“ tremelloides (Linn. f.) Fr. Trees and rocks.

Family Stictaceae.

Sticta amplissima (Scop.) Mass. On trees at Niagara Falls and Belleville. “ pulmonaria (Linn.) Ach. Throughout Ontario.

Family Peltigeraceae.

Nephroma laevigata Ach. On boulders in woods. " tomentosa (Hoffm.) Koerb. Peltigera aphthosa (Linn.) Hoffm. Common. 183 


\section{NATURAL HISTORY, TORONTO REGION}

Peltigera canina (Linn.) Hoffm. On earth in woods everywhere.

6

polydactyla (Neck) Hoffm. On ground at Snelgrove.

“ rufescens (Neck) Hoffm. On ground and mossy hummocks at Snelgrove and Solorina saccata (Linn.) Ach. On limestone rocks. Credit Forks.

Family Lecanoraceae.

Lecanora athroocarpa (Dub.) Nyl. Beech and maple. “ atra (Huds.) Ach. Old rails. “ gibbosa $\mathrm{Nyl}$. Old cedar rails. " hageni Ach. Fence rails and bark.

" pallescens (Linn.) Schaer. Trees.

“ pallida (Schreb.) Schaer. On tree trunks at Niagara Falls.

" subfusca var. allophana Ach. On beech trees at Snelgrove.

“ varia (Ehrh.) Nyl. Old fence rails.

“ varia var. saepineola Fr. Cedar rails and boards.

\section{Family Pertusariaceate.}

Pertusaria communis DC. Beech.

" multipuncta (Turn.) Nyl. Trees.

" pustulata (Ach.) Nyl. Trees.

“ velata (Turn.) Nyl. Trees and fence rails. 


\section{LICHENS}

\section{Family Parmeliaceae.}

Ramalina calicaris var. farinacea Schaer. Trees.

"6

calicaris var. fastigiata

(Pers.) Fr.

Fence rails.

" calicaris var. fraxinea Fr. Fence rails.

Cetraria ciliaris (Ach.) Tuckerm. Fence rails, stumps, trees.

“ lacunosa Ach. Fence rails.

Evernia prunastri (Linn.) Ach. Fence rails.

Usnea barbata var. hirta Fr. Fence rails.

" barbata var. rubiginea Michx. Trees in swamps.

Parmelia borreri var. rudecta Tuckerm. B ark.

Niagara Falls.

“ caperata (Linn.) Ach. On old fences and tree trunks near Hamilton.

“ crinita Ach. Old rails and trees.

" olivacea var. sorediata (Ach.) Nyl. On fence rails and rocks near Galt.

“ perforata (Jacq.) Ach. Trees.

“ perlata (Linn.) Ach. Trees and old rails. " physodes var. vulgaris Korb. Trunks and fence rails.

“ saxatilis (Linn.) Fr. Old rails and trees.

Family Teloschistaceae.

Teloschistes chrysophthalmus (Linn.) Norm. Trees and fence rails along Lake Erie and Lake Ontario. 
Teloschistes concolor (Dicks.) Tuckerm. Trees. " parietinus (Linn.) Norm. Trees. “ polycarpus (Ehrh.) Tuckerm. Trees. Placodium cerinum (Hedw.) Naeg. and Hepp. Aspen.

“ vitellinum (Ehrh.) Naeg. and Hepp. Common on old rails.

Family Physciaceae.

Physcia aquila var. detonsa Tuckerm. On beech trees at Snelgrove.

“ ciliaris var. crinalis Schaer. Dead wood.

“ hispida (Schreb.) Tuckerm. On boulders, fence rails and trees.

“ obscura (Ehrh.) Nyl. On trees and fence rails.

“ pulverulenta (Schreb.) Nyl. Trees.

“ setosa (Ach.) Nyl. On trunks in woods.

“ stellaris (Linn.) Tuckerm. On trees and rails.

“ stellaris var. aipolia Nyl. On maple and ash, Snelgrove.

Pyxine sorediata Fr. Dead wood, beech trees and old rails.

Rinodina ascociscana Tuckerm. Beech.

“ sophodes (Ach.) Nyl. Maple.

“ sophodes var. confragosa Nyl. Maple.

" sophodes var. exigua Fr. Old fence rails. 


\section{LICHENS}

Family Prrenulaceae.

Pyrenula gemmata (Ach.) Naeg. and Hepp. Trees. " hyalospora ( $\mathrm{Nyl}$.) Tuckerm. Trees. “ leucoplaca (Wallr.) Koerb. Trees.

\section{REFERENCES.}

Fink. The Lichens of Minnesota. Smithsonian Inst. Washington. 1910.

Tuckerman. North American Lichens. Boston. 1882.

Schneider. A Text-book of General Lichenology. Binghampton, N.Y. 1897. 


\title{
CHAPTER XII.
}

\section{MYCETOZOA OR SLIME-MOULDS.}

By

\author{
J. H. FAULL, Ph.D.
}

A COLLection of the fruiting bodies of these curious and fascinating forms of life-plant, or animal, or neither, according to the point of view taken-has been accumulating in the Herbarium of the University of Toronto, and it is from these that the following partial list is compiled. So far nothing on the Slime-Moulds of Ontario has been published. W. G. Scrimgeour, M.A., a graduate student, worked over a considerable mass of material in the University Herbarium, and embodied the results of his labours in a Master's thesis-now on file in the library. The publication of his paper was deferred until a wider area of the Province had been explored. It will doubtless appear in time. Several local collectors have made contributions, and these have been highly valued. Slime moulds are easily gathered and require nothing more than careful handling. For transporting or mailing, the pieces of substratum to which they adhere should be firmly glued or sewn to the bottom of a pasteboard box-nothing more.

As the number of bona fide species described from the North Temperate Zone is not more than 


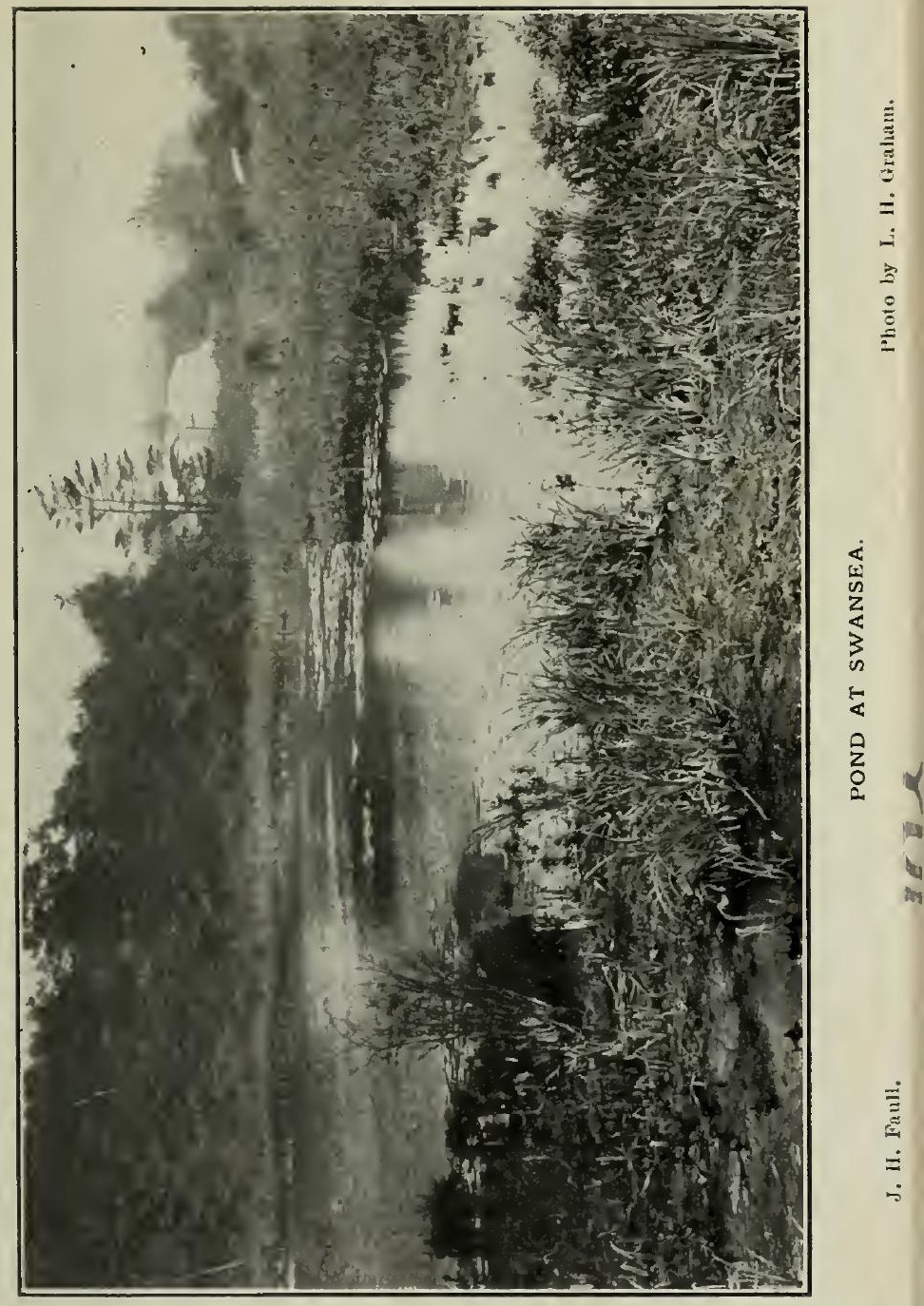





\section{MYCETOZOA, OR SLIME MOULDS}

three hundred, it is quite within reason to believe that one-third of these are represented within easy collecting distance of the city. Specimens of the forms marked with an asterisk were found in High Park.

\section{Ceratiomyxaceae,}

Ceratiomyxa fruticulosa, Macbr.*

66

66
66

66 var. flexuosa, Lister.

var. porioides,

Lister.

\section{Physaraceae.}

Badhamia utricularis, Berk.

" species.*

Physarum compressum, Alb. and Schw.*

66

66

66

66

66

66

66

66 lateritium, Morg. .

pusillum, Lister.*

flavicomum, Berk.*

sinuosum, Weinm.*

viride, Pers.*

species.*

species.*

globuliferum, Pers.*

Leocarpus fragilis, Rost.*

Diderma globosum, Pers.

66

testaceum, Pers.*

66

spumarioides, Fr.*

Fuligo septica, Grmelin.*

Diachaea leucopoda, Rost.

Craterium lencocephalum, Ditm.* 


\section{NATURAL HISTORY, TORONTO REGION}

\section{Didymiaceae.}

Didymium nigripes, Fries.

“ $\quad$ squamulosum, Fr.* ${ }^{*}$

Mucilago spongiosa, Morgan.

\section{Stemonitaceae.}

Stemonitis fusca, Roth.*

"

splendens, Rost.

" herbatica, Peck.

Comatricha nigra, Schroeter.*

"6 typhoides, Rost.*

6 species.*

\section{Amaurochaetaceae.}

Brefeldia maxima, Rost.*

A magnificent specimen nearly eight inches in diameter was found on an oak stump in High Park, October, 1906.

\section{Heterodermaceae.}

Cribraria macrocarpa, Schrad.*

" aurantiaca, Schrad.*

“ splendens, Pers.*

Dictydium cancellatum, Macbr.*

\section{Tubulinaceae.}

Tubifera ferruginosa, Gmel.*

“ stipitata, Macbr.

A very characteristic specimen of this unusual species was recently collected and presented by T. Langton, Esq., K.C. 


\section{MYCETOZOA, OR SLIME MOULDS}

\section{Reticulariaceae.}

Dictydiaethalium plumbeum, Rost.

This form has been collected by the writer several times at York Mills.

Enteridium rozeanum, Wing.*

The subglobose or pulvinate fruiting bodies often attain a diameter of one inch. They are almost invariably conspicuously parasitized by some insect in this locality. This is true of no other species of slime mould.

Reticularia lycoperdon, Bull.

\section{Lycogalaceae.}

Lycogala flavo-fuscum, Rost.

" epidendrum, Fries.*

\section{Trichiaceae.}

Trichia varia, Pers.*

" decipiens, Macbr.*

" persimilis, Karst.*

" scabra, Rost.*

" botrytis, Pers.

Oligonema flavidum, Peck.

Hemitrichia clavata, Rost.*

6

66

6 vesparium, Macbr.

serpula, Rost.

stipata (Schw.), Macbr.* 


\section{Arcyriaceae.}

Perichaena corticalis, Rost.*

$$
\begin{array}{cl}
\text { Arcyria } & \text { stipata, Lister.* } \\
\text { “ } & \text { cinerea, Pers. } \\
\text { " } & \text { oerstedtii, Rost. } \\
\text { " nutans, Grev.* } & \text { denudata, Sheldon.* } \\
\text { “ } & \text { digitata, Rost. } \\
\text { “ } & \text { incarnata, Pers.* }
\end{array}
$$

\section{REFERENGES.}

Lister. A Monograph of the Mycetozoa (Longmans \& Co., London).

Macbride. North American Slime-Moulds (Macmillan $\mathrm{Co}$.). 


\section{CHAPTER XIII.}

\section{INSECT GALLS OF THE VICINITY OF TORONTO.}

By

A. COSENS, M.A., Ph.D.

THE term "gall" is applied to any enlargement of plant cells, tissues, or organs induced by the stimulus of a parasitic organism as a regular incident in the life history of the parasite.

Galls are divided into two classes according to the agent that produces the stimulus, namely Phytocecidia, those owing their origin to parasitic plants, and Zoocecidia, those produced by animal parasites.

From the Bryophytes to the Spermatophytes nearly all plants are subject to gall formations of the latter class. These are incited by mites (Acarina) and by insects in several different orders as follows:

Hemiptera (Families Aphididae, Psyllidae), Diptera (Families Cecidomyidae, Trypetidae), Coleoptera (Families Buprestidae, Cerambycidae, Curculionidae), Lepidoptera (Families Gelechiidae, Sesiidae, Tineidae), Hymenoptera (Families Cynipidae, Tenthredinidae).

The type of gall produced by the onders Acarina and Hemiptera is simple in structure, consisting usually of a more or less pronounced folding in the 13 


\section{NATURAL HISTORY, TORONTO REGION}

leaf of the host, and often accompanied in the former by an abundant production of trichomes. The Coleoptera and Lepidoptera originate galls that show little differentiation of tissues and an entire lack of a well-defined nutritive layer. The Dipterous forms are in some cases as simple in structure as the Acarina pouch galls, but in others are as complicated as any of the highest types of galls. In the order Hymenoptera are two families, Cynipidae and Tenthredinidae (Sawflies), the members of which produce galls that are in marked contrast to each other. The Sawfly galls are characterized by a very pronounced proliferation of tissue without differentiation into distinct layers except at the very earliest stages of gall production. The Cynipid galls, by way of contrast, have invariably three distinct zones of tissues, and only seldom is a fourth absent. These layers have the following relation to each other. Lining the larval chamber is the nutritive zone with cells oriented usually in a radial direction. Bounding this layer on the outside is situated the protective sheath, the zone that is absent in a few types. Outside of that again the parenchyma or tannin zone is differentiated, passing out to the epidermal layer.

With respect to the stimulus that incites the abnormal production of tissues these galls are also markedly different. Sections of the Sawfly galls show the egg of the producer still unhatched even after gali production has advanced to a considerable degree, a very plausible argument that the stimulus 


\section{INSECT GALLS}

is originated by the act of ovipositing. In the case of the Cynipid galls, however, it has been clearly demonstrated that gall production does not commence until the larvae begin to feed.

The following is a list of some of the commoner species of Zoocecidia found in this locality:

\section{Order Acarina.}

A large number of the galls in this group are still unclassified, but the type characters are well marked. The different species constitute a clear phylogenetic series from the simple erineum to the well-developed pouch gall. The distinction between the different members of this series is largely a difference in degree rather than in kind, and seems to be explainable on the assumption of a gradually increasing intensity of stimulus from the lowest to the highest member of the series. A simple erineum type is that found on the underside of the leaves of Fagus grandifolia, Ehrh., while Eriophyes abnormis, a pouch gall on the leaves of Tilia americana, L., stands at the other end of the series. As an average between these extremes may be placed such a form as the "dimple" gall on the leaves of Quercus macrocarpa, Michx.

\section{Order Hemiptera.}

These galls are characterized by a folding and wrinkling of the leaf when they occur on that organ, and in this particular resemble the types of the preceding section. 


\section{NATURAL HISTORY, TORONTO REGION}

Hormaphis hamamelidis, Fitch, and Hamamelistes spinosus, Shimer, are common on the witch hazel near the city. The former is a conoidal leaf gall, while the latter is a somewhat elliptical spiny structure originated from a flower bud.

Pemphigus vagabundus, Walsh, is a very conspicuous gall at all seasons of the year on cottonwood, Populus deltoides, Marsh. The leaf petioles of the same host are often twisted and enlarged by Pemphigus populicaulis, Fitch.

Colopha ulmicola, Cockscomb-elm gall, Fitch, is not uncommon. It deforms the leaves of the American elm, Ulmus americana, $\mathrm{L}$.

Four species of Chermes affect the spruces of this region, namely, Chermes abietis, Chol., on Norway spruce (Picea abies, Karst) and Black spruce (Picea mariana, B.S.P.), and Chermes floccus, Patch, Chermes similis, Gill., Chermes pinifoliae, Fitch, on Black spruce.

\section{Order LEPIDOPTERA.}

These galls are produced almost invariably as a spindle-shaped swelling of the stem of the bost. They are so conspicuous on account of their size that they often attract attention.

Eucosma scudderiana, Clemens, on the goldenrods, Solidago canadensis, L., and Solidago serotina var. gigantea, Gray (seldom). This gall occurs high up on the stem of the host among the branches. The 


\section{INSECT GALLS}

producer passes the winter in the larval form and emerges in June.

Gnorimoschema gallaesolidaginis, Riley. The hosts are the same as in the preceding species. The producer emerges in August and winters in the imago form.

Gnorimoschema gallaeasterella, Kellicott, on the golden-rods Solidago latifolia, L., and Solidago caesia var. axillaris, Gray (seldom). Resembles the former species closely in its life history. Both species of this genus are originated on the lower half of the stem of the host.

Stagmatophora ceanothiella, Cosens. Host Ceanothus americanus, L. Usually found terminal on the stem of New Jersey Tea, in which case the flower cluster is aborted. The producer passes the winter in the larval state and emerges in June.

\section{Order Diptera.}

Cecidomyia bulla, Walsh, on the sunflowers Helianthus decapetalus, I., and Helianthus divaricatus, L. Occur usually on the stem of the hosts as small flask-shaped swellings.

Cecidomyia balsamicola, Lintner. Host Abies balsamea (L.), Mill. Consist of a slight enlargement of the needles of the balsam produced by a folding of these organs.

Cecidomyia impatientis, O.S. Host Impatiens biflora, Walt. A spherical, polythalamous gall attached to the host plant by a tapering stalk. 
Cecidomyia majalis, Bass. Hosts Quercus rubra, L., Quercus velutina, Lam. A flat, pouch-like gall on the under side of the leaves of the red and black oaks. It is clearly produced by a folding of the leaf, and in this respect resembles the Acarina and Hemipterous types.

Cecidomyia ocellaris, O.S. Host Acer rubrum, L. The red and yellow concentric rings of colour are a very noticeable feature of this gall. In a slight depression at the centre of these rings the larva rests covered with a viscid fluid secretion.

Cecidomyia pellex, O.S. Host Fraxinus americana, L. This gall is formed by a swelling of the blade of a leaflet on each side of the midrib of leaves of the white ash.

Cecidomyia triticoides, Walsh. Host Salix cordata, Muhl. A terminal gall produced by a swelling and shortening of the stem of this willow. The larval chambers are situated in the buds of the affected twigs.

Lasioptera impatientifolia, Felt. Host Impatiens biflora, Walt. A monothalamous gall consisting of a spindle-shaped enlargement of the midrib of leaves of the spotted touch-me-not.

Neolasioptera perfoliata, Felt. Host Eupatorium perfoliatum, L. A monothalamous gall on boneset, consisting of a spindle-shaped swelling of the stem. 


\section{INSECT GALLS}

Rhabdophaga batatas, Walsh. Host Salix humilis, Marsh. A nodule-like swelling of the stem of the prairie willow. Very variable in size and shape.

Rhabdophaga strobiloides, Walsh. Host Salix cordata, Muhl. A top-shaped mass of leaves, produced by a shortening of the stem axis of the host, constitutes the principal mass of this gall.

Eurosta solidaginis, Fitch. Host Solidago canadensis, L. The gall consists of a spherical swelling of the stem of this golden-rod. When dry it is pithlike in structure throughout.

\section{Order Coleoptera.}

Podapion gallicolla, Riley. Host Pinus resinosa, Ait. An ellipsoidal to spherical swelling of the branches of red pine.

Saperda concolor, Lec. Host Populus candicans, Ait. A more or less regularly ellipsoidal swelling of the stem or branches of the host. The producer emerges early in May.

\section{Order Hymexoptera. Family Tenthredinidae.}

Sawfly gall producers infest only the willows.

Euura Salix gemma, Walsh. Host Salix humilis, Marsh. This gall is produced by the swelling of a lateral bud.

Euura Salix ovum, Walsh. Host Salix cordata, Muhl. A monothalamous gall consisting of an elongated oval swelling on one side of a twig. 


\section{NATURAL HISTORY, TORONTO REGION}

Euura serissimae, Rohwer. Host Salix serissima, Fernald. Consists of the enlarged petiole of the leaf. The leaves infested are borne on the branchlets from which the pistillate catkins spring.

Pontania pisum, Walsh, Host Salix discolor, Muhl. An almost spherical, pea-like gall, with a small point of attachment to the leaf of the host.

Pontania pomum, Walsh. Host Salix cordata, Mubl. A large, globular gall originating from the leaf of the host. It is greenish-yellow in colour, usually with a rosy colour on one side.

Pontania crassicornis, Rohwer. Host Salix humilis, Marsh. Resembles the former species in shape, but is considerably smaller. It is densely pubescent, and several are crowded together on one leaf.

Pontania desmodioides, Walsh. Host Salix humilis, Marsh. A smooth, flattish gall with a semicircular outline originating from the mesophyll of the leaf.

Pontania hyalina, Norton. Host Salix alba, L. Many galls are produced on a leaf arranged in two almost parallel rows, one on each side of the midrib.

Pontania lucidae, Rohwer. Host Salix lucida, Muhl. Produced as an enlargement of the petiole or midrib of the leaf. A common gall in High Park.

\section{Order Hxmenoptera. Family Cynipidae.}

Our native oaks furnish the hosts for a large number of species in this family, and as a consequence they are well represented in our parks. 


\section{INSECT GALLS}

Amphibolips confluens, Harris, host Quercus velutina, Lam. Amphibolips inanis, O.S., host Quercus rubra, L. These species are the common large "oak apples." While very much alike in external form, the parenchyma zone in the former consists of a dense mass of interlocking fibres, while only a comparatively small number of delicate straight strands constitutes it in the latter.

Andricus singularis, Bassett. Host Quercus ru$b r a, \mathrm{~L}$. In size and external form this gall closely resembles Dryophanta palustris, O.S., but its larval chamber is supperted at the centre of the gall by radiating bands of tissue.

Andricus piger, Bassett, host Quercus velutina, Lam. Andricus petiolicola, Bassett, host, Quercus alba, L. These galls are both produced by the swelling of the midrib or petiole, but can be distinguished by means of the different hosts.

Aulacidea nabali, Brodie. Hosts Prenanthes alba, L., and Prenanthes altissima, L. A large spherical swelling of the base of the stem of two of our rattlesnake-roots, usually just below the ground.

Aulacidea tumida, Bassett. Host Lactuca canadensis, $\mathrm{L}$. This species produces an elongated swelling of the stem of the wild lettuce, situated near its summit, usually in the panicle.

Biorhiza forticornis, Walsh. Host Quercus alba, L. The individual gall is almost spherical in shape and has suspended at its centre by radiating fibres 


\section{NATURAL HISTORY, TORONTO REGION}

the single cell. The galls are found usually in dense masses around the stem, and are thus pressed into a somewhat elongated and flattened shape.

Cynips (?) constricta, Stebbins. Host, Quercus velutina, Lam. This gall has the form of a sphere surmounted by a short cylindrical portion slightly constricted at the base. It originates from the midrib or a principal vein of the leaf.

Diastrophus cuscutaeformis, O.S. Host Rubus villosus, Ait. Many galls are clustered together around the stem of dewberry. Each consists of a small, hard, spherical mass surmounted by a rosette of minute filaments.

Diastrophus turgidus, Bassett. Host Rubus idaeus var. aculeatissimus, Regel and Tiling. Irregular, pithy swellings surrounding the stem.

Diastrophus fusiformis, Ashmead. Host Potentilla monspeliensis var. norvegica (L.), Rydb. An elongated, fusiform swelling of the stem of this cinquefoil.

Dryophanta palustris, O.S. Hosts Quercus rubra, L., and Quercus velutina, Lam. One of our commonest Cynipid galls. Almost as soon as this gall emerges from the bud, the larval chamber separates from the remainder of the gall.

Holcaspis globulus, Fitch. Host Quercus alba, L., and Holcaspis mamma, Walsh. Host Quercus macrocarpa, Michx. The former species is a spherical gall produced at the nodes of the stem. The latter 


\section{INSECT GALLS}

differs from it only in ending in a short, tapering point.

Holcaspis bassetti, Gillette. Host Quercus macrocarpa, Michx. Produced in clusters surrounding the stem. When not deformed by crowding, the gall is circular in outline at the base, but tapers to a distinct point.

Philonix hirta, Bassett. Host Quercus macrocarpa, Michx. A spherical gall originating from the midrib of the leaf; its surface is faceted in appearance.

Philonix nigra, Gillette. Host Quercus alba, L. This species is also spherical in form, but the surface is felty in appearance, due to a dense pubescence.

Philonix erinacei, Beut. Host Quercus alba, L. Usually ellipsoidal in shape, springing from the midrib of the leaf. The surface is again in this case faceted, and each facet terminates in a distinct trichome.

On the hills of High Park a few specimens of Rosa blanda, Ait., are found. These plants act as hosts for a number of species of the genus Rhodites. Infesting the stems are found Rhodites multispinosus, Gillette, Rhodites globuloides, Beut., Rhodites dichlocerus, Harris, while from the root originates Rhodites radicum, O.S., and from the leares are produced Rhodites bicolor, Harr., Rhodites lenticularis, Bassett, Rhodites ignotus, O.S., Rhodites gracilis, Ashm., and Rhodites nebulosus, Bassett. Near the 


\section{NATURAL HISTORY, TORONTO REGION}

city the Sweet Brier, Rosa rubiginosa, L., has been practically exterminated by the ravages of Rhodites rosae, Linné., which produces on its stems the large moss-like galls.

Solenozopheria vaccinii, Ashmead. Host Vaccinium pennsylvanicum, Lam. Produced as a large reniform swelling of the stem of this blueberry, which is almost invariably bent at the point of attachment of the gall.

\section{REFERENCES.}

Cosens, A. A Contribution to the Morphology and Biology of Insect Galls. Trans. Can. Inst. IX. 1912.

Beutenmueller, William. Monographs of the Cynipidae. Amer. Mus. Nat. Hist., 1904-11.

Jarvis, T. D. Insect Galls of Ontario. Rep. Ent. Soc. Ont., 1907-8.

Patch, E. M. Chermes of Main Conifers. Maine Agr. Exp. Sta. Bull. No. 173, 1909.

Stebbins, F. A. Insect Galls of Springfield, Mass., and Vicinity. Springfield Mrus. Nat. His. Bull. No. 2, 1909. 


\section{CHAPTER XIV.}

\section{ZOOLOGY.}

Edited by

J. PLAYFAIR McMURRICH, Ph.D.

Is preparing this first list of the Fauna in the neighbourhood of Toronto it was fully recognized that while the lists of the Vertebrates could be made practically complete, and those of the Insects and Mollusca fairly so, great gaps must of necessity occur in those of the other groups of Invertebrates. It has seemed advisable, however, to place on record our scanty information concerning these last named groups, not only for the sake of completeness, but more especially in the hope that its very scantiness may stimulate the naturalists of the vicinity to make a special study of these hitherto neglected forms. Abundant and interesting results would undoubtedly follow from the study of such groups as the Ants, the Spiders, the Entomostracous Crustacea, the Earthworms and their allies, the Rotifers and the Infusoria, and it is to be hoped that when another edition of this list is prepared these groups may be fully represented.

The editor desires to thank those who have compiled the various lists that follow, for the care and promptitude with which they have accomplished their tasks, willingly undertaken. It is hoped that the brief bibliographical references appended to each list may be of use to those who may be desirous of undertaking faunistic work in this ricinity. 


\section{CHAPTER XV.}

\section{MAMMALS.}

\section{By \\ JAMES H. FLEMING.}

THis list is in part based on three small collections of mammals made in the immediate vicinity of Toronto; one, by Mr. Ernest T. Seton, made between 1SS7 and 1891, and now in the Victoria Memorial Museum, Ottawa; another, made by Mr. C. W. Nash, now in the Provincial Museum, Toronto; and, finally, my own collection.

A very important list was published by Dr. Anthony Gapper in the "Zoological Journal of London" in 1830 (Vol. V, pp. 201-207). According to the late Mr. John Hallam, Dr. Gapper came from England about 1825 and settled with his brother on lot 40 or 41 on the east side of Yonge Street, less than ten miles from the present city limits. $\mathrm{He}$ returned to England in 1831 after collecting considerable natural history material. In his paper four new mammals are described, and the list gives a clear idea of the conditions before the original forest had disappeared. For conditions between Dr. Gapper's time and recent years I have used information given me from time to time by the late Dr. William Brodie, and, finally, I have to thank Mr. Gerrit S. 


\section{MAMMALS}

Miller, Jr., for checking the nomenclature, which seems to be as fleeting in mammals as in birds.

\section{Marsupialia.}

1. Virginia Opossum. Didelphis virginiana virginiana Kerr. Accidental, one record.

\section{Ungulata.}

2. Northern Virginia Deer. Odocoileus virginianus borealis Miller. Formerly common, exterminated, records up to 1837 .

\section{Rodentia.}

3. Prairie Cottontail. Sylvilagus floridanus mearnsi Allen. Common, first records about 1884. ("Ottawa Naturalist," 1908, pp. 158-9.)

4. Southern Varying Hare. Lepus americanus virginianus (Harlan). Formerly common, only recently exterminated; still found just outside in limits of this list.

5. Jumping Mouse. Zapus hudsonius hudsonius (Zimmermann). Generally distributed, not very common.

6. Red-backed Mouse. Evotomys gapperi gapperi (Vigors). Described by Gapper in 1830; no recent records.

7. Meadow Mouse. Microtus pennsylvanicus pennsylvanicus (Ord). Abundant. 


\section{NATURAL HISTORY, TORONTO REGION}

8. Muskrat. Ondatra zibethica zibethica (Linnæus). Still common.

9. White-footed Mouse. Peromyscus leucopus noveboracensis (Fischer). Common. This is the Mouse-like Hampster, Cricetus myiodes of Gapper.

10. Canadian White-footed Mouse. Peromyscus maniculus gracilis (Le Conte). One record, Deer Park (now part of Toronto). N. A. Fauna 28, p. 45.

11. House Mouse. Mus musculus Linnæus. Introduced; very common according to Gapper in 1830.

12. Brown Rat. Epimys norvegicus (Ersleben). Introduced; had not penetrated further than the water front according to Gapper in 1830 .

13. Canadian Beaver Castor canadensis canadensis Kuhl. Once common; given by Gapper as very rare in 1830. A pair appeared in the grounds of Colonel Denison about 1884.

14. Woodchuck. Arctomys monax monax (Iinnæus). Common.

15. Chipmunk. Tamias striatus lysteri (Richardson). Very common.

16. Northern Grey Squirrel. Sciurus carolinensis leucotis (Gapper). Formerly common, becoming scarcer; the indigenous form was black, the grey animal on which Gapper founded his leucotis was rare, but it has become much commoner since then. The squirrels in High Park are black and have not been introduced.

17. Red Squirrel. Sciurus hudsonicus loquax Bangs. Very common. 
18. Flying Squirrel. Sciuropterus volans volans (Linnæus). Not very common.

\section{InsECTIVORA.}

19. Eastern Short-tailed Shrew. Blarina brevicauda talpoides (Gapper). Common. This is the Mole-like Shrew, Sorex talpoides, of Gapper.

20. Masked Shrew. Sorex personatus personatus I. Geoff. St. Hillaire. Not common. This is illustrated by Gapper as Forester's Shrewmouse, Sorex foresteri (Richardson).

21. Brewer's Mole. Parascalops breweri (Bachman). Rare. This is perhaps the mole referred to by Gapper as the Shrew Mole, Scalops canadensis (Cuvier) =Scalops aquaticus (Linnæus), which has not as yet been found here. Gapper's record was not based on personal knowledge.

22. Star-nosed Mole. Condylura cristata (Linnæus). Not uncommon.

\section{Chiroptera.}

23. Brown Bat. Eptesicus fuscus (Beauvois). Not very common, if the number of skins in collection is a safe indication.

24. Say's Bat. Myotis subulatus Say. Gapper says, "The most common Bat in the home district." Several specimens from the vicinity of Toronto are in the Museum of the Geological Survey at Ottawa, from the Seton collection. 


\section{NATURAL HISTORY, TORONTO REGION}

25. Silver-haired Bat. Lasionycteris noctivagans (Le Conte). Apparently common.

26. Red Bat. Nycteris borealis borealis (Mïller). Apparently common.

27. Hoary Bat. Nycteris cinerea (Beaurois). Rare.

\section{Carnivora.}

28. Otter. Lutra canadensis canadensis Schreber. Apparently rare in 1830, as Gapper had ouly seen skins, but according to the late Dr. Brodie the animal persisted till a very much later date.

29. New York Weasel. Mustela noveboracensis noveboracensis Emmons. Not very common.

30. Small Brown Weasel. Mustela cicognanii cicognanii (Bonaparte). Probably occurs; recorded by Gapper.

31. Mink. Mustela vison vison (Schreber). Still not uncommon.

32. Fisher. Martes pennanti pennanti Erxleben. One recorded by Gapper in 1830.

33. Pine Martin. Martes americana americana Turton. Recorded by Gapper in 1830 and, according to the late Dr. Brodie, common till a much later date.

34. Skunk. Mephitis mephitica mephitica (Shaw). Common. Gapper had seen only skins in 1830 .

35. Raccoon. Procyon lotor lotor (Linnæus). Still not uncommon. Listed by Gapper in 1830. 


\section{MAMMALS}

36. Black Bear. Ursus americanus americanus Pallas. Listed by Gapper in 1830, but probably not exterminated till much later.

37. Red Fox. Vulpes fulva fulva (Desmarest). Still common.

38. Grey Wolf. Canis lycaon Schreber. Gapper had seen only imperfect specimens, probably skins, in 1830 , but, according to the late Dr. Brodie, wolves occasionally drove deer into Markham as late as 1840.

39. Wild Cat. Lynx ruffus ruffus (Gueldenstaedt). One specimen taken at Scarboro was in the possession of the late Dr. Brodie, and I have seen others near Toronto, but it never was common.

40. Canadian Lynx. Lynx canadensis canadensis Kerr. One recent record; has never been more than a migrant.

41. Panther. Felis couguar Kerr. Accidental, one record. ("Biological Review of Ontario," 1894, pp. 18-23.)

\section{GENERAL REFERENCES.}

D. S. Jordan. Manual of the Vertebrates of the Northern United States. 1888.

C. W. Nash. Vertebrates of Ontario. Toronto, 1908.

Stone and Cram. American Animals. Toronto, 1902. 


\section{CHAPTER XVI.}

\section{B I R D S .}

By

JAMES H. FLEMING.

Family Coltrabidat.

1. Holbœll's Grebe. Colymbus holboelli. Regular migrant, not common.

2. Horned Grebe. Colymbus auritus. Regular migrant, common.

3. Pied-billed Grebe. Podilymbus podiceps. Regular migrant, common; probably breeds.

\section{Family Gavimate.}

4. Loon. Gavia immer. Regular migrant, usually not common.

5. Red-throated Loon. Gavia stellata. Regular migrant, usually not common.

\section{Family Alcidae.}

6. Ancient Murrelet. Synthliboramphus antiquus. Accidental, one record $(A u k, 1912, \mathrm{pp} .387-$ 8).

7. Mandt's Guillemot (?). Cepphus mandti(?). Accidental, one record, which probably belongs to this form, rather than to Cepphus grylle. 


\section{BIRDS}

8. Brünnich's Murre. Uria lomvia lomvia. Accidental migrant, sometimes common between 1893 and 1908.

9. Razor-billed Auk. Alca torda. Accidental, one record.

\section{Family Stercorarimat.}

10. Parasitic Jaeger. Stercorarius parasiticus. Rare migrant.

Family Larmae.

11. Ivory Gull. Pagophila alba. Accidental, one record.

12. Kittiwake. Rissa tridactyla tridactyla. Accidental migrant.

13. Glaucous Gull. 'Larus hyperboreus. Regular winter resident, rare.

14. Iceland Gull. Larus leucopterus. Accidental, one record.

15. Great Black-backed Gull. Larus marinus. Regular winter resident, not very common.

16. Herring Gull. Larus argentatus. Resident, abundant; does not breed.

17. Ring-billed Gull. Larus delawarensis. Regular migrant, sometimes very common.

18. Laughing Gull. Larus atricilla. Two records; possibly a regular migrant.

19. Bonaparte's Gull. Larus philadelphia. Regular migrant, sometimes abundant. 


\section{NATURAL HISTORY, TORONTO REGION}

20. Caspian Tern. Sterna caspia. Regular migrant, usually not common.

21. Forster's Tern. Sterna forsteri. Two records, possibly a regular migrant.

22. Common Tern. Sterna hirundo. Regular migrant, sometimes common.

23. Black Tern. Hydrochelidon nigra surinamensis. Regular migrant, sometimes common; rare breeder.

\section{Family Procellarimate.}

24. Black-capped Petrel. Aestrelata hasitata. Accidental, one record.

\section{Family Suldoat.}

25. Gannet. Sula bassana. Accidental, two records, one recent ( $A u k, 1913$, p. 225).

Family Phalacrocorvacidae.

26. Cormorant. Phalacrocorax carbo. Accidental, one record.

27. Double-crested Cormorant. Phalacrocorax auritus auritus. Irregular migrant, not common.

\section{Family Pelecantdae.}

28. White Pelican. Pelecanus erythrorhynchos Accidental; one taken $(A u k, 1913$, p. 225$)$; several sight records. 


\section{BIRDS}

Family Aratidae.

29. Merganser. Mergus americanus. Winter resident and common migrant.

30. Red-breasted Merganser. Mergus serrator. Regular migrant, common.

31. Hooded Merganser. Lophodytes cucullatus. Regular migrant, common.

32. Mallard. Anas platyrhynchos. Migrant, not common.

33. Black Duck. Anas rubripes. Regular migrant, common; said to have formerly bred; one recent breeding record.

34. Gadwall. Chaulelasmus streperus. Irregular migrant, rare.

35. Baldpate. Mareca americana. Regular migrant, not common; reported as abundant in Seton's manuscript list of 1884 .

36. Green-winged Teal. Nettion carolinense. Regular migrant; rare, formerly abundant.

37. Blue-winged Teal. Querquedula discors. Regular migrant, not uncommon; formerly much more abundant, probably bred.

38. Shoveller. Spatula clypeata. Migrant, not common.

39. Pintail. Defila acuta. Regular migrant, not uncommon.

40. Wood Duck. Aix sponsa. Regular migrant, not uncommon, 


\section{NATURAL HISTORY, TORONTO REGION}

- 41. Redhead. Marila americana. Regular migrant, common.

42. Canvas-back. Marila valisineria. Regular migrant, not uncommon.

- 43. Scaup Duck. Marila marila. Regular migrant and winter resident, abundants

- 44. Lesser Scaup Duck. Marila affinis. Regular migrant, abundants

45. Ring-necked Duck. Marila collaris. Migrant, not common.

- 46. Golden-eye. Clangula clangula americana. Regular migrant and winter resident, Gbundant.

- 47. Barrow's Golden-eye. Clangula islandica. Accidental, one record.

48. Buffle-head. Charitonetta albeola. Regular migrant, common.

49. Old-squaw. Heralda hyemalis. Regular winter resident, abundants

50. Harlequin Duck. Histrionicus histrionicus. Accidental, at least four records.

51. King Eider. Somateria spectabilis. Winter resident, not very common.

52. Scoter. Oidemia americana. Regular fall migrant, not common.

-53. White-winged Scoter. Oidemia deglandi. Regular migrant, common.

54. Surf Scoter. Oidemia perspicillata. Regular fall migrant, not very common. 


\section{BIRDS}

55. Ruddy Duck. Erismatura jamaicenensis. Regular fall migrant, said to have been formerly very abundant.

56. Snow Goose. Chen hyperboreus hyperboreus. Migrant, very rare (Auk, 1913, p. 226).

57. Blue Goose. Chen caerulescens. Accidental, one definite record.

58. Canada Goose. Branta canadensis canadensis. Regular migrant, formerly common.

59. Hutchins' Goose. Branta canadensis hutchinsi. Accidental, one definite record.

60. Brant, Branta bernicla glaucogastra. Accidental, two records.

61. Whistling Swan. Olor columbianus. Accidental (Auk, 1913, p. 226).

62. Trumpeter Swan. Olor buccinator. No recent records.

\section{Family Ardeidae.}

63. Bittern. Botaurus lentiginosus. Summer resident; abundant migrant, breeds.

64. Least Bittern. Ixobrychus exilis. Common summer resident, breeds.

65. Cory's Least Bittern. Ixobrychus neoxenus. Sixteen specimens have been recorded from here, no recent ones; formerly bred.

66. Great Blue Heron. Ardea herodias herodias. Regular migrant, common.

67. Green Heron. Butorides virescens virescens. Regular migrant, not common. 


\section{NATURAL HISTORY, TORONTO REGION}

68. Black-crowned Night Heron. Nycticorax nycticorax naevius. Regular migrant, not common.

69. Yellow-crowned Night Heron. Nyctanassa violacea. Accidental. One record.

\section{Family Gruidae.}

70. Little Brown Crane (?). Grus canadensis? Accidental; the two Toronto birds probably belong to this species and not to Grus mexicana.

\section{Family Rallidae.}

71. King Rail. Rallus elegans. Irregular migrant, probably accidental.

72. Virginia Rail. Rallus virginianus. Summer resident, common, breeds.

73. Sora. Porzana carolina. Summer resident, common; breeds.

74. Yellow Rail. Coturnicops noveboracensis. Regular fall migrant, rare.

75. Florida Gallinule. Gallinula galeata. Summer resident, common; breeds.

76. Coot. Fulica americana. Regular migrant, common; probably breeds.

\section{Family Phalaropidae.}

77. Red Phalarope. Phalaropus fulicarius. Regnlar fall migrant, rare.

78. Northern Phalarope. Lobipes lobotus. Regular migrant, rare. 


\section{BIRDS}

79. Wilson's Phalarope. Steganopus tricolor. Irregular migrant, very rare.

\section{Family Recurvirostridae.}

80. Avocet. Recurvirostra americana. Accidental, two records.

\section{Family Scolopacidae.}

81. Woodcock. Philohela minor. Regular migrant, not now common; probably breeds.

82. Wilson's Snipe. Gallinago delicata. Regular migrant, not uncommon; rare breeder.

83. Dowitcher. Macrorhamphus griseus griseus. Regular migrant, not common.

84. Long-billed Dowitcher. Macrorhamphus griseus scolopaceus. Accidental, two records referable to this doubtful form.

85. Stilt Sandpiper. Micropalama himantopus. Fall migrant, rare.

86. Knot. Tringa canutus. Regular migrant, not uncommon.

87. Purple Sandpiper. Arquatella maritima maritima. Fall migrant, rare.

88. Pectoral Sandpiper. Pisobia maculata. Fall migrant, sometimes common.

89. White-rumped Sandpiper. Pisobia fuscicollis. Regular migrant, not common.

90. Baird's Sandpiper. Pisobia bairdi. Fall migrant, not uncommon. 


\section{NATURAL HISTORY, TORONTO REGION}

91. Least Sandpiper. Pisobia minutilla. Regular migrant, common.

92. Red-backed Sandpiper. Pelidna alpina sakhalina. Regular migrant, abundant.

93. Curlew Sandpiper. Erolia ferruginea. Accidental, one record.

94. Semipalmated Sandpiper. Ereunetis pusillus. Regular migrant, common.

95. Sanderling. Calidris leucophaea. Regular migrant, abundant.

96. Marbled Godwit. Limosa fedoa. Irregular migrant, very rare.

97. Hudsonian Godwit. Limosa haemastica. Irregular migrant, very rare.

98. Greater Yellow-legs. Totanus melanoleucus. Regular migrant, common.

99. Yellow-legs. Totanus flavipes. Regular migrant, common.

100. Solitary Sandpiper. Helodromas solitarius solitarius. Regular migrant, local and not uncommon.

101. Western Willett. Catoptrophorus semipalmatus inornatus. Irregular migrant, very rare.

102. Ruff. Machetes pugnax. Accidental, one record.

103. Upland Plover. Bartramia longicauda. Migrant, very rare; formerly bred.

104. Buff-breasted Sandpiper. Tryngites subruficollis. Fall migrant, rare. 


\section{BIRDS}

105. Spotted Sandpiper. Actitis macularia. Summer resident, abundant; breeds.

106. Hudsonian Curlew. Numenius hudsonicus. Regular migrant, sometimes abundant.

107. Eskimo Curlew. Numenius borealis. Accidental, two records.

\section{Family Charadritdae.}

108. Black-bellied Plover. Squatarola squatarola. Regular migrant, sometimes common.

109. Golden Plover. Charadrius dominicus dominicus. Fall migrant, not so rare as it was.

110. Killdeer. Oxyechus vociferus. Summer resident, not uncommon; breeds.

111. Semipalmated Plover. Aegialitis semipalmata. Regular migrant, common.

112. Piping Plover. Aegialitis meloda. Summer resident, rare; breeds.

113. Snowy Plover. Aegialitis nivosa. Accidental, two records.

\section{Family Aphrizidae.}

114. Ruddy Turnstone. Arenaria interpres morinella. Regular migrant, common.

\section{Family Odontophoridae.}

115. Bob-white. Colinus virginianus virginianus. Formerly resident and abundant, now exterminated; formerly bred. 


\section{NATURAL HISTORY, TORONTO REGION}

116. Canadian Ruffed Grouse. Bonasa umbellus togata. Resident, becoming very rare; breeds.

\section{Family Coldmbidae.}

117. Passenger Pigeon. Ectopistes migratorius. Extinct, once an abundant migrant; formerly bred.

118. Mourning Dove. Zenaidura macroura carolinensis. Summer resident, not common; breeds.

\section{Family Cathartidae.}

119. Turkey Vulture. Cathartes aura septentrionalis. Accidental, one recent record.

Family Buteonidae.

120. Marsh Hawk. Circus hudsonius. Regular migrant, common, rare summer resident; breeds.

121. Sharp-shinned Hawk. Accipiter velox. Common migrant, rare resident; breeds.

122. Cooper's Hawk. Accipiter cooperi. Rare migrant, rare winter resident.

123. Goshawk. Astur atricapillus atricapillus. Regular fall migrant, sometimes common, rare winter resident.

124. Red-tailed Hawk. Buteo borealis borealis. Common fall migrant; probably breeds.

125. Western Red-tail. Buteo borealis calurus. Accidental, one record.

126. Red-shouldered Hawk. Buteo lineatus lineatus. Common migrant, rare, resident; breeds. 


\section{BIRDS}

127. Swainson's Hawk. Buteo swainsoni. Accidental, five records.

128. Broad-winged Hawk. Buteo platypterus. Regular migrant, common in fall.

129. Rough-legged Hawk. Archibuteo lagopus sancti-johannis. Regular fall migrant, sometimes abundant, uncommon winter resident.

130. Golden Eagle. Aquila shrysaëtos. Accidental, four records.

131. Northern Bald Eagle. Haliceetus leucocephalus alascanus. Migrant, and rare winter resident.

Family Falcovidae.

132. White Gyrfalcon. Falco islandus. Accidental, one record.

133. Duck Hawk. Falco peregrinus anatum. Regular fall migrant, rare.

134. Pigeon Hawk. Falco columbarius columbarius. Regular fall migrant, never very common.

135. Sparrow Hawk. Falco sparverius sparverius. Common migrant, rare summer resident; breeds.

136. Osprey. Pandion hatiaëtus carolinensis. Regular migrant, not common.

\section{Family Aruconidae.}

137. Barn Owl. Aluco pratincola. Accidental, one record.

Family Strigidae.

138. Long-eared $\mathrm{Owl}$. Asio wilsonianus. Common migrant, rare summer resident; breeds. 


\section{NATURAL HISTORY, TORONTO REGION}

139. Short-eared Owl. Asio flammeus. Regular migrant, sometimes abundant.

140. Barred Owl. Strix varia varia. Regular migrant, sometimes common, rather rare winter resident.

141. Great Gray 0wl. Scotiaptex nebulosa nebulosa. Irregular winter migrant, sometimes common.

142. Richardson's Owl. Cryptoglaux funerea richardsoni. Irregular winter migrant, rare.

143. Saw-whet Owl. Cryptoglaux acadica acadica. Regular fall migrant, sometimes common, rare resident; probably breeds.

144. Screech Owl. Otus asio asio. Regular migrant, sometimes common.

145. Great Horned Owl. Bubo virginianus virginianus. Winter resident, usually common, rare resident; breeds.

146. Arctic Horned Owl. Bubo virginianus subarcticus. Rare migrant.

147. Labrador Horned Owl. Bubo virginianus heterocnemis. Rare migrant.

148. Snowy Owl. Nyctea nyctea. Regular winter migrant, sometimes common.

149. Hawk Owl. Surnia ulula caparoch. Irregular winter migrant, rare.

\section{Family Cuculidae.}

150. Yellow-billed Cuckoo. Coccyzus americanus americanus. Summer resident, not very common; breeds. 


\section{BIRDS}

151. Black-billed Cuckoo. Coccyzus erythrophthalmus. Summer resident, fairly common; breeds.

Family Alcedinmae.

152. Belted Kingfisher. Ceryle alcyon. Summer resident, common; breeds.

\section{Family Picidae.}

153. Hairy Woodpecker. Dryobates villosus villosus. Regular migrant, sometimes common, rather rare winter resident.

154. Northern Hairy Woodpecker. Dryobates villosus leucomelas. Winter migrant of recent record (Proc. U.S. Nat. Mus., 1911, p. 604).

155. Downy Woodpecker. Dryobates pubescens medianus. Resident and common migrant; breeds.

156. Arctic Three-toed Woodpecker. Picoides arcticus. Accidental, only a few records.

157. Three-toed Woodpecker. Picoides americanus americanus. Accidental, one record.

158. Yellow-bellied Sapsucker. Sphyrapicus varius varius. Regular migrant, abundant; rare breeder.

159. Northern Pileated Woodpecker. Phloeotomus pileatus abieticola. Accidental, last record in 1882, probably a former resident.

160. Red-headed Woodpecker. Melanerpes erthrocephalus. Summer resident, formerly common; breeds.

161. Red-bellied Woodpecker. Centurus carolinus. Accidental, only a few records. 


\section{NATURAL HISTORY, TORONTO REGION}

162. Northern Flicker. Colaptes auratus luteus. Summer resident, common; breeds, rare winter resident.

\section{Family Caprimdolgidae.}

163. Whip-poor-will. Antrostomus vociferus vociferus. Regular migrant; rare breeder.

164. Nighthawk. Chordeiles virginianus virginianus. Common summer resident; breeds.

Family Micropodidat.

165. Chimney Swift. Chaetura pelagica. Common summer resident; breeds.

\section{Family Trochilidae.}

166. Ruby-throated Hummingbird. Archilochus colubris. Migrant, abundant, rare summer resident; breeds.

\section{Family Trrannidae.}

167. Kingbird. Tyrannus tyrannus. Summer resident, common.

168. Crested Flycatcher. Myiarchus crinitus. Regular migrant, rare summer resident; breeds.

169. Phœbe. Sayornis phoebe. Summer resident, common; breeds.

170. Olive-sided Flycatcher. Nuttallornis borealis. Migrant, only a few records.

171. Wood Pewee. Myiochanes virens. Summer resident, breeds; common migrant. 


\section{BIRDS}

172. Yellow-bellied Flycatcher. Empidonax flaviventris. Regular migrant, usually not abundant.

173. Alder Flycatcher. Empidonax trailli alnorum. Rare migrant.

174. Least Flycatcher. Empidonax minimus. Regular migrant, sometimes abundant; rare breeder.

\section{Family Alaudidat.}

175. Horned Lark. Otocoris alpestris alpestris. Migrant, no recent records.

176. Prairie Horned Lark. Otocoris alpestris praticola. Regular migrant, abundant, rather common resident; breeds.

\section{Family Corvidae.}

177. Blue Jay. Cyanocitta cristata cristata. Resident, sometimes abundant; rare breeder.

178. Canada Jay. Perisoreus canadensis canadensis. Accidental records of two migrations.

179. Northern Raven. Corvus corax principalis. No recent records, probably once a resident.

180. Crow. Corvus brachyrhynchos brachyrhynchos. Resident, abundant; breeds.

181. Bobolink. Dolichonyx oryzivorus. Summer resident; breeds.

182. Cowbird. Molothrus ater ater. Summer resident, common, a parasite.

183. Yellow-headed Blackbird. Xanthocephatus xanthocephalus. Accidental, one record. 


\section{NATURAL HISTORY, TORONTO REGION}

184. Red-winged Blackbird. Agelaius phoeniceus phoeniceus. Summer resident, abundant; breeds.

185. Meadowlark. Sturnella magna magna. Summer resident, common; breeds.

186. Orchard Oriole. Icterus spurius. Summer resident, very rare; breeds.

187. Baltimore Oriole. Icterus galbula. Summer resident, common; breeds.

188. Rusty Blackbird. Euphagus carolinus. Regular migrant, sometimes abundant.

189. Bronzed Grackle. Quiscalus quiscula aeneus. Summer resident, common; breeds.

\section{Family Fringillidae.}

190. Evening Grosbeak. Hesperiphona vespertina vespertina. Irregular winter migrant, occasionally abundant.

191. Pine Grosbeak. Pinicola enucleator leucura. Irregular winter migrant, often abundant.

192. Purple Finch. Carpodacus purpureus purpureus. Resident; breeds, sometimes abundant in winter.

193. Crossbill. Loxia curvirostra minor. Irregular winter resident, sometimes abundant.

194. White-winged Crossbill. Loxia leucoptera. Irregular winter resident, usually rare.

195. Hoary Redpoll. Acanthis hornemanni exilipes. Winter migrant, rare.

196. Redpoll. Acanthis linaria linaria. Irregular winter migrant, often abundant. 


\section{BIRDS}

197. Holbœll's Redpoll. Acanthis linaria holboelli. Accidental winter migrant, three records.

198. Greater Redpoll. Acanthis linaria rostrata. Winter migrant, very rare.

199. Goldfinch. Astragalinus tristis tristis. Resident, common; breeds, often abundant.

200. Pine Siskin. Spinus pinus. Winter resident, sometimes abundant.

201. House Sparrow. Passer domesticus. Introduced, abundant; breeds.

202. Snow Bunting. Plectrophenax nivalis nivalis. Winter migrant, usually abundant.

203. Lapland Longspur. Calcarius lapponicus lapponicus. Irregular winter migrant, not common.

204. Vesper Sparrow. Pocecetes gramineus gramineus. Summer resident, abundant; breeds.

205. Savannah Sparrow. Passerculus sandwichensis savanna. Summer resident, common; breeds.

206. Grasshopper Sparrow. Ammodramus savannarum australis. Accidental, two records.

207. Leconte's Sparrow. Passerherbulus lecontei. Accidental, one record.

208. Nelson's Sparrow. Passerherbulus nelsoni nelsoni. Rare migrant, eleven records.

209. Lark Sparrow. Chondestes grammacus grammacus. Summer resident, very rare; breeds.

210. White-crowned Sparrow. Zonotrichia leucophrys leucophrys. Regular migrant, usually common. 


\section{NATURAL HISTORY, TORONTO REGION}

211. 'White-throated Sparrow. Zonotrichia albicollis. Regular migrant, abundant, rare summer resident; breeds.

212. Tree Sparrow. Spizella monticola monticola. Winter resident, sometimes abundant.

213. Chipping Sparrow. Spizella passerina passerina. Summer resident, abundant; breeds.

214. Field Sparrow. Spizella pusilla pusilla. Summer resident, abundant, migrant; breeds.

215. Slate-colored Junco. Junco hyemalis hyemalis. Regular migrant, abundant, irregular winter resident; rare breeder.

216. Song Sparrow. Melospiza melodia melodia. Summer resident, abundant; breeds; occasional winter resident.

217. Lincoln's Sparrow. Melospiza lincolni lincolni. Regular migrant, not common.

218. Swamp Sparrow. Melospiza georgiana. Summer resident, common; breeds;

219. Fox Sparrow. Passerella iliaca iliaca. Regular migrant, not common.

220. Towhee. Pipilo erythrophthalmus erythrophthalmus. Summer resident; breeds; common migrant.

221. Cardinal. Cardinalis cardinalis cardinalis. Accidental, very few records.

222. Rose-breasted Grosbeak. Zamelodia ludoviciana. Regular migrant, fairly common.

223. Indigo Bunting. Passerina cyanea. Regular migrant, not very common summer resident; breeds. 


\section{BIRDS}

\section{Family Taragrioae.}

224. Scarlet Tanager. Piranga erythromelas. Regular migrant, sometimes common.

225. Summer Tanager. Piranga rubra rubra. Accidental, one record.

\section{Family Hirundixidae.}

226. Purple Martin. Progne subis subis. Summer resident; breeds, increasing in numbers.

227. Cliff Swallow. Petrochelidon lunifrons lunifrons. Summer resident, formerly common and bred, now a rather rare migrant.

228. Barn Swallow. Hirundo erythrogastra. Regular summer resident, common; breeds.

229. Tree Swallow. Iridoprocne bicolor. Regular summer resident, common; breeds.

230. Bank Swallow. Riparia riparia. Regular summer resident, common; breeds.

231. Rough-winged Swallow. Stelgidopteryx serripennis. Rare summer resident; breeds.

\section{Family Bombrcillidae.}

232. Bohemian Waxwing. Bombycilla garrula. Irregular winter resident, rare.

233. Cedar Waxwing. Bombycilla cedrorum. Resident, irregular in winter, often abundant; breeds.

$$
\text { Family Lanidate. }
$$

234. Northern Shrike. Lanius borealis. Rare winter resident. 


\section{TATURAL HISTORY, TORONTO REGION}

235. Migrant Shrike. Lanius ludovicianus migrans. Regular summer resident, not common; breeds.

Family Vrreonidae.

236. Red-eyed Vireo. Vireosylva olivacea. Regular summer resident, common, breeds.

237. Philadelphia Vireo. Vireosylva philadelphica. Regular migrant, not very common.

238. Warbling Vireo. Vireosylva gilva gilva. Regular migrant, not common.

239. Yellow-throated Vireo. Lanivireo flavifrons. Regular migrant, rare.

240. Blue-headed Vireo. Lanivireo solitarius solitarius. Regular migrant, common.

\section{Family Мxiotiltidae.}

241. Black and White Warbler. Mniotilta varia. Regular migrant, abundant, rare summer resident; breeds.

242. Nashville Warbler. Vermivora rubricapilla rubricapilla. Regular migrant, abundant.

243. Orange-crowned Warbler. Vermivora celata celata. Regular migrant, always rare.

244. Tennessee Warbler. Termivora peregrina. Regular migrant, rare.

245. Northern Parula Warbler. Compsothlypis americana usneae. Regular migrant, abundant.

246. Cape May Warbler. Dendroica tigrina. Regular migrant, sometimes fairly common. 
247. Yellow Warbler. Dendroica aestiva aestiva. Regular summer resident, abundant; breeds.

248. Black-throated Blue Warbler. Dendroica caerulescens caerulescens. Regular migrant, abundant.

249. Myrtle Warbler. Dendroica coronata. Regular migrant, not usually common in spring, abundant in autumn.

250. Magnolia Warbler. Dendroica magnotia. Regular migrant, abundant.

251. Cerulean Warbler. Dendroica cerulea. Spring migrant, only a few records.

252. Chestnut-sided Warbler. Dendroica pensylvanica. Regular migrant, abundant; uncommon summer resident, probably breeds.

253. Bay-breasted Warbler. Dendroica castanea. Regular spring migrant, not very common, very few fall records.

254. Black-poll Warbler. Dendroica striata. Regular migrant, usually not very common.

255. Blackburnian Warbler. Dendroica fusca. Regular migrant, common, sometimes abundant.

256. Black-throated Green Warbler. Dendroica virens. Regular migrant, abundant.

257. Kirtland's Warbler. Dendroica kirtlandi. Accidental, one record.

258. Pine Warbler. Dendroica vigorsi. Regular migrant, usually not common.

259. Palm Warbler. Dendroica palmarum palmarum. Regular migrant, usually not common. 


\section{NATURAL HISTORY, TORONTO REGION}

260. Prairie Warbler. Dendroica discolor. Accidental, two records.

261. Oven-bird. Seiurus aurocapillus. Regular migrant, abundant; a not very common summer resident; breeds.

262. Water Thrush. Seiurus noveboracensis noveboracensis. Regular migrant, usually not very common.

263. Grinnell's Water-Thrush. Seiurus noveboracensis notabilis. Birds referable to this form occur with the preceding ( $A u k, 1908$, p. 487).

264. Louisiana Water-Thrush. Seiurus motacilla. Accidental, two records.

265. Connecticut Warbler. Oporornis agilis. Regular migrant, not common.

266. Mourning Warbler. Oporornis philadelphia. Regular migrant, not uncommon; rare summer resident; breeds.

267. Maryland Yellow-throat. Geothlypis trichas trichas. Regular migrant, common; rare summer resident.

268. Wilson's Warbler. Wilsonia pusilla pusilla. Regular migrant, common.

269. Canada Warbler. Wilsonia canadensis. Regular migrant, common, probably a rare summer resident.

270. Redstart. Setophaga ruticilla. Regular migrant, abundant; fairly common summer resident; breeds. 


\section{BIRDS}

\section{Family Motacillidae.}

271. Pipit. Anthus rubescens. Regular migrant, often common in fall.

$$
\text { Family Mimidane. }
$$

272. Catbird. Dumetella carolinensis. Regular summer resident, common; breeds.

273. Brown Thrasher. Toxostoma rufum. Regular summer resident; breeds.

\section{Family Troglodytidae.}

274. House Wren. Troglodytes aëdon aëdon. Regular migrant and fairly common summer resident.

275. Winter Wren. Nannus hiemalis hiemalis. Regular migrant, common; rare summer resident; breeds.

276. Short-billed Marsh Wren. Cistothorus stellaris. Two records.

277. Long-billed Marsh Wren. Telmatodytes palustris palustris. Common summer resident; breeds.

Family Certhirdae.

278. Brown Creeper. Certhia familiaris americana. Regular migrant, common; probably a rare summer resident.

\section{Family Sittidae.}

279. White-breasted Nuthatch. Sitta carolinensis carolinensis. Common migrant and winter resident. 


\section{NATCRAL HISTORY, TORONTO REGION}

280. Red-breasted Nuthatch. Sitta canadensis. Common migrant and a not uncommon winter resident.

Family Paridae.

281. Chickadee. Penthestes atricapillus atricapillus. Resident, common; breeds.

282. Hudsonian Chickadee. Penthestes hudsonicus hudsonicus. Accidental, one record.

Family Sruvitdae.

283. Golden-crowned Kinglet. Regulus satrapa satrapa. Regular migrant, abundant; rare winter resident.

284. Ruby-crowned Kinglet. Regulus calendula calendula. regular migrant, abundant.

285. Blue-gray Gnatcatcher. Polioptila caerulea caerulea. Three records.

\section{Family Turdidae.}

286. Wood Thrush. Hylocichla mustelina. Regular migrant, not common, rare summer resident; breeds.

287. Veery. Hylocichla fuscescens fuscescens. Regular migrant, abundant; fairly common summer resident; breeds.

288. Gray-cheeked Thrush. Hylocichla aliciae aliciae. Regular migrant, rare in spring, not uncommon in fall. 


\section{BIRDS}

289. Olive-backed Thrush. Hylocichla ustulata swainsoni. Regular migrant, abundant.

290. Hermit Thrush. Hylocichla guttata pallasi. Regular migrant, abundant; probably a rare summer resident.

291. Robin. Planesticus migratorius migratorius. Summer resident, abundant; breeds; irregular winter resident.

292. Bluebird. Sialia sialis sialis. Summer resident, abundant; breeds.

\section{REFERENCES.}

R. Ridgway. The Birds of North and Middle America. Bull. U.S. Nat. Museum, No. 50. 1901-1911.

R. Ridgway. A Manual of North American Birds. Philadelphia. 1887.

F. M. Chapman. Handbook of the Birds of Eastern North America. New York and London. 1912.

T. McIlwraith. The Birds of Ontario. William Briggs, Toronto, 1894. 


\section{GHAPTER XVII.}

\section{REPTILES.}

\section{Вy}

\section{J. B. WILLIAMS, F.Z.S.}

Out of about thirty Reptiles, that are found in the Province of Ontario, only eleven occur in the neighbourhood of Toronto.

Of these only two are turtles-the small Mud Turtle, and the large Snapping Turtle.

With a large marshy area, like Ashbridge Bay, close to the city, one would have expected a greater variety; but Toronto never seems to have been very rich in reptile forms. The Blue-tailed Lizard, which occurs north-east of the city at Peterborough, and north-west around the Georgian Bay, has never been found here; and we have no poisonous snakes in this district. Rattlesnakes were, formerly, plentiful in the country from Hamilton to Niagara, and a few still linger in the Niagara glens, and they are also found at the Georgian Bay; but, like the lizard, they seem to prefer rocky districts, and there is no record of their ever occurring near Toronto.

Nine snakes are found in this neighbourhood; four of these, viz., the Red-bellied, Dekay's Brown, Grass, and Ring-necked, are small snakes varying from a foot to eighteen inches in length; the other 


\section{REPTILES}

five, viz., the Riband, Garter, Water, Milk, and Hog-nosed, are larger ones, averaging about three feet in length. They are all quite harmless, if left alone, and several of them are really useful. The Grass Snake is very fond of cut-worm caterpillars that do so much injury to lawns and gardens, and the Milk Snake feeds very largely on field mice and volestwo of the farmer's great enemizs.

\section{Order OpHIDIA.}

Red-bellied Snake, Storeria occipitomaculata, Baird \& Gir. Not very common; are said to feed on soft-bodied insects.

DeKay's Brown Snake, Storeria dekayi, Baird \& Gir. The commonest of the small snakes; feeds on earthworms and insects; viviparous and produces from twelve to twenty-four young at a time; often found on the waste land at the sides of railroads.

Riband Snake, Eutainia saurita, Baird \& Gir. A very graceful and beautiful species; not very common; it used to be found at the Woodbine and Balmy Beach; feeds on small frogs and earthworms.

Garter Snake, Eutainia sirtalis, Baird \& Gir. The commonest of the large snakes; frequents woods and grassy fields; feeds on frogs, toads and earthworms; viviparous, having as many as twenty young at a time.

Water Snake, Tropidonotus sipedon, Holbr. Fairly common about streams and ponds; feeds on 


\section{NATLRAL HISTORY, TORONTO REGION}

fish and frogs; viviparous, and very prolific, sometimes producing forty young at a time.

Grass Snake, Liopeltis vernalis, Jan. Fairly common, and well worth protecting, for its beauty, as well as for its usefulness. Feeds largely on caterpillars.

Ring-necked Snake, Diadophis punctatus, Baird \& Gir. Rather rare; said to feed largely on insects.

Milk Snake, Ophibolus doliatus, Baird \& Gir. Fairly common, especially on the west side of the city; feeds largely on field mice and voles, which it crushes to death between the folds of the body; in captivity they will sometimes eat smaller snakes that are kept with them, and they hare a curious habit of ribrating the tip of the tail when they are excited, just as a rattlesnake does.

Hog-nosed Snake, or Blowing Adder, Heterodon platyrhinus, Latreille. T'sed to be fairly common at High Park, but is rarer now; feeds on frogs and toads, but seems to prefer the toads. When annoyed it hisses and spreads the skin of the head and neck in a very threatening way, but it is not at all venomous; and, in captivity, soon becomes quite tame.

\section{Order Testedinata.}

Snapping Turtle, Chelydra serpentina, Schw. A large and roracious reptile; quite common at the Island. They are credited with the destruction of many young ducks and other waterfowl. In cap- 


\section{REPTILES}

tivity they will feed on small fish, raw meat, or earthworms.

Mud Turtle, or Painted Turtle, Chrysemys picta, Ag. A very common and prettily marked species; often seen sunning themselves on logs. In captivity they will feed on small fish, raw meat, earthworms, and insects.

\section{REFERENCES.}

Cope, E. D. The Crocodilians, Lizards and Snakes of North America. Rep. U. S. Natl. Museum for 1898. Washington, 1900.

Jordan, D. S. Manual of the Vertebrates of the Northern United States. Chicago, 1894. 


\section{GHAPTER XVIII.}

\section{AMPHIBIA. \\ B y \\ W. H. PIERSOL, B.A., M.B.}

THE following list contains all the Amphibia that have been reported from the neighbourhood of Toronto or are known by the author to occur in that region. A few additional species, that may occur but have not yet been reported, are mentioned at the end of the list.

\section{URODELA.}

Mud-puppy, Necturus maculosus, Rafinesque. In quiet waters, at depths of 2-20 feet; Don and Humber rivers, Island lagoons, wharves. Spawns in quiet waters under stones, etc.; at depths of 3-12 feet. May 1st-June 5th. No metamorphosis.

Spotted Salamander, Ambystoma punctatum, Linn. On all sides of the city in woods, preferably dark woods with light undergrowth and little grass. At the breeding season, near pools, under any object. that will give shelter, at other seasons in or under decaying logs and stumps, sometimes under stones. Spawns in pools, eggs in large masses attached to grass or twigs. April 1-30, usually April 10-17. Metamorphosis in September-October of same year. 


\section{AMPHIBIA}

Salamander, Ambystoma jeffersonianum, Green. Localities as for Ambystoma punctatum. Not common except in woods to the east of Toronto on Scarborough Heights. Spawns in pools, small masses of eggs being attached in rows to slender branches or to weeds. Narch 24-April 20, usually April 1-10. Metamorphosis in September-October of same year.

Black Newt, Desmoganthus nigra, Green. Only known as from Toronto by a specimen so labelled in the Biological museum; no more definite locality is mentioned. Usually in or near clear, cald spring's or brooks in rocky localities.

Red-backed Salamander, Plethodon cinereus, Green. This includes the varieties Plethodon cinereus cinereus and Plethodon cinereus erythronotus (Cope), intermediates, and also individuals with more red marking than is typical. It occurs on all sides of the city. Remains under shelter by day. Damp woods with considerable undergrowth are preferred, but occasionally specimens are found in drier localities, even in open fields under stones. Spawning by choice within the cracks in decaying logs and stumps, but in default of such under stones. A cluster of 3-12 eggs attended by the female. June 15July 4. No aquatic stage. Metamorphosis takes place in August-September of the same year.

Salamander, Hemidactylium scutatum, Schlegel. One specimen reported from the Humber Valley. Habits, etc., so far as known, are similar to those of Plethodon. 


\section{NATURAL HISTORY, TORONTO REGION}

Newt, Diemyctylus viridescens, Rafinesque. This includes the terrestrial variety, miniatus, Raf. The species occurs on all sides of the city, in pools, bays of the larger bodies of water, (e.g., Howard Lake and Island Lagoons), and in the quieter portions of streams where there is considerable vegetation growing in water. The eggs are deposited singly on water plants, almost daily for some weeks, April 15June 15, and the metamorphosis takes place in September of the same year. The terrestrial stage lasts one or more years; it is first interrupted by the return to water in breeding season, and as age increases this aquatic phase is lengthened and at last becomes permanent.

\section{AnURa.}

Common Toad, Bufo lentiginosus, var. americanus, Cope. Occurs everywhere, in woods, along hedges and fences, in gardens. The spawn is in coiled strings, submerged at the edges of quiet waters. April-July. Tadpole black. Metamorphosis occurs after about eight weeks.

Swamp Tree Frog, Chorophilus triseriatus, Wied. Low and marshy land, Humber and Don valleys. Spawn in masses containing 20 to 100 eggs, submerged on grasses and twigs in pools in open meadows, ditches, etc. April 1-20. Tadpole black and sluggish. Metamorphosis occurs in ten to twelve weeks. 


\section{AMPHIBIA}

Common Tree Frog, Hyla versicolor, LeConte. Occurs in woods containing bushes and low trees on all sides of the city. Spawns among grasses at edges of pools, eggs in small masses close to surface of water, or floating. May 20-July 1. The tadpole has a very considerable metallic lustre and shows very rapid morements. The metamorphosis takes place in about seven weeks.

Spring Peeper, Hyla pickeringii, Holbrook. Found only to west of city, though it probably occurs on the north and east as well. In woods containing bushes and low trees. The eggs are attached in very small groups to grasses at the margin of pools, close to surface of water. April 10-May 1. The tadpole has but very little dark pigment. The metamorphosis occurs in about eight weeks, while the tail is yet long.

Leopard Frog, Rana pipiens, Shreber. In the neighbourhood of streams and pools, or even at considerable distances from water in long grass. On all sides of the city. Spawns in shallow parts of pools, egg masses submerged. April 15-May 20. Tadpole very dark. Metamorphosis takes place in about ten weeks.

Pickerel Frog, Rana palustris, Leconte. Near the edges of marshes and brooks, where the water may be reached by a few very long leaps. Has been found only along streams to the west of the city, but probably occurs to the north and east as well. 


\section{NATURAL HISTORY, TORONTO REGION}

Spawns in shallow, quiet waters, the egg masses submerged, April 25-May 15. Tadpole quite light in colour. Metamorphosis takes place in ten to twelve weeks.

Wood Frog, Rana sylvatica, LeConte. On all sides of the city, in moist woods with considerable undergrowth. Spawns on the bottom of pools, at a depth of about one foot. March 30-April 30. Tadpole dark gray. Metamorphosis takes place in about ten weeks.

Green Frog, Rana clamitans, Latreille. On all sides of the city, by marshy margins of bays, pools, rivers, or small streams. The spawn is spread on the surface of the water amongst weeds. May 25August 10. Tadpole light coloured. Metamorphosis occurs only after one or two years.

Bullfrog, Rana catesbiana, Shaw. In the marshy margins of bays, rivers or large ponds, in the water or on a lily-leaf. The spawn is spread on the surface of the water, amongst weeds. June 20-July 25. Tadpole brownish green, large; tail very long. Metamorphosis occurs only after one or two years.

The following species may occur near Toronto, but they have not yet been reported nor have they come to the writer's notice:

Cricket Frog, Acris gryllus, LeConte.

Northern Frog, Rana septentrionalis.

Cambridge Frog, Rana cantabrigensis, Baird. 


\section{AMPHIBIA}

\section{REFERENCE}

Cope, E. D. The Batrachia of North America. Bull. U. S. Nat. Mus. No. 34. 1889.

Dickerson, Mary C. The Frog Book (Doubleday, Page \& Co.). 1906.

Wright, A. H. The Anura of Ithaca, N.Y.-A Key to Their Eggs. Biol. Bull., vol. 18, No. 2. 1910.

Cochran, M. E. The Biology of the Red-backed Salamander. Biol. Bull., vol. 20, No. 6, 1911.

Eycleshymer, A. C. The Habits of Necturus maculosus. Amer. Nat. vol. 40, p. 123. 1906. Gage, S. H. The Life History of the Vermilionspotted Newt. Amer. Nat., vol. 25, p. 1084. 1891.

Garnier, R. A New Species of Menobranchus. Proc. Can. Inst., vol. 5, p. 218, 1887. Hodgins, J. G. Proteus of the Lakes. Can. Jour., vol. 1, p. 19.1856.

Jordan, E. O. Habits and Derelopment of the Newt (Diemyctylus viridiscens). Jour. of Morphology, rol. 8, 1893.

Jordan, E. O. The Spermatophores of Diemyctylus. Jour. Morph., vol. 5, p. 263. 1891.

Montgomery, H. Some Observations on the Menobranchus maculatus. Can. Nat. and Geol., N.S., vol. 9, p. 160. 1881.

Nicholson, H. A. Contributions to a Fauna Canadensis. Can. Jour., vol. 13, p. 493. 1873. 
Piersol, W. H. Spawn and Larva of Ambystoma jeffersonianum. Amer. Nat., vol. 44, p. 732. 1910.

Piersol, W. H. The Habits and Larval State of Plethodon cinereus erythronotus. Trans. Can. Inst., vol. 8, part 4. 1909.

Reed, H. D. A Note on the Coloration of Plethodon cinereus. Amer. Nat., vol. 42, p. 460, 1908. Smith, B. G. The Nests and Larrae of Necturus. Biol. Bull., vol. 20, No. 4. 1911.

Smith, B. G. The Structure of the Spermatophores of Ambystoma punctatum. Biol. Bull., vol. 18, No. 4, 1910.

Smith, B. G. Notes on the Natural History of Ambystoma jeffersonianum. Ambystoma punctatum, and Ambrstoma tigrinum. Bull. Wiscon. Nat. Hist. Soc., vol. 9, Nos. 1-2. 1911.

Wright, A. H. Notes on the Breeding Habits of Ambystoma punctatum. Biol. Bull., vol. 14, No. 4. 1908.

Wright, A. H., and Allen, A. A. The Early Breeding Habits of Ambystoma punctatum. Amer. Nat., vol. 43, p. 687. 1909.

Wilder, H. H. Desmognathus fusca and Spelerpes bilineatus. Amer. Nat., vol. 33, p. 231. 1899.

Wilder, I. W. The Life History of Desmognathus fusca. Biol. Bull., vol. 24, Nos. 4 and 5. 1913. 


\section{CHAPTER XIX.}

F I S H ES.

By

C. W. NASH.

THE following list includes all the fishes found within a radius of ten or twelve miles from the city of Toronto of which I have authentic records.

\section{MARSIPOBRANCHII. (The Lampreys.)}

Petromyzidae.

1. Silver Lamprey. Lamper Eel. Icthyomyzon concolor (Kirtland).-The Silver Lamprey is abundant in Lake Ontario, usually in deep water, but it runs up the small streams to spawn in the spring. It is a most destructive parasite on the large commercial fishes, fixing itself to their bodies by means of its suctorial disk and causing deep ulcerated wounds at the point of attachment, which very frequently result in death. When spawning they form nests in the bed of the stream among cobble-stones and pebbles; in these the eggs are deposited, after which the parent fish all die. After emerging from the eggs the larvae burrow in the mud or sand near the margin of the stream and there remain in the larval condition, blind and toothless for a long period, 


\section{NATURAL HISTORY, TORONTO REGION}

sometimes until they have attained a length of eight inches.

\section{GANOIDEI. (Ganoid Fishes.)}

Acipexseridat.

2. Lake Sturgeon. Rock Sturgeon. Acipenser rubicundus (Lesueur).- The fishermen make a distinction between the young and the old of this species, calling the former Rock Sturgeon and the older fish Lake Sturgeon. There is, howerer, but one Sturgeon in our waters; the difference in the size and shape of the snout and in the number and derelopment of the spines between the immature fish and the adult is sometimes very great, hence the idea that two species are found. The Lake Sturgeon is found in Lake Ontario, but rarely near Toronto. It is a food fish of considerable commercial importance, its flesh being used either fresh or dried and smoked. From its roe the delicacy known as caviare is made. This fish attains a large size, specimens six feet in length and weighing one hundred pounds or more being not uncommon. The spawning season extends from the end of May to the beginning of July, during which period the fish run from the lakes up the rivers for a considerable distance for the purpose of depositing their ova.

\section{Aumdate. (The Bowfins.)}

3. Dogfish. Bowfin. Mudfish. Amia calva (Linn.).-This fish is found in the weedy waters of 


\section{FISHES}

the bays and rivers in the vicinity of Toronto. It is one of the most voracious of our fishes, feeding upon all forms of small fry and insects, and where abundant is very destructive to the more valuable forms of fish life. Its flesh is said to be soft, nauseous and quite uneatable. In May and June the Dogfish resort to weedy bays and marshes, where they spawn, the parent fish remaining with the eggs until they are hatched, and afterwards protecting the roung for some time. The female is larger than the male, sometimes reaching a length of twenty-four inches, while the male rarely exceeds eighteen.

\section{TELEOSTEI. (The Bony Fishes.) \\ ORDER NEMATOGNATHI. (Catfishes.) Siluridae. (Catfishes.)}

4. Common Catfish. Bullhead. Ameiurus nebulosus (Lesueur). This species reaches a maximum length of about eighteen inches and a weight of four pounds; the average of those taken in our waters is, however, much less. It is the common Catfish of the Province, occurring abundantly in all quiet streams, ponds and bays, especially in those having a mud bottom. Early in June. when about to spawn, the Catfishes select a spot in quiet, shallow water near aquatic weeds, and there they make a nest, from eight inches to one foot in diameter, by clearing out a slight depression in the mud or sand. In this nest about two thousand eggs are deposited, orer 


\section{NATURAL HISTORY, TORONTO REGION}

which the parents keep guard, the male being most assiduous in the work of protection. In about a week the eggs are hatched, and the young, which look very like little black tadpoles, follow the parent fish along the shores until nearly the middle of July, when they are left to shift for themselves; after this the fry soon scatter and disappear into deep weedy water. They grow rapidly, and under favorable circumstances are said to attain maturity in three years. The Catfish is an omnivorous feeder, nothing in the shape of animal food being beneath its notice, nor is it particular where it obtains its food, for I have taken it at all depths, from the surface of the water to the bottom, though its general habit is to grub about on the mud, seeking for what it may devour. As an article of food this fish does not rank in the first class in the estimation of most people; there are others, however, who prefer it to any of the so-called "coarse fish," while to the small boy who goes fishing it is a somrce of endless delight and a joy forever.

5. Stone Catfish. Noturus flavus (Rafinesque). This species is found in the larger streams falling into Lake Ontario, but is not common. It is an unpleasant fish to handle because of the painful wounds produced by its pectoral spines. There is a minute pore at the base of the pectoral spine which is the ontlet of a noxious fluid secreted by a poison gland. When this poison is discharged into a wound it causes a very painful sore. 


\section{FISHES}

\section{ORDER PLECTOSPONDYLI. (Carplike Fishes.)}

Catostomidae. (The Suckers.)

6. Drum. Lake Carp. Carpiodes thompsoni (Agassiz).-Occasionally taken by the gill-net fishermen in Lake Ontario. It attains a weight of five or six pounds, but is not valued as a food fish.

7. Northern Sucker. Long-nosed Sucker. Catostomus catostomus (Forster).-Occasionally taken in Lake Ontario.

8. Common Sucker. White Sucker. Catostomus commersonii (Lacépède). - This is the most abundant of all the Suckers in Ontario waters, and the most generally distributed. It is found in lakes, rivers and even in land-locked marshes and ponds. It spawns in early spring, soon after the ice goes out, and then forces its way up the flooded streams and through the swiftest rapids to reach the spawning beds. At this time vast numbers are speared and netted by fish-hungry people in the rural districts, for at this season its flesh is eatable, though coarse and full of bones. Commercially it is of very little value, but as it affords food for Bass, Lake Trout, and all other predaceous and voracious fishes, it is of considerable economic importance. Its food consists largely of soft-bodied insects and the smaller crustaceans, and it will readily take worm bait. The largest I have ever seen would weigh from three to 


\section{NATURAL HISTORY, TORONTO REGION}

four pounds, but they were exceptional; from one and a half to two being about the average size of the spring run of Suckers.

9. Common Mullet. Red-horse. MLoxostoma aureolum (Lesueur).-This is the handsomest and best of all the Sucker family. It was formerly an abundant spring visitor to the Humber and Don Rivers, but owing to persistent netting during the spawning season it is now very seldom seen. In the early spring, as soon as the ice moves out, Mullet run up the streams to spawn, forcing their way through the swiftest torrents in order to reach the gravelly beds, upon which the ova are deposited. After spawning they retire to deep water. While in the streams they will readily take worm bait, and as they frequently attain a weight of four or five pounds they afford good sport in the waters they frequent.

\section{Crprinidae. (The Carps.)}

10. Creek Chub. Horned Dace. Semotilus atromaculatus (Mitchill).-This species sometimes attains a length of twelve inches; it is very abundant and generally distributed in all the streams of this vicinity. As a food fish it does not take high rank, though it affords a great deal of sport for rural schoolboys. It spawns in early summer on the stony shallows in the streams it frequents.

11. Red-sided Shiner. Leuciscus elongatus (Kirtland).-This beautiful little fish is found in most of the streams having a muddy bottom. 
12. Butterfish. Golden Shiner. Abramis crysoleucas (Mitchill).-Common in the quiet, weedy waters of Toronto and Ashbridge's Bay. Its flesh is edible, but soft and weedy-flavored. Spawns in early summer.

13. Shiner. Redfin. Dace. Notropis cornutus (Mitchill).- This handsome fish is abundant in all streams of any size, particularly so in those where rapids alternate with deep pools and eddies. It spawns in early summer on stony shallows. As a food fish it is of no value, its flesh being soft and tasteless, but it is unexcelled as bait for Maskinonge, Bass, etc.

14. Notropis atherinoides (Rafinesque).-

15. Long-nosed Dace. Niagara Gudgeon. Rhinichthys cataractae (Cuvier and Valenciennes). Abundant in the rapid streams.

16. Black-nosed Dace. Rhinichthys atronasus (Mitchill).-Very common in all streams.

17. Lake Chub. Couesius plumbeus (Agassiz). -Occurs in Lake Ontario, but is not common in this locality.

18. Carp. Cyprinus carpio (Linnaeus) (Introduced).-There are three varieties of this species, the German or Scale Carp, the Mirror Carp, and the Leather Carp, the distinction between them being based upon the scale arrangement. The Leather Carp is nearly without scales. The Mirror has a few scales of unequal size, irregularly placed; while the German variety has the body completely covered 


\section{NATURAL HISTORY, TORONTO REGION}

with scales, this last being the most abundant form in our waters. No greater mistake was ever made than the introduction of this fish into North American waters. In England, where it is well known, it was considered about the most worthless fish they had, and one of the most difficult to get rid of, where once it had become established. On some parts of the continent of Europe, however, where good fish are scarce, the Carp was cultivated and fed in ponds with care, and, probably because the people knew no better, it was more appreciated. In this country, where fish of the highest quality should be obtainable by every one, there is no place for the Carp. DeKay states that it was first introduced into New York waters in 1831 . In 1870 it was taken to California, and in 1877 the United States Fishery Commissioners imported a considerable number and propagated them only too successfully. Since then they have spread into all accessible waters and have become an unbearable nuisance wherever found, for not only are they damaging our fisheries, but also, by reason of their destruction of the wild rice beds, they are causing the wild fowl to avoid the feeding grounds to which they formerly resorted during the autumn flight. The food of Carp consists principally of insects and vegetable matter, preferably, perhaps, of the seeds, young shoots and tender roots of aquatic plants; when feeding it constantly grubs up the bottom, thereby stirring the mud and keeping the water in such a dirty condition that none of our 


\section{FISHES}

valuable fish will remain in it. The spawning season in our waters commences in June and seems to last till August. The fish are very prolific, make rapid growth, and attain a large size, specimens weighing over twenty pounds having frequently been taken in American waters, while in Europe they have been known to reach ninety pounds.

\section{ORDER APODES. (The Eels.)}

Anguillidae. (The True Eels.)

19. American Eel. Anguilla chrysypa (Rafinesque).-Common in Lake Ontario and all waters falling into it. Until recently the reproduction of the Eel has been involved in mystery, but the careful investigations of competent observers have resulted in showing that the Eel spawns in salt water, usually on mud banks off the mouths of rivers, to which they resort in late autumn. When the young Eels are from two to three inches long they ascend the rivers in vast numbers, travelling continually until they meet some obstacle which cannot be overcome. Professor Baird has estimated "that in the summer one may see hundreds of waggon loads of young Eels at the foot of Niagara Falls, crawling over the rocks and squirming in the seething waters." Where the obstruction to their passage permits it, the fish will leave the water and travel through wet grass in order to continue their journey. As a food fish Eels are 
justly esteemed, and in the markets they always sell for a high price.

\section{ORDER ISOSPONDYLI. (The Isospondylous Fishes.)}

\section{Hiodontidae. (The Moon-eyes.)}

20. Mooneye. Hiodon tergisus (Lesueur).-Occasional in Lake Ontario and sometimes strays into Toronto Bay, but is rare in this vicinity. It is a very handsome and good game fish, taking bait very readily, but its flesh is of no value as food.

\section{Dorosomidae. (Gizzard Shads.)}

21. Gizzard Shad. Dorosoma cepedianum (Lesueur).-Taken in Lake Ontario, but very rare. It is a handsome species, but of no value for food.

\section{Clupeidae. (The Herrings.)}

22. Gold Shad. Sawbelly. Pomolobus chrysochloris (Rafinesque).- - Has been occasionally taken in Lake Ontario.

23. Gaspereau Alewife. Pomolobus pseudoharengus (Vilson).- This fish is said to have been introduced into Lake Ontario in 1873 by mistake, the intention having been to stock the water with shad. Whether this is correct or not, the Gasperean is now firmly established here, and in spite of the vast numbers which die every summer it seems to be increas- 


\section{EISHES}

ing. From early in March until early in November they are to be found near the shores of Lake Ontario, but are at the height of their abundance during June and July, and it is during these months that the great mortality takes place, millions of dead fish being cast up on the shore, and the surface of the water being literally strewed with the dead and dying. Where they go in the cold months of winter is uncertain, probably only into the deep water of the lake, though it is possible that they may work their way down to the Gulf of St. Lawrence. They are eatable, but being small and bony are not much appreciated.

\section{Salironidae. (The Salmons.)}

24. Frost-fish. Round Whitefish. Coregonus quadrilateralis (Richardson)-Common in Lake Ontario and highly esteemed as a food fish. It spawns in October and November, visiting the shallow parts of lakes and sandbars for that purpose.

25. Common Whitefish. Coregonus clupeiformis (Mitchill).-Formerly very abundant in Lake Ontario, but now scarce near Toronto. Although this is one of the most valuable of our commercial fish, its habits are not yet fully understood; undoubtedly they vary much according to locality; the depth of water, currents or their absence, and climatic conditions all having some influence upon the movements of the fish in search of food, and upon the time and place of spawning. In Lake Ontario there is a movement of the Whitefish in early summer from the 


\section{NATURAL HISTORY, TORONTO REGION.}

deep water into shoal water near the shore; towards midsummer they retreat to the deep and cold parts of the lake, where they spend most of their time. In the autumn they again move in towards the shore, seeking their spawning grounds; these are chiefly. rocky reefs and shoals, composed of what is known as honeycomb rock. It is said that gravelly and sandy shoals are sometimes resorted to for spawning purposes, but this is doubtful. Spawning takes place in October and Norember, and may possibly be extended by some individuals, or under exceptional circumstances, into December; both the time of spawning and of incubation depend largely upon the temperature. The autumn movement commences in September, but does not become general until October; the fish then continue to run in greater or less numbers until the spawning is ended, when they again retire to deep water for the winter. It is a curious fact that even during the spawning season a large number of Whitefish are always to be found in the deep water, but there is no evidence that they ever spawn there.

26. Cisco. Lake Herring. Argyrosomus artedi (Lesueur).-The Cisco was formerly common in Lake Ontario. Of late years, however, it has not been taken there in any quantity. Its spawning season is in November and early December.

27. Long-jaw Herring. Lake Herring. Argyrosomus prognathus (H. M. Smith).- This fish may readily be distinguished from any other Whitefish found 


\section{FISHES}

in the Great Lakes by the general form of its body, together with the very long lower jaw. There is much difference of opinion among fishermen as to the spawning time of the Long-jaw, which seems to extend over a prolonged period. Fish with matured roe have been taken as early as May 17th, and ripe fish have also been reported late in June and through July. Very little is positively known as to the location of the spawning grounds of this species, though it is said that they are in deep water.

28. Lake Trout. Salmon Trout. Gray Trout. Togue. Tuladi. Cristimover namaycush (Walbaum). Occasionally taken in Lake Ontario off the Toronto shore. This is the largest species of the family resident in fresh water, reaching a length of several feet and a weight of sixty pounds or even more, though specimens exceeding twenty pounds are now rare. The Lake Trout is one of the most rapacious of our fishes and will devour almost anything, though its principal food consists of Herrings, young Whitefish, and other soft-finned fishes. It frequents deep waters and is usually taken near the bottom. The spawning season commences early in October and continues in December, the ova being deposited on reefs of honeycomb rock in from ten to one hundred feet of water. There is a great difference of opinion as to its value as a game fish. Some anglers consider it affords a great deal of sport; others have no regard for it. I agree with the latter, having always found it a heavy, lumpish fish, with no fight 


\section{NATURAL HISTORY, TORONTO REGION}

in it. Commercially, however, it is of great importance, being always in demand and furnishing an excellent article of food.

29. Brook Trout. Salvelinus fontinalis (Mitchill).-Brook Trout were formerly abundant in all the spring streams near Toronto, but of late years, owing to the pollution of the water and incessant fishing, they have become nearly exterminated. The size attained by this fish depends largely upon its habitat and food. In small streams it may mature at a length of six or eight inches and a weight of only a few ounces, while in large bodies of water, with an abundant food supply, they will reach eighteen inches or more in length and a weight of from six to eight pounds. In the cool days of late autumn the Brook Trout run up to the headwaters of the streams, and there, on the gravelly shallows, deposit their ova; the spawning season extending from September in the north to December in the south. The number of eggs produced depends upon the age and size of the fish. Yearlings (that is, fish in their second year) will produce from fifty to two hundred and fifty ova, while a large fish may produce as many as fifteen hundred. The eggs are about three-sixteenths of an inch in diameter and of a warm orange colour. The period of hatching depends upon the temperature of the water, ranging from thirty-two days in water at $54^{\circ}$ to one hundred and sixty-five days in water at $37^{\circ}$. In the early parts of the summer Trout frequent the ripples and shallower parts of 


\section{FISHES}

the streams, but as the temperature rises and hot weather sets in they retire to the deeper pools or the vicinity of cold springs, where they remain until the return of autumn starts them up stream again. Though commonly called Brook Trout, our fish is really a Charr, and is closely allied to, if not identical with, the famous Charr of North Britain and the continent of Europe.

\section{ORDER HAPLOMI. (Pike-like Fishes.)}

\section{Umbridae. (Mud Minnows.)}

30. Mud Minnow. Dogfish. Umbra limi (Kirtland).-Common and generally distributed in muddy streams and inlets. The name is said to be derived from a habit this fish has of burrowing into the mud when the water evaporates from the ditches and ponds it frequents. It is seldom seen in clear water, preferring to hide at all times under stones or among weeds. It reaches a length of about four inches.

\section{Lucimae. (Pikes.)}

31. Green Pike. Lucius reticulatus (Lesueur). This small Pike does not seem to be at all common in our waters. I have taken a ferw in Toronto Bay. Its usual haunts are weedy streams, ponds and bays, where it lies in wait for the fish, frogs and other living creatures upon which it preys. It is said under favourable circumstances to attain a length 


\section{NATURAL HISTORY, TORONTO REGION}

of two feet and a weight of eight pounds, but those I have seen were never more than half that size. As a food fish it is not generally appreciated, for its flesh seems to have absorbed too strong a flavour of the weeds among which it lives.

32. Common Pike. Northern Pike. Lucius lucius (Linnaeus).-Common and generally distributed in all waters where there are sufficient weeds to afford it shelter. The Pike is one of the most voracious of our fishes, feeding upon any form of animal life which it is able to overpower. Under favourable circumstances it attains a large size, but in Toronto waters it is so constantly pursued that it does not get a chance to attain its full dimensions, and Pike of over ten pounds weight are becoming very rare. Spawning takes place in early spring, as soon as the ice breaks up; the fish running up on to rush beds or grassy shallows for that purpose. The females are very prolific; one weighing thirty-two pounds was estimated by the late Professor Buckland to contain 595,000 ova. Many anglers profess to look upon the Pike with contempt, and treat its claim to be considered a game fish with derision. This is because it is usually taken by them in the summer months, when it is not in good condition. It is then soft in flesh and weedy in flavour; but in the autumn, after the weeds have died down, it is a different fish; then its flesh is firm and good, and its fighting powers will tax the angler's skill to the utmost.

$$
264
$$




\section{FISHES}

\section{Poeciliddae. (The Killifishes.)}

33. Killifish. Fresh-water Killy. Fundulus diaphanus (Lesueur).-Abundant in bays and shallow inlets near the lake; usually found quite close to the shore line, associated in small shoals. A fairly good bait fish, though not as attractive as the bright shiners and chub. This species attains a length of about four inches.

\section{ORDER HEMTBRANCHII. (The Half-gills.)}

Gasterosteidar. (The Sticklebacks.)

34. Brook Stickleback. Eucalia inconstans (Kirtland).-Common in small streams and ponds, where it secretes itself among water plants, ready at any moment to attack any small fish which approaches its lair, or to dart upon passing insects small enough to become its prey. This species is a nest-builder and is particularly vigorous in the defence of its eggs or young. It grows to a length of two and a half inches.

35. Ten-spined Stickleback. Pygosteus pungitius (Linnaeus).-Found in Toronto Bay and Ashbridge's Bay. Not abundant.

36. Two-spined Stickleback. Gasterosteus bispinosus (Walbaum).- - In the breeding season the male is brilliant bluish or greenish above, with indistinct dark bars, and generally bright red below. Length in our waters about three inches. Rather common 


\section{NATURAL HISTORY, TORONTO REGION}

in spring in the inlets and streams falling into Lake Ontario. The male of this species constructs a rather elaborate nest, of sand, pieces of sticks, weeds, etc., in which the female deposits her ova. When this is done the male stands guard over it, fanning with his fins to promote circulation of the water, only leaving his post to dart at an intruder or secure some small insect for foor.

\section{ORDER ACANTHOPTERI.}

\section{GROUP PERCOIDEA. (The Perch-like Fishes.) Centrarchidae. (The Sunfishes.)}

37. Speckled Bass. Calico Bass. Pomoxis sparoides (Lacépède).-The Speckled Bass is found in Ashbridge's Bay, Toronto Bay, and most of the ponds and sluggish streams near Toronto where there is an abundance of aquatic vegetation, under which it lies in wait for the insects, crustaceans and small fish upon which it feeds. It spawns in the early summer, and is said to scoop out a nesting-place in the sand in the same mamner as the Sunfishes and Black Bass. As a food and game fish it stands high in the estimation of anglers, though it is not a very persistent fighter. Being gregarious and congregating in schools, under overhanging weeds and such like places, it may be captured in great numbers when a favourite haunt is discovered. This species readily adapts itself to life in artificial ponds and is 


\section{FISHES}

worthy of much more attention from fish culturists than it has heretofore received, for when taken from clear water it is one of the best table fish we have.

38. Rock Bass. Ambloplites rupestris (Rafinesque).-The Rock Bass grows to a length of about a foot and a weight of a pound and a half, though such large specimens are not often seen now. A common species in all suitable waters of this locality. Its usual haunts are dark holes in streams and lakes, where aquatic regetation flourishes, and it is often to be found in considerable numbers about docks or timber work which shades the water. From these places it emerges towards nightfall and roams about in search of the insects, crustaceans and small fish which form its food. When taken from clear, cold water it is esteemed as a table fish.

39. Blue Sunfish. Lepomis pallidus (Mitchill). -This species was formerly common in Toronto and Ashbridge's Bay, but is now seldom seen. As a table fish it is highly esteemed, and, in proportion to its size, possesses greater fighting qualities than any fresh-water fish we have.

\section{Yellow Sunfish. Pumpkin Seed. Eupomotis} gibbosus (Linnaeus).-Tery common in all waters of this district. Though rather too small to be of value as a game or food fish, yet it affords great sport to the younger anglers, and is by no means to be despised upon the table. Spawning is in May and June, the fish resorting to shallow water, where the ova are deposited in nests scooped out in the sand 
or mud by the action of the fins. Over these the males keep guard until the young are hatched, in the meantime driving off all intruders and promoting circulation of the water by fanning with ventral fins and tail.

\section{Large-mouthed Black Bass. Yellow Bass. Green} Bass. Micropterus salmoides (Lacépède).-At one time this fish was abundant in the waters of this locality, but it is now very scarce. The spawning season begins in May and ends at the beginning of July. A nest is scooped out of the sand or mud, in which the adhesive eggs are deposited. These are guarded by the parent fish until hatched. Incubation lasts from one to two weeks, according to the temperature of the water, and the young bass, after emerging from the eggs, remain in the nest for about a week. As the weather becomes cold this Bass seeks deep places, often hibernating under rocks, sunken logs, or in the mud. In the summer its favourite localities are under overhanging banks or in holes among weeds, where it lies in wait for the frogs, fish and crustaceans which constitute the greater part of its food.

\section{Percidae. (The Perches.)}

42. Yellow Pickerel. Pike-Perch. Dore. Stizostedion vitreum (Mitchill).-The Yellow Pickerel is common in some parts of Lake Ontario, but is not often taken near Toronto. Its spawning time is in early spring, when it runs on to gravelly or sandy 


\section{FISHES}

bars or even up rivers for the purpose of depositing its ova. As soon as the water becomes warm they work off into deep water, where they remain during the hot months. As it is a deep-water fish it does not often afford much sport for the angler, but as a commercial and food fish it is decidedly the best we have in the lakes, its flesh being firm, white, flaky and well flavoured. Under favourable circumstances this species reaches a large size, specimens of twentyfive pounds' weight having been recorded. These are, however, very rare, and a ten-pound fish is now considered a very good one. It is extremely voracious, feeding upon such other fish as it can overpower, and the insects and crustaceans found in its haunts.

43. Sand Pickerel. Blue Pickerel. Sauger. Stizostedion canadense (Smith).-This is a smaller fish than the last, rarely exceeding eighteen inches in length and a weight of two pounds. It is also less valued as a food fish, its flesh being softer and of inferior flavour. Occasionally taken by lake fishermen off the Toronto shore.

44. Yellow Perch. Perca flavescens (Mitchill). - This species reaches a length of ten or twelre inches and a weight of a pound or rather more. The largest I ever saw taken near Toronto weighed one pound and two ounces. It is one of the most abundant of our fishes and is found in all the waters of this locality. As a food fish, if taken when the water is cool it is only excelled by the Yellow Pickerel. 


\section{NATURAL HISTORY, TORONTO REGION}

During the hot summer months the Perch of shallow, weedy waters become soft and lose their fine flavour. To anglers accustomed to Black Bass and Lunge it is rather an insignificant species, but it has this to recommend it, that it can be caught by anybody, with any sort of tackle, at all times of the year. The Perch spawns in early spring, and the eggs, which are very small, are enclosed in a long, narrow translucent strip of adhesive mucus.

45. Tessellated Darter. Boleosoma nigrum olmstedi (Storer).-Common in all streams and sandy bays.

46. Blue Darter. Rainbow Darter. Etheostoma coeruleum (Storer).-Gayest of all the Darters, and, indeed, the gaudiest of all fresh-water fishes. It makes its home in the ripples and shallows of the rivers and in the shady retreats of brooks. In the vicinity of Toronto this fish is rare. I have found it only in two streams on the eastern side of the district.

\section{Serranidae.}

47. White Bass. Roccus chrysops (Rafinesque). - The White Bass is taken occasionally in Toronto Bay and at the mouth of the Humber River. It is gregarious, usually swimming in shoals containing a large number of individuals. As a game fish it ranks high, for it takes minnow bait readily, and during the summer months rises to a fly well. It is an excellent table fish when fresh caught. It spawns in May or June. 


\title{
FISHES
}

ORDER PLECTOGNATHI. (The Plectognathous Fishes.)

\author{
Suborder LORICATI. \\ Cottidae. (The Sculpins.)
}

48. Miller's Thumb. Blob. Cottus ictalops (Rafinesque).-Found in only a few streams in the district.

\section{Suborder ANACANTHINI.}

Gadidae. (Codfishes.)

49. Burbot. Ling. Lota maculosa (Lesueur).This species is common in Lake Ontario and is occasionally taken by the net fishermen in this district.

\section{REFERENCES.}

D. S. Jordan. Manual of the Vertebrates of the Northern United States. 1888.

D. S. Jordan and B. W. Evermann. The Fishes of North and Middle America. Bulletin No. 47. U. S. National Museum, Parts I-IV. 1896-1900.

C. W. Nash. Fishes of Ontario. Department of Education, Ont. 1908. 


\title{
CHAPTER XX.
}

\section{INVERTEBRATES OTHER THAN INSEGTS AND MOLLUSKS.}

By

\author{
A. G. HUNTSMAN, B.A., M.B.
}

Is the following account I have tried to bring together the records for the district aromnd Toronto. They are in most groups utterly inadequate to give a proper idea of the forms that are to be found here. I have included a few forms (indicated by an asterisk) which from their known distribution may be expected to occur here. When not otherwise indicated the identifications are my own. It is hoped that this may be of use as a basis for future records.

\section{Crustacea.}

\section{Decapoda.}

The well-known crayfishes occur abundantly and form an efficient corps of scavengers in all our streams and lakes. They form no inconsiderable element in the food of many of the fishes, frogs and birds.

Cambarus bartonii (Fabr.)-Niagara.*

"6

" robustus Girard-Don River and Indian Creek (Faxon). 


\section{INVERTEBRATES}

Cambarus diogenes Girard-Detroit and Lake Erie.* "6 fodiens (Cottle). (Faxon).

" affinis (Say)-Niagara.*

" propinquus Girard. (Faxon).

" virilis Hagen. (Faxon).

" immunis Hagen-Detroit.*

" rusticus Girard-Lake Erie.*

The following shrimp, received through Dr. E. M. Walker, has been found in the Welland River and may occur here,-

Palaemonetes exilipes Stimpson.*

\section{Schizopoda.}

The deep-water shrimp of the Great Lakes, which forms such a considerable part of the food of the whitefish, is also found in the lakes of Northern Europe. It has doubtless been derived independently on the two continents from the marine Mysis oculata.

Mysis relicta Loven.-Stomach of ling, Port Credit (obtained by Mr. A. R. Cooper).

\section{Amphipoda.}

The small shrimps of this group often swarm along the quiet margins of the lakes, the streams and the ponds and also on the bottom down to considerable depths. They serve as food for many of the fishes.

Pontoporeia hoyi Smith (by Nicholson as P. affinis). 18 
Eucrangonyx gracilis (Smith)-Bond Lake. This is perhaps the Crangonyx (?) sp. of Nicholson from the Bay.

Gammarus fasciatus Say-Humber, Sunnyside, Toronto Bay, Don, etc.

" limnaeus Smith-Georgian Bay.*

Hyalella knickerbockeri (Bate)-Etobicoke, Humber, Black Creek, Sunnyside.

\section{Isopoda.}

The aquatic forms are found in company with the shore forms of the previous group, but they are crawlers rather than swimmers.

Mancasellus tenax (Smith)-Island.

" " dilata (Smith)-Georgian Bay.* Asellus communis Say-Etobicoke, Humber, Sunnyside, Toronto Bay.

The terrestrial species, known commonly as pillbugs or woodlice, are to be found under nearly every board, stone, ete.

Oniscus asellus Linn.-near Niagara.*

Cylisticus convexus (De Geer)-Saginarw, Michigan.*

Porcellio rathkei Brandt.

" spinicornis Say-Niagara.*

" scaber Latreille-Niagara.*

\section{Phyllopoda.}

The phyllopods, though larger than the animals of the three following groups, have a habitat similar 


\section{INVERTEBRATES}

to that of many of the latter. They occur sporadically in large numbers in pools that become dry during the summer months. Like so many of the fresh water animals they have resistant eggs which can withstand drought and frost and which are doubtless transported long distances by water birds.

Pristicephalus gelidus (Hay) - Scarboro Junction. Lynceus gouldii (Baird)-Scarboro Junction. Eulimnadia agassizii Packard-Georgian Bay.*

\section{Cladocera.}

These minute water fleas flourish in abundance in fresh water everywhere. They form the chief food of the fry of many of our fishes. They are often seen swimming around in immense swarms. The only record is

Daphnia pulex?-Tap-water (Acheson).

\section{Ostracoda.}

An examination of debris from the margin or bottom of any pool or stream will show numbers of these minute shelled Crustaceans scrambling over the other objects. The only record for Toronto is a Cypris (?) sp. by Nicholson.

\section{Copepoda.}

These "oar-footed" water fleas are found in a variety of situations in our fresh waters. Best known is "the little Cyclops with one eye" that can be 


\section{NATURAL HISTORY, TORONTO REGION}

found in almost any gathering of water. Our only record of the free-living forms is

Cyclops quadricornis-Tap-water (Acheson).

Many are parasitic in habit, attaching themselves to the gills or skin of fishes. They have been studied by Prof. Ramsay Wright.

Ergasilus centrarchidarum Wright-on Perch, Rock

Bass and Sunfish (Wright).

Actheres micropteri Wright-Black Bass (Wright). Lernaeopoda edwardsii Olsson-on Brook Trout (Wright).

Argulus stizostethii Kellicott-on Lunge and Rock Bass, Georgian Bay.*

\section{Annelida. \\ Oligochaeta.}

In addition to the well-known earthworms, of which there are no Toronto identifications, a large number of aquatic forms, mostly of small size, are to be found here. Only the following have been noted.

Lumbriculus sp.-Toronto Bay (Nicholson). Saenuris canadensis Nichols.-Toronto Bay (Nicholson).

" sp.-Toronto Bay (Nicholson).

Chaetogaster langi Bretscher-Aquaria, Biol. Dept. Nais tortuosa Walton-Aquaria, Biol. Dept. Pristina leidyi Smith-Aquaria, Biol. Dept. 


\section{Hirudinea.}

The leeches or bloodsuckers are partly carnivorous and partly parasitic on our aquatic Vertebrates (principally fish and turtles). For the following list of Toronto species I am indebted to Miss C. G. S. Ryerson.

Glossiphonia stagmalis (L.)-shores and pools everywhere. (Harbour by Nicholson as Clepsine submodesta.)

" complanata (L.)-Humber, Toronto Bay, Don. (Harbour by Nicholson as Clepsine patelliformis).

" heteroclita (L.)-Sunnyside.

Placobdella parasitica (Say)-Etobicoke, Weston. "6 phalera (Graf)-Humber.

Erpobdella punctata (Leidy)-shores and pools everywhere. (Harbour by Nicholson as Nephelis lateralis.)

Piscicola (?) milneri (Verrill).-Humber. Placobdella picta (Verrill)-Grenadier Pond. Haemopis marmoratus (Say)-Etobicoke.

\section{BryozoA.}

These curious "moss-animals" are sedentary. They are found growing in colonies as much as a foot in diameter, attached to all sorts of objects in the water.

Paludicella articulata

(Ehrenberg)-Georgian Bay.* 


\section{NATURAL HISTORY, TORONTO REGION}

Fredericella sultana (Blumenbach)-Bond Lake. Plumatella repens (L.)-High Park, Don. " emarginata Allman-Etobicoke. " punctata Haucock-Georgian Bay.* Cristatella mucedo Cuvier-Georgian Bay.* Pectinatella magnifica (Leidy)-Humber (Osler).

\section{) Rotifera.}

The wheel-animalcules are favourite objects of study for the naturalist with a microscope. Jennings has listed 164 species as occurring in the Great Lakes. Lake Ontario has been scarcely touched.

Bovell notices the following from the Humber and Island Ponds,-

Megalotrocha alboflavicans Ehrenb.

Floscularia ornata Ehrenb.

Rotifer vulgaris Schrank.

Acheson lists from tap-water,Anuraea stipata Ehrenb.

Brachionus sp.

\section{Nematelminthes.}

The round or thread worms are to be found as internal parasites of practically all our vertebrates, including man himself. Many forms also occur in water or in moist earth.

Anguillula fluviatilis-Tap-water (Acheson). Ascaris microcephala Rud.?-in Bittern (Wright). 


\section{INVERTEBRATES}

Ascaris lumbricoides L.-in Man.

66

" suum Goeze-in Pig.

" equorum Goeze-in Horse.

Filaria triaeuncha Wright-in Bittern (Wright). Ancyracanthus cystidicola (Schn.)-in Salmon (Wright).

Ancyracanthus serratus Wright-in Whitefish (Wright).

Echinorhyncus sp.-in Whitefish (Morris). Gigantorhyncus gigas (Goeze)-in Pig.

From Montgomery's account of the hair-worms or hair-eels (Proc. Ac. Phil., vol. 59) there are perhaps four species that may be expected to occur here.

\section{Platyhelmixthes.}

\section{Turbellaria.}

The free-living flat-worms or Planarians are abundant in our waters and may be found on the under surfaces of stones, etc. None seem to have been reported from Toronto.

\section{Trematoda.}

These animals are when adult internal or external parasites of vertebrates (for the most part).

Sphyranura osleri Wright-in Mud-puppy (Wright). Polystoma oblongum Wright - in Mud-turtle (Wright).

Octobothrium sagittatum (Leuck.) - in Sucker (Wright). 


\section{NATURAL HISTORY, TORONTO REGION}

Fasciola reticulata (Wright) - in Kingfisher (Wright).

Echinostoma asperum (Wright) - in Bittern (Wright).

Glypthelmins quieta Stafford-in Bullfrog (Stafford).

Haematoloechus longiplexus Staff.-in Bullfrog (Stafford).

" breviplexus Staff.-in Bullfrog (Stafford).

“ varioplexus Staff.-in Bullfrog (Stafford).

" similiplexus Staff.-in Toad and Green Frog (Stafford).

Ostiolum medioplexum (Staff.) -in Toad and Green Frog (Stafford).

Gorgodera amplicava Loos-in Bullfrog (Bensley, Stafford).

Gorgoderina simplex Loos-in Bullfrog (Bensley, Stafford).

“ attenuata Staff.-in Bullfrog and Green Frog (Stafford).

" translucida Staff.-in Toad and Green Frog (Stafford).

" opaca Staff.-in Toad (Stafford).

Loxogenes arcanum (Nickerson)-in Bullfrog (Stafford).

Halipegus occidualis Staff.-in Bullfrog (Stafford). Clinostomum heterostomum

(Rud.)-in Bittern

(Wright). 


\section{INVERTEBRATES}

\section{Cestoda.}

The tape-worms are internal parasites of vertebrates. Their larvae (cysticerci or bladder-worms) are parasites of other vertebrates or of invertebrates. Dr. E. M. Walker has given me the following list of species that are found here. It is merely a beginning.

Dipylidium caninum (L.) - in the Dog and Cat (adult).

Taenia serrata Goeze-in the Rabbit (cysticercus). " saginata Goeze-in Man (adult). " echinococcus v. Sieb.-in Man (cysticercus). " serialis (Gerv.) -in the Rabbit (cysticercus).

\section{Coelenterata.}

Our only representative of this group that contains so very many marine species is the well-known Hydra, that has been the subject of such a large number of experiments in regeneration.

Hydra viridissima Pallas-(Dr. E. M. Walker). polypus L.-Sunnyside.

" oligactis Pallas-Michigan.*

" vulgaris Pallas-Michigan.*

\section{Porifera.}

Our fresh-water sponges are few in kinds, but often grow in great luxuriance. 


\section{NATURAL HISTORY, TORONTO REGION}

Carterius tubisperma Mrills—Sunnyside. Spongilla lacustris Linn.*

" fragilis Leidy.*

Ephydatia fluviatilis (L.) is probably the sponge recorded from Grenadier Pond by Goadby and Borell as Spongia fluviatilis.

\section{Protozoa.}

These simplest forms of animal life form a considerable part of the plankton or floating life of our waters, and also occur in debris on the bottom and in moist situations of all kinds. Parasitic species are to be found in members of all the other groups, and they even parasitize other Protozoa. The few species reported from this district are,-

(1) By Bovell, from the Humber and Island Ponds,

Amoeba princeps.

Stentor caeruleus.

Vorticella convallaria.

Leucophrys patula.
Kolpoda cucullus.

Paramecium aurelia.

Oxytricha gibba.

Chilodon cucullus.

(2) By Acheson, from tap-water,

Amoeba proteus. 66 radiosa.

Difflugia globulosa. Actinophrys sol. Acanthocystis turpacea? Monas lens. Dinobryon sertularia.
Dinobryon stipitatum. Salpingoeca fusiformis. Asterosiga sp. Stylobryon petiolatum. Peridinium sp. Vorticella sp. Steritor sp. 282 


\section{INVERTEBRATES}

\section{GENERAL REFERENCES.}

\section{Decapoda.}

Faxon, W. A. A Revision of the Astacidae. Mem. Mus. Comp. Zool. Harr., Nol. X, No. 4. 1885.

Hagen, H. A. Monograph of the North American Astacidae. Illus. Cat. Mus. Comp. Zool. Harv., No. III. 1870.

\section{Schizopoda and Amphipoda.}

Smith, S. I. The Crustacea of the Fresh Waters of the United States. Rep. U. S. Comm. Fisheries, Pt. 2 for 1872-1873, p. 637. 1874.

Weckel, A. I. The Fresh-water Amphipoda of North America. Proc. U.S.N. Mus., Vol. XXXII, p. 25. 1907.

\section{Isopoda.}

Richardson, H. Monograph on the Isopods of North America. Bull U.S.N. Mus., No. 54. 1905.

\section{Phyllopoda.}

Daday, E. Monographie systématique des Phyllopodes anostracés. Annal. Sc. Nat., Zool., ser. 9, Vol. XI, p. 91.1910.

Packard, A. S. A Monograph of the Phyllopod Crustacea of North America, with Remarks on the Order Phyllocarida. Hayden's 12th Ann. Rep. U. S. Geol. \& Geogr. Surv. Terr., Year 1878. Sec. II, Zool., p. 295. 1883. 


\section{NATURAL HISTORY, TORONTO REGION}

\section{Cladocera.}

Herrick, C. L. Cladocera of Minnesota. Second Report of State Zoologist, Pt. II. Geol. \& Nat. Hist. Surv. Minn., Zool. Series II. 1895.

\section{Ostracoda.}

Turner, C. H. Fresh-water Ostracoda of the United States. Second Report of State Zoologist, Pt. II, Geol. \& Nat. Hist. Surrv. Minn., Zool. Series II. 1895.

Copepoda (free-living).

Herrick, C. L. Copepoda of Minnesota. Second Report of State Zoologist, Pt. II. Geol. \& Nat. Hist. Surv. Minn., Zool. Series II. 1895.

\section{Copepoda (parasitic).}

Bassett-Smith, P. W. A Systematic Description of Parasitic Copepoda, etc. Proc. Zool. Soc. London for 1899, p. 438.

\section{Annelida.}

Beddard, F. E. A Monograph of the Order Oligochaeta. Oxford, 1895 .

Moore, J. P. Hirudinea and Oligochaeta collected in the Great Lakes Region. Bull. U. S. Bur. Fisheries, Vol. XXV, p. 155. 1906. Walton, L. B. Naididae of Cedar Point, Ohio. Amer. Nat., Vol. XL, p. 683. 1906. 


\section{INVERTEBRATES}

\section{Bryozoa.}

Davenport, C. B. Report on the fresh-water Bryozoa of the United States. Proc. U. S. N. Mus., Vol. XXVII, p. 211. 1904.

Kraepelin, K. Die Deutschen Susswasser-Bryozoen.

Abh. Natur. Ver. Hamburg, Bd. XVIII. 1887.

\section{Rotifera.}

Jennings, H. S. Rotatoria of the United States, with special reference to those of the Great Lakes. Bull. L. S. Fish Comm., Vol. XIX, p. 67.1901.

\section{Nematelminthes.}

Montgomery, T. H. The Gordiacea of certain American collections, with particular reference to the North American Fauna. Bull. MIus. Comp. Zool. Harv., Vol. XXXII, p. 23. 1898.

\section{Porifera.}

Potts, E. Contributions towards a synopsis of the American Forms of fresh-water Sponges, etc. Proc. Ac. Nat. Sc. Philad., Vol. XXXIX, p. 158. 1887.

\section{Protozoa.}

Kent, W. Saville. A Manual of the Infusoria. Vols. I-III. London, 1880-1883.

Cash, J. The British Freshwater Rhizopoda and Heliozoa. Vols. I \& II. 1905 \& 1908. Published by the Ray Society. 


\section{NATURAL HISTORY, TORONTO REGION}

\section{SPECIAL REFERENCES.}

Acheson, G. Biological Study of the Tap-water in the School of Practical Science, Toronto. Proc. Can. Inst., ser. 3, Vol. I, p. 413. 1883. Bensley, R. R. Two forms of Distomum eygnoides. Centralbl. Bakter., Vol. XXI, p. 326. 1897. Bovell, J. Note on the Preservation of some Infusoria, etc. Canad. Journ., new ser., Vol. VIII, p. 341. 1863.

Cottle, T. J. On the two species of Astocus found in Upper Canada. Canad. Journ, new ser., Vol. VIII, p. 216. 1863.

Faxon, W. A. A Revision of the Astacidae. Mem. Mus. Comp. Zool. Harv., Vol. X, No. 4. 1885 .

Goadby \& Borell, J. Passing Visits to the Rice Lake, Humber River, Grenadier's Pond, and the Island. Canad. Journ., Vol. III, p. 201. 1855 .

Hincks, T. On a supposed Pterobranchiate Polyzoon from Canada. Ann. Mag. Nat. Hist., March, 1880.

Morris, B. R. Description of an Intestinal Worm from the Duodenum of the White Fish of the Canadian Lakes. Canad. Journ., new ser., Vol. IV, p. 442.1859.

Nicholson, H. A. Contributions to a Fauna Canadensis, being an Account of the Animals dredged in Lake Ontario in 1872. Canad. Journ., new ser., Vol. XIII, p. 490. 1873. 286 


\section{INVERTEBRATES}

Osler, W. On Canadian Fresh-water Polyzoa (Note,

p. 405). Canad. Natur., new ser., Vol. $X$,

p. 399.1883.

Stafford, J. Some undescribed Trematodes. Zool.

Jahrb., System., Bd. XIII, p. 399. 1900.

Stafford, J. On the American Representatives of

Distomum variegatum. Zool. Jahrb., System., Bd. XVI, p. 895. 1902.

Stafford, J. The American Representatives of Distomum cygnoides. Zool. Jahrb., System., Bd. XVII, p. 411.1903.

Stafford, J. Trematodes from Canadian Vertebrates.

Zool. Anzeig., Vol. XXVIII, p. 681. 1905. Wright, R. R. Contributions to American Helminthology. No. I. Proc. Can. Inst., ser. 3, Vol. I, p. 54. 1884.

Wright, R. R. Notes on American Parasitic Copepoda. No. I. Proc. Can. Inst., ser. 3, Vol. I, p. 243.1884 . 


\section{CHAPTER XXI.}

\section{MOLLUSCA.}

By

\section{A. D. ROBERTSON, B.A.}

Tre sources frum which the following list is compiled are various. Records of Mollusca collected in the neighbourhood of Toronto are to be found in papers by A. E. Tilliamson and Prof. Nicholson. The Hon. Justice F. R. Latchford has also kindly supplied me with a list of forms which he has collected. In addition to these lists the collections of Dr. William Brodie in the Biological Museum, University of Toronto, and at the Education Department, as well as those made by Dr. A. G. Huntsman and the writer, were examined. Specimens in Dr. Brodie's collection are indicated by the abbreviation (B); those in Judge Latchford's list by (L).

The nomenclature follows as far as possible that of Dall's Land and Fresh-water Mollusks in the Reports of the Harriman Alaska Expedition.

Gasteropoda Prosobranchiata.

Family Valvatidae.

Valvata tricarinata, Say. Toronto Bay, Grenadier Pond, Etobicoke Creek.

" sincera, Say. Grenadier Pond.

" piscinalis, Müller. ? 


\section{MOLLUSCA}

Family Viviparidae.

Campeloma decisa, Say.

\section{Gasteropoda Pulmonata (Terrestrial).}

Family Helicidae.

Vallonia pulchella, Müller. (L).

Polygyra tridentata, Say. (B). Scarborough Bluffs.

" albolabris, Say. Don River.

" palliata, Say. (B).

" monodon, Rackett. (B).

Family Pupidae.

Bifidaria armifera, Say. (L). Humber River.

Vertigo milium, Gould. Scarborough Bluffs.

Family Achatinidae.

Cochlicopa lubrica, Müller. (L). Humber River.

Family Circinariidae.

Circinaria concava, Say (B).

Family Zonitidae

Vitrea cellaria, Müller. (B), (L).

Zonitoides arborea, Say. (L). Don River, Humber

River, Centre Island.

Gastradonta ligera, Say.

Omphalina fuliginosa, Griffith. (L).

\section{Family Limacidae.}

Agriolimax agrestis, Linnaeus. (L). Don River,

Humber River, Centre Island. 


\section{NATURAL HISTORY, TORONTO REGION}

Agriolimax campestris, Say. (L). Humber River,

Centre Island, Scarborough Bluffs.

Arion circumscriptus, Johnston.

\section{Family Endodontidae.}

Pyramidula alternata, Say. (B), (L). Don River,

Humber River, Scarborough Bluffs.

“ cronkhitei anthonyi, Pilsbry. Scarborough Bluffs.

\section{Family Succineidae.}

Succinea retusa, Lea. High Park, Centre Island. " avara, var. vermeta, Say.

\section{Family Philomycidae.}

Pallifera dorsalis, Binney (L).

Gasteropoda Pulmoxata (Aquatic).

Family Limnaeidae.

Lymnaea stagnalis, Linné. (L). Centre Island, Grenadier Pond.

66 columella, Say. Grenadier Pond, Etobicoke Creek. catascopium, Say. (L). High Park.

“ palustris, Müller. Don River, High

Park, Centre Island, Scarborough Bluffs.

“ reflexa, Say. (B) (L).

" gracilis, Jay. (L).

" caperata, Say. (L).

" humilis modicella, Say. (L). 


\section{MOLLUSCA}

Planorbis bicarinatus, Say (B), (L). Grenadier Pond, Etobicoke Creek, Humber River.

“ trivolvis, Say. (B), (L). Grenadier

Pond, Centre Island.

“ campanulatus, Say. (B). Grenadier

Pond.

" exacuous, Say. (B). Grenadier Pond,

Scarborough Bluffs.

“ deflectus, Say.? (B).

" parvus, Say. (B). Grenadier Pond, Eto-

bicoke Creek, Scarborough Bluffs.

“ crista, Linné.? Grenadier Pond.

\section{Family Physidae.}

Physa heterostropha, Say.? (B). ancillaria, Say. Grenadier Pond, Don River,

Etobicoke Creek, Humber River.

“ integra, Haldeman. Don River, Etobicoke Creek.

Ancylus parallelus, Haldeman. Etobicoke Creek, Centre Island, Grenadier Pond.

" tardus, Say. Grenadier Pond.

" rivularis, Say. Creek in North Toronto.

\section{Family Amnicolidae.}

Imnicola limosa, Say. (B). Grenadier Pond, Eto-

bicoke Creek, Centre Island, Don

River.

" emarginata, Küster.

iythinia tentaculata, Linné. (L). 
Family Streptomatidae.

Goniobasis livescens, Menke. (L). Etobicoke Creek,

Humber River.

" virginica, Gmelin.? Toronto Bay.

\section{Pelycypoda.}

Family Unionidae.

Lampsilis luteolis, Lamarck. (B).

" radiatus, Gmelin. (B).

" ellipsiformis, Conrad. (B).

" ochraceus, Say.?

Anodonta grandis, Say. (B), (L). Centre Island.

" grandis, var. benedictensis, Lea. (B).

" cataracta, Say. (L). Centre Island.

Anodontoides ferussacianus, Lea. (B).

" ferussacianus, var. subcylindraceus, Lea. (L). Don River.

Symphynota compressa, Lea. (B), (L).

Unio complanatus, Solander. (B).

" crassidens, Lamarck.?

" gibbosus, Barnes. (B).

"nasutus, Say. (L).

" rectus, Lamarck. (L).

Family Sphaeriidae.

Sphaerium simile, Say. (B), (L). Grenadier Pond.

" striatinum, Lamarck. (L).

" stamineum, Conrad. (L).

" (Musculium) securis, Prime. Don River,

Centre Island, High Park. 


\section{MOLLUSCA}

Sphaerium (Musculium) partumeium, Say. (L). High Park.

“ (Musculium) transversum, Say. High Park.

“ (Musculium) truncatum, Linsley. Grenadier Pond.

Pisidium abditum, Haldeman. Centre Island, Grenadier Pond.

“ variabile, Prime. (L).

\section{REFERENCES.}

Baker, F. C. The Lymnaeidae of North and Central America. Chicago Academy of Sciences. Special Publication No. 3. 1911.

Baker, F. C. The Mollusca of the Chicago Area. Chicago Academy of Sciences, Bull. No. 3., 1898-1902.

Baker, H. B. Key to the Genera of Gastropoda of Michigan, Eleventh Report, Michigan Academy of Sciences. 1909.

Binney, W. G. Land and Fresh-water Shells of North America, Parts II and III, Smithsonian Misc. Coll., vol. 7. 1865.

Binney, W. G., and Bland, T. Land and Freshwater Shells of North America, Part I, Smithsonian Misc. Coll., vol. 8. 1869.

Nicholson, H. A. Contributions to a Fauna Canadensis. The Canadian Journal, New Series, vol. 13, 1872. 


\section{NATURAL HISTORY, TORONTO REGION}

Prince, T. Monograph of American Corbiculadae, Smithsonian Mise. Coll., vol. 7. 1865.

Tryon, G. W., Jr. Land and Fresh-water Shells of North America, Part IV, Smithsonian Misc. Coll., vol. 16. 1873.

Walker, Bryant. An Illustrated Catalogue of the Mollusca of Michigan. Report of the Geological Survey of Michigan for 1905. Lansing, 1906.

Williamson, A. E. Notes on Land and Fresh-water Shells collected in the Environs of Toronto. The Canadian Journal, New Series, vol. 6. 1861. 


\section{CHAPTER XXII.}

\section{INSEGTS AND THEIR ALLIES.}

By

E. M. WALKER, B.A., M.B.

JoDGing from its insect fauna, Toronto lies approximately on the boundary line between the Transition and Upper Austral Zones of Merriam. A number of species common in the Niagara Peninsula reach their northern limits in about this vicinity, particularly in the Don and Humber Valleys and in the sandy uplands of High Park and the adjoining country.

Ten years ago it was not necessary for the entomologist to travel far beyond the city limits in order to secure a good representation of the species of any order of insects native to the Toronto district. With the rapid growth of the suburbs of late years, however, many of the old hunting grounds have been cut up by new streets and converted into building lots, golf-grounds, etc., so that the entomologist must now go farther and farther afield in order to provide himself with specimens of all the species that once were obtainable within the city limits.

For general collecting the old Belt Line and the Humber, Don and Credit Valleys, Highland and Black Creeks are to be recommended. For species 


\section{NATURAL HISTORY, TORONTO REGION}

inhabiting sandy fields and open sandy woods High Park is still a good locality, and many other arenaceous forms, particularly among the beetles, may be taken on Toronto Island. Aquatic species may be collected in Grenadier Pond (High Park), the Humber River, Etobicoke Creek, the upper part of the Don and in the lagoons of Toronto Island. Large quantities of material of many species, especially beetles, are sometimes cast up on the beach drift of the Island.

For a city of its size comparatively little collecting has been done about Toronto, and some of the smaller orders have been wholly neglected. The largest general collection is that of the late Dr. Wm. Brodie, now in the Provincial Mruseum. The list of Hymenoptera is for the most part merely a list of the named species in this collection. It is believed that they were authentically determined, as Dr. Brodie was in the habit of sending his specimens to Ashmead and other specialists at Washington for determination. This is certainly the case in regard to the Chalcidoidea. The list of Cynipoidea and the gall-forming Tenthredinidae were for the most part furnished by Dr. A. Cosens. For the list of Coleoptera I am indebted to Mr. R. J. Crew, who has collected beetles extensively about Toronto. His specimens were determined by Prof. Wickham. The Lepidoptera have been kindly listed by Mr. A. Gibson, of Ottawa, his list being mainly based on his own collections. The Diptera have not been 


\section{INSECTS AND THEIR ALLIES}

systematically collected by anyone to my knowledge. Most of the names here listed were kindly contributed by Mr. M. C. Van Duzee, of Buffalo, who has, however, collected at Toronto on very few occasions. The Cecidomyidae were listed by Dr. Cosens. Most of the Syrphidae were collected by Dr. Brodie, and some additional species by the writer. A number of species in other families were also listed from Dr. Brodie's collection, while the Dolichopodidae, in addition to the species taken by Mr. Van Duzee, were collected and determined by the writer. In the Hemiptera, very little collecting has been done, and the few species listed, with the exception of the Aphididae and Coccidae, are in the collection of the Provincial Museum. The Aphididae are nearly all gall-forming species, the list having been kindly furnished by Dr. Cosens. The Coccidae, with one or two exceptions added by the writer, were taken from Mr. T. D. Jarvis's list of the Coccidae of Canada (41st Ann. Rep. Ent. Soc. Ont., 1910, p. 64-77). The Orthoptera and Odonata were collected and determined by the writer and are believed to be fairly complete. The few species belonging to the other orders listed were determined by Messrs. Nathan Banks and W. A. Clemens (Ephemeridae).

In addition to the gentlemen mentioned in the preceding paragraph, I have been ably assisted in the preparation of these lists by Messrs. J. C. Crawford, H. L. Viereck and S. A. Rohwer, who kindly revised 


\section{NATURAL HISTORY, TORONTO REGION}

the list of Hymenoptera, and by Mr. E. P. Van Duzee, who arranged the list of Hemiptera, exclusive of the Aphididae and Coccidae. To all of these gentlemen I desire to express my sincere thanks.

\section{Class ARACHNIDA.}

The Arachnids of the Toronto district have been almost entirely neglected, and are practically unknown. The only records I have found are those. of a few mites taken by Mr. J. B. Tyrrell from birds in 1878-1880 and described by Dr. C. Haller in the "Archiv für Naturgeschichte" for 1882. The following is a list of these species, revised by Mr. Nathan Banks:

Pteronyssus simplex, Haller.

Analges digitatus, Haller.

" passerinus, Linn.

" tridentulatus, Haller.

Megninia aculeatus, Hailer.

" forcipatus, Haller.

" gladiator, Haller.

" pici-majoris, Buchholz.

Allanalges gracilepinneata, Haller.

Class DIPLOPODA and Class CHILOPODA.

Neither the Millipedes nor the Centipedes of the Toronto district have received any attention from zoologists. 


\section{INSECTS AND THEIR ALLIES}

\section{Class INSECTA.}

\section{Order ORTHOPTERA.}

Blattidae (Cockroaches).

Ischnoptera pennsylvanica, De G. Not uncommon.

$$
\text { " borealis, Rehn. Rare. }
$$

Blattella germanica, Linn. Common in old houses. Blatta orientalis, Linn. Common in old houses. Periplaneta australasiae, Fab. Sometimes introduced on bananas.

Nyctibora holosericea, Burm. Introduced on bananas.

" sericea, Burm. Introduced on bananas. Leucophaea surinamensis, Linn. Introduced on bananas.

Panchlora virescens, Thunb. Introduced on bananas.

\section{Phasmidae (Stick Insects).}

Diapheromera femorata, Say. Not uncommon.

Locustidae (Acrididae, Auctt.) (Short-horned Grasshoppers, Locusts).

Tettix granulatus, Kirby. Common in swamps. " ornatus, Say. Low grounds.

" hancocki, Morse. Not rare. Dry hillsides. " obscurus, Hanc. Low meadows and swales. Paratettix cucullatus, Burm. Margins of streams, locally common.

Tettigidea parvipennis, Harr. Common. 


\section{NATURAL HISTORY, TORONTO REGION}

Chloealtis conspersa, Harr. Common.

Orphulella speciosa, Scudd. Common in High Park. Chorthippus curtipennis, Harr. Common in low grounds.

Mecostethus lineatus, Scudd. Open swamps.

Arphia xanthoptera, Germ. Only one Toronto record.

" sulphurea, Fab. Scrubby, sandy uplands. common.

Chortophaga viridifasciata, De G. Fields, common. Encoptolophus sordidus, Burm. Dry fields, common. Camnula pellucida, Scudd. Sandy fields, abundant. Hippiscus tuberculatus, Beaur. Open sandy hillsides, High Park.

Dissosteira carolina, Linn. Roadsides, abundant. Spharagemon bolli, Scudd. Dry hillsides, High Park.

Trimerotropis maritima, Harr. Sandy beaches, Toronto Island.

Schistocerca americana, Drury. Once reported, a visitor from the South.

Melanoplus atlanis, Riley. Fields, abundant.

“ femur-rubrum, De G. Abundant.

“ fasciatus, Walk. Open woods, scarce.

" dawsoni, Scud. Sandy, scrubby fields,

High Park. A western species.

" islandicus, Blatchl. Openings in rich woods.

" minor, Scudd. Sandy fields, High Park.

“ luridus, Dodge. Dry fields, common. 


\section{INSECTS AND THEIR ALLIES}

Melanoplus bivittatus, Say. Swamps and low grounds, common.

" punctulatus, Scudd. On pine trees, rare.

Tettigoniidae (Locustidae, Auctt.) (Long-horned Grasshoppers and Katydids).

Amblycorypha oblongifolia, De G. Trees and bushes, rare.

Scudderia pistillata, Brunner. Bushes in swamps, northern.

" furcata, Brunner. Trees and bushes, common.

" curvicauda, De G. Trees and bushes, common.

Conocephalus ensiger, Harr. Fields and waste places, common.

Orchelimum vulgare, Harr. Long grass in low fields, common.

Xiphidion fasciatum, De G. Low meadows and swamps, common.

66 brevipenne, Scudd. Weeds and rank vegetation, common.

" saltans, Scudd. Long grass in dry fields,

High Park. A western species.

66 nigropleura, Scudd. Open swamps,

High Park, rare.

Ceuthophilus pallipedes, E. Walk. Rich woods, not rare.

“ neglectus, Scudd. Rich woods, High Park, rare.

6 terrestris, Scud. Rare. 301 


\section{Gryllidae (Crickets).}

Tridactylus apicalis, Say. Damp sandbars along streams.

Gryllus pennsylvanicus, Burm. Abundant.

" " abbreviatus, Serv. Abundant.

" domesticus, Linn. Toronto General Hospital.

Nemobius griseus, E. Walk. Sandy fields, High Park.

" fasciatus, De G. Grassy places, very abundant.

" carolinus, Scudd. Low pastures, common. Oecanthus niveus, De G. Shade and fruit trees, common.

" nigricornis, Walk. Bushes and rank vegetation, common. " " quadripunctatus, Beut. Rank regetation, common.

\section{Order DERMATOPTERA.}

Forficulidae (Earwigs).

Labia minor. Scudd. One specimen.

\section{Order PLECOPTERA.}

\section{Perlidae.}

Nemoura perfecta, Walk.

Isogenus frontalis, Newm. 


\section{INSECTS AND THEIR ALLIES}

\section{Order EPHEMERIDA.}

\section{Ephemeridae.}

Hexagenia bilineata, Say.

Ephemera simulans, Walk.

Heptagenia canadensis, Walk.

" tripunctata, Banks.
" $\quad$ fusca, Clemens (MS).
luridipennis, Burm.

Ecdyurus maculipennis, Walsh. " lucidipennis, Clemens (MS).

Blasturus sp.?

Caenis diminuta, Walk.

Siphlurus alternatus, Say.

Baetis propinquus, Walsh.

6 sp. nov.

Callibaetis ferrugineus, Walsh.

\section{Order ODONATA.}

Suborder Zygoptera (Damsel flies).

\section{Calopterygidae.}

Calopteryx maculata, Burm. Common along streams.

\section{Agrionidae.}

Lestes unguiculatus, Hag. Ponds, common.

" uncatus, Kirby. Ponds.

" disjunctus, Hag. Ponds and lagoons, abundant.

" rectangularis, Say. Ponds, common.

“ vigilax, Selys. Grenadier Pond, abundant. 


\section{NATURAL HISTORY, TORONTO REGION}

Argia moesta putrida, Hag. Bond Lake.

Nehalennia irene, Hag. Common.

Amphiagrion saucium, Burm. Very local. Agrion resolutum, Selys. Ponds, locally abundant. Enallagma hageni, Walsh. Very abundant.

66

66

66

66

66

6

66

66

Ischnura verticalis, Say. Abundant. ward.

ebrium, Hag. Abundant.

exsulans, Hag. dier Pond. common. mon.

calverti, Morse. Rare; commoner north-

geminatum, Kell. Common at Grena-

carunculatum, Morse. Grenadier Pond,

antennatum, Say. Don River, abundant. signatum, Hag. Grenadier Pond, com-

pollutum, Hag. Grenadier Pond.

Suborder Anisoptera (Dragonflies).

\section{Aeshnidae.}

Hagenius brevistylus, Selys. Very rare.

Ophiogomphus rupinsulensis, Walsh.

Gomphus exilis, Selys. Grenadier Pond.

“ villosipes, Selys. Don Valley, not common.

" furcifer, Hag. Grenadier and neighbouring ponds, not uncommon.

Dromogomphus spinosus, Selys. Grenadier Pond, rare. 


\section{INSECTS AND THEIR ALLIES}

Basiaeschna janata, Say. Bond Lake. Aeshna eremita, Scudd. Grenadier Pond, rare. " canadensis, Walk. Common. " verticalis, Hagen. Common. “ tuberculifera, Walk. Hunt Club, Etobicoke Creek, rare.

“ umbrosa, Walk. Common. " constricta, Say. Common. Anax junius, Dru. Very abundant. Epiaeschna heros, Fabr. Rather scarce.

\section{Libellulidae.}

Epicordulia princeps, Hag. Grenadier and neighbouring ponds, rather scarce.

Tetragoneuria cynosura, Say. Abundant.

dant.
spinigera, Selys. Grenadier Pond,
rare.

Cordulia shurtleffi, Scudd. One specimen; a northern species.

Somatochlora williamsoni, E. Walk. One specimen; commoner northward.

Libellula exusta julia, Uhl. Grenadier Pond, one specimen; abundant northward.

“ luctuosa, Burm. High Park, common. “ pulchella, Dru. Ponds and ditches, abundant.

“ semifasciata, Burm. Pools, common. 


\section{NATURAL HISTORY, TORONTO REGION}

Libellula quadrimaculata, Linn. Ponds, very common.

Plathemis lydia, Dru. Ponds and ditches, abundant. Erythemis simplicicollis, Say. Ponds, common.

Pachydiplax longipennis, Burm. Abundant, especially at Grenadier Pond.

Sympetrum costiferum, Hag. Don Valley and Island lagoons, common.

" vicinum, Hag. Ponds and marshes, common.

“ semicinctum, Say. Ponds, rare.

" rubicundulum, Say. Abundant.

" obtrusum, Hag. Abundant.

" corruptum, Hag. Humber River, one specimen.

Leucorrhinia intacta, Hag. Very abundant, especially at Grenadier Pond.

Celithemis eponina, Dru. Grenadier Pond.

" elisa, Hag. Grenadier Pond.

Tramea carolina, Linn. High Park, one specimen.

“ lacerata, Hag. Grenadier Pond.

\section{Order HEMIPTERA.}

Suborder PaRAstTica.

Pediculidae (Lice).

Phthirius inguinalis, Leach.

Pediculus capitis, De G.

" vestimenti, Leach.

306 


\section{INSECTS AND THEIR ALLIES}

\section{Suborder Homoptera.}

Cicadidae (Cicadas).

Okanagana rimosa, Say.

Cicada sayi, Sm. \& Gros.

Fulgoridae (Lantern-flies, etc.).

Ormenis pruinosa, Say.

Cercopidae (Spittle Insects).

Aphrophora parallela, Say.

$$
\text { " quadrinotata, Say. }
$$

Membracidae (Tree-hoppers).

Ceresa bubalus, Fab.

$$
\text { " diceros, Say. }
$$

Thelia godingi, $\nabla$ an D.

Telamona ampelopsidis, Harr.

"unicolor, Fitch.

Smilia camelus, Fab.

Enchenopa binotata, Say.

Tettigoniellidae (Leaf-hoppers).

Oncometopia costalis, Fab.

Helochara communis, Fitch.

Diedrocephala coccinea, Forst.

Draeculacephala mollipes, Say.

Jassidae (Leaf-hoppers).

Scaphoideus immistus, Say.

Typhlocyba comes, Say.

Aphididae (Plant Lice).

Chermes abietis, Chol.

" floccus, Patch.

" pinicorticis, Fitch. 
Aphididae (Plant Lice)-(Continued).

Chermes similis, Gillette.

Hormaphis hamamelidis, Fitch.

" spinosus, Shiner.

Pemphigus imbricator, Fitch.

$\begin{array}{ll}\text { “ } & \text { populicaulis, Fitch. } \\ \text { “ } & \text { tessellata, Fitch. } \\ \text { “ } & \text { ulmi-fusus, Walsh. } \\ \text { vagabundus, Walsh. }\end{array}$

Colopha ulmicola, Fitch.

Schizoneura lanigera, Hartig.

Aleyrodidae (Aleyrodes).

Aleyrodes forbesi, Ashm. (Jarvis).

Coccidae (Scale Insects).

Orthezia insignis, Dougl.

Kermes pettiti, Ehrh.

" pubescens, Bogue.

Gossyparia spuria, Mod.

Pseudacoccus citri, Risso.

Pulvinaria innumerabilis, Rathv.

Coccus hesperidum, Linn.

Eulecanium quercifex, Fitch.

"

cerasifex, Fitch.

“ vini, Bouche.

Physakermes piceae, Schr.

Chionaspis furfura, Fitch.

" pinifoliae, Fitch.

Aspidiotus aesculi, Johns.

“ ancylus, Putn.

“ osborni, Newell \& Ckll.

308 


\section{INSECTS AND THEIR ALLIES}

Coccidae (Scale Insects)-(Continued).

Aspidiotus ulmi, Johns.

Lepidosaphes ulmi, Linn.

Suborder Heteroptera.

Thyreocoridae (Negro-bugs).

Thyreocoris unicolor, P.B.

" pulicarius, Germ.

Pentatomidae (Stink-bugs).

Eurygaster alternatus, Say.

Mormidea lugens, Fab.

Chlorochroa persimilis, Horv.

Euschistus filipes, Say.

" fissilis, Uhl.

" tristigmus, Say.

" variolarius, Beauv.

Coenus delius, Say.

Cosmopepla carnifex, Fab.

Perilloides circumcinctus, Stal.

" claudus, Say.

Podisus cynicus, Say.

" modestus, Dall.

Coreidae (Squash-bug Family).

Anasa tristis, De G.

Alydus eurinus, Say.

Lygaeidae (Chinch-bug Family).

Lygaeus turcicus, Fab.

Cymus discors, Horv.

Tingitidae (Lace-bugs).

Corythuca arcuata, Say. 


\section{NATURAL HISTORY, TORONTO REGION}

Saldidae (Shore-bugs).

Salda coriacea, Uhl.

Reduviidae (Assassin-bugs).

Reduvius personatus, Linn.

Sinea diadema, Fab.

Acholla multispinosa, De G.

Nabidae (Damsel-bugs).

Reduviolus rufusculus, Reut.

Clinocoridae (Bed-bug Family).

Cimex lectularius, Linn.

Miridae (Leaf-bugs).

Adelphocoris rapidus, Say.

Miris dolabratus, Linn.

Phytocoris pallicornis, Reut.

Neurocolpus nubilus, Say.

Lygus pratensis, Linn.

Poecilocapsus lineatus, Fab.

Lopidea media, Say.

Plagiognathus obscurus, Uhl.

Belostomatidae (Giant Water-bugs).

Benacus griseus, Say.

Amorgius americanus, Leidy.

(Belostoma, Auctt.)

Belostoma fluminea, Say (Zaitha, Auctt.).

Nepidae (Water-scorpions).

Nepa apiculata, Uhl.

Ranatra fusca, P.B.

Notonectidae (Back-swimmers).

Notonecta undulata, Say. 


\section{INSECTS AND THEIR ALLIES}

Corixidae (Water-boatmen).

Corixa sp.

\section{Order NEUROPTERA.}

With the exception of the first four species, which were named by the writer, the determinations were furnished by Mr. Nathan Banks.

\section{Sialidae.}

Corydalis cornuta, Linn.

Chauliodes pectinicornis, Linn.

Sialis infumata, Newm.

\section{Hemerobiidae.}

Polystoechotes punctatus, Fab.

Hemerobius humuli, Linn.

Hemerobius stigmaterus, Fitch.

Chrysopidae (Lace-winged Flies)

Chrysopa rufilabris, Burm.

$$
\text { “ ypsilon, Fitch. }
$$

\section{Order TRICHOPTERA (Caddis-Flies).}

Practically no collections have been made in this order. A few specimens were sent to Mr. Banks, who determined them as follows:

\section{Phryganeidae.}

Phryganea cinerea, Walk.

Neuronia concatenata, Walk.

\section{Limnephilidae.}

Limnephilus submonilifer, Walk.

Pycnopsyche guttifer, Walk. 
NATURAL HISTORY, TORONTO REGION

\section{Hydropsychidae.}

Hydropsyche scalaris, Hag.

\section{Order COLEOPTERA.}

Cicindelidae (Tiger-beetles).

Cicindela scutellaris lecontei, Hald.

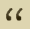
sex-guttata, Fab.

“ purpurea, Oliv.

“ vulgaris, Say.

" repanda, Dej.

“ 12-guttata, Dej.

“ hirticollis, Say.

“ punctulata, Fab.

Carabidae (Ground-beetles).

Omophron robustum, Horn.

“ americanum, Dej.

“ tessellatum, Say.

Cychrus lecontei, Dej.

Carabus sylvosus, Say.

Calosoma scrutator, Fab.

" frigidum, Kirby.

" willcoxi, Lec.

" calidum, Fab.

Elaphrus ruscarius, Say.

Loricera coerulescens, Linn.

Notiophilus aeneus, Hbst.

Nebria pallipes, Say.

Scarites subterraneus, Fab.

Dyschirius aeneolus, Lec. 


\section{INSECTS AND THEIR ALLIES}

Carabidae (Ground-beetles)-(Continued).

Dyschirius longulus, Lec.

66

sphaericollis, Say.

" integer, Lec.

Clivina impressifrons, Lec.

Schizogenius lineolatus, Say.

“ ferrugineus, Putz.

Nomius pygmaeus, Dej.

Bembidium carinula, Chd.

"

"6

6

"6

66

《6

66

66

"6

66

66 nitidulum, Dej.

nitidum, Kirby.

nigrum, Say.

rupestre, Dej.

cordatum, Lec.

variegatum, Say.

assimile, Gyll.

quadrimaculatum, Linn.

oblongulum, Mann.

postfasciatum, Hamilton. muscicola.

Tachys scitulus, Lec.

" nanus, Gyll.

" flavicauda, Say.

" incurvus, Say.

Patrobus longicornis, Say.

Trechus chalybeus, Mann.

Pterostichus honestus, Say.

"

coracinus, Newm.

“ stygicus, Say.

“ sayi, Brullé.

313 


\section{NATURAL HISTORY, TORONTO REGION}

Carabidae (Ground-beetles)-(Continued).

Pterostichus lucublandus, Say.

“ luctuosus, Dej.

" corvinus, Dej.

" luczotii, Dej.

“ erythropus, Dej.

" patruelis, Dej.

" femoralis, Kirby.

Amara avida, Say.

" arenaria, Lec.

" exarata, Dej.

" pallipes, Kirbr.

" impuneticollis, Say.

" interstitialis, Dej.

" obesa, Say.

“ remotestriata, Dej.

Diplochila laticollis, Lec.

" " major, Lec.

" impressicollis, Dej.

Dicaelus teter, Bon.

Badister pulchellus, Lec.

Calathus gregarius, Say.

" impunctatus, Say.

Platynus hypolithus, Say.

$\begin{array}{ll}\text { “ } & \text { decens, Say. } \\ \text { “ } & \text { sinuatus, Dej. } \\ \text { cincticollis, Say. } \\ \text { “ } & \text { dectensicollis, Say. } \\ \text { “ } & \text { auchomenoides, Rand. }\end{array}$




\section{INSECTS AND THEIR ALLIES}

Carabidae (Ground-beetles)-(Continued).

Platynus pusillus, Lec.

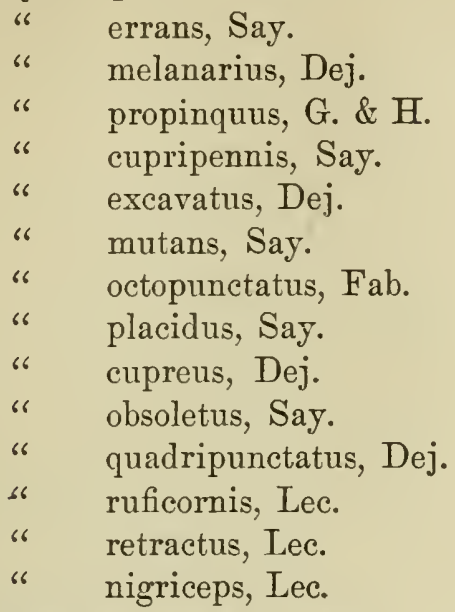

Olisthopus parmatus, Say.

$$
\text { " micans, Lec. }
$$

Atranus pubescens, Dej.

Casnonia pennsylvanica, Linn.

Galerita janus, Fab.

Lebia grandis, Heutz.

" atriventris, Say.

" tricolor, Say.

"viridis, Say.

" pumila, Dej.

" ornata, Say.

" scapularis, Dej.

Dromius piceus, Dej.

Apristus cordicollis, Lec. 


\section{NATURAL HISTORY, TORONTO REGION}

Carabidae (Ground-beetles)-(Continued).

Blechrus nigrinus, Mann.

Metabletus americanus, Dej.

Axinopalpus biplagiatus, Dej.

Cymindis americana, Dej.

" pilosa, Say.

Brachynus perplexus, Dej.

" medius, Harr.

“ fumans, Fab.

Chlaenius erythropus, Germ.

" sericeus, Forst.

" hemoralis, Say.

" tricolor, Dej.

" pennsylvanicus, Say.

" niger, Rand.

" tomentosus, Say.

Brachylobius lithophilus, Say.

Geopinus incrassatus, Dej.

Agonoderus lineola, Fab.

" pallipes, Fab.

" partiarius, Say.

Harpalus vulpeculus, Say.

" erraticus, Say.

" viridiaeneus, Beauv.

" caliginosus, Fab.

" pennsylvanicus, De G.

" pleuriticus, Kirby.

" basilaris, Kirby.

Selenophorus opalinus, Lec.

Stenolophus fuliginosus, Dej. 


\section{INSECTS AND THEIR ALLIES}

Carabidae (Ground-beetles)-(Continued).

Stenolophus conjunctus, Say.

Bradycellus rupestris, Say.

Tachycellus nigrinus, Dej.

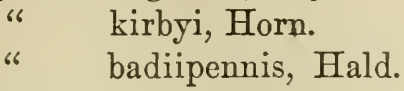

Anisodactylus rusticus, Dej.

$\begin{array}{ll}\text { “ } & \text { carbonarius, Say. } \\ \text { harrisii, Lec. } \\ \text { “ } & \text { discoideus, Dej. } \\ \text { baltimorensis, Say. } & \text { verticalis, Lec. } \\ \text { “ } & \text { interstitialis. Say. }\end{array}$

Haliplidae (Haliplids).

Haliplus fasciatus, Aubé.

$$
\begin{array}{ll}
\text { " triopsis, Say. } \\
\text { “ } & \text { cribrarius, Lec. } \\
& \text { ruficollis, Deg. }
\end{array}
$$

Cnemidotus 12-punctatus, Say.

Dytiscidae (Diving-beetles).

Laccophilus maculosus, Germ.

Bidessus affinis, Say.

Coelambus inaequalis, Fab.

" turbidus, Lec.

“ impressopunctatus, Sch.

Hydroporus pulcher, Lec.

$\begin{array}{ll}\text { “ } & \text { undulatus, Say. } \\ \text { “ } & \text { consimilis, Lec. } \\ \text { “triatopunctatus, Melsh. } & \text { tartaricus, Lec. } \\ & 317\end{array}$




\section{NATURAL HISTORY, TORONTO REGION}

Dytiscidae (Diving-beetles)-(Continued).

Hydroporus dichrous, Melsh.

“ modestus, Aubé.

Ilybius biguttulus, Germ.

Coptotomus interrogatus, Fab.

Agabus seriatus, Say.

“ punctulatus, Aubé.

“ obsoletus, Lec.

“ erythropterus, Say.

Rhantus binotatus, Harr.

Colymbetes sculptilis, Harr.

Hydaticus piceus, Lec.

Dytiscus fasciventris, Say.

“ hybridus, Aubé.

“ verticalis, Say.

" harrisii, Kirby.

Acilius semisulcatus, Aubé.

Thermonectes basilaris, Harr.

Graphoderes fascicollis, Harr.

Cybister fimbriolatus, Say.

Gyrinidae (Whirligig-beetles).

Gyrinus dichrous, Lec.

“ ventralis, Kirby.

Dineutes assimilis, Aubé.

Hydrophilidae (Waver-scavenger beetles).

Helophorus lacustris, Lec.

angustulus, Mann.

“ lineatus, Say.

" tuberculatus, Gyll.

Hydrochus excavatus, Lec. 


\section{INSECTS AND THEIR ALLIES}

Hydrophilidae (Waver-scavenger beetles)-(Continued).

Hydrophilus triangularis, Say.

Tropisternus nimbatus, Say.

66

glaber Hbst.

Hydrocharis obtusatus, Say.

Berosus striatus, Say.

Laccobius agilis, Rand.

Philhydrus ochraceus, Mels. perplexus, Lec.

Hydrobius globosus, Say.

" fascipes, Linn.

" digestus, Lec.

“ subcupreus, Say.

Sphaeridium scarabaeoides, Linn.

Cercyon melanocephalum, Linn.

" praetextatum, Say.

" unipunctatum, Linn.

Cryptopleurum vagans, Lec.

Silphidae (Carrion-beetles).

Necrophorus americanus, Oliv.

sayi, Lapp.

“ orbicollis, Say.

" marginatus, Fab.

“ pustulatus, Hersh.

“ vespilloides, Hbst.

“ tomentosus, Web.

Silpha surinamensis, Fab.

" lapponica, Hbst.

" inaequalis, Fab.

“ noveboracensis, Forst. 
Silphidae (Carrion-beetles)-(Continued).

Silpha americana, Linn.

Choleva basilaris, Say.

" clavicornis, Lec.

Ptomaphagus consobrinus, Lec.

parasitus, Lec.

“ brachyderus, Lec.

Liodes globosa, Lec.

" obsoleta, Horn.

" basalis, Lec.

Agathidium oniscoides, Beauv.

Scydmaenidae.

Scydmaenus perforatus, Schaurn.

$\begin{array}{ll}\text { “ } & \text { fossiger, Lec. } \\ \text { clavipes, Say. } \\ \text { “ } & \text { consobrinus, Lec. } \\ \text { " } & \text { bicolor, Lec. } \\ \text { salinator, Lec. }\end{array}$

Pselaphidae.

Ceophyllus monilis, Lec.

Pilopius saginatus, Csy.

Cedius ziegleri, Lec.

Ctenistes piceus, Lec.

Decarthron abnorme, Lec.

" strenuum, Brend.

Batrisus globosus, Lec.

" lineaticollis, Aubé.

Bryaxis brendelii, Horn.

" rubicunda, Aubé.

“ puncticollis, Lec. 


\section{Pselaphidae-(Continued).}

Bryaxis propinqua, Lec.

Staphylinidae (Rove-beetles).

Falagria dissecta, Er.

“ venustula, Er.

Lomechusa cava, Lec.

Tachyusa cavicollis, Lec.

Aleochara lata, Grav.

$$
\text { “ } \quad \text { bimaculata, Grav. }
$$

Oxypoda sagulata, Er.

Gyrophaena corruscula, Er.

$$
\text { " socia, Er. }
$$

Gymnusa brevicollis, Grav.

Heterothops fumigatns, Lec.

Quedius fulgidus, Fav.

" capucinus, Grav.

“ vernix, Lec.

Listotrophus cingulatus, Grav.

“ capitatus, Bland.

Creophilus villosus, Grav.

Staphylinus badipes, Lec.

vulpinus, Nordm.

“ maculosus, Grav.

“ mysticus, Er.

" fossator, Grav.

" cinnamopterus, Grav.

“ violaceus, Grav.

" viridans, Horn.

Ocypus ater, Grav. 
Staphylinidae (Rove-beetles)-(Continued).

Philonthus aeneus, Rossi.

" laetulus, Say.

“ palliatus, Grav.

“ varians, Payk.

“ longicornis, Steph.

“ discoideus, Grav.

“ lomatus, Er.

“ aequalis, Horn.

" cyanipennis, Fab.

" sordidus, Grav.

Actobius sobrinus, Er.

" paederoides, Lec.

Xantholinus cephalus, Say.

" obscurus, Er.

Diochus schaumii, Kraatz.

Stenus bipunctatus, Er.

$$
\begin{array}{ll}
\text { “ } & \text { colon, Say. } \\
\text { juno, Fab. } \\
\text { “ } \\
\text { colonus, Er. } \\
\text { " mammops, Csy. } \\
\text { “ croceatus, Csy. } \\
\text { annularis, Er. }
\end{array}
$$

Cryptobium bicolor, Grav. "

$$
\text { “ sellatum, Lec. }
$$

Lathrobium punctulatım, Lec.

" simplex, Lec.

“ parcum, Lec.

“ ventrale, Lec. 


\section{INSECTS AND THEIR ALLIES}

Staphylinidae (Rove-beetles)-(Continued).

Scopaeus exiguus, Er.

Stilicus dentatus, Say.

" biarmatus, Lec.

Lithocharis confluens, Say.

Paederus littorarius, Grav.

Sunius prolixus, Er.

" binotatus, Say.

" longiusculus, Mann.

Tachinus memnonius, Grav.

" repandus, Horn.

" flavipennis, Dej.

" luridus, Er.

" fimbriatus, Grav.

Tachyporus jocosus, Say.

" chrysomelinus, Linn.

Erchomus ventriculus, Say.

Conosoma crassum, Grav.

" pubescens, Payk.

Boletobius cingulatus, Mann.

" intrusus, Horn.

" anticus, Horn.

" cinctus, Grav.

Olisthaerus substriatus, Gyll.

Oxyporus femoralis, Grav.

" vittatus, Grav.

Bledius fumatus, Lec.

" analis, Lec.

" pleuralis, Lec. 


\section{NATURAL HISTORY, TORONTO REGION}

Staphylinidae (Rove-beetles)-(Continued).

Platystethus americanus, Er.

Oxytelus rugosus, Grav.

" convergens, Lec.

Apocellus sphaericollis, Say.

Geodromicus brunneus, Say.

Homalium rufipes, Faurv.

Anthobium convexum, Fauv.

Micropeplus cribratus, Lec.

\section{Trichopterygidae.}

Trichopteryx haldemanni, Lec.

\section{Scaphidiidae.}

Scaphidium quadrignttatum, Say.

Scaphisoma convexum, Say.

$$
\text { “ suturale, Lec. }
$$

\section{Phalacridae.}

Phalacrus consimilis, Marsh.

" nitidus, Melsh.

\section{Corylophidae.}

Sacium fasciatum, Say.

" lnnatum, Lec.

Corylophus truncatus, Lee.

Sericoderus obscurus, Lec.

Orthoperus scutellaris, Lec.

Coccinellidae (Ladybirds).

Anisosticta strigata, Thunb.

Megilla maculata, De G.

Hippodamia convergens, Guér.

“ 13-punctata, Linn.

“ parenthesis, Say. 


\section{INSECTS AND THEIR ALLIES}

Coccinellidae (Ladybirds) -(Continued).

Coccinella trifasciata, Linn.

66

novemnotata, Hbst.

" transversoguttata, Fab.

" sanguinea, Linn.

Adalia bipunctata, Linn.

Harmonia picta, Rand.

Mysia pullata, Say.

Anatis 15-punctata, Oliv.

Psyllobora 20-maculata, Say.

Chilocorus bivulnerus, Muls.

Brachyacantha dentipes, Fab.

"

66 ursina, Fab.

" 10-pustulata, Melsh.

Hyperaspis undulata, Say.

" signata, Oliv.

" proba, Say.

“ bigeminata, Rand.

Scymnus puncticollis, Lec.

" marginicollis, Mann.

“ tenebrosus, Muls.

" lacustris, Lec.

Coccidula lepida, Lec.

Endomychidae (Fungus-beetles).

Phymaphora pulchella, Newm.

Lycoperdina ferruginea, Lec.

Aphorista vittata, Fab.

Mycetina perpulchra, Newm.

Endomychus biguttatus, Say. 


\section{NATURAL HISTORY, TORONTO REGION}

\section{Erotylidae.}

Languria mozardi, Latr.

Dacne 4-maculata, Say.

Mycotretus pulchra, Say.

Tritoma thoracica, Say.

" flavicollis, Lac.

\section{Colydiidae.}

Ditoma quadriguttata, Say.

Colydium lineola, Say.

Cerylon castaneum, Say.

\section{Cucujidae.}

Silvanus surinamensis, Linn.

" bidentatus, Fab.

" imbellis, Lec.

Catogenus rufus, Fab.

Pediacus depressus, Hbst.

Cucujus clavipes, Fab.

Laemophlaeus biguttatus, Say.

fasciatus, Melsh.

“ adustus, Lec.

" testaceus, Fab.

Dendrophagus glaber, Lec.

Brontes dubius, Fab.

Telephanus velox, Hald.

\section{Cryptophagidae.}

Telmatophilus americanus, Lec.

Tomarus pulchellus, Lec.

Atomaria ephippiata, Zimm.

" ovalis, Csy. 


\section{INSECTS AND THEIR ALLIES}

\section{Mycetophagidae.}

Mycetophagus punctatus, Say.

$$
\text { " flexuosus, Say. }
$$

Triphyllus humeralis, Kirby.

Litargus 6-punctatus, Say.

Dermestidae (Dermestids).

Byturus unicolor, Say.

Dermestes caninus, Germ.

“ lardarius, Linn.

$\Lambda$ ttagenus piceus, Oliv.

Trigoderma ornatum, Say.

Anthrenus scrophulariae, Linn.

" musaeorum, Linn.

Orphilus glabratus, Fab.

\section{Histeridae.}

Hololepta fossularis, Say.

Hister merdarius, Hoffm.

" interruptus, Beauv.

" foedatus, Lec.

“ bimaculatus, Linn.

" subrotundus, Say.

“ lecontei, Mars.

" parallelus, Say.

Paromalus gilensis, Lec.

"

estriatus, Lec.

Saprinus fraternus, Say.

“ patruelis, Lec.

Plegaderus sayi, Mars.

Aeletes politus, Lec. 


\section{Nitidulidae.}

Cercus pennatus, Mur.

Carpophilus niger, Say.

brachypterus, Say.

Colastus semitectus, Say.

" truncatus, Rand.

Epuraea rufa, Say.

" avara, Rand.

Nitidula bipustulata, Linn.

" rufipes, Linn.

Stelidota 8-maculata, Say.

Prometopia 6-maculata, Say.

Phenolia grossa, Fab.

Omosita colon, Fab.

Cychramus adustus, Er.

Cryptarcha ampla, Er.

Ips obtusus, Say.

"fasciatus, Oliv.

" sanguinolentus, Oliv.

Rhizophagus sculpturatus, Mann. remotus, Lec.

\section{Latridiidae.}

Stephostethus liratus, Lec.

Corticaria serricollis, Lec.

“ serrata, Payk.

“ elongata, Hum.

“ angularis, Lec.

" cavicollis. Mann.

“ pumila, Lec.

" picta, Lec. 


\section{INSECTS AND THEIR ALLIES}

\section{Trogositidae.}

Tenebrioides corticalis, Melsh.

" $"$ castanea, Melsh.

Calitys scabra, Thunb.

Grynocharis 4-lineata, Melsh.

Thymalus fulgidus, Er.

Byrrhidae (Pill-beetles).

Cytilus sericeus, Forst.

Byrrhus americanus, Lec.

Limnichus punctatus, Lec.

\section{Georhyssidae.}

Georhyssus pusillus, Lec.

\section{Parnidae.}

Dryops fastigiatus, Say.

Elmis 4-notatus, Say.

Stenelmis crenatus, Say.

Macronychus glabratus, Say.

\section{Heteroceridae.}

Heterocerus substriatus, Kies.

\section{Dascyllidae.}

Prionocyphon limbatus, Lec.

Cyphon ruficollis, Say.

" obscurus, Guér.

Elateridae (Click-beetles, Elaters).

Tharops ruficornis, Say.

Deltometopus amoenicornis, Say.

Dromaeolus striatus, Lec.

Fornax calceatus, Say. 


\section{NATURAL HISTORY, TORONTO REGION}

Elateridae (Click-beetles, Elaters)-(Continued).

Adelocera discoidea, Web.

" aurorata, Lec.

" obtecta, Say.

" brevicornis, Lec.

Alaus oculatus, Linn.

" myops, Fab.

Cardiophorus convexus, Say. "6

cardisce, Say.

" convexulus, Lec.

" gagates, Er.

Cryptohypnus abbreviatus, Say.

"6

delumbis, Horn.

" exiguus, Rand.

Oedostethus femoralis, Lec.

Monocepidius auritus, Hbst.

Elater hepaticus, Melsh.

" pedalis, Germ.

" pullus, Germ.

" nigricollis, Hbst.

" linteus, Say.

" discoideus, Fab.

" semicinctus, Rand.

" rubricus, Say.

" apicatus, Say.

" obliquus, Say.

Drasterius elegans, Fab.

Megapenthes rogersii, Horn.

Ludius abruptus, Say.

Agriotes mancus, Say. 


\section{INSECTS AND THEIR ALLIES}

Elateridae (Click-beetles, Elaters)-(Continued).

Agriotes stabilis, Lec.

" fucosus, Lec.

Dolopius lateralis, Esch.

Melanotus fissilis, Say.

6

communis, Gyll.

" sagittarius, Lec.

" paradoxus, ilelsh.

Limonius aurifer, Lec.

" confusus, Lec.

" agonus, Say.

Campylus denticornis, Kirby.

Athous cucullatus, Say.

" scapularis, Say.

Oestodes tenuicollis, Rand.

Sericosomus silaceus, Say.

Corymbites cylindriformis, Hbst.

"

spinosus, Lec.

" tarsalis, Melsh.

" sulcicollis, Say.

" fallax, Say.

" medianus, Germ.

" triundulatus, Rand.

" hamatus, Say.

" propola, Lec.

" hieroglyphicus, Say.

" cruciatus, Linn.

" aratus, Lec.

" metallicus Payk.

" inflatus, Say. 


\section{NATURAL HISTORY, TORONTO REGION}

Elateridae (Click-beetles, Elaters)-(Continued).

Corymbites rotundicollis, Say.

Asaphes decoloratus, Say.

" memnonius, Hbst.

\section{Throscidae.}

Throscus constrictor, Say.

" chevrolati, Bonv.

Buprestidae (Metallic Wood-borers).

Chalcophora virginiensis, Drury.

Dicerca divaricata, Say.

" tenebrosa, Kirby.

Poecilonota cyanipes, Say.

Buprestis lineata, Fab.

" consularis, Gory.

" maculiventris, Say.

" fasciata, Fab.

" striata, Fab.

Melanophila longipes, Say.

" fulvoguttata, Harr.

Anthaxia viridifrons, Lap.

" viridicornis, Say.

Chrysobothris femorata, Fab.

" dentipes, Germ.

Agrilus ruficollis, Fab.

$\begin{array}{ll}\text { " } & \text { otiosus, Say. } \\ \text { " } & \text { anxineatus, Wory. } \\ \text { " } & \text { politus, Say. } \\ \text { " couesii, Lec. }\end{array}$




\section{INSECTS AND THEIR ALLIES}

Buprestidae (Metallic Wood-borers)-(Continued).

Brachys ovata, Web.

$$
\text { " aerosa, Melsh. }
$$

Lampyridae (Fire-flies, etc.).

Calopteron terminale, Say.

" reticulatum, Fab.

Eros simplicipes, Mann.

" aurora, Hbst.

" humeralis, Fab.

Lucidota atra, Fab.

Ellychnia corrusca, Linn.

Pyropyga nigricans, Say.

“ decipiens, Harr.

Pyractomena angulata, Say.

Photinus ardens, Lec.

" pyralis, Linn.

Photuris pennsylvanica, De G.

Chauliognathus pennsylvanicus, De G.

Podabrus tricostatus, Say.

" rugulosus, Lec.

" diadema, Fab.

" punctatus, Lec.

Silis percomis, Say.

Telephorus fraxini, Say.

" carolinus, Fab.

" lineola, Fab.

" scitulus, Say.

" rotundicollis, Say.

" tuberculatus, Lec.

" bilineatus, Say. 


\section{NATURAL HISTORY, TORONTO REGION}

\section{Malachidae.}

Collops 4-maculatus, Fab.

" vittatus, Say.

Attalus terminalis, Er.

" morulus, Lec.

Cleridae (Checkered Beetles).

Cymatodera bicolor, Say. " inornata, Say.

Trichodes nuttalli, Kirby.

Clerus nigriventris, Lec.

Thanasimus trifasciatus, Say.

"6

dubius, Fab.

Thaneroclerus sanguineus, Say.

Hydnocera pedalis, Lec.

"6

$$
\text { verticalis, Say. }
$$

Phyllobaenus dislocatus, Say.

Chariessa pilosa, Forst.

Laricobius erichsoni, Rosen.

Necrobia rufipes, Fab.

66

$$
\text { violaceus, Linn. }
$$

Ptinidae (Death-watch Family).

Ptinus fur, Linn.

" brunneus, Duft.

Eucrada humeralis, Melsh.

Ernobius mollis, Linn.

Xestobium tessellatum, Fab.

Sitodrepa panicea, Linn.

Hadrobregmus errans, Melsh.

"6

pumilio, Lec.

Trichodesma gibbosa, Say.

334 


\section{INSECTS AND THEIR ALLIES}

Ptinidae (Death-watch Family)-(Continued).

Vrilletta convexa, Lec.

Xyletinus lugubris, Lec.

Dorcatoma setulosum, Lec.

Endecatomus rugosus, Rand.

Bostrychus truncaticollis, Lec.

Amphicerus bicaudatus, Say.

Lyctus striatus, Melsh.

\section{Cupesidae.}

Cupes capitata, Fab.

Cioidae.

Cis fuscipes, Mellié.

Ennearthron thoracicornis, Ziegl.

\section{Sphindidae.}

Sphindus americanus, Lec.

Lucanidae (Stag-beetles).

Lucanus dama, Thunb. " placidus, Say.

Dorcus parallelus, Say.

Platycerus quercus, Web. depressus, Lec.

Ceruchus piceus, Web.

Scarabaeidae (Dung-beetles, Chafers, etc.).

Copris anaglypticus, Say.

Onthophagus hecate, Panz.

janus, Panz.

Aegialia conferta, Horn. Ataenius gracilis, Melsh. Dialytes striatulus, Say. 
Scarabaeidae (Dung-beetles, Chafers, etc.)-(Continued).

Dialytes truncatus, Melsh.

Aphodius fossor, Linn.

" fimetarius, Linn.

" ruricola, Melsh.

" granarius, Linn.

" vittatus, Say.

“ inquinatus, Hbst.

“ leopardus, Horn.

" pondromus, Brahm.

Geotrupes splendidus, Fab.

":

egeriei, Germ.

" blackburnii, Fab.

Trox erinaceus, Lec.

" unistriatus, Beauv.

" aequalis, Say.

" scaber, Linn.

Hoplia trifasciata, Say.

" " tristis, Melsh.

Dichelonycha elongata, Fab.

$\begin{array}{ll}\text { " } & \text { subvittata, Lec. } \\ \text { " canadensis, Horn. } \\ \text { albicollis, Burm. }\end{array}$

Serica vespertina, Gyll.

" sericea, Ill.

Macrodactylus subspinosus, Fab.

Diplotaxis sordida, Say.

" liberta, Germ.

Lachnosterna fusca, Fröh.

"6

marginalis, Lee.

336 


\section{INSECTS AND THEIR ALLIES}

Scarabaeidae (Dung-beetles, Chafers, etc.)-(Continued).

Lachnosterna hirsuta, Knoch.

"s

crenulata, Fröh.

Cotalpa lanigera, Linn.

Aphonus tridentatus, Say.

Xyloryctes satyrus, Fab.

Euphoria inda, Linn.

Osmoderma eremicola, Knoch.

"6

scabra, Beauv.

Trichius affinis, Gory.

\section{Spondylidae.}

Parandra brunnea, Fab.

Cerambycidae (Longicorn beetles).

Orthosoma brunneum, Forst.

Tragosoma harrisii, Lec.

Asemum moestum, Hald.

Criocephalus agrestis, Kirby.

Tetropium cinnamopterum, Kirby.

Hylotrupes ligneus, Fab.

Phymatodes amoenus, Say.

Callidium antennatum, Newm.

Romaleum atomarium, Drury.

" rufulum, Hald.

" taeniatum, Lec.

Molorchus bimaculatus, Say.

Callimoxys sanguinicollis, Oliv.

Batyle suturalis, Say.

Cyllene robiniae, Forst.

Plagionotus speciosus, Say.

Calloides nobius, Say. 
Cerambycidae (Longicorn beetles)-(Continued).

Arhopalus fulminans, Fab.

Xylotrechus quadrimaculatus, Hald.

“ undulatus, Say.

Neoclytus muricatulus, Kirby.

" erythrocephalus, Fab.

" longipes, Kirby.

Clytanthus ruricola, Oliv.

Microclytus gazellula, Hald.

Cyrtophorus verrucosus, Oliv.

Euderces picipes, Fab.

Encyclops caeruleus, Say.

Rhagium lineatum, Oliv.

Toxotus vittiger, Rand.

Pachyta monticola, Rand.

Acmaeops proteus, Kirby.

Gaurotes cyanipennis, Say.

Typocerus velutinus, Oliv.

Leptura propinqua, Bland.

" plebeja, Rand.

" subhamata, Rand.

" lineola, Say.

" capitata, Newm.

" americana, Hald.

" haematites, Nerrm.

“ subargentata, Kirby.

“ zebra, Oliv.

" canadensis, Fab.

“ vagans, Oliv.

“ chrysocoma, Kirby. 


\section{INSECTS AND THEIR ALLIES}

Cerambycidae (Longicorn beetles)-(Continued)

Leptura proxima, Say.

" biforis, Newm.

" vittata, Germ.

" pubera, Say.

" ruficollis, Say.

" " sphaericollis, Say.

" vibex, Newm.

" mutabilis, Newm.

Psenocerus supernotatus, Say. Monohammus titillator, Fab. 6 scutellatus, Say. " confüsor, Kirby.

Goes pulchra, Hald.

" debilis, Lec.

" pulverulenta, Hald.

" oculata, Lec.

Leptostylus macula, Say.

Lepturges signatus, Lec.

Hyperplatys aspersus, Say.

Acanthocinus obsoletus, Oliv.

Pogonocherus crinitus, Lec.

Eupogonius tomentosus, Hald.

" subarmatus, Lec.

Saperda obliqua, Say.

$\begin{array}{ll}\text { " } & \text { calcarata, Say. } \\ \text { vestita, Say. } \\ \text { "tridentata, Oliv. } \\ \text { " } & \text { puncticollis, Say. } \\ \text { moesta, Lec. }\end{array}$




\section{NATURAL HISTORY, TORONTO REGION}

Cerambycidae (Longicorn beetles)-(Continued).

Saperda concolor, Lec.

Oberea bimaculata, Oliv.

" " tripunctata, Fab.

" ocellata, Hald.

Tetraopes tetraophthalmus, Forst.

Chrysomelidae (Leaf-beetles).

Donacia hypoleuca, Lac.

“ proxima, Kirby.

" subtilis, Kunze.

" emarginata, Kirby.

" rufa, Say.

Haemonia nigricornis, Kirby.

Orsodachna atra, Ahr.

"6

66

66

" childreni, Kirby.

" luctuosa, Lac. •

" tricolor, Melsh.

Zeugophora scutellaris, Suffr.

$\begin{array}{ll}\text { “ } & \text { abnormis, Lec. } \\ \text { “ } & \text { puberula, Cr. } \\ \text { “ } & \text { varians, Cr. } \\ & \text { kirbyi, Baly. }\end{array}$

Syneta ferruginea, Germ.

Lema trilineata, Oliv.

Crioceris asparagi, Linn.

" 12-punctatus, Linn.

Anomoea laticlavia, Forst.

Coscinoptera dominicana, Fab.

Babia 4-guttata, Oliv.

Chlamys plicata. Fab. 


\section{INSECTS AND THEIR ALLIES}

Chrysomelidae (Leaf-beetles)-(Continued). :

Exema gibber, Oliv.

Bassareus mammifer, Newm.

66

66

66
«

"6 pretiosus, Melsh.

luteipennis, Melsh.

sellatus, Melsh.

Cryptocephalus 4-maculatus, Say.

"6

66

"6 quadruplex, Newm.

venustus, Fab.

mutabilis, Melsh.

Pachybrachys othonus, Say.

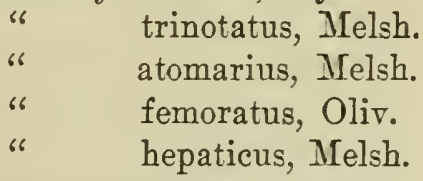

Monachus saponatus, Fab.

Diachus auratus, Fab.

" catarius, Suffr.

Xanthonia 10-notata, Say.

"6

$$
\text { stevensii, Baly. }
$$

Adoxus vitis, Linn.

Glyptoscelis pubescens, Fab.

Chrysochus auratus, Fab.

Paria 6-notata, Say.

Graphops pubescens, Melsh.

$$
\text { marcassita, Cr. }
$$

Chrysodina globosa, Say.

Colaspis brunnea costipennis, Dej.

" praetexta, Say.

" tristis puncticollis, Say. 


\section{NATURAL HISTORY, TORONTO REGION}

Chrysomelidae (Leaf-beetles)-(Continued).

Prasocuris varipes, Lec.

Labidomera clivicollis, Kirby.

Leptinotarsa 10-lineata, Say.

Calligrapha similis, Rog.

$\begin{array}{ll}\text { “ } & \text { elegans, Oliv. } \\ \text { " scalaris, Lec. } \\ \text { multipunctata bigsbyana, Say. }\end{array}$

Plagiodera cochleariae, Gyll.

“ - viridis, Melsh.

Gastroidea polygoni, Linn.

Lina lapponica, Linn.

" scripta, Fab.

Phyllodecta vulgatissima, Linn.

Cerotoma caminea, Fab.

Phyllobrotica decorata, Say.

" discoidea, Fab.

Luperus meraea, Say.

Diabrotica 12-punctata, Oliv.

“ vittata, Fab.

Trirhabda tomentosa canadensis, Kirby.

Adimonia cavicollis, Lec.

Galeruca sagittariae, Gyll.

Oedionychis quercata limbalis, Melsh.

Disonycha alternata, Ill.

"6

pennsylvanica, Ill.

" triangularis, Say.

" collaris, Fab.

Haltica bimarginata, Say. 


\section{INSECTS AND THEIR ALLIES}

Chrysomelidae (Leaf-beetles)-(Continued).

Haltica carinata, Germ.

" ignita, Ill.

Crepidodera helxines, Linn. " cucumeris, Harr.

Orthaltica copalina, Fab. Systena hudsonias, Forst.

" frontalis, Fab.

" marginalis, Ill.

Longitarsus testaceus, Lec.

Phyllotreta vittata, Fab. " bipustulata, Fab.

Mantura floridana, Cr.

Chaetocnema denticulata, Ill.

"6

parcepunctata, $\mathrm{Cr}$.

Dibolia aerea, Mrelsh.

Psylliodes punctulata, Melsh.

Microrhopala porcata, Melsh.

Odontota horni, Smith.

" nervosa, Punz.

Coptocycla aurichalcea, Fab.

Bruchidae (Pea-weevil Family).

Bruchus pisi, Linn.

" cruentatus, Horn.

Tenebrionidae (Darkling beetles).

Phellopsis obcordata, Kirby.

Nyctobates pennsylvanicus, De G.

Upis ceramboides, Linn.

Scotobates calcaratus, Fab.

Xylopinus saperdioides, Oliv. 
Tenebrionidae (Darkling beetles)-(Continued).

Tenebrio obscurus, Fab.

" molitor, Linn.

" tenebrioides, Beauv.

Blapstinus metallicus, Fab.

Dioedus punctatus, Lec.

Gnathocerus cornutus, Fab.

Uloma impressa, Melsh.

Paratenetus punctatus, Sol. " fuscus, Lec.

Diaperis hydni, Fab.

Hoplocephala bicornis, Oliv.

Platydema excavatum, Say.

“ ruficorne, Sturm.

" americanum, Lap.

Hypophloeus parallelus, Melsh.

Bolitotherus bifurcus, Fab.

Boletophagus depressus, Rand.

\section{Cistelidae.}

Hymenorus niger, Melsh.

Isomira quadristriata, Coup.

Mycetochares fraterna, Say.

Androchirus erythropus, Kirby.

Lagriidae.

Arthromacra aenea, Say.

Melandryidae.

Tetratoma truncorum, Lec.

Penthe obliquata, Fab.

" pimelia, Fab.

Synchroa punctata, Newm.

344 


\section{INSECTS AND THEIR ALLIES}

Melandryidae-(Continued).

Prothalpia undata, Lec.

Melandrya striata, Say.

Enchodes sericea, Hald.

Hypulus simulator, Newm.

Dircaea liturata, Lec.

Eustrophus bicolor, Say.

" bifasciatus, Say.

" tomentosus, Say.

Hallomenus punctulatus, Lec.

Orchesia castanea, Melsh.

Canifa pallipes, Melsh.

Mycterus scaber, Hald.

Pythidae.

Pytho americanus, Kirby.

Rhinosimus viridiaeneus, Rand.

Oedemeridae.

Nacerdes melanura, Linn.

Asclera ruficollis, Say.

" puncticollis, Say.

Cephaloidae.

Cephaloon lepturides, Newm.

\section{Mordellidae.}

Anaspis flavipennis, Hald.

" rufa, Say.

Tomoxia bidentata, Say.

Mordella melaena, Germ.

"6 scutellaris, Fab.

" marginata, Melsh.

" serval, Say. 


\section{NATURAL HISTORY, TORONTO REGION}

Mordellidae (Continued).

Mordellistena scapularis, Say.

66 comata, Lec.

" tosta, Lec.

" nigricans, Melsh.

" fuscata, Melsh.

\section{Anthicidae.}

Stereopalpus badiipennis, Lec.

Corphyra terminalis, Say.

“ fulvipes, Newm.

Macratria murina, Fab.

Notoxus anchora, Hentz.

Anthicus obscurus, Laf.

" cinctus, Say.

" scabriceps, Lec.

" cervinus, Laf.

" melancholicus, Laf.

\section{Pyrochroidae.}

Schizotus cervicalis, Newm.

Dendroides canadensis, Lat. " concolor, Newm.

" bicolor, Newm.

Meloidae (Blister-beetles)

Meloe niger, Kirby.

" angusticollis, Say.

" americanus, Leach.

Macrobasis unicolor, Kirby.

Epicauta pennsylvanica, De G. 


\section{INSECTS AND THEIR ALLIES}

\section{Rhipiphoridae.}

Myodites luteipennis, Lec.

" zeschii, Lec.

Rhinomaceridae.

Rhinomacer elongatus, Lec.

Rhynchitidae.

Eugnamptus angustatus, Hbst.

Rhynchites cyanellus, Lec.

\section{Attelabidae.}

Attelabus analis, Ill.

Otiorhynchidae (Scarred Snout-beetles).

Hormorus undulatus, Uhl.

Anametis grisea, Horn.

Panscopus erinaceus, Say.

Phyxelis rigidus, Say.

Otiorhynchus sulcatus, Fab.

$$
\text { “ ovatus, Linn. }
$$

Pandeletejus hilaris, Hbst.

Cyphomimus dorsalis, Horn.

Scythropus elegans, Coup.

Barypithes pellucidus, Boh.

Curculionidae (Curculios, Weevils),

Sitones flavescens, Marsh.

Ithycerus noveboracensis, Forst.

Podapion gallicola, Riley.

Phytonomus punctatus, Fab.

"6

$$
\text { nigrirostus, Fab. }
$$

Lepyrus geminatus, Say.

Listronotus sordidus, Gyll.

“ callosus, Lec. 


\section{NATURAL HISTORY, TORONTO REGION}

Curculionidae (Curculios, Weevils)-(Continued).

Listronotus appendiculatus, Boh.

" latiusculus, Boh.

Macrops delumbus, Gyll.

" sparsus, Say.

" porcellus, Say.

" solutus, Boh.

Pissodes strobi, Peck.

" affinis, Rand.

Hylobius pales, Hbst.

Lixus rubellus, Rand.

" concavus, Say.

Stephanocleonus plumbeus, Lec.

Dorytomus laticollis, Lec.

$\begin{array}{ll}\text { " } & \text { brevicollis, Lec. } \\ & \text { hirtus, Lec. }\end{array}$

Grypidius equiseti, Fab.

Erycus puncticollis, Lec.

Onychilis nigrirostris, Boh.

Endalus limatulus, Gyll.

" ovalis, Lec.

Anchodemus angustus, Lec.

Lissorhoptrus simplex, Say.

Otidocephalus scrobicollis, Boh.

Magdalis lecontei, Horn.

" pandura, Say.

" armicollis, Say.

“ pallida, Say.

Anthonomus quadrigibbus, Say.

"6

nebulosus, Lec. 


\section{INSECTS AND THEIR ALLIES}

Curculionidae (Curculios, Weevils)-(Continued).

Anthonomus profundus, Lec.

66

66

66

66

66

66 scutellatus, Gyll.

signatus, Say.

sycophanta, Walsh.

corvulus, Lec.

pusillus, Lec.

crataegi, Walsh.

Orchestes minutus, Horn.

66

niger, Horn.

" ephippiatus, Say.

Eleschus ephippiatus, Say.

Proctorus armatus, Say.

Thysanocnemis fraxini, Lec.

Gymnetron teter, Fab.

Conotrachelus juglandis, Lec.

"6

66

66

66 nenuphar, Hbst.

crataegi, Walsh.

posticatus, Boh.

anaglypticus, Say.

Rhyssematus lineaticollis, Say.

Acamptus rigidus, Lec.

Tyloderma aereum, Say.

Cryptorhynchus parochus, Hbst.

" bisignatus, Say.

Copturus operculatus, Say. Acoptus suturalis, Lec.

Cnemogonus epilobii, Payk.

Ceutorhynchus rapae, Gyll. 
Curculionidae (Curculios, Weevits)-(Continued).

Ceutorhynchus sulcipennis, Lec.

“ decipiens, Lec.
" cyanipennis.
septentrionis, Gyll.

Rhinoneus pericarpius, Linn.

“ pyrrhopus, Lec.

Baris transversa, Say.

Madarus undulatus, Say.

Stethobaris tubulatus, Say.

Balaninus nasicus, Say.

" rectus, Say.

\section{Brenthidae.}

Eupsalis minuta, Drury.

Calandridae (Bill-bugs).

Sphenophorus ochreus, Lec.

“ costipennis, Horn.

“ sculptilis, Ohl.

Calandra oryzae, Linn.

Dryophthorus corticalis, Say.

Cossonus platalea, Say.

" corticola, Say.

Rhyncholus brunneus, Mann.

Stenoscelis brevis, Boh.

Scolytidae (Engraver-beetles, etc.).

Gnathotrichus materiarius, Fitch.

Pityophthorus minutissimus, Zimm.

Pityogenes sparsus, Lec.

Xyloterus bivittatus, Kirby.

" politus, Say. 


\section{INSECTS AND THEIR ALLIES}

Scolytidae (Engraver-beetles, etc.)-(Continued).

Xyleborus celsus, Eich.

Tomicus caelatus, Eich.

" calligraphus, Germ.

" pini, Say.

Eccoptogaster rugulosus, Ratz.

Hylesinus aculeatus, Say.

Phloeosinus dentatus, Say.

Dendroctonus valens, Lec.

Hylurgops pinifex, Fitch.

\section{Anthribidae.}

Allandrus bifasciatus, Lec.

Cratoparis lunatus, Fab.

Brachytarsus variegatus, Say.

\section{Order LEPIDOPTERA.}

Superfamily Papilionomea (Butterflies).

Papilionidae (Swallow-tails).

Iphiclides ajax, Linn.

Papilio glaucus, Linn, var. turnus, Linn.

" troilus, Linn.

" thoas, Linn.

" polyxenes, Fab.

Laertias philenor, Linn.

Pieridae (Pierids).

Pontia protodice, Bd.-Lec.

" napi, Linn.

" rapae, Linn.

Zerene caesonia, Stoll. 


\section{NATURAL HISTORY, TORONTO REGION}

Pieridae (Pierids)-(Continued).

Eurymus eurytheme, Bdv.

" philodice, Godart.

Nymphalidae (Fritillaries, Angle-wings, etc.).

Euptoieta claudia, Cram.

Speyeria idalia, Drury.

Argynnis cybele, Fab.

" aphrodite, Fab.

“ atlantis, Edw.

Brenthis myrina, Cram.

" bellona, Fab.

Euphydryas phaeton, Drury.

Charidryas nycteis, D. \& H.

" ismeria, B. \& L.

Phyciodes tharos, Drury.

" batesii, Reak.

“ carlota, Reak.

Polygonia interrogationis, Fab.

" comma, Harris.

" progne, Cramer.

Eugonia j-album, B. \& L.

Euvanessa antiopa, Linn.

Aglais milberti, Godart.

$\nabla$ anessa atalanta, Linn.

" huntera, Fab.

" cardui, Linn.

" caryae, Hbn.

Junonia coenia, Hbn.

Basilarchia arthemis, Drury.

66

archippus, Cramer.

352 


\section{INSECTS AND THEIR ALLIES}

Agapetidae (Satyridae) (Meadow-browns).

Cercyonis alope, Fab. var. nephele, Kirby.

Satyrodes canthus, Linn.

Cissia eurytris, Fab.

Lymnadidae (Milkweed Butterflies, etc.).

Anosia plexippus, Linn.

Libytheidae (Long-beaks).

Hypatus bachmani, Kirkland.

Lycaenidae (Blues, Coppers, Hairstreaks).

Thecla acadica, Edw.

" edwardsii, Saund.

" calanus, $\mathrm{Hbn}$.

" ontario, Edw.

“ liparops, B. \& I.

Incisalia niphon, Hbn.

Erora laeta, Edw.

Strymon titus, Fab.

Feniseca tarquinius, Fab.

Chrysophanus thoe, Bdv.

Epidemia epixanthe, B. \& L.

Heodes hypophlaeas, Bdv.

Rusticus scudderi, Edw.

Cyaniris ladon, Cram., vars, lucia, Kirby, marginata, Edw., violacea, Edw., and neglecta, Edw.

Everes comyntas, Godt.

Hesperiidae (Skippers).

Ancyloxypha numitor, Fab.

Atrytone hobomok, Harr.

Anthomaster leonardus, Harr. 


\section{NATURAL HISTORY, TORONTO REGION}

Hesperiidae (Skippers)-(Continued).

Thymelicus brettus, B. \& L.

" otho, S. \& A., var. egeremet,

Scudd.

" mystic, Scudd.

" cernes, B. \& L.

Polites peckius, Kirby.

" baracoa, Lucas.

Euphyes vestris, Bdv., var. metacomet, Harr.

Phycanassa viator, Edw.

Epargyreus tityrus, Fab.

Thorybes pylades, Scudd.

Pholisora catullus, Fab.

Thanaos brizo, B. \& L.

“ icelus, Lint.

" persius, Scudd.

" martialis, Scudd.

“ juvenalis, Fab.

Superfamily Sphingoidea.

Sphingidae (Hawk-moths or Sphinxes).

Hemaris diffinis, Bdv.

" thysbe, Fab.

Amphion nessus, Cram.

Specodina abbotti, Swainson.

Deilephila galii, Rott.

" lineata, Fab.

Pholus pandorus, $\mathrm{Hbn}$.

“ achemon, Drury.

354 


\section{INSECTS AND THEIR ALLIES}

Sphingidae (Hawk-moths or Sphinxes)-(Continued).

Ampelophaga choerilus, Cram.

$$
\begin{array}{ll}
\text { “ myron, Cram. } \\
\text { “ersicolor, Harr. }
\end{array}
$$

Phlegethontius quinquemaculata, Haworth. Sphinx kalmiae, S. \& A.

$$
\begin{aligned}
& \text { “ } \quad \text { drupiferarum, S. \& A. } \\
& \text { “ } \quad \text { luscitiosa, Clemens. } \\
& \text { “ } \\
& \text { chersis, Hbn. } \\
& \text { "eremitus, Hbn. }
\end{aligned}
$$

Ceratomia amyntor, Geyer. 66

$$
\text { undulosa, Walk. }
$$

Lapara bombycoides, Walk. Marumba modesta, Harris. Smerinthus jamaicensis, Drury. "6

$$
\text { cerysii, Kirby. }
$$

Paonias excaecatus, S. \& A.

$$
\text { " myops, S. \& A. }
$$

Cressonia juglandis, S. \& A.

\section{Superfamily Saturnoidea.}

\section{Saturniidae (Saturnians).}

Samia cecropia, Linn.

Callosamia promethea, Dru.

Tropaea luna, Linn.

Telea polyphemus, Cram.

Automeris io, Fab. 


\section{NATURAL HISTORY, TORONTO REGION}

Ceratocampidae (Royal-moths).

Anisota virginiensis, Dru.

“ rubicunda, Fab.

Superfamily Bombxcordea.

Syntomidae (Syntomids).

Scepsis fulvicollis, Hbn.

Lycomorpha pholus, Dru.

Ctenucha virginica, Charp.

Lithosiidae (Footman-moths).

Crambidia casta, Sanborn.

Hypoprepia miniata, Kirby.

Arctiidae (Tiger-moths).

Eubaphe brevicornis, Walk.

" quinaria, Grt.

Haploa lecontei, Bdv.

“ confusa, Lyman.

Estigmene acraea, Dru.

Hyphantria textor, Harris.

Isia isabella, S. \& A.

Phragmatobia fuliginosa, Linn.

Diacrisia virginica, Fab.

" latipennis, Stretch.

Apantesis virgo, Linn.

" virguncula, Kirby.

" parthenice, Kirby.

“ persephone, Grt.

“ arge, Dru.

" phyllira, Dru.

“ vittata, Fab. 


\section{INSECTS AND THEIR ALLIES}

Arctiidae (Tiger-moths)-(Continued).

Arctia caia, Linn.

Ammalo tenera, Hbn.

Euchaetias egle, Dru.

Halisidota tessellaris, S. \& A.

"6

maculata, Harris.

“ caryae, Harris.

Agaristidae (Wood-nymph Moths).

Alypia octomaculata, Fab.

Noctuidae (Owlet-moths).

Panthea furcilla, Pack.

Demas flavicornis, Smith.

Charadra deridens, $\mathrm{Gn}$.

Raphia frater, Grt.

Apatela americana, Harris.

" hastulifera, S. \& A.

" dactylina, Grt.

“ innotata, Gn.

“ morula, Grt.

" interrupta, Gn.

" clarescens, Gn.

“ superans, Gn.

" funeralis, Grt.

" fragilis, Gn.

" brumosa, Gn.

" impressa, Walk.

" impleta, Walk.

" illita, Sm.

" oblinita, S. \& A.

Arsilonche henrici, Grt. 


\section{NATURAL HISTORY, TORONTO REGION}

Noctuidae (Owlet-moths)-(Continued).

Harrisimemna trisignata, Walk.

Microcoelia diphteroides, Gn.

Jaspidia lepidula, Grt.

Chytonia palliatricula, $\mathrm{Gn}$.

Baileya ophthalmica, Gn.

Catabena lineolata, Walk.

Crambodes talidiformis, Gn.

Balsa malana, Fitch.

Caradrina multifera, Walk.

Oligia festivoides, Gn.

Hadena modica, Gn.

" mactata, Gn.

“ fractilinea, Grt.

" passer, Gn.

" apamiformis, Gn.

" lateritia, Hbn.

“ dubitans, Walk.

" impulsa, Gn.

" devastatrix, Brace.

" aretica, Bdv.

" verbascoides, $\mathrm{Gn}$.

" lignicolor, Gn.

Dryobota illocata, Walk.

Hyppa xylinoides, Gn.

Feralia major, Sm.

Momophana comstocki, Grt.

Euplexia lucipera, Linn.

Dipterygia scabriuscula, Linn.

Actinotia ramosula, Gn. 


\section{INSECTS AND THEIR ALLIES}

Noctuidae (Owlet-moths) - (Continued).

Pyrophila pyramidoides, Gn. trogopoginis, Linn.

Heliotropha reniformis, Grt. Homohadena badistriga, Grt. Psaphidia grotei, Morr.

Rhynchagrotis gilvipennis, Grt.

" anchoselioides, Gn.

Adelphagrotis prasina, Fab.

Platagrotis pressa, Grt.

Eueretagrotis sigmoides, Gn.

“ perattenta, Grt.

Semiophora tenebrifera, Walk.

Agrotis ypsilon, Lott.

“ geniculata, G. \& $R$.

Peridroma occulta, Linn.

“ saucia, Hbn.

Noctua smithii, Snellen.

" normaniana, Grt.

" bicarnea, Gn.

" c-nigrum, Linn.

" phyllophora, Grt.

" fennica, Tausch.

“ plecta, Linn.

" collaris, G. \& R.

" haruspica, Grt.

" clandestina, Harr.

Feltia ducens, Walk.

" jaculifera, Gn. 


\section{NATURAL HISTORY, TORONTO REGION}

Noctuidae (Owlet-moths)-(Continued).

Feltia herilis, Grt.

" venerabilis, Walk.

" volubilis, Harr.

Porosagrotis vetusta, Walk.

Euxoa velleripennis, Grt.

" scandens, Riley.

“ detersa, Walk.

" messoria, Harris.

" mollis, Walk.

" insulsa, Walk.

" albipennis, Grt.

" tessellata, Harr.

" ochrogaster, Gn.

" redimacula, Morr.

Anytus privatus, Walk.

Ufeus satyricus, Grt.

Mamestra nimbosa, Gn.

66

imbrifera, Gn.

66

purpurissata, Grt.

" meditata, Grt.

“ distincta, Hbn.

“ atlantica, Grt.

“ radix, Walk.

" nevadae, Grt.

“ subjuncta, G. \& R.

" grandis, Bdv.

" trifolii, Lott.

" rosea, Harv.

“ picta, Harr.

360 


\section{INSECTS AND THEIR ALLIES}

Noctuidae (Owlet-moths)-(Continued).

Mamestra assimilis, Morr.

$\begin{array}{ll}\text { " } & \text { latex, Gn. } \\ \text { " } & \text { legitima, Grt. } \\ \text { " } & \text { lilacina, Harv. } \\ \text { " } & \text { renigera, Stephens. } \\ \text { " } & \text { olivacea, Morr. } \\ & \text { lorea, Gn. }\end{array}$

Morrisonia, confusa, $\mathrm{Hbn}$.

" sectilis, Gn. var. vomerina, Grt.

Nephelodes minians, Gn.

Heliophila unipuncta, Haw.

$\begin{array}{ll}\text { " } & \text { pseudargyria, Gn. } \\ \text { "luteopallens, Sm. } \\ \text { " } & \text { ilbilinea, Hibn. } \\ \text { " } & \text { commota, Gn. } \\ \text { " } & \text { phragmatidicola, Gn. }\end{array}$

Orthodes crenulata, Butler.

"6

cynica, Gn.

" vecors, Gn.

Himella contrahens, Walk.

Crocigrapha normani, Grt.

Graphiphora alia, Gn.

Tricholita signata, Walk.

Lithomoia germana, Morr.

Xylina disposita, Morr.

" laticinerea, Grt.

" grotei, Riley. 


\section{NATURAL HISTORY, TORONTO REGION}

Noctuidae (Owlet-moths)-(Continued).

Xylina ferrealis, Grt.

“ innominata, $\mathrm{Sm}$.

" bethunei, G. \& R.

" semiusta, Grt.

" fagina, Morr.

" unimoda, Lintner.

" pexata, Grt.

Litholomia napaea, Morr.

Calocampa nupera, Lint.

" curvimacula, Morr.

Cucullia convexipennis, G. \& R.

“ asteroides, Gn.

" intermedia, Speyer.

Sphida obliqua, Walk.

Achatodes zeae, Harris.

Gortyna velata, Walk.

" nictitans, Bork.

Papaipema cataphracta, Grt.

Pyrrhia umbra, Hufn.

" experimens, Walk.

Xanthia flavago, Fab.

Brotolomia iris, Gn.

Trigonophora periculosa, Gn.

Eucirroedia pampina, Gn.

Scoliopteryx libatrix, Linn.

Cosmia discolor, Walk.

Orthosia bicolorago, Gn.

" euroa, G. \& R.

Parastichtis discivaria, Walk. 


\section{INSECTS AND THEIR ALLIES}

Noctuidae (Owlet-moths)-(Continued).

Scopelosoma moffatiana, Grt.

$\begin{array}{ll}\text { " ceromatica, Grt. } \\ \text { " } & \text { walkerigmata, Grt. } \\ \text { " } & \text { morrisoni, Grt. }\end{array}$

Glaea inulta, Grt.

Homoglaea hircina, Morr.

Heliothis armiger, Hbn.

Rhodophora florida, Gn.

Schinia marginata, Haw.

Euthisanotia unio, Hbn.

66

grata, Fab.

Plusiodonta compressipalpis, Gn.

Calpe canadensis, Bethune.

Panchrysia purpurigera, Walk.

Plusia aerea, Hbn.

" aeroides, Grt.

" balluca, Geyer.

Euchalcia contexta, Grt.

" venusta, Walk.

Autographa bimaculata, Steph.

66

66

16

66

66

6

"6

66 biloba, Steph.

precationis, Gn. rogationis, Gn. brassicae, Riley. octoscripta, Grt. rectangula, Kirby. viridisignata, Grt. epigaea, Grt. 363 
Noctuidae (Owlet-moths)-(Continued).

Autographa ampla, Walk.

$$
\text { " } \quad \text { falcigera, Kirby. }
$$

Abrostola urentis, Gn.

Ogdoconta cinereola, Gn.

Marasmalus inficita, Walk.

Rivula propinqualis, $\mathrm{Gn}$.

Eustrotia albidula, Gn.

$$
\begin{array}{ll}
\text { " synochitis, G. \& R. } \\
\text { " moscoscula, Gn. } \\
\text { carneola, Gn. }
\end{array}
$$

Chamyris ceraintha, Treit.

Tarache erastriodes, Gn.

Metathorasa monitifera, Gn.

Euherrichia mollissima, Gn.

Hyamia sexpunctata, Grt.

Homopyralis discalis, Grt.

Drasteria erechtea, Cramer.

Euclidia cuspidea, Hbn.

Meliopotis limbolaris, Geyer.

Catocala viduata, $\mathrm{Gn}$.

$$
\begin{array}{ll}
\text { “ } & \text { retecta, Grt. } \\
\text { " obscura, Strecker. } \\
\text { " } & \text { insolabilis, Gn. } \\
\text { " } & \text { relicta, Walk. } \\
\text { “ } & \text { cara, Gn. } \\
\text { " amatrix, Hbn. } & \text { concumbens, Walk. } \\
\text { " } & \text { unijuga, Walk. } \\
& 364
\end{array}
$$




\section{INSECTS AND THEIR ALLIES}

Noctuidae (Owlet-moths)-(Continued).

Catocala briseis, Edw.

66

parta, Gn.

" ultronia, Hbn.

" ilia, Cram.

" neogama, S. \& A.

" cerogama, Gn.

" antinympha, Hbn.

" habilis, Grt.

" crataegi, Saund.

Euparthenos nubilis, Hbn.

Panapoda rufimargo, Hbn.

Parallelia bistriaris, Hbn.

Remigia repanda, Fab.

Zale horrida, Hbn.

Pheocyma lunata, Dru.

“ nigricans, Bethune.

" duplicata, Bethune.

Ypsia undularis, Dru.

Erebus odora, Linn.

Thysania zenobia, Cram.

Epizeuxis americalis, Gn.

“ aemula, Hbn.

" lubricalis, Geyer.

Zanclognatha laevigata, Grt. pedipilalis, Gn.

" marcidilinea, Grt.

Hormisa absorptalis, Walk.

Philometra eumelusalis, Walk.

Chytolita morbidalis, Gn. 


\section{NATURAL HISTORY, TORONTO REGION}

Noctuidae (Owlet-moths)-(Continued).

Renia flaripunctalis, Gejer.

Bleptina caradrinalis, Gn.

Palthis angulalis, Hbn.

Bomolocha baltimoralis, Gn.

" albilinealis, $\Pi$ alk.

Plathypena scabra, Fab.

Hrpena humuli, Harris.

\section{Notodontidae.}

Melalopha albosigma, Fitch.

Datana ministra, Dru.

" drexelii, Hy. Edw.

" integerrima, G. \& R.

Hiperaeschra stragula, Grt. "

georgica, H.-S.

Notodonta basitriens, Walk.

" simplaria, Graef.

Pheosia dimidiata, H.-S.

Lophodonta ferruginea, Pack. " angulosa, S. \& A.

Nadata gibbosa, S. \& A.

Nerice bidentata, Walk.

Srmmerista albifrons, S. \& A.

Dasylophia thyatiroides, Walk.

Heterocampa manteo, Dbd.

$$
\text { " umbrata, Walk. }
$$

Schizura ipomoeae, Dbd.

" concinna, S. \& A.

“ unicornis, S. \& A.

366 


\section{INSECTS AND THEIR ALLIES}

Notodontidae (Continued).

Schizura badia, Pack.

“ Ieptinoides, Grt.

Cerura occidentalis, Lint.

Harpyia cinerea, Walk.

" scolopendrina, Bdv.

Fentonia marthesia, Cramer.

Gluphisia septentriona'is, Walk.

Ellida caniplaga, Walk.

\section{Thyatiridae.}

Habrosyne scripta, Gosse.

Pseudothyatira cymatophoroides, Gn. " expultrix, Grt.

Liparidae (Tussock-moths).

Notolophus antiqua, Linn.

Hemerocampa leucostigma, S. \& A.

Olene plagiata, Walk.

Lasiocampidae (Tent-caterpillar Family).

Tolype velleda, Stoll.

Malacosoma americana, Fab.

“ disstria, Hbn.

Epicnaptera americana, Harr.

Platypterygidae (Hook-tip Moths).

Eudeilinea herminiata, Gn.

Drepana arcuata, Walk.

Falcaria bilineata, Pack.

Geometridae (Geometrids, Measuring-worms).

Dyspteris abortivaria, H.-S.

Nyctobia limitaria, Walk. 
Geometridae (Geometrids, Measuring-worms) -(Contin'd)

Cladora atroliturata, Walk.

Alsophila pometaria, Harr.

Eudule mendica, Walk.

Talledega tabulata, Hulst.

Nannia refusaria, Walk.

Heterophleps triguttaria, H.-S.

Eupithecia indistincta, Taylor.

Eucymatoge intestinata, Gn.

Venusia cambrica, Curtis.

Trichodezia albovittata, Gn.

Epirrita dilutata, D. \& S.

Hydria undulata, Linn.

Eustroma diversilineata, Hbn.

Rheumaptera hastata, Linn.

" sociata, Bork.

Percnoptilata fluviata, Hbn.

Mesoleuca ruficillata, Gn.

“ lacustrata, Gn.

“ vasiliata, $\mathrm{Gn}$.

Hydriomena autumnalis, Strom.

" multiferata, Walk.

" latirupta, Walk.

Triphosa indubitata, Grt.

Gypsochroa designata, Hufn.

Xanthorhoe ferrugata, Clerck.

Haematopsis grataria, Fabr.

Cosymbia lumenaria, Hbn.

Synelys ennucleata, Gn.

Chlorochlamys chloroleucaria, $\mathrm{Gn}$. 


\section{INSECTS AND THEIR ALLIES}

Geometridae (Geometrids, Measuring-worms) -(Contin'd)

Eucrostis incertata, Walk.

Aplodes miniosaria, Gn.

Eufidonia notataria, Walk.

Corycia vestaliata, $\mathrm{Gn}$.

Physostegania pustularia, Gn.

Gueneria basiata, Pack.

Deilinia variolaria, Gn.

" erythremaria, Gn.

Sciagraphia granitata, Gn.

" mellistrigata, Grt.

Philobia enotata, Gn.

Macaria bisignata, Walk.

Diastictis ribearia, Fitch.

Homochlodes fritillaria, Gn.

Apaecasia detersata, Gn.

" defluata, Walk.

Nepytia semiclusaria, Walk.

Paraphia subatomaria, Wood.

Selidosema humaria, Gn.

Melanolophia canadaria, Gn.

Ectropis crepuscularia, D. \& S.

Lycia ursaria, Walk.

" cognataria, $\mathrm{Gn}$.

Nacophora quernaria, S. \& A.

Paleacrita vernata, Peck.

Phigalia titea, Cramer.

Erannis tiliaria, Harr.

Cingilia catenaria, Dru.

Anagoga pulveraria, Linn. 
Geometridae (Geometrids, Measuring-worms) - (Contin'd)

Therina fiscellaria, Gn.

Metrocampa perlata, Gn.

Eugonobapta nivosaria, Gn.

Ennomos subsignarius, Hbn.

" magnarius, $\mathrm{Gn}$.

Xanthotype crocataria, Fab.

Plagodis phlogosaria, Gn.

$$
\text { " serinaria, H.-S. }
$$

Hyperetis amicaria, H.-S.

Ania limbata, Haw.

Gonodontis hypocharia, H.-S.

" duaria, Gn.

" obfirmaria, Hbn.

Euchlaena effectaria, Walk.

" marginata, Minot.

Eutrapela alciphearia, Walk.

Metanema inatomaria, Gn.

" determinata, Walk.

Pero honestarius, Walk.

Caberodes confusaria, Hbn.

Tetracis crocallata, Gn.

Sabulodes lorata, Grt.

" transversata, Drury.

Abbotana clemataria, S. \& A.

Brephos infans, Moeschl.

Limacodidae (Slug-caterpillar Moths).

Euclea delphinii, Bdv.

Natada nasoni, Grt.

Tortricidea testacea, Pack. 


\section{INSECTS AND THEIR ALLIES}

Thyridae (Window-winged Moths).

Thyris maculata, Harris.

Cossidae (Carpenter-moths).

Cossus centerensis, Lint.

Prionoxystus robiniae, Peck.

Sesiidae (Clear-wing Moths).

Bembecia marginata, Harris.

Sesia tipuliformis, Clerck.

" acerni, Clemens.

Pyralidae (Pyralids).

Desmia funeralis, Hbn.

Blepharomastix ranalis, $\mathrm{Hbn}$.

Pantographia limata, G. \& R.

Diaphania quadristigmalis, Gn.

Hellula undalis, Fab.

Evergestis straminalis, Hbn.

Crocidophora serratissimalis, Zeller.

Nomophila noctuella, D. \& S.

Loxostege chortalis, Grt.

" nasonialis, Zeller.

Phlyctaenia ferrugalis, Hbn.

"6 acutella, Walk.

Pyrausta fissalis, Grt.

" illibalis. Hbn.

" fodinalis, Led.

" signatalis, Walk.

" funebris, Strom.

Nymphula icciusalis, Walk. badiusalis, Walk.

Pyralis farinalis, Linn. 


\section{NATURAL HISTORY, TORONTO REGION}

Pyralidae (Pyralids) -(Continued).

Hypropygia costalis, Fab.

Schoenobius forficellus, Thunb.

Crambus girardellus, Clemens.

" laqueatellus, Clemens.

" albellus, Clemens.

“ hortuellus, Hbn.

“ perlellus, Scop.

“ elegans, Clemens.

" vulgivagellus, Clemens.

" trisectus, Walk.

" alboclavellus, Zeller.

Argyria nivalis, Drury.

" auratella, Clem.

Galleria mellonella, Linn.

Acrobasis betnlella, Hulst.

Mineola indiginella, Zeller.

Ephestia kuchniella, Zeller.

Plodia interpunctella, Hbn.

Pterophoridae (Plume-moths).

Oxyptilus periscelidactylus, Fitch.

" tenuidactylus, Fitch.

Platyptilia marginidactyla, Fitch.

Pterophorus monodactylus, Linn.

“ eupatorii, Fern.

Tortricidae (Tortricids).

Retinia austriana, Cosens.

Exartema exoletum, Zeller.

Olethreutes campestrana, Zeller.

Eucosma cataclystiana, Walk. 


\section{INSECTS AND THEIR ALLIES}

\section{Tortricidae (Tortricids)-(Continued).}

Eucosma abbreviatana, Walsm.

“ scudderiana, Clemens.

" pergandeana, Fern.

Thiodia striatana, Clem.

Proteopteryx costomaculana, Clem.

Imetocera ocellana, Schiff.

Ancylis discigerana, Walk.

“ semiovana, Zeller.

Enarmonia interstinctana, Clemens.

" saundersana, Kearf.

Carpocapsa pomonella, Linn.

Archips rosaceana, Harris.

66

purpurana, Clemens.

" cerasivorana, Fitch.

" fervidana, Clemens.

" melaleucana, Walk.

Tortrix albicomana, Clemens.

" fumiferana, Clemens.

“ semipurpurana, Kearf.

Eulia quadrifasciana, Fern.

" pinatubana, Kearf.

Phalonia vitellinana, Zeller.

\section{Yponomeutidae.}

Plutella maculipennis, Curtis.

\section{Gelechiidae.}

Gnorimoschema gallaesolidaginis, Riley. “ gallaeasteriella, Kell.

Metzneria lappella, Linn. 


\section{NATURAL HISTORY, TORONTO REGION}

Gelechiidae (Continued).

Anacampsis lupinella, Busck.

Ypsolophus ligulellus, Hbn.

\section{Ecophoridae.}

Machimia tentoriferella, Clemens.

Depressaria atrodorsella, Clemens.

" heracliara, DeGeer.

\section{Blastobasidae.}

Holocera purpurocomella, Clemens.

\section{Elachistidae.}

Stagmatophora ceanothiella, Cosens.

Coleophora fletcherella, Fern.

Lymnaecia phragmitiella, Stainton.

Mompha brevivittella, Clemens.

Tineidae.(Clothes-moths, etc.).

Nepticula pomivorella, Pack.

Bucculatrix canadensisella, Chamb.

Tineola bisselliella, Hummel.

Tinea pellionella, Linn.

Trichophaga tapetzella, Linn.

Hepialidae (Ghost-moths).

Sthenopis argenteomaculatus, Harris.

“ quadriguttatus, Grt.

\section{Order HYMENOPTERA.}

Species marked (B) were taken from Dr. Brodie's MS. notes and were determined chiefly by Ashmead; those marked (C) were contributed by Dr. Cosens; 


\section{INSECTS AND THEIR ALLIES}

the others are in the collection of the Provincial Museum, collected by Dr. Brodie.

Superfamily Tenturedinoidea.

Lydidae (Saw-flies).

Anoplolyda luteicornis, Nort.

Tenthredinidae (Saw-flies).

Allantus cinctus, Linn.

Strongylogaster annulosus, Harr.

Dolerus aprilis, Nort.

" similis, Nort.

Lagium atroviolaceum, Nort. Tenthredella albifrons, Prov.

66

66

66

"6

《

66

6

66 melanosoma, Harrington.

mellicoxae, Prov.

mellina, Nort.

rufopecta, Nort.

signata, Nort.

varipes, Nort.

varipicta, Nort.

verticalis, Say.

Macrophya epinota, Say.

" $\quad$ flavicoxae, Nort.

Tenthredo basilaris, Say.

"unicinctulus, D. T.

Trichiosoma triangulum, Kirby.

Cimbex americana, Leach.

Euura serissimae, Rohwer (C). 


\section{NATURAL HISTORY, TORONTO REGION}

2

Tenthredinidae (Saw-flies)-(Continued).

Euura s-gemina, Walsh (C).

$$
\text { " s-orum, Walsh (C). }
$$

Pontania crassicornis, Rohwer (C).

" desmodioides, Walsh (C).

" hyalina, Norton (C).

" lucidae, Rohwer (C).

" pisum, Walsh (C).

" pomum, Walsh (C).

Pteronidea ribesi, Scop.

Nematus erichsonii, Hartig (Walker). Arge scapularis, King.

\section{Siricidae (Horn-tails).}

Tremex columba, Linn. (Walker).

\section{Superfamily Crxipoidea.}

Cynipidae (Gall-flies, etc.).

Synergus quercus-lanae, Fitch (B).

" lignicola, O. S. (B).

" oneratus, Harr. (B).

Ceroptres ficus, Fitch (B).

" petiolicola, O. S. (B)

" tuber, Fitch (B).

" frondosae, Ashm. (B).

Philonyx erinacei, Beut. (C).

" hirta, Bass. (C).

" nigra, Gillette (C).

Biorhiza forticornis, Walsh (C) (B).

Neuroterus batatus, Fitch (C) (B).

376 


\section{INSECTS AND THEIR ALLIES}

Cynipidae (Gall-flies, etc.)-(Continued).

Neuroterus majalis, Bass. (C).

" minutus, Bass. (C).

Dryophanta lanata, Gill. (B).

$$
\text { " } \quad \text { palustris, O. S. (C). }
$$

Holeaspis bassetti, Gillette (C).

66

globulus, Fitch (C).

" mamma, Walsh (C).

Cynips (?) constricta, Stebbins (C). Amphibolips coccineae, Harr. (B).

" confluens, Harr. (C) (B).

" inanis, O. S. (C).

" nubilipennis, Harr. (B).

Andricus futilis, O. S. (B).

" impricariae, Ashm. (C).

" lana, Fitch (C).

" petiolicola, Bass. (C) (B).

" piger, Bass. (C).

" punctatus, Bass. (C).

" seminator, Harr. (C).

" singularis, Bass. (C).

" topiarus, Ashm. (C).

Solenozopheria vaccinii, Ashm. (C).

Diastrophus cuscutaeformis, Ashm.(C) (B)

" fusiformis, Ashm. (C).

" turgidus, Ashm. (C) (B).

Aylax glecomae, L. (C).

Aulacidea nabali, Brodie (C) (B).

" tumida, Bass. (C). 


\section{NATURAL HISTORY, TORONTO REGION}

Cynipidae (Gall-flies, etc.)-(Continued).

Rhodites dichlocerus, Harr. (C).

" globulus, Beut. (C).

" gracilis, Ash. (C) (B).

" ignotus, O. S. (C).

" multispinosus, Gill. (C).

" nebulosus, Bass. (C) (B).

“ radicum, O. S. (B).

" rosae, L. (C).

Superfamily Ichneumonoidea.

Braconidae (Braconids).

Macrocentrus uniformis, Cress. (B).

Meteorus vulgaris, Cress. (B).

Rogas intermedius, Cress (B).

Microbracon dorsator, Say (B).

Ichneumonidae (Ichneumon-flies).

Orthopelma diastrophi, Ashm.

Ceratogastra fasciata, Cress.

Exetastes suaveolens, Walsh.

Opheltes glaucopterus, Linn.

Sagaritis dubitata, Cress.

Campoplex valida, Cress.

Exochilum morio, Fab. (mundum, Say).

Enicospilus purgatns, Say.

Thyreodon morio, Fab.

Ophion bilineatus, Say.

Allocamptus macrurus, Linn.

Mesoleius submarginatus, Cress. 


\section{INSECTS AND THEIR ALLIES}

Ichneumonidae (Ichneumon-flies)-(Continued).

Tryphon communis, Cress.

Conoblasta erratica, Cress.

Itoplectis conquisitor, Say. " marginatus, Prov.

Epiurus pterelas, Say.

Eremochila indagatrix, Salsh.

Iseropus inquisitoriella, D. T.

Pimpla pedalis, Cress.

Ephialtes irritator, F.

“ tuberculatus, Fourc.

Megarhyssa atrata, F.

" lunator, $\mathrm{F}$.

Rhyssa persuasoria, Linn.

Lissonota americana, Cress.

“ varia, Cress.

“ exilis, Cress.

" rufipes, Cress.

" frigidus, Cress.

" humeralis, Prov.

Arotes vicinus, Cress.

Mesostenus thoracicus, Cress.

c6

arvalis, Cress.

Cryptus americanus, Cress.

" extrematis, Cress.

“ limatus, Cress.

" persimilis, Cress.

“ ruficornis, Prov.

" rufoannulatus, Prov.

Hemiteles humeralis, Prov. 


\section{NATLRAL HISTORY, TORONTO REGION}

Ichneumonidae (Ichneumon-flies)-(Continued).

Phygadeuon rotundiceps, Prov.

Ichneumon acerbas, Cress.

66

66

66

66

66

66

66

66

66

66

66

66

66

66

66

66

66

66

66

66

66

66

66

66

66

66 brevicinctor, Say.

bronteus, Cress.

caliginosus, Cress.

canadensis, Cress.

coeruleus, Cress.

comes, Cress.

creperus, Cress.

duplicatus, Cress.

flavicornis, Cress.

flavizonatus, Cress.

grandis, Brullé.

hebrus, Cress.

helvipes, Cress.

jucundus, Brullé.

laetus, Brullé.

milvus, Cress.

paratus, Say.

partus, Cress.

puerilis, Cress.

restrictus, Cress.

rufiventris, Brullé.

stygicus, Cress.

subcyaneus, Cress.

subdolus, Cress.

unifasciatorius, Say.

vescus, Prov.

Amblyteles montanus, Cress. 


\section{INSECTS AND THEIR ALLIES}

Ichneumonidae (Ichneumon-flies)-(Continued).

Amblyteles nubivagus, Cress.

“ $\quad$ subrufus, Cress.
" $\quad$ ulturalis, Say.
"ress.
obsidianator, Brullé.
vulpinus, Grav.

\section{Evaniidae.}

Gasteruption montanus, var. incertus, Cress. “ tarsatorius, Say.

\section{Superfamily Chalcidoidea.}

Callimomidae (Torymidae).

Callimome brevissimicauda, Ashm. (brevicauda, O. S.) (B). " bedeguaris, Linn. (magnifica, O. S.) (B).

“ splendidulus (Barnstorf) Walker (B).

Syntomaspis brodiei, Ashm. (B). " elegantissima, Ashm. (B).

Megastigmus canadensis, Ashm. (B). Ormyrus vaccinicola, Ashm. (B). " ventricosus, Ashm. (B).

Diomorus biorhizae, Ashm. (B).

\section{Eurytomidae.}

Eurytoma diastrophi, Walsh (B). " gigantea, Walsh (B). 
Eurytomidae (Continued).

Eurytoma prunicola, Walsh (B).

" solenozopheriae, Ashm. (B).

" studiosa, Say (B).

Decatoma varians, Walsh (B).

\section{Chalcididae.}

Leucospis affinis, Say.

Perilampidae.

Perilampus platygaster, Say (B).

Pteromalidae.

Catolaccus rosae, Say (B).

\section{Encyrtidae.}

Encyrtus bucculatricis, How. (B).

Copidosoma gelechiae, How. (B).

\section{Eulophidae.}

Tetrastichus racemariae, Ashm. (B).

Sympiesis dolichogaster, Ashm. (B).

Superfamily Proctotripoidea (Proctotrypids).

\section{Pelecinidae.}

Pelecinus polyturator, Drury.

Superfamily Formicoidea (Ants).

The ants have not been studied. The only species we have determined is Camponotus herculeanus pennsylvanicus, De G.

Superfamily Vespordea (Wasps).

Tiphiidae.

Tiphia inornata, Say. 


\section{INSECTS AND THEIR ALLIES}

Chrysididae (Cuckoo-flies).

Hedychrum violaceum, Brullé.

Eumenidae (Solitary Wasps).

Eumenes fraternus, Say.

Odynerus (Symmorphus) debilis, Sauss.

\begin{tabular}{ccc} 
" & \multicolumn{2}{c}{ (Ancistrocerus) capra, Sauss. } \\
" & (Odynerus) arvensis, Sauss. \\
" & " & catskilli, Sauss. \\
" & & foraminatus, Sauss.
\end{tabular}

" (Stenodynerus) pennsylvanicus, Sauss.

Vespidae (Social Wasps).

Polistes pallipes, Lep.

Vespula consobrina, Sauss.

" diabolica, Sauss.

" germanica, Fab.

" maculata, Linn.

" vulgaris, Linn.

\section{Psammocharidae.}

Pseudagenia mellipes, Say.

Psammochares aethiops, Cress.

" $\quad$ philadelphicus, Lep.

Pompiloides marginatus, Say.

Episyron biguttatus, Fab.

Ceropales bipunctata, Say.

" fraterna, Smith.

" robinsonii, Cress. 
Pemphredonidae (Pemphredonids).

Psen niger, Pack.

Passalaecus mandibularis, Cress.

Sphecidae (Thread-waisted Wasps, Mud-daubers, etc.).

Sceliphron cementarium, Dru.

Chalybion coeruleum, Linn.

Sphex communis, Cress.

" conditor, Smith.

" luetuosa, Smith.

" procera, Dahlb.

Ammobia ichneumonea, $\mathrm{L}$.

Isodontia philadelphica, Lep.

Philanthidae (Philanthids).

Cerceris clypeata, Dahlb.

" nigrescens, Smith.

Eucerceris zonatus, Say.

Philanthus bilunatus, Cress.

" solivagus, Say.

Bembecidae (Bembecids).

Stictica ventralis, Fab.

Bembex fasciata, Fab.

Microbembex monodonta, Say.

Gorytidae (Gorytids).

Gorytes epphippiatus, Pack.

Crabronidae (Crabronids).

Crabro pegasus, Pack.

" aciculatus, Prov.

Solenius singularis, Smith.

“ interruptus, St. Farg.

384 


\section{INSECTS AND THEIR ALLIES}

\section{Oxybelidae.}

Oxybelus brodiei, Prov.

\section{Larridae.}

Astata unicolor, Say.

Trypoxylidae.

Trypoxylon clavatum, Say.

Superfamily Apotdea (Bees).

Halictidae (Sharp-tongued Burrowing Bees).

Halictus confusus, Smith.

" discus, Smith.

" distinguendus, D. T.

" imitatus, Smith.

" laevissimus, Smith.

" ligatus, Say.

" pilosus, Smith.

Augochlora pura, Say.

Agapostemon radiatus, Say.

“ $\quad$ virescens, Fab.

Sphecodes scabrosus, Prov.

Andrenidae (Sharp-tongued Burrowing Bees).

Andrena erythrogastra, Ashm.

Panurgidae.

Perdita octomaculata, Say.

Calliopsis 4-lineata, Prov.

Nomadidae (Cuckoo Bees).

Nomada bisignata, Say.

\section{Euceridae.}

Melissodes aurigenia, Cress. 


\section{NATURAL HISTORY, TORONTO REGION}

\section{Anthophoridae (Solitary Bees).}

Anthophora bomboides, Kirby.

\section{Prosopidae.}

Prosopis affinis, Smith.

Megachilidae (Mason Bees, Leaf-cutting Bees).

Megachile brevis, Say.

$$
\text { " vidua, Smith. }
$$

Osmia distincta, Cress.

Ceratinidae (Small Carpenter Bees).

Ceratina dupla, Say.

Xylocopidae (Large Carpenter Bees).

Xylocopa virginica, Dru.

Apidae (Honey-bees, Humble Bees)

$$
\begin{gathered}
\text { Psithyrus ashtoni, Cress. } \\
\text { " laboriosus, } \mathrm{F} \text {. }
\end{gathered}
$$

Bombus consimilis, Cress.

" fervidus, F.

" ternarius, Say.

" terricola, Kby.

" vagans, Smith.

Apis mellifera, I.

\section{Order DIPTERA.}

Species marked $(V)$ were taken by Mr. M. C. Van Duzee; those marked (B) are in the Provincial Museum, Toronto, collected by Dr. Brodie; those marked (C) were contributed by Dr. A. Cosens; those marked (W) by the writer. 


\section{INSECTS AND THEIR ALLIES}

Tipulidae (Crane-flies).

Discobola argus, Say (V).

Dicranomyia longipennis, Schu. ( $\nabla)$

$$
\text { " immodesta, O. S. (V). }
$$

Limnobia immatura, O. S. (V).

Rhamphidia flavipes, Macq. (V).

Rhypholopus meigenii, O. S. (V).

Erioptera straminea, O. S. $(V)$.

$\begin{array}{ll}\text { " } & \text { chlorophylla, O. S. }(\mathrm{V}) \text {. } \\ \text { " } & \text { armata, O. S. }(\mathrm{V}) \text {. } \\ \text { " } & \text { armillaris, O. S. }(\nabla) . \\ & \text { caloptera, Say }(\mathrm{V}) .\end{array}$

Epiphragma fascipennis, Say ( $\nabla)$.

Limnophila quadrata, O. S. (V).

Rhaphidolabis flaveola, O. S. (V).

Bittacomorpha clavipes, F. (IV).

Amalopis inconstans, O. S. (V).

Stygeropis fuscipennis, Loew (V).

Tipula grata, Loew (V).

$$
\text { " speciosa, Loew (V). }
$$

Dixidae (Dixa-midges).

$$
\text { Dixa clavata, Loew ( } V) \text {. }
$$

Psychodidae (Moth-like Flies).

Psychoda minuta, Banks (V).

$$
\text { " marginalis, Banks (V). }
$$

Psychoda alternata, Say (V).

\section{Chironomidae (Midges).}

Tanypus monilis, Linn. (V).

Chironomus flavisingula, Walk. ( $\nabla)$. 


\section{NATURAL HISTORY, TORONTO REGION}

Chironomidae (Midges)-(Continued).

Chironomus dux, Johans. ( $V)$.

6

albipennis, Meig. $(\nabla)$.

66 modestus, Say ( $\nabla)$.

66 aberrans, Johans. $(\nabla)$.

66 nigricans, Johans. ( $\nabla)$.

Culicidae"(Mosquitoes).

Anopheles punctipennis, Say (W).

Culex cantans, Meig. (Theobald).

" restuans, Theob. (Theobald).

" nemorosus, Theob. (Theobald).

Aedes fuscus, O. S. (Theobald).

Sayomyia punctipennis, Say $(\nabla)$.

" trivittata, Loew $(\nabla)$.

Mycetophilidae (Fungus-gnats).

Leia opima, Loew $(\nabla)$.

Sciara nigricans, Johans. ( $\nabla)$.

Cecidomyidae (Gall-gnats).

Lasioptera asterifoliae, Beut. (C). corni, Felt. (C).

" farinosa, O. S. (C).

" impatientifolia, Felt. (C).

" muhlenbergiae, Martin (C).

Neolasioptera perfoliata, Felt. (C).

Rhabdophaga batatas, Walsh (C, W).

$\begin{array}{ll}\text { " } & \text { brassicoides, Walsh (C, W). } \\ \text { " cornu, Walsh (C). } \\ \text { gnaphaloides, Walsh (C). } \\ \text { siliqua, Walsh (C). } \\ \quad 388\end{array}$




\section{INSECTS AND THEIR ALLIES}

Cecidomyidae (Gall-gnats)-(Continued).

Dasyneura solidaginis, Loew (C).

“ serrulatae, O. S. (C, W).

Rhopalomyia anthrophila, O. S. (C).

" alticola (C).

Mayetiola destructor, Say (W).

Cecidomyia albovittata, Walsh (IV).

" balsamicola, Walsh (C) (Bolton, Ont.)

" bedeguar, Walsh (C).

" bulla, Walsh (C).

" erigerontis, Brodie (Brodie).

" helianthi, Brodie (C).

" impatientis, O. S. (C).

" majalis, O. S. (C).

" ocellaris, O. S. (C).

" pellex, O. S. (C).

" pilulae, Walsh (C).

" poculum, O. S. (C).

" triticoides, Walsh $(\mathrm{C}, \mathrm{W})$.

" verrucicola, O. S. (C).

Bibionidae (March-flies).

Bibio albipennis, Say (V).

" xanthopus, Wied. (V).

Rhyphidae (False Crane-flies).

Rhyphus punctatus, Fab. (V).

Stratiomyidae (Soldier-flies).

Geosargus viridis, Say (V).

" decorus, Say (V).

389 


\section{NATURAL HISTORY, TORONTO REGION}

Stratiomyidae (Soldier-flies)-(Continued).

Microchrysa polita, Linn. (V).

Euparyphus tetraspilus, Loew (V).

Stratiomyia apicula, Loew (B).

$$
\begin{array}{ll}
\text { “ } & \text { badia, Walk. (B). } \\
\text { “ } & \text { discalis, Loew (B). } \\
\text { norma, Wied. (B). }
\end{array}
$$

Odontomyia cincta, Oliv. (B).

$$
\text { “ } \quad \text { interrupta, Oliv. (B). }
$$

Tabanidae (Horse-flies)

$$
\begin{array}{cl}
\text { Chrysops fallax, O. S. (V). } \\
\text { “ } & \text { fugax, O. S. (B). } \\
\text { “ } & \text { niger, Macq. (B). } \\
\text { " } & \text { striatus, O. S. (V). } \\
\text { " } \quad \text { univittatus, Macq. (B). } \\
\text { " } \quad \text { vittatus, Wied. (V). } \\
\text { Tabanus atratus, Fab. (B). } \\
\text { " lasiophthalmus, Macq. (B). } \\
\text { " lineola, Fab. (B). }
\end{array}
$$

Leptidae (Snipe-flies).

Xylophagus rufipes, Loew (V).

Xylomyia pallipes, Loew (V).

Leptis plumbea, Say $(V)$.

$$
\text { " scapularis, Loew }(\nabla) \text {. }
$$

Chrysopila ornata, Say (V).

$$
\text { “ quadrata, Say }(\nabla) \text {. }
$$

Bombyliidae (Bee-flies).

Anthrax alternata, Say (V). 


\section{INSECTS AND THEIR ALLIES}

Therevidae (Stiletto-flies).

Psilocephala pictipennis, Wied. $(\nabla)$. " haemorrhoidalis, Macq. $(\nabla)$.

Asilidae (Robber-flies).

Leptogaster flavipes, Loew (V).

Dasyllis grossa, Fab. (B).

$$
\text { posticata, Say (B). }
$$

Laphria sericea, Say (B).

Promachus bastardi, Macq. (V).

" quadratus, Wied. (B).

Proctacanthus philadelphicus, Macq. (B).

Asilus notatus, Wied. (V, B).

" novaescotiae, Macq. (B).

Dolichopodidae (Long-legged Flies).

Psilopodinus scobinator, Loew (W).

" sipho, Say (IV).

Campsicnemis hirtipes, Loew (W).

Porphyrops melampus, Loew $(\mathrm{V}, \mathrm{W})$.

“ rotundiceps, Loew $(\nabla)$.

Neurigona lateralis, Say (V).

“ maculata, M. VanDuzee $(\nabla)$.

Medeterus veles, Loew (V).

Dolichopus albiciliatus, Loew (W).

66

66

66

66

66

66

66 bifractus, Loew $(\nabla, W)$.

comatus, Loew ( $\mathrm{V}, \mathrm{W})$.

cuprinus, Wied. (V, W).

brevimanus, Loew (V).

detersus, Loew (V).

gratus, Loew (W).

lobatus, Loew (W). 


\section{NATURAL HISTORY, TORONTO REGION}

Dolichopodidae (Long-legged Flies)-(Continued).

Dolichopus remifer, Loew (V).

66

66

66

66

66 scoparius, Loew (W). setifer, Loew $(V)$. splendidus, Loew (W). tonsus, Loew (W). xanthocnemus, Loew (W).

Gymnopternus barbatulus, Loew $(\nabla, W)$. politus, Loew (W).

Tachytrechus vorax, Loew (W).

Pelastoneurus vagans, Loew $(\nabla, W)$.

Empididae (Dance-flies).

Platypalpus discifer (V).

Lonchopteridae (Spear-winged Flies).

Lonchoptera riparia, Meig. (V).

$$
\text { " lutea, Panz. (V). }
$$

Pipunculidae (Big-eyed Flies).

Pipunculus nitidiventris, Loew (V).

Syrphidae (Syrphus-flies).

Chrysotoxum ventricosum, Loew (B).

Chrysogaster pictipennis, Loew $(\nabla, W)$.

Pipiza pisticoides, Will. ? ( $V)$.

Paragus tibialis, Loew (W).

Chilosia sp. (W).

Baccha fascipennis, Wied. (B).

Ocyptamus fuscipennis, Say $(\nabla)$.

Platychirus quadratus, Say $(V, B, W)$.

Melanostoma mellinum, Linn. ( $V, B, W)$.

" obscurum, $\operatorname{Say}(B, W)$.

Didea fasciata, Macq. (W). 


\section{INSECTS AND THEIR ALLIES}

Syrphidae (Syrphus-flies)-(Continued).

Didea laxa, O. S. (B).

Syrphus abbreviatus, Zett. (B).

" americanus, Wied. ( $\mathrm{V}, \mathrm{B}, \mathrm{W})$.

" arcuatus, Fall. (B, W).

" lesueurii, Macq. ( $V, B, W)$.

" ribesii, Linn. (B, W).

" torrus, O. S. (B, W).

Allograpta obliqua, Say (B, W).

Mesogramma geminata, Say (B, W).

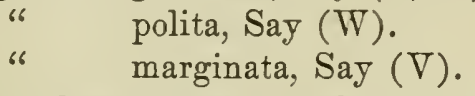

Sphaerophoria cylindrica, Say $(V, B, W)$.

Sphegina lobata, Loew (B, W).

Neoascia globosa, Walk. (V).

Rhingia nasica, Say (B, W).

Volucella evecta, Walk. (B, W).

Sericomyia chrysotoxoides, Macq. (B, W).

" militaris, Walk. ( $\mathrm{B}, \mathrm{W})$.

Eristalis bastardi, Macq. ( $\nabla, B, W)$.

" dimidiatus, Wied. (B, W).

" flavipes, Walk. $(B, W)$.

" meigenii, Wied. $(\mathrm{B}, \mathrm{W})$.

" tenax, Linn. (B, W).

“ transversus, Wied. (B, W).

Tropidia quadrata, Say (B, W).

Helophilus conostomus, Will. $(\nabla, \mathrm{B}, \mathrm{W})$.

" laetus, Loew (B, W).

" latifrons, Loew (B).

“ similis, Macq. (B, W). 


\section{NATURAL HISTORY, TORONTO REGION}

Syrphidae (Syrphus-flies)-(Continued).

Mallota posticata, Fab. (B, W).

" cimbiciformis, Fall (B).

Syritta pipiens, Linn. (B, W).

Xylota chalybea, Wied. (V).

$$
\begin{array}{ll}
\text { “ } & \text { curvipes, Loew (IV). } \\
\text { " juncida, Say (W). } \\
\text { " elongata, Will. (V). } \\
\text { " } \\
\text { fraudulosa, Loew (W). } \\
\text { pigra, Fab. (V, B). } \\
\text { vecors, O. S. (W). }
\end{array}
$$

Criorhina analis, Macq. (W).

" intersistens, Walk. (W).

Spilomyia fusca, Serv. (B).

$$
\text { “ quadrifasciata, Say (B). }
$$

Temnostoma alternans, Loew (B, W).

"

$$
\text { bombylans, F. (B, W). }
$$

Conopidae (Thick-head Flies).

Oncomyia abbreviata, Loew ( $\nabla$ ).

Oestridae (Bot-flies).

Gastrophilus equi, Clark (B, W).

Tachinidae (Tachina-flies).

Metachaeta helymus, Walk. (V).

Peleteria tessellata, Fab. (B).

Archytas analis, Fab. (B).

Echinomyia algens, Wied. (B).

Bombyliomyia abrupta, Wied. (B).

Sarcophagidae (Flesh-flies).

Sarcophaga sarraceniae, Riley (W). 


\section{INSECTS AND THEIR ALLIES}

Muscidae (House-fly Family).

Pollenia rudis, Fab. (V, W).

Calliphora vomitoria, Linn. (W).

Lucilia caesar, Linn. (W).

Musca domestica, Linn. (W).

Stomoxys calcitrans, Linn. (W).

Haematobia serrata, Desv. (W).

Anthomyidae (Anthomyia Flies).

Coenosia nudiseta, Stein (V).

Lispa albitarsis, Stein. (V).

Scatophagidae (Dung-flies).

Cordylura confusa, Loew ( $\nabla)$.

Parallelomma varipes, Walk. (V).

Scatophaga furcata, Say (V).

\section{Helomyzidae.}

Helomyza nemorum, Meig. (V).

Borboridae.

Limosina limosa, Meig. (V).

Borborus equinus, Fall. (V).

Sciomyzidae.

Neuroctena anilis, Fall. (V).

Tetanocera rotundicornis, Loew $(V)$.

“ velida, Loew (V).

" lineata, Day (V).

Sepedon fuscipennis, Loew (V).

Sapromyzidae.

Sapromyza decora, Loew (V).

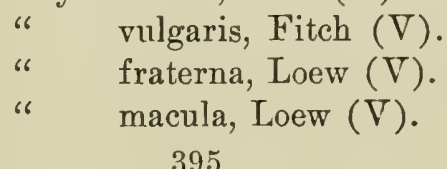

395 


\section{NATURAL HISTORY, TORONTO REGION}

\section{Ortalidae.}

Rivellia viridulans, Desv. (V).

" boscii, Desv. (W. H. Piersol).

" pallida, Loew $(\nabla)$.

Melieria similis, Loew $(V)$.

Pseudotephritis vau, Say (V).

Chaetopsis aenea, Wied. (V).

Seoptera vibrans, Linn. (V).

Trypetidae (Fruit-flies, etc.).

Straussia longipennis, Wied. (V).

Trypeta ruficoda, Fab. (V).

Euaresta bella, Loew $(\nabla)$.

Eurosta solidaginis, Fitch (Cosens).

Sepsidae.

Sepsis violacea, Meig. ( $\mathrm{V})$.

Nemopoda cylindrica, Fab. (V).

Ephydridae (Salt-water Flies).

Dichaeta caudata, Fall. $(\nabla)$.

Ochthera mantis, De G. (V).

Scatella stagnalis, Fall. (V).

Oscinidae (Grass-stem Flies).

Chlorops versicolor, Loew (V).

Eurina exilis, Coqu. (V).

Drosophilidae (Little Fruit Flies).

Drosophila amoena, Loew (V).

Geomyzidae.

Scyphella flava, Linn. ( $\nabla)$.

Agromyzidae.

Traginops irrorata, Coqu. (V). 


\section{INSECTS AND THEIR ALLIES}

\section{LITERATURE USEFUL IN IDENTIFICA- TION.}

(Only the more general descriptive works are cited here.)

Arachnida.

Banks, N. The Phalanginas of the United States (Can. Ent. XXV, pp. 205-211. 1893).

Banks, N. Synopses of North American Invertebrates, IX. The Scorpions, Solipugids and Pedipalpi (American Naturalist, XXXIV, pp. 421-427. 1900).

Banks, N. Synopses of North American Invertebrates, XVI. The Phalangida (Amer. Nat. XXXV, pp. 669-679. 1901).

Banks, N. A Treatise on the Acarina or Mites (Pr. U.S.N.M. XXVIII, pp. 1-114. 1904).

Banks, N. Synopses of North American Invertebrates, $\mathrm{XX}$, Families and Genera of Araneida (Amer. Nat. XXXIX, pp. 293-323. 1905). Banks, N. A Catalogue of the Acarina or Mites of the United States (Pr. U.S.N.M., XXXII, pp 595-625. 1907).

Comstock, J. H. The Spider Book; Doubleday, Page \& Co., New York, 1912.

Also many synopses of families, genera, etc., by. N. Banks, R. V. Chamberlin, J. H. Emerton, C. M. Weed, R. H. Wolcott, and others, in Trans. Amer. Ent. Soc.; Can. Entom.; Psyche; Journal N.Y. 397 


\section{NATURAL HISTORY, TORONTO REGION}

Ent. Soc.; Trans. Conn. Ac. Arts and Sc.; Pr. U.S.N.M.

Orthoptera and Dermatoptera.

Blatchley, W. S. The Orthoptera of Indiana (27th Ann. Rep. Dept. Geol. and Nat. Res. Ind., pp. 125-471, 1902).

Lugger, Otto. Orthoptera of Minnesota (Bull. 55, Minnesota Agric. Exper. Station, pp. 91-384, 1897).

Scudder, S. H. Guide to the Genera and Classification of the North American Orthoptera. Cambridge, Mass., 1897. (Contains a bibliography).

Walden, B. H. Guide to the Insects of Connecticut (W. H. Britton). Part II (Bull. Conn. Geol. and Nat. Hist. Survey, pp. 41-169. 1911).

Also many monographs and synopses of families and genera by S. H. Scudder, C. Brunner von Wattenwyl, H. de Sanssure, A. P. Morse, J. L. Hancock, J. McNeill, A. N. Caudell and others in Proc. Amer. Acad. Arts and Sc., Proc. U.S.N.M., Psyche, Can. Ent., etc.

\section{Plecoptera.}

Various papers by N. Banks and J. G. Needham and others in Trans. Am. Ent. Soc., Can. Ent., Psyche, Proc. Biol. Soc. Wash, etc. 


\section{INSECTS AND THEIR ALLIES}

Ephemerida.

Eaton, A. E. A Revisional Monograph of Recent Ephemeridae, or Mayflies (Trans. Linn. Soc. London, 1883-86, 6 parts).

Needham, J. G. Aquatic Insects in the Adirouldacks (Bull. 47, N.Y. State Mus. 1901).

Needham, J. G. May-flies and Midges of New York (Bull. 86, N.Y. State Mus., Ent. 23. 1905).

\section{Odonata.}

Calvert, P. P. Catalogue of the Odonata of the vicinity of Philadelphia (Trans. Amer. Ent. Soc., pp. 152-272. 1893).

Kellicott, D. S. The Odonata of Ohio (Ohio Acad. Sc., Special Paper No. 2, 114 pp. 1899). Muttkowski, R. A. Review of the Dragonflies of Wisconsin (Bull. Wis. Nat. Hist. Soc., VI, pp. 57-127. 1908).

Needham, J. G. Aquatic Insects in the Adirondacks (Bull. 47, N.Y. State Mus., pp. 383612. 1901).

Needham, J. G. Aquatic Insects in New York State (Bull. 68, N.Y. State Mus., Ent. 18, pp. 218-279. 1903).

Williamson, E. B. The Dragonflies of Indiana (24th Ann. Rep. Dep. Geol. and Nat. Res. Ind., pp. 229-333. 1900). 


\section{HEMtPTERA.}

Uhler, P. R. Report upon the insects collected by P. R. Uhler during the exploration of 1875 , including monographs of the families Cydnidae and Saldidae, and the Hemiptera collected by A. S. Packard, M.D. (U.S. Geol. and Geog. Surv., Bull., Vol. III, No. 2, pp. $355-475$. 1877).

Osborn, H. Classification of Hemiptera (Ent. Amer., Vol. 1, pp. 21-27. 1885).

Summers, H. E. The True Bugs, or Heteroptera, of Tennessee (Bull. Tenn. Agr. Expt. Sta., IV, No. 3, pp. 75-196. 1891.

Also many monographs and synopses of separate families, genera, etc., by P. R. Uhler, C. Stal, E. P. Van Duzee, H. Osborn, E. D. Ball, T. D. A. Cockerell, W. H. Ashmead, C. W. Woodworth and others, in Trans. Maryland Ac. Science, Trans. Amer. Ent. Soc. Bull. Ill. State Lab. Nat. Hist., Psyche, Can. Ent., Proc. Davenport Acad. Science, Bulls. U. S. Geol. Survey, etc.

\section{NeUroptera and Trichoptera.}

Van der Weele, H. W., Megaloptères. Coll. Zool. Selys Longchamps, Fasc. V, Pt. I.

Ulmer, G. Trichoptères, Coll. Zool. Selys Longchamps, Fasc.VI. 


\section{INSECTS AND THEIR ALLIES}

Ulmer, G. Trichoptera, Genera Insectorum, Fasc. $60 a$.

Also papers by N. Banks, R. P. Currie, C. Betten and others in Trans. Am. Ent. Soc., Can. Ent., Ent. News, Proc. Ent. Soc. Wash., etc.

\section{Coleoptira.}

Blatchley, W. S. An illustrated descriptive catalogue of the Coleoptera or Beetles (exclusive of the Rhynchophora) known to occur in Indiana (Bull. 1, Ind. Dep. Geol. and Nat. Res., 1,386 pp. 1910.

Also numerous monographs and synopses of separate families and genera by J. L. Leconte, G. H. Horn, T. L. Casey, H. F. Wickham, A. D. Hopkins and others, in Trans. Am. Ent. Soc., Proc. Phil. Ac. Sc., Journ. N.Y. Ent. Soc., Proc. Am. Phil. Soc., Can. Ent., etc.

\section{LEPIDOPTERA.}

Comstock, J. H. A Manual for the Study of Insects. Ithaca, 1895.

Edwards, W. H. The Butterflies of North America. 1868-1897.

Hampson, G. F. Catalogue of the Lepidoptera Pha-

laenae in the British Museum, Vols. I-XI. Holland, J. G. The Butterfly Book. New York, 1898. 


\section{NATURAL HISTORY, TORONTO REGION}

Holland, J. G. The Moth Book. New York, 1908. Scudder, S. H. The Butterflies of New England. Strecker, H. Lepidoptera, Rhopaloceres and Heteroceres, Indigenous and Exotic, etc. Reading, Pa., 1872-1877. Supplements 18981900.

Also numerous monographs and synopses of separate families, genera, etc., by A. S. Packard, A. R. Grote, J. B. Smith, B. Neumoegen, H. G. Dyar, G. F. Hampson and many others, in Journ. N.Y. Ent. Soc., Trans. Am. Ent. Soc., Bull. U.S.N.M., Proc. U.S.N.M., Bull. Buffalo Soc. Nat. Hist., Ent. News, Can. Ent. etc. (See "The Moth Book").

\section{Hymenoptera.}

Cresson, E. T. Synopsis of the families and genera of the Hymenoptera, north of Mexico, together with a Catalogne of the described species and bibliography (Trans. Am. Ent. Soc., supplementary volume, Part I. 1887).

Ashmead, W. H. Numerous papers on the classification of the various superfamilies; in Can. Ent., Trans. Am. Ent. Soc., and Journ. N.Y. Ent. Soc.

Also numerous monographs and synopses of separate families, genera, etc., by E. T. Cresson, W. H. Ashmead, W. J. Fox, Edward Norton, L. O. Howard and others, in Trans. Am. Ent. Soc., Can. Ent., Proc. 


\section{INSECTS AND THEIR ALLIES}

Ent. Soc. Phil., Proc. Ac. Nat. Sc. Phil., Bull. U.S.N.M., Bull. Div. Ent., U.S. Dep. Agric., etc.

\section{Diptera.}

Loew, H., and Osten Sacken, C.R. Monographs of the Diptera of North Africa, 4 parts (Smith. Miss. Coll., 1862-72 (Tipulidae, Cecidomyidae, Dolichopodidae, Ortalidae, Trypetidae, Ephydrinidae).

Townsend, C. H. T. The North American Genera of Nemocerous Diptera. (Trans. Am. Ent. Soc., pp. 144-160. 1892).

Williston, S. W. Manual of the Families and Genera of North American Diptera. Newhaven, Conn., 1896.

Also monographs and synopses of families, genera, etc., by D. W. Coquillett, S. W. Williston, C. H. T. Townsend and others, in Trans. Am. Ent. Soc., Journ. N.Y. Ent. Soc., Can. Ent., Ent. Amer., Bull. U.S.N.M. ; Tech. Series, Div. Ent., U.S. Dep. Agric.; Trans. Conn. Acad., etc. 


\section{CHAPTER XXIII.}

\section{EX C U R S I O N S.}

Bear Swamp occupies three or four hundred acres in Scarborough I'ownship. It is on Highland Creek about three or four miles from Lake Ontario. Take radial line at Woodbine to West Hill, walk down hill and turn north.

Bond Lake.-Take Metropolitan line to Bond Lake. There is a good supply of boats for hire here.

Brampton.-Reached by G.T.R. or C.P.R. Brampton is the home of the Dale nurseries, the rose houses of which corer a space of more than twenty acres under glass.

Burketon.-Take the C.P.R. to Burketon; go north along the Scugog road until Blackstock is reached; turn east to the swamp.

Burlington.-Take the G.T.R. for Hamilton; leave the railway at Burlington and walk southward to the lake.

Churchville.-On the C.P.R. just beyond Meadowvale. Eldorado, near by, is one of the few stations for the White Dog's-tooth Violet. 


\section{EXCURSIONS}

Credit Forks.-Take C.P.R. to Credit Forks. Here the Niagara escarpment reaches its maximum height. A section nearly 350 feet high has been exposed by the cutting action of a branch of the Credit river. "From the bed of the creek a slope of red clay extends upwards for approximately half the height of the escarpment. Overlying this is an exposure of Medina sandstone, while the top of the cliff furnishes an outcrop of 150 feet of nearly vertical limestone of the Niagara formation." Cosens. This is a naturalist's paradise.

Devil's Den.-Reached from Whitby by walking north $11 / 4$ miles, west $1 / 2$ mile, north $11 / 4$ miles, west 1 mile, north 11/4 miles; or by C.X.R.

“Dutch Church."-See at end of chapter on Geology.

Etobicoke.-Take the King Street West cars to their terminus; then the Port Credit car to Brown's stop; go down to the river and walk north.

Eversley Lake District.-The Eversley Lake district contains a number of small lakes belonging to the same group as Lakes Bond and Wilcox. The region possesses great variety of scenery, and the soil, although for the most part excellent for farming, is invaded in many places not only by lakes and small ponds, but often by a considerable extent of swampy ground surrounding these Much of this low-Iying land consists of 
peat-bogs, with the characteristic flora of pitcherplants, orchids, heaths, etc. Such is the general character of the country extending from Aurora to Richmond Hill and as far west as Schomberg and Maple. The G.T.R. as well as the Metropolitan Electric Railway and its connection with the Schomberg line provide a ready means of access for those wishing to make explorations in this region.

Glen Stuart (the Ames Property).-Take King Street car going east to Scarborough Beach Park. The southern entrance of Glen Stuart is opposite the Park.

Highland Creek.-Take King Street East cars to the Woodbine. Transfer to Kingston Road cars and go to terminus; then go down hill to the valley and walk up the valley.

High Park.-Most easily reached. by College Street cars, which enter Park.

Humber Valley.-Take the King West cars until ther turn, then the car to the Humber and walk northward; or take the Dundas cars to Keele Street and then the Lambton car to its terminus; walk westward to the Humber and south along the west bank.

Inglewood.-Take C.P.R to Inglewrood. The beginning of the Niagara escarpment is well marked here. 


\section{EXCURSIONS}

Lambton Mills. - Take suburban car at Keele Street, West Toronto, to its terminus; walk north or south along river. The west side is better wooded than the east.

Lorne Park.-Take radial to Port Credit and walk west about two miles to the Park. There is a wide strip of woodland here, and several small ponds neas the beach.

Meadowvale. - Take C.P.R. to Meadowvale. This is a favourite locality for artists and camera enthusiasts.

Milne's Swamp.-Take G.T.R. to Markham. This swamp is good botanical ground located a mile south-west of Markham village.

Mimico Creek.-Take the King Street cars to their terminus. Then the Port Credit cars as far as the creek; walk northward along the creek.

Mount Dennis.-Take the Weston route; leave the car at the Mount Dennis stop.

Niagara Glen.-Take a Niagara boat from the foot of Yonge Street, east side, to Queenston; then the car up the heights to Niagara Glen. Follow. the path down the steps to the glen.

Port Credit.-Take car of Toronto and York radial road at Sunnyside for Port Credit. The lakeside and the river valley offer much to the collector. 


\section{NATURAL HISTORY, TORONTO REGION}

Port Perry.-Take G.T.R. to Whitby; then transfer to the Port Perry line; leave train at Port Perry and go eastward until the marsh is reached.

Queenston Heights.-Take a Niagara boat from the foot of Yonge Street, east side of wharf, to Queenston, and walk or ride up the heights.

Scarborough Heights. - See at end of chapter on Geology.

Snelgrove.-Take C.P.R. to Snelgrove and walk northward through the village. About 11/2 miles beyond are to be found an extremely interesting series of peat bog ponds, around which are many plant rarities.

St. David's. - Take the boat to Queenston and walk up the heights as far as the road leading along the foot of the cliff; walk westward until the railway is reached; walk south along the track.

Swansea.-Take Queen Street car to Sunnyside and walk west; or take suburban car to bolt factory, then turn north. A short walk leads to the old belt line.

Toronto Island.-Ferry at foot of Bay Street to Island Park, Hanlan's Point or Ward's Island.

Uxbridge Swamp (Wick).-Take G.T.R. to Uxbridge; continue along the railroad about two miles. 


\section{EXCURSIONS}

This splendid swamp extends many miles towards Blackwater Junction.

Valleydon (Donlands). - Take Metropolitan line to Eglington Avenue; walk east two miles, crossing the Don and continuing about one-half mile. More easily reached by taking the C.P.R. to Valleydon and walking wouth-west.

Weston.-Take Dundas cars to Keele Street, i.e., the end of the Dundas line; transfer to Weston car; go nearly to the end of line, i.e., till the street leading to the bridge across the Humber is reached; cross the bridge and turn south along the river.

Wilcox Lake.-Take Metropolitan line to Currie's Crossing; walk east to eastern end of lake. Continuing east about half a mile leads to an interesting sphagnum swamp on north side of road. Turning to the north at eastern end of lake leads into a low-lying wooded tract. 


\section{N D E X.}

(Only the Orders and Families in the various lists are indexed.)

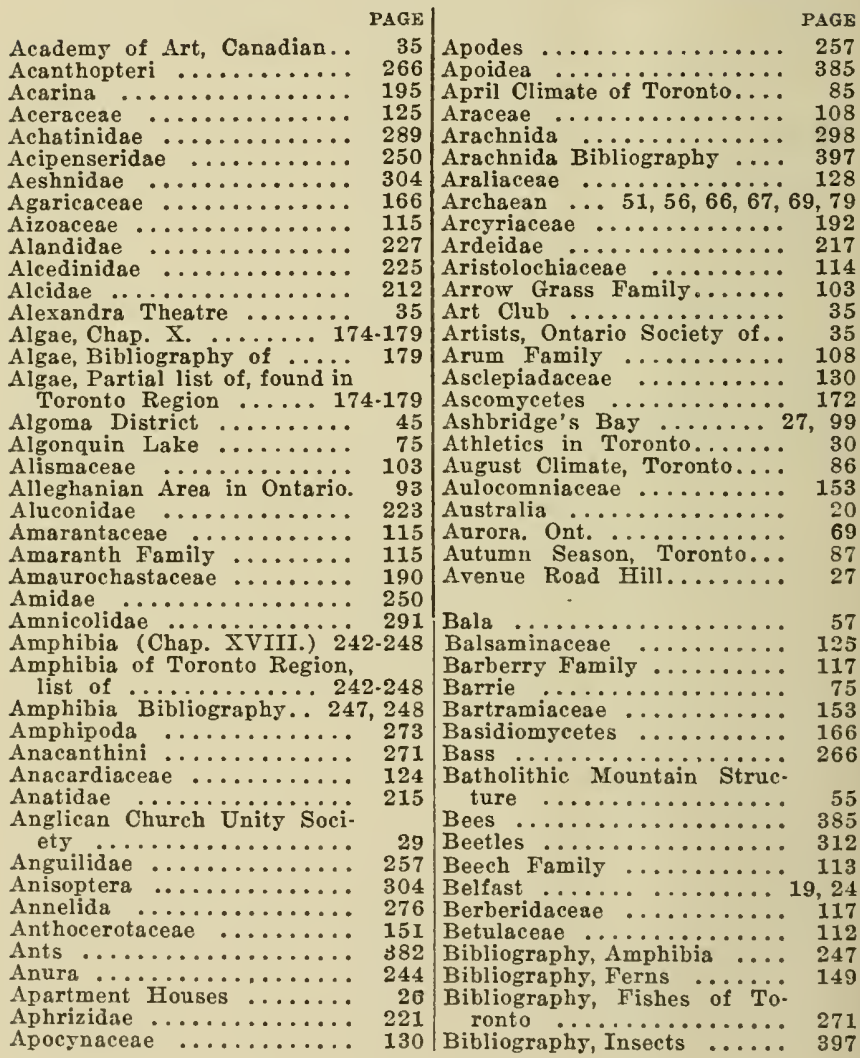


Bibliography, Reptiles

Bibliography, Slime Mouldz.

Bignonia Family

Bignoniaceae

Birch Family

Bird a (Chap. XVí.)

Birds, Bibliography

Birthwort Family

Bison

Bladder Nut Family........

Bladderwort Family

Bluebell Family ............

Bombycillidae ..........

Bombycoidea

Bond Lake $\cdots . . . . . .$.

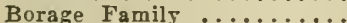

Boraginaceae

Botany, Department of.....

Botrydiaceae

Bouchette, Surreyor-General.

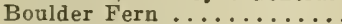

Boulton, D'Arcy

Bormanville

Bowfins

Bracken Fern

Brantford

British Columbia .........

Broom-rape Family .......

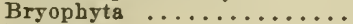

Bryaceae

Bryozos

Buckthorn Family .........

Buckwheat Family .......

Buller, Chas.

Burial Customs of the Missis: sagas

Burlington Bay

Bur-reed Family

Burwash Hall

Bushy Park

Buteonidae

Butterfies

Caddis-Flies

Callitrichaceae

Campanulaceae

Canadian Zone in Ontario...

Caprifoliaceae ............

Caprimulgidae ............

Carabidae

Carlyle

Carne $\ldots \ldots \ldots \ldots$

Carnegie Library .........

Carnivora ..............

Carolinian Area or Zone....

Carplike Fishes ..........

Carpa .................

Caryophyllaceae
PAGE

241

192

134

134

112

237

237

114

72

124

134

136

231

356

99

131

131

41

176

14

141

18

59

250

141

150

154

277

125

114

19

47

48

102

40

42

222

351

311

124

136

97

135

226

312

19

35

210

93

253

254

115
Casarant, Builder of Univer. sity Organ ............

Cashew Family ............. 124

Catarsqui ............ 46

Catfishes ............. 251

Cathartidas $\ldots \ldots \ldots \ldots \ldots \ldots 22$

Catostomidae .......... 253

Cat tail Family ......... 102

Celastraceae ........... 124

Centrarchidae .......... 266

Centre Island Park........ 30

Ceratophyllaceae ........ 116

Cestoda ............ 281

Crrthiidae ............ 235

Chaetophoraceae .......... 178

Chalcidoidea .......... 381

Chamsesiphonscese ...... 174

Chamberlain, Prof. A. F... 12, 49

Chamberlain, Prof. A. F., Indians who formerly in. habited or visited the site of Toronto (Chap. II.) ... 44-50

Characeae ............. 179

Charadriidae ........... 221

Charales ............ 179

Chenopodiaceae ......... 115

Chester, plan of ......... 15

Chestnut Zone of Mayr..... 93

Chicago ............. 12, 24

Chilopoda ............ 298

Chiropters ............ 209

Chlamydomonadaceae ..... 176

Choueguen (Oswego) ...... 13

Chroococeaceae ......... 174

Church Union ........... 29

Churches of Toronto..... 31-34

Circinariidae .......... 289

Cistaceae ............ 126

Cladocera ............... 275

Cladoniacese ........... 182

Cladophoraceae .......... 179

Clereland ............. 34

Climate of Toronto (Chap. IV.) $\quad \ldots \ldots \ldots \ldots \ldots \ldots 82-90$

Clinton ............. 64

Clubs of Toronto ........ 35

Clupeidae ............ 258

Cobourg ............. 58

Cockburn, Principal G. R. C. 20

Cockroaches ............ 299

Codfishes ............... 271

Coelenterata ............ 281

Colborne, Governor Sir John 18

Coleman, Prof. A. P... 12, 73, 160

Coleman, Prof. A. P., Geology of the Toronto Region

(Chap. III.) ........ 51.81

Coleochaetaceae ........ 178 
Dragonflies

$\ldots \ldots \ldots \ldots$

Collemaceae ........... 183

Collingwood ............ 59

Colymbidae $\ldots \ldots \ldots \ldots \ldots \ldots .212$

Columbidae ............

222

Compositae ............ 137

Composite Family ......... 137

Coniferous Swamp Trees....

Confervales .............

Conjugales .............

Convolvulaceae ...........

Convolvulus Family .......

Cook, Captain .............

Copepoda .............

Cornaceae ............

Cornwallis, Lord ............

Corvidae $\cdots \cdots \cdots \cdots$

Cosens, A., M.A., Ph.D., InToronto (Chap. XIYI.). 193.204

Cottidae ............. 271

Couchiching, Lake .......

Crane-flies .............

Crassulaceae ............

Credit River .......... 46.48

Crickets ............ 302

Crimean war ............

Crowfoot Family .........

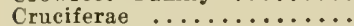

Crustacea ..............

Cuculidae .............

Cucurbitaceae ..........

Cynipoidea .............

Cyperaceae .............

Cyprinidae .............

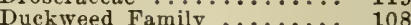

Dundalk .............. 52

Dundas .................. 72

Dundas Bay (Lake Iroquois) 74

Durantaye, M. de la ..... 13

Durham, Earl of ........ 18

"Dutch Chureh" ........ 71

Eaton Co., The T. ....... 25

Eaton, Mr. J. C. ......... 25

Edinburgh ............ 24

Education in Ontario .... 20-22

Eels .............. 257

Elaeagnaceae .......... 127

227

Elgin, Lord . ........ 19, 33

Elora $\ldots \ldots \ldots \ldots \ldots \ldots .6 \ldots \ldots$

Endodontidae ........... 290

Ephemerida ............ 303

Ephemerida Bibliography.... 399

Equisetaceae ........... 147

Ericaceae ............. 129

387 Erie, Lake ................ 14

119 Euphorbiaceae .......... 124

302 Excursions (Chap x yrif;

19

116

118

272

136

376

107

254

Decapoda

December Climate, Toronto. Denonville, Marquis de, quoted Dermatoptera

Dermatoptera, Bibliography...

Desmidiaceae ............

Detroit ................

Devonian ...... $51,53,65,66,68$

Dicranaceae ........... 152

Didymiaceae $\ldots \ldots \ldots \ldots \ldots \ldots .190$

Diplopoda..$\ldots \ldots \ldots \ldots \ldots .29$

Dipsacaceae ............ 136

Diptera .......... 197, 386

Diptera, Bibliography ...... 403

Dogbane Family .......... 130

Dogwood Family ............ 128

Dou $\ldots \ldots \ldots \ldots \ldots \ldots \ldots, 9$

Don Bay (old) $\ldots \ldots \ldots \ldots \ldots$. 74

Don Valley Exposures.. 60,70, 80

Dorosomidae .......... 258

Fagaceae ........... 113

Fairchild (Professor) ..... 73

Falconidae ........... 223

"Family Compact", ...... 18

Faull, Prof. J. H.-

The Algae (Chap. X.) . 174-179

Lichens (Chap. XI.). . 180.187

Mrscetozoa (Slime Moulds) Chap. XIY.) ...... 188-192

Feasts, Indian ........ 49

February Climate, Toronto.. 89

88 Ferns and Fern Allies (Chap.

12 VII.) .......... 141-149

Ferns of Credit Forks and Niagara ........... 141

Ferns of Igneous Rocks in Northern Ontario ....... 142

Ferns, Bibliography of.... 149

Festivals ............. 49

Figwort Family .......... 133

Fishes (Chap. XIX.) ...2 249-271

Fishes, Bibliography ..... 271

Flax Family ............ 123

Fleming, James $H$., Birds

(Chap. XVI.) …...... 212

Fleming, James H., Mammals (Chap. XV.) .......... 206

Flies .............. 389

Flora, Hudson Bay Drainage

Area...$\ldots \ldots \ldots$. 
Flora of Southern States in

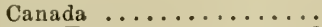

Flora, Toronto ........98, 101

Forest, Broad leaved trees and plants ...........

Forest, mixed broad-leavedneedle-leaved .........

Forest of Schimper ......

Forest of Warming ........

Forestry, Faculty of .....

Formicoidea ............

Fossils_in Black River Lime. stone

Fossils in Don Valley ....

Fossils in Trenton Rocks ..

Fossils in Utica and Colling. wood shales ........ 59,60

Fossils, Lorraine Shale.... . 60, 61

Fossils in Niagara and lower Silurian

Fossils in Guelph dolomite.

Fossils in Onondaga, Devonian .................. 65, 66

Frenchtown Massacre ...... 16

Fringillidae ........... 228

Frog's Bit Family ........ 103

Frontenac, Fort ..........

Fumariaceae ...........

Fumitory Family .........

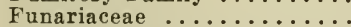

Fungi, Bibliography of .....

Fungi, Edible, near Toronto 161.163

Fungi, Partial list of, found near Toronto ........166-173

Fungi, Poisonous Species. 163-165

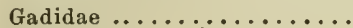

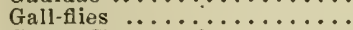

Galls, Classes of ........

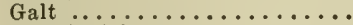

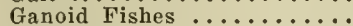

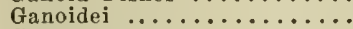

Gasteromycetes ..........

Gasteropoda Prosobranchiata.

Gasteropoda Pulmonata.. 289

Gasterosteidae ..........

Gaviidae ................

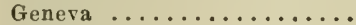

Gentian Family ..........

Gentianaceae ..............

Geology of the Toronto Region (Chap. III.)

Geological Excursions ......

Geological Formations, list of

Georgiaceae

Georgian Bay

Geraniaceae

Geraniaceae $\ldots \ldots \ldots \ldots \ldots$
271

376

193

64

250

250

172

288

290

265

212

35

130

130

51.81

79

53

152

66

123

123
PAGE

Germany $\ldots \ldots \ldots \ldots \ldots .7378$

Ginseng Family .......... 128

G!acial deposits in Toronto

Region ............6769

Glacial Lakes $\ldots \ldots \ldots \ldots \ldots 72,73$

Glacial Period ........... 53

Glasgow ............ 24

Guats ................... 388

Goldoni ............... 28

Goldthwaite (Professor) ... 75

Goosefoot Family ......... 115

Goulding, Champion Walker of the World .......... 30

Gourd Family ............. 136

Graham, G. H., Mosses and Liver Worts (Chap. VIII.)

150-157

Gramineae ............ 104

Grand River ........... 52

"Grange," The .......... 18

Grape Island ........... 46

Graphidaceae ........... 181

Grass Family ............ 104

Grasshoppers ........... 301

Grimmiaceae ................ 153

Ground-beetles ............ 312

Gruidae .............. 218

Guelph ........... 62, 64

Guild of Civic Art ....... 34

Gyalectaceae ............ 181

Half-gills ........... 265

Haloragidaceae ........... 127

Hamamelidaceae .......... 119

Hamilton ............ 74,81

Hanlan's Point ........ 28, 30

Hanlan, E. J. ......... 30

Haplomi ............... 263

Hart Hall ............ 39

Hart Massey Benefactions.. 39.40

Hartford Convention ...... 17

Head, Sir Francis ........ 18

Heath Family .......... 129

Helicidae .............. 289

Hemibranchii ............. 265

Hemiptera ........... 195, 306

Hemiptera, Bibliography.... 400

Herbaceous forms in Ontario, showing Southern Flora.. 92

Herrings ............. 258

Heterodermaceae ......... 190

Heteroptera ........... 309

High Park, Specimens of Slime Moulds found in... 189

Hiodantidae ........... 258

Hirudinea ............ 277

231 


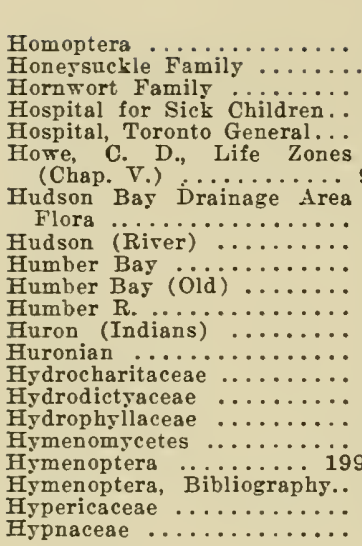

Ichneumonoidea

Indians of Toronto Region (Chap. II.) ...........

Indians, Bibliography of....

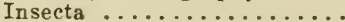

Insect Galls, Bibliography ..

Insect Galls of the vicinity of Toronto (Chap. XIII.). 193-204

Insectirora ........... 209

Insects and their Allies (Chap. XXII.) ......2 295-403

Insects, Bibliography ..... 397

Insects, Toronto collecting gronnds

Interglacial periods ......69-72

Invertebrates other than In. sects and Mollusks (Chap.

XX.) ..........272-287

Inrertebrates, etc., Biblio. graphy ........... 283-287

Iridaceae ........... 110

Iris Family .......... 110

Iroquois Beach ....... 74,81

Iroquois (Indians) . . . . 45,46

Iroquois, Lake ......... 73.75

Iroquois Shore

Island, Toronto ......... 28-30

Isoetaceae ............ 149

Isopoda ............. 274

Isospondylous Fishes ..... 258

Isospondyli ............ 258

Irey. T. J., Ferns and Fern

Allies (Chap. VII.)... 141.149
PAGE

Jesuits .............. 12

Jones, Res. Peter ........47, 50

Johnson, Sir Wm., quoted... 14

Juglandacease . . . . . . . . 112

Juncaceae ............. 109

Juncaginaceae ............ 103

Jungermanniacese ......... 151

July Climate, Toronto..... 86

June Climate, Toronto..... 86

Kennedy, Masor Warring... 24

Kentucky ..........11, 12, 16

Ketchum, Jesse .......... 34

Keys, Prof. D. R., Historical and Descriptive Sketch of
Toronto (Chap. I.).... 11.43

Killifishes ............. 265

King's College ......... 20-37

Kingston ........... 58

Knox College ......... 20,33

Labiatae .............. 132

Labrador ............. 63

Lake Ontario ........... 26

Lakeside Home for Sick Children .............. 29

Lambton Mills .........66, 80,81

Lampreys ............. 249

Langton, Thos., Mushrooms and other Fungi (Chap. IX.) ............ 158.173

Laniidae ............. 231

Laridae ............. 213

Lauracese ............ 118

Laurel Family ........... 118

Laurentian ........... 54

"Laurentian River" ..... 66

Laurier, Sir Wilfrid, quoted. 22

Lecanoraceae .......... 184

Lecideaceae ........... 181

Leguminosae .......... 122

Lemnaceae ............... 108

Lentibulariaceae ........ 134

Lepidoptera ........... 196, 351

Lepidoptera, Bibliography... 401

Leskeaceas ............. 154

Leucosporae ............. 166

Lewiston ............. 76

Libellulidae .............. 305

Lichens (Chap. XI.) ... 180-187

Lichens, List of, occurring in Toronto region ....... 181-187

Lichens, Bibliography of .... 187

"Lido," The .......... 28 Life Zones, America (Chap.

V.) .............. 91-99

Limacidae ........... 289 


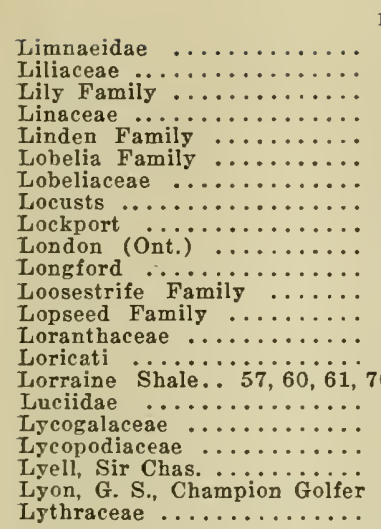

Macaulay, C. J.

Macdonald, Sir John A.....

Mackenzie, Prof. J. J. quoted $\ldots \ldots \ldots \ldots$ 174, 179

Mackenzie, Tim. Lyon .....

Macoun, Prof. John, quoted.

Madder Family ..........

Magnolia Family .........

Magnoliaceae ..........

Maitland, Governor Sir P...

Mallow Family ..........

Malraceae ..................

Mammals (Chap. XV.) .. 206-211

Mammals, Bibliography .... 211

Mammoth, remains found in Toronto

72

Manitoulin (Island) $\ldots \ldots 44,46$

Manufactures of Toronto.... 36

Maple Family ........... 125

March Climate, Toronto....

Marchantiaceae .........

Markham Township ......

Marsipobranchii

Iarsupialia

Massey-Treble, Mrs. ......

Mastodon

Mattawa

May Climate of Toronto....

Mayr, Chestnut Zone of ....

MeMaster Unirersity (Bap. tist)

MeMurrich, Prof. J. Playfair, Zoology (Chap. XIV.)...
290

109

109

126

136

136

299

64
75

58

135

114

271

263

191

148
76

30

127

Measuring-worms ........ 367

Menispermaceae $\ldots . \ldots \ldots . . .117$

Merriam, Transition Zone .. 93

Mesocarpacese.......... 176

Meteorological Table of Elements of Toronto, 1842$1911 \ldots \ldots \ldots \ldots \ldots$

Meteorological Observatory.

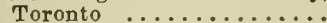

Meteorological Office .......

Ietzgeriaceae ..........

Mezereum Family .........

Michilimaquina ..........

Micropodidae ............

Midges ...............

Mignonette Family .......

Milkweed Family .........

Milkwort Family .........

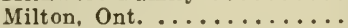

235

Mint Family $\ldots \ldots \ldots \ldots . . .132$

Mississaga, derivation of... 45

Mississagas, various names of 45

Mississauga, Fort ....... 44

Mississanga Avenue ....... 44

Mississauga River ....... 44-46

Mississauga Strait ....... 44

Mistletoe Family ......... 114

Mniotiltidae ........... 232

Mrohawk Valley .......... 73

Mollusea (Chap. XXI.).. 288.294

Mollusca, Bibliography .. 293, 294

Mollusea, Sources of List....288

Moodie, Mrs. .......... 49

Moonseed Family ......... 117

Mosquitoes ............. 388

Mosses and Liverworts (Chap. VIII.) ............ 150-157

Mosses and Liverworts: List of families and species growing within easy collecting distance of Toronto ............ 150-155

Mosses, Interglacial, of Toronto with notes ..... 155, 156

Mosses, Bibliography of.... 157

Motacillidae ........... 235

Moths .............. 356

Mud (Chemung) Lake...... 46

Museum, University ....... 41 Mushrooms and other Fungi (Chap. IX.) ....... 158-173

Mushroom Cultivation .. 165, 166

Mustard Family ......... 118 Mycetozos or Slime Moulds

205 (Chap. XII.) ...... 188.192 
Mycetozoa or Slime Moulds, List of, found in Toronto

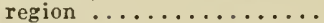

Myricaceae

189

112

Nash C. W., Fishes (Chap. XIX.) …......249.271

Najadaceae

102

Nematelminthes ..........

Nematognathi ...........

Neuroptera ............

Neuroptera, Bibliography ..

Nettle Family ...........

New York ..............

New England ...........

New Jersey ...........

Niagara

Niagara Falls ........ 75-78, 81

Niagara Formation ... 62-64,68

Niagara, Fort .......... 13

Niagara River . . . . . . . 52, 69, 81

Niagara Whirlpool ...... 72,77

Nightshade Family ....... 133

Nostocaceae ........... 175

November Climate, Toronto.

Nymphaeaceae .........

Oak Ridges ...........

Observatory, Toronto ......

O'Connor, champion oarsman of the world ..........

October Climate of Toronto.

Odonata ........... 303, 399

Odontophoridae ......... 221

Oedogoniaceae ........... 178

Ojibwa (or Chippewa) ... 45,50

old Fort (at Toronto)...... 16

Oleaceae .............. 130

Oleaster Family ......... 127

Oligochaeta $\ldots \ldots \ldots \ldots \ldots .276$

Olive Family ........... 130

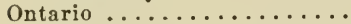

Ontario, Flora of Southern

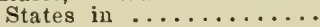

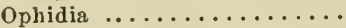

Ophioglossaceae ........

Orchid Family ..........

Orchidaceae ............

Orobanchaceae ...........

Ordovician .......55 53,56-61, 67

Ordovician, Subdivisions....

Orpine Family ..........

Orthoptera .............

Orthoptera, Bibliography....

Oscillatoriaceae ..........

Oshawa

... 59

Osgoode Hall $\ldots \ldots \ldots$ 15, 24, 25

Osmundaceae
PAGE

Ostracoda $\ldots \ldots \ldots \ldots \ldots$
Oswego (Choneguen) $\ldots \ldots .$.

Onagraceae ........... 127

Oxalidaceae ........... 123

Palaeozoic ..... 52-54, 56-67, 69

Papaveraceae .......... 118

Papilionoidea .......... 351

Parasitica ............... 306

Paridae ............. 236

Parks (Professor) ...... 60,62

Parliament Buildings ..... 15-17

Parmeliaceae ........... 185.

Parry Sound .......... 55

Parsley Family ......... 128

Pelecanidae .......... 214

Pellatt, Sir Henry ........ 27

Peltigeraceae ........... 183

Pelycypoda .......... 292

Peneplain ........... 56

"Pennsylvania Dutch" ... 19

Perches (fish) .......... 268

Perchlike Fishes ........ 266

Percidae .............. 268

Percoidea ............... 266

Pertusariaceae ........... 184

Petromyzidae ........... 249

Phalacrocorvacidae ....... 214

Phalaropidae ............ 218

Phanerogamia ........... 101

Philomycidae .......... 290

Phrymaceae ........... 135

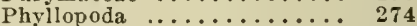

Physidae ............. 291

Plysciaceae ........... 186

Picidae .............. 225

Pickerel-weed Family ...... 109

Picquet, Abbé .......... 13

Piersol, Prof. W. H., Am.

phibia (Chap. XVIII.). 242-248

Pike (Fishes) ........... 263

Pike, General .......... 16, 17

Pinaceae .............. 101

Pine Area ............. 94

Pine Family ............ 101

Pink Family ............ 115

Pitcher Plant Family....... 119

Plane Tree Family ....... 120

Plantaginaceae ........... 135

Plantain Family ......... 135

Platanaceae .................... 120

Platyhelminthes ......... 279

Plecoptera ........... 302

Plecoptera, Bibliography ... 398

Plectognathi ........... 271

Plectognathous Fishes ..... 271

Plectospondyli .......... 253

Pleistocene ... $51-53,66-78,80,81$ 
PAGE

Pliocene

54,66

Poeciliidae ............ 265

Polemoniaceae ...........

Polemonium Family ......

Polygalaceae ............

Polygonaceae ............

Polypodiaceae ...........

Polyporeaceac ..........

Polytrichaceae ...........

Pond Weed Family ........

Pontederiaceae

Poplar Area .............

Population of Canada......

Poppy Family ............

Porifera

Port Credit ..........660,61

Port Hope .............

Portulaca ceae ............

Power, Bishop ..........

Primrose Family .........

Primulaceae

131

131

123

114

142

170

152

102

109

94

23

118

281

58

116

19

129

129

214

Procellariidae ..........

Proctor, General ...........

Protococcales

Protozoa

16

177

282

122

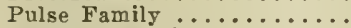

Purslane Family .........

Pupidae

Pyrenulaceae

116

289

187

Queenston Heights

76

Queenston red shale.....661,68

Quinte (Kenti)

Railways, Earliest Toronto..

Rainfall, Summer Toronto...

Rallidae

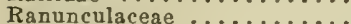

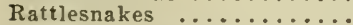

Recurvirostridae $\ldots \ldots \ldots . . . . .$.

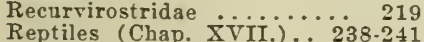

Reptiles, Bibliography......

Resedaceae ...........

Reticulariaceae ..........

Rhamnaceae ............

Ricciaceae ..............

Richmond, Duke of.......

Rice Lake .............

Richmond marine beds......

Rirulariaceae ...........

Robertson, A. D., Mollusca

(Chap. XXI.) ....... 288-294

Robertson, Mr. John Ross.. 29, 35

Robinson, Sir John .......

Roches Moutonnees .......

Rochester

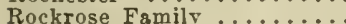

Rodentia

19

87

218

116

238

241

119

191

125

150

18

46

61

175
Rogers, Major, quoted .....

Rondeau Park ...........

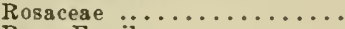

Rose Family

Rosedale $\ldots \ldots \ldots \ldots \ldots \ldots 16,41$

Ross, General ........... 17

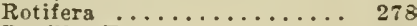

Rouille, Fort ........... 13

Rubiacese ............. 135

Rue Family ............ 123

Rush Family .......... 109

Rutaceae .............. 123

Ryerson, Dr. Geo. ........ 47

R-erson, Dr., Superintendent of Education

St. John's-wort Family ....

126

St. Catharines ......... 74

St. Lawrence ........... 73

St. Michael's College ..... 21

Salicaceae .................. 111

Salina ............. 62,64

Salmon ............. 259

Salmonidae ........... 259

Salt deposits ............. 65

Sandalwood Family ........ 114

Santalaceae ............. 114

Sapindaceae ............ 125

Sarraceniaceae .......... 119

Saturnoidea ............ 355

Sawflies ............. 375

Saxifrage Family ........ 119

Saxifragaceae ........... 119

Scadding, Dr. Chas., quoted. 12, 33

Scarborough Beach ....... 27

Scarborough Bluffs ....... 99

Scarborough Heights

Scenedesmacese ........ 177

Schimper Forest ......... 93

Schizopoda ............ 273

Scholes, John .......... 30

Scholes, Lou, winner of Diamond Sculls .........

Schooleraft, quoted .......

Scolopacidae .......... 219

Scoresby, Arctic Explorer... 33

Scott, Principal Wm., Seed Plants (Chap. VT.).... 100-140 Scott, Principal Wm., Flora of Ontario

140

Scrimgeour, W. G., author of IS. Thesis on Slime

Moulds ............. 188

69 Scrophulariaceae ......... 133

64 Scugog, Lake ...... 46, 47, 50

126 Sculpins .............. 271

207 Scytonemaceae ............. 175 
Seasons, Toronto ........

Sedge Family
Seed Plants, Toronto and

PAGE vicinity (Chap. VI.) .. 100-140

Seed Plants, Bibliography of, in Toronto region .......

Seignelay, M. de .........

Selaginellaceae

Selwyn, Bishop of New Zea. land

September Climate, Toronto.

Serranidae

Seven Years' War ........

Shaler, N. S. .............

Silurian ......... $53,62-63,81$

Silurian, Prof. Parks' Classification of ...........

Siluridae.$\ldots \ldots \ldots \ldots \ldots$.

Simcoe, Lake ...........

Simcoe, Major-General

14,33 (note), 35

Simcoe Park .................

Siphonales ............ 178

Siphonocladiales ........ 179

Sittidae ........... 235

Smith, Prof. Goldwin .....

Snakes of Toronto Region..

Snelgrove (near Brampton).

Snowfall, Toronto ........

Soapherry Family .........

Soils of the Toronto Region 78,79

Solanaceae ............. 133

Somers, Frank .......... 24

Sparganiaceae .......... 102

Spencer, Dr, quoted. $66,73,76,77$

Sphaeriidae ........... 292

Sphagnaceae ........... 152

Sphingoidea ...........

Spring Season, Toronto....

Spurge Family ..........

Staff Tree Family .........

Staphyleaceae ..........

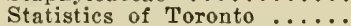

Strachan, Bishop ........

Stemonitaceae

Stercorariidae

Stereocaulaceae ...........

Sticklebacks ...........

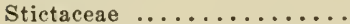

Strigidae

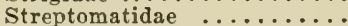

Stupart, R. F., Climate of Toronto (Chap. IV.)....

Succincidae

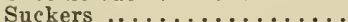

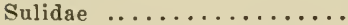

Summer Season, Toronto....
Sundew Family ..........

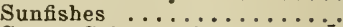

Sweet Gale Family .........

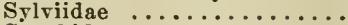

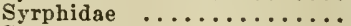

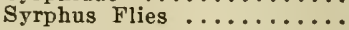

Tanagridae ............. 231

Taxaceae .............. 101

Taylor, Mr. F. B. ..... 67, 76

86 Teasel Family ........... 136

270 Teleostii .............. 251

13 Teloschistaceae .......... 185

Temperature, maximum extremes in Toronto ......

Temperature, mean annual, at

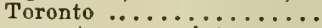

'l'emperature, winter ex. tremes, Toronto ........

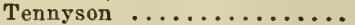

Tent-Caterpillar Family ....

Tenthredinoidea $\ldots \ldots \ldots$.

Testudinat $\ldots . . . . . . .375$

Thames (River), Ontario... 52

The Ward (of St. John)... 24, 25

Thornhill ............ 56

Thousand Islands ....... 57

238 Thymelaeaceae ......... 127

180 Tiliaceae ................ 126

89 Timmiaceae ............ 153

25 Tindall, W. B., quoted....... 175 Toronto, Climate of (Chap.

IV.) $\ldots \ldots \ldots \ldots \ldots \ldots 82.90$

Toronto, Flora ........998, 101

Toronto Formation (interglacial beds) ...........

Toronto Island ............ 80

Toronto rainfall, summer.... 87

Toronto Seasons ......... 84

Toronto Seed Plants ....... 100

Toronto Snowfall ........ 89

Toronto Temperature, mean annual

Toronto Temperature, extremes in summer and winter .............. 86, 88

Toronto, Table, monthly mean of meteorological elements,

265 Toronto Vegetation .......... 98

223 Tortulaceae ............. 153

292 Touch-me-not Family ..... 125

Transition Zone of Merriam. 93

82.90 Trees of Toronto ........ 42

290 Trematoda ............. 279

253 Trent Valley ......... 75, 76

214 Trenton .......... 58,69,74

86 Trichiacea $\ldots \ldots \ldots \ldots \ldots . . . .191$ 


\section{INDEX}

Trichoptera

311

Trichoptera, Bibliography... Trinity College (Anglican)

Trochilidae $20,21,40$

226

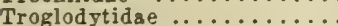

Trout

235

Tubulinacea

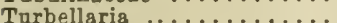

Turdidae

Tyan

Trannidae

Ulotricales

261

190

279

236

102

226

Ulotrichacese ...........

178

Umbelliferae .............

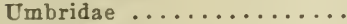

Ungulata

Ungulata $\cdots \ldots \ldots \ldots \ldots \ldots$

U. E. Loyalists ........... 11, 14

University College .... 11, 21, 38

University of Toronto $11,20,21,26,37.41$

Upper Canada .......... 11, 14

Upper Cansda College.. 18, 20,31

Urodela

242

Urticaceae ............. 113

Valvatidae

Vancheriacese

Vegetation, Toronto .......

Venice ..............

Ferbenacese ............

Vervain Family

Tespoides

Victoria College (Mrethodist)

178

98

28

132

132

382

$21,39,40$

Vine Family .......... 125

Violaceae

126

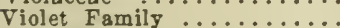

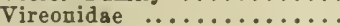

Virginia

Vitaceae

Viviparidae

126

11

125

289
Volvocaceae ................ 177

Tolvocales ............... 176

Walker, E. M., Insects and Their Allies (Chap. XXII.)

Walmer Road .................. 27

Walnut Family ............. 112

Warming Forest .......... 93

Warner, Chas. Dudley, quoted 28

Washago ........... 54, 57

Washington (City) ...... 17

Tasps ............... 382

Water Lily Family ........ 116

Water Milfoil Family ..... 127

Water Starwort Family .... 124

Waterdown .............. 61

Taterleaf Family .......... 131

Water-plantain Family ..... 103

White, Jas., quoted....... 180

Williams, J. B., Reptiles

(Chap. XVIr.) ......2238-241

Willow Family .......... 111

Winder, D. K., author of pam. phlet on Fungi........ 160

Winter Season, Toronto..... 88

Wisconsin ice sheet ....6 68, 73

Witch-hazel Family ...... 120

Wood Sorre] Family ....... 123

Wycliffe College......... 21

Wykham Hall .......... 25

Yacht Club Royal Cansdian. 30

Yew Family ............ 101

Yonge Street named after Sir

Geo. Yonge ........... 14

York (now Toronto). 14, 16, 18, 34

Y.M.C.A. ......... 31

232 Zoology, by Prof. J. Playfair

Mc Hurrich (Chap. XIV.). 205
Zonitidae ................ 289

Zygnemaceae ............ 176 
288216 


